\title{
Seduepb
}

\section{Nova leitura crítica de Jorge Amado}

\author{
Sudha Swarnakar \\ Ediliane Lopes Leite de Figueiredo \\ Patricia Gomes Germano \\ (Orgs.)
}

SWARNAKAR, S., FIGUEIREDO, ELL., and GERMANO, PG., orgs. Nova leitura crítica de Jorge Amado [online]. Campina Grande: EDUEPB, 2014, 319 p. ISBN 978-85-7879-328-9. Available from SciELO Books $<$ http://books.scielo.org $>$.

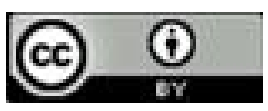

All the contents of this work, except where otherwise noted, is licensed under a Creative Commons Attribution $\underline{4.0 \text { International license. }}$

Todo o conteúdo deste trabalho, exceto quando houver ressalva, é publicado sob a licença Creative Commons Atribição 4.0.

Todo el contenido de esta obra, excepto donde se indique lo contrario, está bajo licencia de la licencia $\underline{\text { Creative }}$ Commons Reconocimento 4.0. 


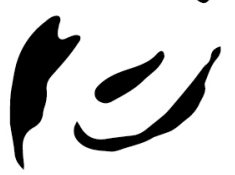

Nova leitura crítica de Jorge Amedo
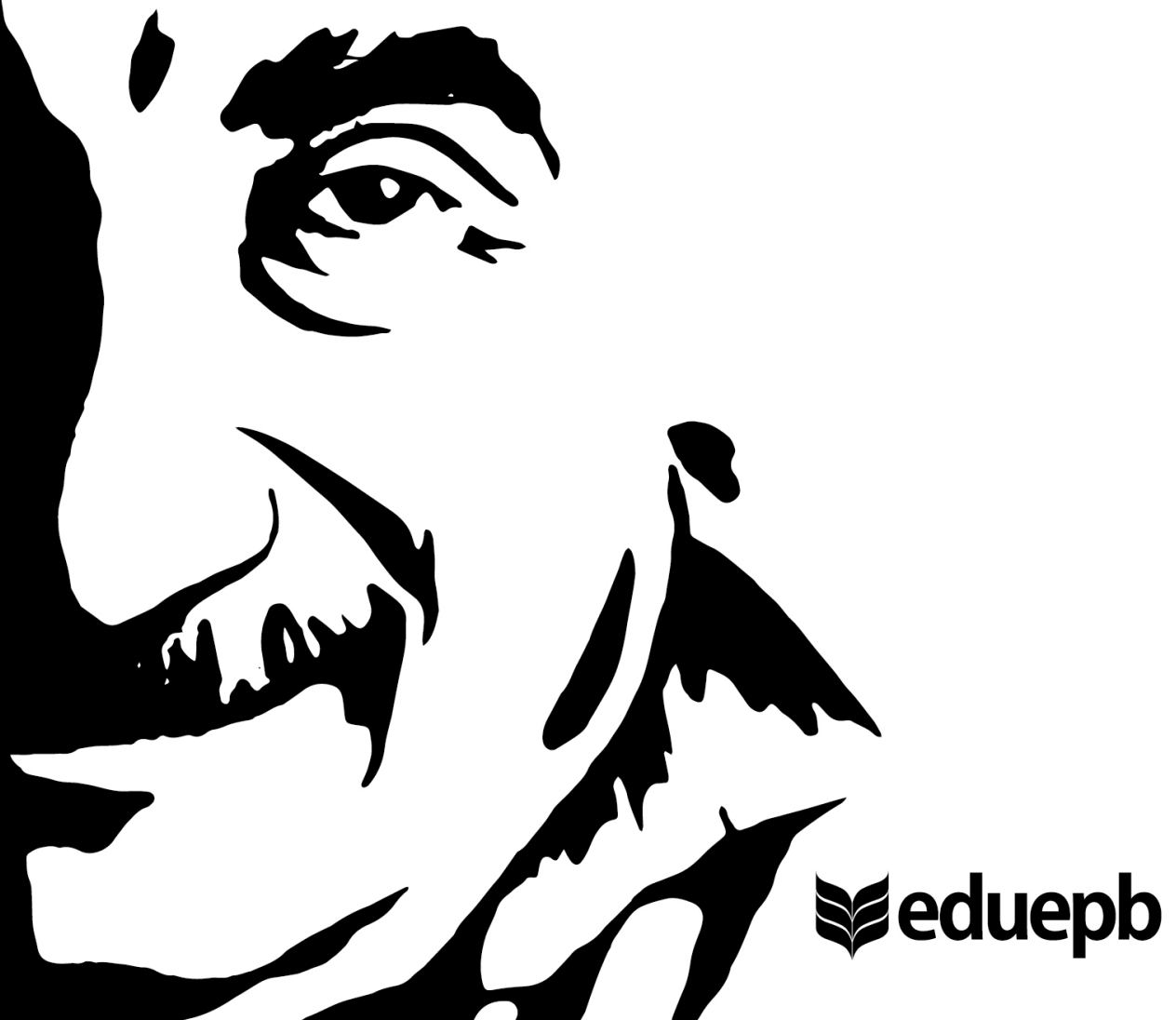
Nova leitura critica de Jorge Amado 
Sudha Swarnakar

Ediliane Lopes Leite de Figueiredo

Patricia Gomes Germano

(Organizadoras)

\section{Nova leitura critica de Jorge Amado}

\section{$\$$ eduepb}

Campina Grande - PB

2014 
Copyright $($ C) EDUEPB

A reprodução não-autorizada desta publicação, por qualquer meio, seja total ou parcial, constitui violação da Lei $n^{\circ}$ 9.610/98.

A EDUEPB segue o acordo ortográfico da Língua Portuguesa de 1990, em vigor no Brasil, desde 2009.

Editora da Universidade Estadual da Paraíba

Cidoval Morais de Sousa $\mid$ Diretor

Arão de Azevêdo Souza | Editor Assistente de projetos visuais

Antonio Roberto F. da Costa | Editor Assistente de Conteúdo

\section{Design Gráfico}

Erick Ferreira Cabral

Jefferson Ricardo Lima Araujo Nunes

Lediana Costa

Leonardo Ramos Araujo

Comercialização

Álisson Albuquerque Egito

Divulgação

Zoraide Barbosa de Oliveira Pereira

Revisão Linguística

Elizete Amaral de Medeiros

Normalização Técnica

Jane Pompilo dos Santos

\section{Depósito legal na Biblioteca Nacional, conforme Lei $n^{\circ} 10.994$, de 14 de dezembro de 2004}

FICHA CATALOGRÁFICA ELABORADA PELA BIBLIOTECA CENTRAL - UEPB

Nova leitura critica de Jorge Amado.

Sudha Swarnakar; Ediliane Lopes Leite de Figueiredo; Patrícia Gomes Germano (Organizadores). - Campina Grande: EDUEPB, 2014. $318 \mathrm{p}$.

ISBN 978-85-7879-178-0

1. Jorge Amado. 2. Criticas. 3. Análise textual. I. AMADO, Jorge. II. Título

21. ed. CDD 


\section{Sumário}

Apresentação . . . . . . . . . . . . . . . . . .9

Organizadoras

Jorge, Internacionalmente Amado . . . . . . . . . 15

Sudha Swarnakar

Os milagres da Tenda: uma leitura da mestiçagem em

Jorge Amado. . . . . . . . . . . . . . . . . . . 35

Humberto Luiz Lima de Oliveira

Do Modernismo Paulista ao Regionalismo do

Nordeste.......................61

Cid Seixas FragaFilho

Her tongue is tied not her eyes: Amado's experiment with non verbal language in Tereza Batista Cansada de Guerra..........................73

Sudha Swarnakar

Direito e literatura: Tereza Batista Cansada de Guerra e a atual legislação brasileira protetiva da mulher . . . 87 Lucira Freire Monteiro

Beecher Stowe e Jorge Amado: Uma Visão Jusliterária da Injustiça Social . . . . . . . . . . . . . . . 115 Ediliane Lopes Leite de Figueiredo 
Fronteiras, Travessias e Passagens... O Entre-Lugar do Maravilhoso em O Sumiço da Santa de Jorge Amado. . 139 Patrícia Gomes Germano

A Incidência do Fantástico em $\boldsymbol{A}$ Morte e a Morte de Quincas Berro D’água e Dona Flor e Seus Dois Maridos............................ 167 Marilene Carlos do Vale Melo

Anarquia e Humor: a representação do povo em sua subversão dos valores dominantes . . . . . . . . . 191 Luiz, Felipe de Queiroga Aguiar Leite

Será um romance proletário?............. 213 Geralda Medeiros Nóbrega

Entre Bahias e Musseques: O Diálogo Além Mar de Jorge Amado e Luandino Vieira . . . . . . . . . . 231 Lilian Barbosa e Sueli Meira Liebig

O Querer-dizer de Jorge Amado no viés popular . . . 253 Maria Divanira de Lima Arcoverde

A Morte e a Morte de Quincas Berro D'água:

Carnavalização e Processos Estilísticos . . . . . . . 271 Nefatalin Gonçalves Neto 
(Re)Descobertas e Indefinições - entre a representação, a sub-representação, faroeste e orixás: uma breve leitura de Terras do sem fim, de Jorge Amado . . . . 293 Auricélio Ferreira de Sonza

Os Autores ........................ 321 


\section{Apresentação}

Não quero erguer monumento nem posar para a história cavalgando a glória. Quero apenas contar algumas coisas, umas divertidas, outras melancólicas, iguais à vida. A vida, ai, quão breve navegação de cabotagem.

(JORGE AMADO)

Em 10 de agosto de 1912, o Brasil acolheu no fértil solo baiano o "menino grapiúna", mais tarde conhecido e reconhecido mundialmente como o grande contador de histórias: Jorge Amado. No ano de 2012, o Brasil celebrou o centenário do nosso grande e internacionalmente Amado "Jorge". As comemorações aconteceram das mais variadas formas, passando pelo ecletismo dos suportes, pela multiplicidade de expressões, assim como ele preconizava em seus textos, a poética da diversidade. Congressos, simpósios, colóquios, inúmeros concursos, publicações, artigos, palestras, produção de TV, novela, gincanas, peças teatrais, desfiles carnavalescos, entre tantas homenagens.

Amado é o escritor brasileiro mais traduzido e a figura literária que moldou a recepção da literatura brasileira no mundo. Por um lado, ele é o escritor mais popular do Brasil dentro e fora do Brasil, mas por outro lado ele também é o escritor brasileiro mais polêmico. Portanto, sua recepção é 
mista. Para alguns ele é uma fonte fascinante de informações sobre a sociedade brasileira, um embaixador da cultura brasileira, mas para outros ele é um populista com a agenda política, um escritor cujo texto apresenta abundância do sexual e sensual como ele retrata mulher. Seja qual for a posição, não se pode negar que, antes de Clarice Lispector, ele foi o único escritor brasileiro que era conhecido e discutido nos meios acadêmicos fora do Brasil. Seus livros são lidos por pessoas de mais de cinquenta países. Seu romance, Gabriela, Cravo e Canela (Traduzido em Inglês por James L. Taylor e William L. Grossman) foi listado como um dos melhores de vinte e cinco romances publicados nos Estados Unidos em 1962 ( Brower et al. , 2001 , p.1).

Esta publicação, organizada por Sudha Swarnakar, Ediliane Figueiredo Lopes e Patrícia Gomes Germano, é resultado de trabalhos produzidos para mais uma celebração do centenário do Jorge Amado "Jorge, Internacionalmente Amado" na cidade de Campina Grande. O evento foi promovido pela Associação Brasileira de Estudos Comparativos ABRAEC, o Curso de Pós-Graduação em Letras - Literatura e Interculturalidade e o Gt Estudos Comparativos Interculturais do Departamento de Letras da Universidade Estadual da Paraíba.

Uma profusão de possibilidades reside no texto deste escritor, cujo aspecto fundante é mostrar a capacidade performática do constructo literário associada à ampla aceitação junto aos leitores. Todo esse potencial de literalidade 
nos levou a questionar o que atrai um grande número de pesquisadores das mais diversas áreas a se debruçar sobre a obra de Jorge Amado, já de fundo tão conhecida e compartilhada por um grande público que gosta de amar ou odiar, criticar ou apreciar seus romances, o que torna o escritor baiano alvo constante de traduções diversas. O próprio Amado, referindose ao seu acervo literário, assim se pronunciou: "Publico esses rascunhos pensando que, talvez, quem sabe, poderão dar ideia do como e do porque" não é difícil perceber que este menino de Itabuna, de Ilhéus, da Bahia diz algo a mais em suas obras, algo que as aproxima do povo. Sendo simples, é gentil, sendo modesto, nunca deixou de ser firme e comprometido e, apesar de assumir em alguns momentos de sua empolgante biografia, a identidade de um "Jorge Vermelho" é um brasileiro, um baiano; é, sobretudo, um escritor nosso que provoca tradutores de mais de 50 países e os mais variados meios artísticos a realizar leituras e traduções de suas obras, conduzindo as inúmeras manifestações culturais brasileiras por trânsitos diversos.

O livro reúne ensaios de pesquisadores brasileiros de renome e jovens que apresentam diferentes olhares sobre um autor que se mostra aberto às mais diversas análises e interpretações. Cid Seixas Fraga Filho, discutindo o Modernismo Paulista e o Regionalismo do Nordeste, apresenta o quadro panorâmico do pensamento artístico e social do Século XX e mostra como os autores como Jorge Amado e outros jovens intelectuais da província inserem a Bahia e a novo movimento. 
Humberto Luiz Lima de Oliveira discute o modo emblemático da Tenda dos milagres, romance que sintetizaria a teoria da formação da cultura brasileira que o escritor baiano vê como inteiramente mestiça.

No eixo concernente à direito dois artigos se referem as relações entre direito e obra de Jorge Amado. Lucira Freire Monteiro propõe traçar a relação entre Direito na Literatura, uma revisão legal da realidade esboçada, no romance Tereza Batista, Cansada de Guerra. Ainda em torno de direito, adotando a perspectiva comparativa que privilegia as relações entre literatura e direito, Ediliane Lopes Leite de Figueiredo investiga as questões referentes à opressão, à marginalidade, ao preconceito, fatores desencadeadores da injustiça social que remetem direita ou indiretamente para aspectos jusliterária nas obras Uncle Tom's Cabin de H. Beech Stowe e Capitães de Areia da autoria de Jorge Amado.

Partindo de reflexões sobre a Teoria da Representação Social Auricélio Ferreira de Souza propõe uma leitura da obra Terras do sem fim, de Jorge Amado com o intuito de problematizar a questão da representação e da sub-representação social em seus personagens.

Comparando Jorge Amado e José Luandino Vieira, Lilian Barbosa e Sueli Meira Liebig contestam que as obras de Jorge Amado como Capitães de Areia, e de Vieira A Cidade e a Infância, dialogam e convergem entre si. As autoras salientam pontos comuns entre dois escritores promovendo a visualização da realidade social de sua cultura e região através sua escrita. 
Homenageando Amado, Sudha Swarnakar faz um breve relato da vida e obras de Jorge Amado discutindo a adaptação, tradução e recepção universal de obras de Jorge Amado justificando o titulo "Jorge, Internacionalmente Amado".

Traçando a passagem social, Geralda Medeiros Nóbrega destaca a trajetória de Jorge Amado enquanto escritor. Analisando sua obra Cacau a autora contesta que o mundo amadiano é voltado para apresentar a vida dos que estão à margem, excluídos do progresso.

A Morte e a Morte de Quincas Berro D'água provoca as autoras Marilene Carlos do Vale Melo e Nefatalin Gonçalves Neto. O insólito ressaltado pelo discurso fantástico é o foco do artigo de Marilene Carlos do Vale Melo. Nefatalin Gonçalves Neto tenta resgatar esta obra para o, "harém dos escritos qualitativos de Jorge Amado" por meio da análise de seu viés carnavalizado.

Com enfoque em seu papel de subversão dos valores dominantes, partindo de três tópicos: a anarquia, o humor e a mestiçagem, o artigo de Luiz Felipe de Queiroga Aguiar Leite discute a representação do povo na obra de Jorge Amado.

Em O sumiço da Santa Patrícia Gomes Germano tenta destacar a representação do maravilhoso, o reencenar dos mitos e das travessias, a quebra de fronteiras entre a realidade consolidada e o insólito sobrenatural.

Dois artigos se referem o discurso e linguagem na obra amadiana. Maria Divanira de Lima Arcoverde mostra como "o ícone da literatura baiana" ultrapassa os limites dos 
interstícios discursivos e Sudha Swarnakar mostra a riqueza da linguagem desse escritor baiano quando apresenta o discurso silencioso da Tereza Batista e uso do outros meios linguísticos por essa mulher "subalterna".

Tirará maior proveito deste livro o leitor familiarizado com a obra de Amado seja o livro ou uma adaptação para cinema ou T.V., já que este não é uma introdução à leitura dos textos amadianos e sim uma fonte que apresenta novas abordagens contribuindo com estudos críticos das obras do Amado.

Organizadoras 


\title{
Jorge, Internacionalmente Amado
}

Sudha Swarnakar

\author{
"É um paradoxo, mas ele conseguiu trans- \\ formar o regional em universal."
}

(Bruno Barreto)

Bruno Barreto's words call our attention to the universality of Amado's writing that combines well to the thematic title of the Centenary Celebration of Jorge Amado "JORGE, INTERNACIONALMENTE AMADO"' which I select as the title of this essay. Proud and pleased, I see how this event gathered people from all sort; academic, researchers, students, dramatists and general public. This multiplicity of group shows on one hand the popularity Amado enjoyed with his multiple identities; writer, journalist, historian, communist party leader, young rebel, member of Academia Brasileira de Letras etc., and on other hand, how this multiple identity could attract people from different opinion and liking.

Fifty years ago, it would have been unimaginable to talk about Amado in such an open way. Celebrating Centenary of Jorge Amado, today, I recall Claude Guméry-Emery who said:

Hoje é fácil elogiar Jorge Amado, mas não se deve esquecer que em outros tempos isso levaria à cadeia, da mesma maneira como o escritor 
baiano foi parar na prisão pelas idéias que sempre defendeu, e que seus livros foram queimados em praça pública, em auto de fé, como se o fogo queimasse as idéias. (p.74) ${ }^{2}$

The new generation of Brazil has no idea that similar to other leftwing writers, both in Brazil and in other parts of world great writers like Jorge Amado paid a heavy price for their political affinity. ${ }^{3}$ During my interview with Jorge Amado when I expressed my desire to see his manuscripts and letters, his whole expression was suddenly clouded by the extremes of emotion as it took him back to his painful past. He said, "o comunista não tem passado minha filha! Minhas cartas, meus livros, todos foram queimados aqui na praça..."

The political persecution also contaminated Brazilian literary opinion. It is not hard to find those who look at him with certain reserve or even scorn. When I was going to England for my doctorate, a colleague of mine, who was professor of Brazilian literature, asked me about my research topic. When I named Jorge Amado, along with other English and American writers, he did not seem content and said "Porque Jorge Amado?" It was my initiation in Brazilian literary world. I had no notion about the reception of Jorge Amado, and also had not known much about this Bahian writer, so I was astonished at the question yet I answered, questioning "Why not Jorge Amado? Today I may use same words but in 
a defying or sarcastic tone "Why not HE?"

According to Eduardo de Assis Duarte Jorge was little discussed by Brazilian critics because they were trained in modernism so they created a resistance to popular literature produced by writers like Jorge Amado. ${ }^{5}$ But Anco Márcio Tenório Vieira, comes close to my opinion as he says "foram quase inexistentes as tentativas de compreender a obra de Jorge Amado na academia." 6

I have dedicated a big part of my research, apart from the doctoral thesis, to his writings and presented Amado to Australians, Canadians, Americans, English and also to Portuguese and Brazilian audience in conferences and discussion panels talking and publishing papers on themes and topics related to Jorge Amado. I confess that I am an admirer of Amado. As a constant reader of his works, with each reading I discover a fascinating world created by stories narrated in a language which does not discourage his readers to enter in the depth of his writing. His humor as well as his satire is so subtle that a reader does not need special command of Portuguese language to understand it. In his writing, the oral and also the non grammatical forms of Portuguese are intermingled so well that the reader does not even note them. His famous character Gabriela’s "Queiro não", "Gosto não" instead of damaging the linguistic quality of text, enhance it as it brings the lyrical beauty to his text.

My reading of Amado has been bit diverted from other critics as I try to present the "lesser known Amado"; 
Amado who is "feminist" as he raises purely female questions such as abortion, rape, female exploitation and discrimination and marriage as any of female writers, Amado whose heroes and heroines are the marginalized or socially excluded, Amado who condemns the use of plastic surgery for beautification, Amado who is an eco-critic as early as 1940 as he talks of the misuse of water and burning of the forests. In a way it is an unbiased reading of these multiple faces of Amado, that presents him as a great Brazilian writer with his humanity and sympathy for marginalized and subalterns one of the reasons for his universal appreciation. According to the updated dictionary by Paulo Tavares Amado's world is crowded with approximately 5000 characters. It is a fantastic world where we find not only imaginary characters but also real people and some of them are still alive. ${ }^{7}$

During my research years, I could see that the writer, who in part, received scorn and coldness of some literary critics in Brazil, was read and admired both by the socialist countries like Italy, Germany, Russia, Hungry and also by capitalist countries like France, United States and England. The critical tone, specifically in Russia, France, Italy and United States was of praise and admiration. The Italian Feminists admirers of Amado decided to rename their "Italian Feminist Club" and since 1977 it is known as, "Tereza Batista Home." One of the reasons behind such universal acceptance of his writing can be explained through Amado himself as in his interview to VEJA (1969, p. 4) he explains: 
Isto se deve ao fato de que busquei ser sempre ser um escritor voltado para os interêsses, os problemas, a realidade brasileira, dando à minha literatura um caráter nacional, além do caráter social que a marca e preside. Sou um escritor brasileiro, não um papel carbono da última moda da Europa ou dos Estado Unidos. A isso deve o interêsse despertado por meus livros, suas traduções e as tiragens dessas traduções. O que toca, atinge e merece a atenção dos leitores estrangeiros é o Brasil, seu chão, seus problemas, sua vida, sua côr, seu ritmo, seu povo. ${ }^{9}$

In Brazilian literary criticism, Amado, along with other northeastern writers, is placed in the category of "regionalista" because his text is set in a specific region of Brazil, Bahia. Amado also agrees with them as he says, "Bahia é meu território físico e moral" $(1969$, p.4) but if we look at his themes and topics we cannot ignore that they are not limited only to Brazil or to his Bahia they are universal. Exploring the abandon street children he reminds his readers of Charles Dickens, discussing female questions; prostitution, abortion, rape and adultery he can be placed along with Zola, Flaubert 
or other female writer as a defender of women. Well known modern German writer Anna Seghers does not miss to see these qualities in Amado and justly names him the "Brazilian Balzac." 10

The universality of themes in Amado's writing also can be seen as a result of his proximity with a number of European writers. For a foreign reader his setting was Brazil or more specifically, his Bahia but not his themes. He tries to raise humanitarian questions as he selected these themes. His literary realism helped him not to be lost in the limits of "regional" but to use it as a base, as a platform to denounce social and political absurdities and see them as universal problem:

Não nos pretendíamos modernistas, mas sim modernos: lutávamos por uma literatura brasileira que, sendo brasileira, tivesse um caráter universal; uma literatura inserida no momento histórico em que vivíamos e que se inspirava em nossa realidade, a fim de transformá-la.

(AMADO In RAILLARD, 1992, p. 36)

This universality of focus makes him one of the most read and admired Brazilian writers out of Brazil. ${ }^{11}$ In Tereza Batista, cansada de Guerra Amado depicts the marginalized underworld of prostitution which in no way is limited 
to Brazilian reality. In many ways this novel seems to share the sensibility of not only Emile Zola but also of the American novelist Stephen Crane as it makes one recall Crane's depiction of Bovary slums and Maggie in his novel Maggie: A Girl of Streets. ${ }^{12}$

Though his novels were very well received by both Brazilians foreigners, the critical opinion has been divided from the very beginning. In general, critics interpreted his success in Europe as an outcome of his political affinity but looking at his novels, their themes, characters and their wide spread universe which is made of Brazilian soil, and which is read by people of all sects, and class, by people of both right and leftist ideology we see that such a view has no justification. His affinity with communist party might have hindered his reputation and influenced his reception in Brazil in beginning of his career but today it cannot be judged only by this singular fact. Translation of his works in fifty different languages and also the adaptation by media (both cinema and T.V. serials) of a number of his novels, along with this year long celebration of his centenary in and out of Brazilian territory ${ }^{13}$ proves that it was more than his communist ideology that appealed his readers. In my personal view, in general, people cared little about it and are taken by his writing which is deeply rooted in his sympathy for the marginalized. His defense for the oppressed never seized as his discussion of exploitation of working class presented in his early novels is substituted with the exploitation of people at margin, the 
subaltern; the woman, the prostitute and the street children, in his later writing.

O país do Carnaval, Amado's first novel, was written when he was a young boy of eighteen. Published in 1931, by publisher Schmidt, it was very well received. Amado had published a collection of poetry $A$ luva and a small novel Lenita as coauthor in 1928 he did not include them in the list of his complete works. May be it was the tone of these early works that made him to discard them as they do not fit in his ideology.

From the very beginning Amado's writing attracted foreign readers. His first novel to be translated in a foreign language was Cacau (1933) which was first translated in Spanish by Hector Miri in 1936 and published by Editorial Claridad in Buenos Aires. Then in same year 1936, it was translated in Russian by David Vigodsky and published in Leningrad. This cycle of translations which started with publication of Cacau continues till today. Amado enjoys the longest list of English-language translators, including James L. Taylor, William L. Grossman, Harriet de Onís, Helen Lane, Margaret Neves, Samuel Putnam and Gregory Rabassa. Barbara Shelby translated many of his novels; $A$ Morte e a morte de Quincas Berro D'Agua (1962; The Two Deaths of Quincas Wateryell, 1965) and his later novels Tenda dos Milagres (1969; Tent of Miracles, 1971), Tereza Batista, Cansada de Guerra (1972; Tereza Batista: Home from the Wars, 1975), Tietá do Agreste (1977; Tietá, the Goat Girl, 1979), O sumiço da santa (1988). 
It is also important to note that the translated versions of his works have been published mainly by well known publishers in world; Alfred Knopf in United States, "Progress Publishers" in Soviet Union which was before known as "Foreigner Publishers", Pipper and Volk und Welt in Germany, Gallimard in France, Lousada in Argentina and in Portugal mainly by Lyon de Castro. Apart from this, from very beginning his works called attention of publishers in Iran, Arabian countries, Lebanon, China and Vietnam that resulted in translations of his novels in languages like Persian, Arabic, Lebanese Chinese and Vietnamese. The popularity of his work in this non-European world can be seen through the translation of Seara Vermelha in Hanoi in Vietnamese soon after it was published in Brazil. It appears that it was the suffering of the people in draught ridden land that made it more appealing for the Asian readers.

Unlike any Brazilian writers, many of Amado's novels, with strong Brazilian flavor, were written in foreign lands. In 1988 he said "Infelizmente eu não posso escrever um livro no Brasil. Para trabalhar eu preciso fugir." ${ }^{14}$ Two of his novels, Subterrâneos da Liberdade and O Sumiço da Santa were written in Paris. Tieta do agreste was written in London. His displacement to these European capitals were not merely the result of his persecution by Brazilian dictatorial regime but also were motivated by his need to have privacy and freedom. In his interview to Antônio Roberto Espinosa he explains:

Tieta do Agreste escrevi em Londres, 
no ano de 79, e só foi possível fazer esse livro porque estava disposto a fazer como fiz com Tocaia Grande, passei um ano trancado dentro de uma casa, fugindo de casa em casa; porque estive trancado numa casa nova do João, estive trancado numa casa lá no Maranhão, quando descobriram eu tinha que ir para outra lá em Petrópolis, que passei mais um ano na serra, sem sair [...]. ${ }^{15}$

Amado's popularity, in part can be attributed to the media adaptation. His work has been constantly been adapted for film, television, theater, as well as for comics in Brazil, Portugal, France, Argentina, Sweden, Germany, Poland, the former Czechoslovakia, Italy and USA. Among the directors who have adapted his novels for film and television presentations are Walter George Durst, Alberto D’Aversa, Marcel Camus, Nelson Pereira dos Santos, Carlos Diegues, Bruno Barreto, Aguinaldo Silva and Luiz Fernando Carvalho. Glauber Rocha and João Moreira Salles made documentaries about Jorge Amado.

A number of Amado's novels have been successfully transformed in films or T. V. soap operas. Recently, to celebrate his centenary, T. V. Globo presented a newer version of his very popular novel Gabriela, cravo e canela. On 15 Sep- 
tember 2012, In Salvador, the famous drama society of Bahia "Companhia Baiana de Patifaria" presented the first dramatic version, by dramatist Claudio Simões, of Jorge Amado's novel O sumiço da Santa. Though as a literary critic I see and argue that these media productions have damaged the literary value of his work but I cannot deny that they helped in taking this writer to a much wider public. ${ }^{16}$ Calling our attention to the role of media Amado says:
A adaptação de qualquer obra de um autor é sempre uma violência, mas considero as versões de meus ro- mances para a televisão muito posi- tivas, porque levam a obra a milhões de pessoas que não leriam o livro. ${ }^{17}$

I agree, Amado has reason as people who had no access to his books or who had no ability or time to read his novels could familiarize with his works by these media productions. Apart from this his novels also inspired the musical notes and the plot for Samba. The cinematic transformation of his work projected Amado more as a notorious writer and very few will recall today that as most voted congressman he wrote a bill for religious freedom which was approved in 1945 by Brazilian Congress.

A writer with such wide spread readership, Amado was not worried about the future of his works. In an interview given to Veja (17 September, 1969, p. 6) he said: 
Se minha literatura tiver algum valor artístico e humano, permanecerá. Se não tiver, desaparecerá. Mas, de uma ou outra maneira, terá exercido seu papel no tempo presente. $\mathrm{O}$ fato de que no futuro não existam os problemas de agora não invalida forçosamente a literatura que trata desses problemas nos dias de hoje. O importante é que a literatura atual denuncie a existência dos problemas e contribua para que sejam superados.

Today, after forty four years, with celebrations of his birth centenary in different parts of world, we see the truth behind these concluding words. He is more alive today than ever before. With 20 million of his books sold in 55 countries, Amado today is a literary phenomenon.

Apart from 25 novels, Amado's vast writing carrier comprises of memoirs, biographies, chronicles, poems and children's story. Few of his readers know this face of Amado. For me his long story Gato malhado e a andorinha Sinha (1976) is a beautiful work of children's story also his $\mathrm{O}$ menino grapiuna (1982), a mixture of history and memory, presented in style of autobiography with simplicity and clarity, is his great contribution. The narrative technics used by Amado in these works hold his reader from the first page itself.

Though Amado had lived in a number of coun- 
tries and his works also have been familiar to many of us, few non Brazilians know about Amado's racial identity. During my research I was reading Gregory Rabassa's criticism on Amado and when he referred to Amado as a "Negro writer" I simply accepted it as fact because I also had not seen Amado and had no knowledge about the color of his skin. Moreover, Amado's writing is so sympathetic to the people of color that people who had no opportunity to meet him could easily mistakenly believe that he was black. But when I first met Amado, in Academia de Letras da Bahia, in 1998, during a celebration of "Cinquenta Anos de Capitães de areia", I was taken by surprise. The person in front of me was not black as I had imagined but as white as many of Brazilians are. This is how a writer's identity which differs from his racial, cultural, ethnical or religious identity can be confusing. Similar confusion was created about his birthplace by French publishers. In his interview to journalist Antônio Roberto Espinosa Amado gives details of his birth to clear this confusion, affirming his birth place the small village of Ferradas in a rural area of Bahia:

JA - Eu quero falar um pouco também sobre o meu nascimento porque há uma coisa controvertida. Há notícias diferentes, erradas. Há muitíssimos anos, na Enciclopédia Larousse, da França, existe um verbete que me dá como nascido em Piranji. Piranji é 
uma coisa que não existe mais. Deve existir outro no Brasil, porque aquele teve que mudar de nome, passou a ser Itajuípe. Outro dia, num texto que escrevi para uma revista que dedicou um número a mim, a Vogue, eu disse que não nasci em Piranji, ao contrário, Piranji eu vi nascer. Eu assisti ao seu nascimento, desde as primeiras casas que foram construídas.

Em geral, me dão como nascido em Ilhéus, o que é muito compreensível, pois eu fui pra Ilhéus com um ano, ou, para ser exato, com um ano e cinco meses, pois fui pra lá em janeiro de 14 e nasci em agosto de 12. Mas eu nasci realmente numa fazenda de cacau que meu pai estava montando, perto de um arraial chamado Ferradas, distrito do município de Itabuna. O nome da fazenda era Auricídia... hoje, o arraial cresceu, chegou lá, chegou até a casa onde nasci. Aliás, faz poucos anos, eu estive lá e a população foi muito generosa comigo, muito cordial, todo mundo me esperando na rua...

Sou nascido em Ferradas, distrito 
de Itabuna, sou itabunense, ou seja, sou um grapiúna da região do cacau. Mas Ilhéus também é minha cidade no sentido de que é o lugar onde eu vivi a minha infância - a infância, um tempo muito importante na vida da gente. E também a minha adolescência, as férias. Ilhéus é uma cidade extremamente ligada à minha vida, como todo o sul da Bahia, toda a região do cacau. Itabuna fica a 25 quilômetros de Ilhéus. Quando estava em Ilhéus, ia pra Itabuna sempre. Quando morreu meu irmão Jofre, nós fomos pra Itabuna porque minha mãe não quis ficar em Ilhéus. Passamos lá um ano e tanto, foi quando nasceu meu irmão Joelson, que é médico e mora em São Paulo. Dos três irmãos, o único nascido em Ilhéus é James. Assim, eu sou, ao mesmo tempo, um menino de Itabuna e Ilhéus $[. . .]^{18}$

Amado's simplicity and receptive nature is admired by all of us who had the privilege to meet him in person. Miriam Fraga ${ }^{19}$ (p.77): comes close to my opinion as she says: 
Amado não conhecia limites: além das apresentações, dos prefácios, das indicações para prêmios, com a maior discrição, quase em surdina, ele sempre dava um jeito de abrir as portas, de facilitar as coisas, de aplainar os caminhos. E toda vez com a mesma simplicidade, modestamente, como se estivesse cumprindo uma obrigação.

Raros, muito raros os escritores, artistas ou simplesmente amigos que, de um modo ou de outro, não se fizeram credores de sua generosidade.

I witnessed this generosity of great master who opened doors of his home to a stranger and allowed me not only to have an interview with him but also made me see the simplicity of his nature and the greatness of his heart. To meet and talk to Amado is the biggest achievement of my life in Brazil. Celebrating one hundred years of Amado, I am proud to offer my unpublished interview to the Brazilian readers in my upcoming book on Amado. Initially he had agreed for a 20 minutes interview but the time passed, I was with him for almost 2 hours and 30 minutes.

In his interview given to VEJA magazine (1969, p. 7) Amado says, "Minha casa esta sempre cheia de gente que 
estimo e que também me estima." I know the truth behind these words as I remember my visit to his house. I recall the whole scene today as if I am living it again. As a greedy person I was more interested in our talk then anything else. Hence when we were offered coffee and then later the lunch (it was getting close to twelve and Amado has recently recovered from a heart attack) I politely refused to accept it because I did not want to spend these precious moments of my life drinking or eating. What I wanted was to talk to him and I left his house extremely satisfied but without a drop of water and I could feel that it hurt his Bahian hospitality. He repeatedly said "Ela esta indo seca da nossa casa" he did not know the precious food I had received that day in his house.

I conclude my homage to this great Brazilian writer with following citation from Claude Guméry-Emery (p. 74) who says:

Com Jorge Amado aprendemos a conhecer, respeitar, amar, compartilhar a cultura afro brasileira, a culinária, a capoeira, o candomblé. Aprendemos a conhecer, respeitar, amar o outro, a identidade do outro, a cultura do outro, seja ele quem for.

Muitas pessoas que criticaram o escritor baiano hoje em dia reconhecem que ele abriu caminhos de compreensão, de tolerância, de soli- 
dariedade, pela via literária, tanto no Brasil como no exterior. Jorge Amado sempre exaltou as forças de vida (o eros) contra as forças de morte (o thánatos). Não é um escritor apenas baiano ou brasileiro; é um escritor universal que falou de problemas universais. ${ }^{20}$

After hundred years of his birth we can be certain of one thing that though Amado is truly a Bahian or Brazilian writer but he is limitless, he is universal and "Internationally Loved".

\section{Notas:}

\section{(Endnotes)}

1 In November, 2012 my research Group (GT) "Estudos Comparativos Interculturais" with a support from Associacao Brasileira de Estudos Comparativos - ABRAEC and PPGLI, Departamento de Letras e Artes - Universidade Estadual da Paraiba, celebrated hundred years of Jorge Amado. The event was very aptly titled "JORGE: O INTERNACIONALMENTE AMADO" focusing on Amado's reception in world and bringing forward new ways to look at this great Brazilian writer. During the opening ceremony I had privilege to share MY AMADO with the audience. This article is framed on the lecture I delivered at this occasion.

2 see Caderno de Leituras: A Literatura de Jorge Amado. (Org. Norma 
Seltzer Goldstein) Campanhia da Letras, 1999, p. 74. Also available on cite http://www.jorgeamado.com.br/professores/03.pdf . Hereafter cited as

\section{Caderno de Leituras: A Literatura de Jorge Amado.}

3 I recall specifically Ezra Pound the famous American critic and poet who went through more severe political persecution by American government because of his leftist ideology.

4 For details see SWARNKAR, Sudha, Fallen Woman in Twentieth Century English and Brazilian Novels: A Comparative Analysis of D. H. Lawrence and Jorge Amado. Ph. D. Thesis. University of Warwick, England, 1998.

5 Eduardo de Assis Duarte, "Eles criaram, então, uma certa resistência a uma literatura popular como a dele, que é herança das narrativas do século 19, do romantismo, e que dialoga com o público" em Diogo Guedes, "Jorge Amado segundo a crítica literária" em Jornal do Commercio,04/08/2012.

6 - For details see Diogo Guedes, "Jorge Amado segundo a crítica literária" em Jornal do Commercio, 04/08/2012.

7 For details see http://www.correio24horas.com.br/colunistas/detalhes/ artigo/nelson-cadena-personagens-de-jorge-amado.

8 This branch of Italian Feminist Club is situated in the old palazzo on Via Ragabella in Milan, Italy.

9 Though some words are written differently today, the spelling has been maintained as it was in the 1969 edition of Veja.

10 For details on Amdo's reception in Germany see Armbruster, Claudius., O ciclo do cacau de Jorge Amado, a politica, a literatura e a recepção alemã. wnm.goethe.de > Principal > Eventos > Metamorfoses do Cacau accessed on 5th January 2013.

11 For a long time he was the only Brazilian writer read abroad. Today though Clarice Lispector also enjoys the prestige, Amado loses only in com- 
parison to Paulo Coelho.

12 In his novel Maggie: A Girl of Streets (1900) Stephen Crane depicts the famous Bovary slum of New York city where girls like Maggie were raised and abused.

13 I myself participated in a number of centenary celebrations. Presented papers in September in "100 Anos de Jorge Amado: História, Literatura e Cultura" in Ilhéus and in November in "Coloquio Internacional 100 Anos de Jorge Amado: O escritor, Portugal e o Neoliberalismo" organized by CLEPUL in Lisbon, Portugal.

14 See the link: http://www.quemdisse.com.br

15 The interview was given in July 1981 to journalist Antônio Roberto Espinosa for Caderno de Literatura Comentada, Editora Abril, the article was published with the title "É PRECISO VIVER ARDENTEMENTE". Here after cited as "É PRECISO VIVER ARDENTEMENTE".

16 See SWARNAKAR, Sudha, "The Filmic adaptation of Gabriela" (2011) A paper presented at LASA 2011, Toronto, Canada; SWARNAKAR, Sudha, "Quantas Gabriela(s): Fifty years of Gabriela" a paper presented and published in the $\mathrm{CD}$ of proceedings of "Colóquio Internacional 100 ANOS DE JORGE AMADO: História, Literatura e Cultura", Universidade Estadual de Santa Cruz, Ilhéus, Brazil, September, 2012.

17 Amado's comment, after he watched the media adaptation of the novel in video in Paris, in 1989.

18 See "É PRECISO VIVER ARDENTEMENTE".

19 Caderno de Leituras: a literatura de Jorge Amado, p. 74.

20 Caderno de Leituras: a literatura de Jorge Amado, p. 74. 


\title{
Os milagres da Tenda: uma leitura da mestiçagem em Jorge Amado
}

\author{
Humberto Luiz Lima de Oliveira
}

\section{Introdução}

Quando vemos a reação negativa de setores da população brasileira com as políticas de ação afirmativa, notadamente no que tange às cotas para ingresso na universidade de candidatos de origens afrodescendente ou indígena, como também daqueles oriundos da escola pública cujo contingente populacional é inteiramente constituído de pobres e dentre eles os negros e mestiços majoritariamenteé que podemos compreender o pioneirismo de Jorge Amado ao inserir como herói positivo em suas narrativas literárias o negro Antonio Balduíno, em seu romance Jubiabá (1935). De fato, ao longo da sua carreira de escritor de sucesso, Amado povoaria seus textos literários com personagens negras e mestiças. E, de modo emblemático, em Tenda dos milagres (1969), romance que sintetizaria sua teoria da formação da cultura brasileira que o escritor baiano vê como inteiramente mestiça.

Claro que não desconheço as resistências de setores acadêmicos ao conceito de mestiçagem. De fato, poderse-ia elencar uma série de pesquisadores que preferem utilizar outras designações para se referir aos resultados dos entrecruzamentos. Dentre outras designações, só a título 
de ilustração, podemos encontrar criolização $0^{1}$, diversalite ${ }^{2}$, bibridismo ${ }^{3}$ tanto no Brasil quanto na América Latina, e que vão dando um certo conforto ao fugir do que pareceria um termo problemático ${ }^{4}$. No entanto, quando procuramos saber qual é mesmo o motivo da recusa em aceitar o termo mesticagem encontramos sempre a mesma resposta: "[...] o conceito de mestiçagem foi uma cilada da modernidade, pois sob a aparência da aceitação do múltiplo, se encobriu, na verdade, um projeto racista que previa a mistura das raças, mas com a predominância da raça branca e o branqueamento progressivo da

1 GLISSANT, Edouard, Le Discours antillais, Paris, Seuil, 1981, 504p.

2 BERNABE, Jean, «De l'oralité à la littérature antillaise » in (dir.) TETU LABSADE, Françoise, Littérature et dialogue interculturel, Sainte-Foy, Presses de l' université Laval, 1997.

3 BERND, Zilá, Literatura e identidade nacional, 2.ed. Porto Alegre: UFRGS, 2003,247p.

4 No entanto, assim como ressignificamos tantos outros conceitos e noções que foram durante longo tempo comprometidos, a exemplo de Negro, Mulher, Homossexual, Prostituta, enquanto intelectuais brasileiros, com origem na chamada "impureza", talvez seja tempo de recusarmos qualquer noção hegemônica de identidade. Neste sentido, seria bom que pudéssemos aceitar que o conceito de mestiçagem pode ser lido fora das armadilhas da teoria do branqueamento defendida pelas elites intelectuais e políticas do século passado, ou pelos que preconizam uma certa exagerada "fluidez" ou "liquidez" das questões indenitárias, cf BAUMAN, Zygmunt. Vida líquida. Tradução Carlos Alberto Medeiros. Rio de Janeiro: Zahar, 2007. 
população $[. . .]^{5 "}$ É interessante observar que, embora aceite operar a partir do conceito de híbrido ${ }^{6}$ ofertado por Canclini, esta autora percebe quew também esse termo pode encerrar armadilhas perigosas, constituindo-se em mais uma "[...] utopia da pós-modernidade, a qual estaria encobrindo um certo imperialismo cultural, pronto a apropriar-se de elementos de culturas marginalizadas para reutilizá-los a partir de paradigmas de aceitabilidade das culturas hegemônicas $[. . .]^{7 ’}$.

De fato, o conceito de mestiçagem esteve carregado de negatividade. Não importa qual seja o seu nome, o mestiço vem ao mundo sob o signo da dúvida. Suspeita-se de ser doentio, de não ser capaz de autodeterminar-se e mesmo de não ser capaz de viver em sociedade. Nele estariam estampados os signos da 'impureza' e da "degeneração" da raça. Dele seriam as representações mais doentias que a literatura e o cinema, posteriormente, iriam oferecer.

5 BERND, op. cit. p. 18.

6 É bom não se esquecer que o conceito de híbrido remete diretamente à noção de hybris que, por sua vez, remete a "peso excessivo, força exagerada". A partir do adjetivo híbrido, do latim bybrida, os gregos teriam utilizado esse termo para condenar a misicigenação, vista como "violação das leis naturais". Observe-se também que havia uma forte crença de que o híbrido, o miscigenado seria tomado por forças incontroláveis (a fúria ou o orgulho, por exemplo). Neste caso, o indivíduo estaria sujeito à incapacidade de autogerir-se e autocontrolar-se, sendo instado por sentimentos violentos que as paixãos exageradas(doenças) iriam impulsionar sobre seu ser que estaria em permanente estado de desequilíbrio e irracionalidade.

7 BERND, ibid. 
Importa saber que, ao indivíduo que seria portador de marcas de uma dupla identidade, o modelo binário de pensamento ( $=$ ou isto, ou aquilo) consideraria demasiado fora dos padrões, excêntrico, logo, inaceitável, um 'terceiro excluído', não sendo nem A, nem B. Assim, o mestiço seria apreendido como, "o que não encontra lugar entre os demais", pois que seria "um sem par", "um sem igual”, isto é, não seria idêntico a nenhum dos grupos que o circundam e o comprimem e aos quais poderia alegar uma relação de pertença ${ }^{8}$.

No entanto, gostaria de colocar essa questão em outros

8 Em caráter exemplar, o cinema estadunidense foi pródigo em representar o mestiço de branco e índigena que não conseguia definir o seu espaço,sob o nome de Renegado. Na verdade, este indivíduo não conseguiria jamais definir seu grupo de pertença, e pior ainda, em caso de desejar optar pelo grupo dominante ou no caso branco-europeu, seria rejeitado, pois carregaria consigo as marcas muito evidentes de sua própria estranheza. Basta lembrar, por exemplo, o filme de John Ford, Rastros de ódio ( The Searches), de 1956; ou ainda Pequeno Grande Homem (Little Big Man) EUA - 1970 (dir.) Arthur Penn, com Dustin Hoffman no papel do mestiço Jack Crabb. Na literatura brasileira, O Mulato (1881) um clássico do Naturalismo, de autoria de Aluísio de Azevedo traz o drama de Raimundo que, desconhecendo sua cor, "branqueado" pela ascensão social, ao mudar de domicílio, defronta-se com preconceitos que não consegue entender. No que tange à figura da mulata, tanto a literatura quanto a música popular brasileira seriam pródigas em defini-la com as marcas do exagero, logo da desmedida, e por isso com forte apelo sexual. Cf. QUEIROZ FILHO, Teófilo de. Preconceito de Cor e a Mulata na Literatura Brasileira. São Paulo: Ática,1975. 
termos, ou seja, se não seria possível pensar o mestiço como sendo aquele que pode transitar - sem esconder por vezes seu desconforto, fruto das tensões das negociações nem sempre amigáveis, mas sempre possíveis - logo o que passeia, se move por e entre culturas diferentes, das quais, como verdadeiro canibal devora o que necessita para saciar sua fome de ser e de viver, de saber e fazer, de se fazer presente no mundo? É assim que compreendo e trago à discussão o conceito de mestiçagem. Sem nenhum medo de Ser, sem nenhum receio de parecer "exagerado". Ou de viver a incompletude do ser que é bem humana, como nos mostram a Filosofia do Ocidente e a sabedoria dos povos ditos arcaicos ou primitivos.

Assim pensando, proponho-me, neste trabalho, a fazer uma releitura do romance Tenda dos milagres, de Jorge Amado, para tentar responder a esta hipótese que me faz acreditar que o mestiço é aquele que pode estabelecer diálogo, logo conviver, de maneira plural, pois que carregaria em si mesmo toda uma memória genética que o leva a identificar-se com duas ou mais culturas, etnias, ou mesmo raças, se quisermos insistir nesta noção que é geradora de toda uma série de estereótipos ainda recorrentes no imaginário social da sociedade brasileira e até mesmo ocidental, sobretudo daquelas que conheceram a escravidão.

\section{Os milagres da tenda amadiana}

Somente quando nos lembramos do horror das teorias raciais é que podemos reconhecer a grandeza, a relevância e a pertinência para nós brasileiros e baianos, negros e 
mestiços, da obra amadiana e em especial de Tenda dos milagres e da personagem mais instigante, mais humana e mais comovente da literatura baiana. Pois Pedro Archanjo é desenhando, moldado e construído para se contrapor às teorias raciais, em especial, ao seu maior ideólogo por seu caráter de disseminador: Arthur de Gobineau que foi Embaixador francês na Corte imperial brasileira e que se admirava de como eram feios os brasileiros!?

Transplantada das ciências naturais, a noção de raça seria utilizada para explicar o desenvolvimento das civilizações, da evolução humana através dos tempos, e, a partir de apropriações dos conceitos de mestiçagem e degeneração das espécies, intelectuais europeus passariam a temer que o entrecruzamento de raças e culturas, por seu caráter de 'impureza' gerasse indivíduos doentios ou fracos, cuja debilidade de caráter fosse incompatível com a noção de darwinismo social então em voga. De fato, sobre o Negro, Gobineau, o principal difusor das teorias raciais diria que,

9 Morando no Rio de Janeiro, Embaixador francês na Corte imperial de Pedro II, Gobineau diria que os brasileiros eram incontestavelmente um povo feio, logo um resultado ruim da mestiçagem das raças. Aliás, para Gobineau e demais teóricos da pureza racial, toda e qualquer mistura ou mestiçagem teria como resultado a degeneração. Logo, o mestiço, o brasileiro típico era um degenerado, doentio, incapaz de progresso. Talvez por isso, durante muito tempo, décadas, talvez séculos, tenha-se pensado na impossibilidade de o Brasil vir a ser um grande país: pelo caráter mestiço do seu povo. 
[...] La variété mélanienne [à pigment de peau foncé] est la plus humble et gît au bas de échelle. Le caractère d' animalité empreint dans la forme de son bassin lui impose sa destinée, dès l'instant de sa conception. Elle ne sortira jamais du cercle intellectuel le plus restreint [...] Si ces facultés pensantes sont médiocres ou même nulles,[le Noir] possède dans le désir, et par suíte dans la volonté, une vigueur souvent terrible. Plusieurs de ses sens sont développés avec une vigueur inconnue aux deux autres races: le goût et l'odorat, principalement ${ }^{10}$.

Quanto à mestiçagem, objeto de nosso trabalho, Gobineau diria que, se num primeiro momento seus resultados não são nocivos, pois afinal, um elemento considerado "superior" é acrescido a outros considerados "inferiores", e assim fortaleceria o que 'naturalmente' seria 'fraco', no entanto, isto contribuiria, a médio e longo prazo para que o elemento dito 'superior', no caso a raça e a cultura branco-europeias, fossem pouco a pouco perdendo suas 'melhores

10 GOBINEAU, Arthur de, GOBINEAU, Joseph-Arthur, L'inégalité des races humaines, in http://www. http://www.philo5.com/Les\%20philosophes\%20Textes/Gobineau_InegaliteDesRacesHumaines.htm 
características':

[...] Le monde des arts et de la noble littérature résultant des mélanges du sang, les races inférieures améliorées, ennoblies, sont autant de merveilles auxquelles il faut applaudir. Les petits ont été élevés. Malheureusement les grands du même coup, ont été abaissés, et c' est un mal que rien ne compense ni ne répare.[...] La race blanche possédait originairement le monopole de la beauté, de l'intelligence et de la force.

(Ibid, os grifos são meus)

O certo é que, catalogadas de acordo com padrões eurocêntricos e numa escala que considerava a civilização branco-europeia como superior e, em graus tanto mais inferiores quanto mais se distanciassem do modelo dominante, as demais raças eram hierarquizadas, tendo no topo a raça branca e na base, num estágio de total despossessão das coisas do espírito, os povos sem escrita e sem Estado, apreendidos como alteridade radical, exotismo, diferença a ser eliminada por sua absoluta estranheza. Sociedade marcada pela herança escravagista e pelo passado colonial, o Brasil despontava no século XX como uma nação condenada ao atraso econômico por sua população, avaliada como "débil ou doentia" por seu 
caráter miscigenado (BASBAUM, 1976, p.65-78). Ficava assim legitimadas tanto a escravidão dos povos africanos quanto a própria colonização européia sobre vastas regiões do planeta. As teorias raciais constituíam-se numa contundente:

[...] investida contra os pressupostos igualitários das revoluções burguesas, cujo novo suporte intelectual concentrava-se na ideia de raça que, em tal contexto, aproximava-se cada vez mais da noção de povo. O discurso racial surgia, dessa maneira, como variante do debate sobre a cidadania, já que no interior desses novos modelos discorria-se mais sobre as determinações do grupo biológico do que sobre o arbítrio do indivíduo entendido como "um resultado, uma retificação dos atributos específicos da raça."

(SCHWARCZ, 1995, p.46-47)

É sob a sombra da suspeita de ser uma sociedade doentia que o Brasil desponta no século XX, com feridas ainda muito recentes de um passado escravocrata, com abismos sociais entre as classes e raças, onde predominavam tanto uma tentativa simiesca de copiar o estilo de vida da Europa, notadamente da França, quanto uma recusa da 
maioria da sua elite intelectual em aceitar a rica contribuição da herança cultural africana. Preconceito e racismo grassam na vida social de um país com vergonha de ser mestiço e desejoso de esconder as marcas étnicas que o faziam 'impuro', isto é, mestiço.

Protagonista de Tenda dos Milagres (1969), 'romance de tese', escrito por Jorge Amado, Pedro Archanjo pode ser visto como um lídimo representante de um povo que, não tendo trabalho organizado, vivendo na penúria e na pobreza, consegue manter sua liberdade individual intacta na medida em que permanece livre dos grilhões que a moral burguesa estabelece como normas de conduta. De fato, fora do sistema de produção capitalista, desassistido pelo Estado, um povo inteiro, milhares de homens, mulheres e crianças, descendentes diretos dos antigos escravos africanos, vivem, no Pelourinho e adjacências, o que o narrador chama de "mistério primitivo", tendo como contraponto a imponente Faculdade de Medicina da Bahia, "templo da ciência', onde predominam as teorias raciais, considerando o negro e o indígena como raças inferiores, e o mestiço dos entrecruzamentos sendo visto como degenerescência, ou doença. Na verdade, são esses homens e mulheres que, por não terem preço algum a pagar, pois nada recebem do Estado - o qual, aliás, não lhes assiste, pois não lhes reconhece a cidadania - por isso mesmo podem vivenciar o que Albert Camus considerava uma "barbárie outorgada e 
fecunda ${ }^{11}$ " e que confirma a existência de uma outra forma de viver, pensar, sonhar e sentir que o avanço do capitalismo - com a racionalização do trabalho e a domesticação dos instintos - poderia neutralizar, esmaecer ou anular.

Pedro Archanjo constitui-se no mestiço a quem a narrativa investe de positividade, ao torná-lo detentor das qualidades da racionalidade que os intelectuais da tradição evolucionista negavam, e que tornava pessimista a perspectiva de desenvolvimento real do capitalismo na nação brasileira por ser mestiça. Com a construção desta personagem, Jorge Amado mostra a chamada reversão dessa expectativa. Ou seja, este herói mulato deverá reconstituir no texto narrativo (= retrato da nação) a formação da identidade nacional, inserindo a contribuição da herança africana, em oposição à visão das classes dominantes representadas no romance pela figura de Nilo Argolo, o qual, em 1901, num congresso no Rio de Janeiro, publica $A$ degenerescência psíquica e mental dos povos mesticos - o exemplo da Babia, defendendo a tese de que o atraso socioeconômico da sociedade brasileira estaria diretamente vinculado à presença do elemento africano e sua "mistura" com o sangue branco-europeu, gerando uma "raça inferior".

11 Camus apresenta Babia de tous les saints (Jubiabá), na França de modo altamente elogioso e contrapondo a literatura produzida por Amado à cerebral, segundo ele, e fria literatura francesa da época. Cf. , Babia de Tous les Saints article d'Albert Camus (Alger Républicain, 9 avril 1939) http:// authologies.free.fr/amado.htm. 
Na verdade, o autodidata Pedro Archanjo é uma releitura que Amado faz da antropofagia. Falando corretamente línguas estrangeiras, com especial notoriedade para o seu "francês de Paris", além do espanhol, do inglês e do italiano, na biblioteca de Pedro Archanjo há um considerável acervo da cultura ocidental: de Franz Boas e a nova interpretação sobre as culturas, a Alexandre Dumas e Gobineau, dos mitos gregos ao cordel. É esta sua bagagem cultural tão vasta, aliada ao agudo senso de realidade que o faz ser capaz de articular relações, que o leva a escrever seus quatro livros ( $A$ vida popular na Babia - (1907); Influências africanas nos costumes da Babia -(1918); Apontamentos sobre a mesticagem nas Famílias baianas (1920) e A Culinária baiana: origens e preceitos (1930), os quais, cem anos depois, vão despertar o interesse de um catedrático estrangeiro e que vem à Bahia, exclusivamente, para constatar as afirmações de Pedro Archanjo sobre a miscigenação das raças e das culturas, como fator positivo, para comprovar que “[...] É mestiça a face do povo brasileiro e é mestiça a sua cultura"(TM, p.98).

Por isso, de modo metódico, sistemático, a personagem de Pedro Archanjo será capaz de competir no meio intelectual, mesmo se (ou principalmente se) contando com a ajuda divina, de Xangô, e da figura da branca-pobre Zabela, a “condessa de Água Brusca”, socialmente rejeitada por recusar os padrões da moral burguesa.

Dois mundos, duas cosmogonias: o mistério primitivo e a ruptura da ordem estabelecida pela racionalidade oci- 
dental vão confluir para possibilitar que Archanjo se aproprie das ferramentas necessárias para a transposição dos umbrais. E, para realizar a missão que lhe fora confiada pelos deuses afro-brasileiros, Archanjo deverá enquadrar-se na necessária disciplina, devendo abandonar a vida boêmia e malandra em que até então vivera.

Portanto, se a narrativa aponta para o papel de mediador reservado a Pedro Archanjo, outro espaço ser-lhe-á conferido. E, para que possa desempenhar a mediação necessária entre os mundos, ele contará com forças sobre-humanas, que o farão ultrapassar as limitações do plano social e econômico. E quem vai orientá-lo, direcioná-lo para a tarefa que lhe esperava é Majé Bassan, a analfabeta, a que vive na oralidade, no 'mistério primitivo".

É que, numa clara ironia, Jorge Amado brinca com os preconceitos e faz com que a voz que chamará Archanjo à ordem, que o disciplinará, que o incitará a cumprir sua obrigação, seja a voz da guardiã, da detentora do patrimônio religioso, cultural e linguístico da tradição africana, a grande sacerdotisa Majé Bassan.

De fato, é esta Mãe-de-Santo quem insistirá para que Archanjo passe da oralidade à escritura, preparando-se para enfrentar o perigo das idéias racistas, e abra caminho para um futuro que não seria tão remoto assim, e que deveria ser vivido por sua comunidade (p.97). Eis o que ela diz:

Soube que tu disse que vai escrever um livro, mas sei que tu não está fa- 
zendo, o teu fazer é da boca pra fora, tu se contenta com pensar. Tu passa a vida xeretando de um lado para outro, conversa aqui, conversa ali toma nota de um tudo e prá quê? Tu vai ser toda a vida contínuo de doutor? Só isso e mais nada? O emprego é pra teu de comer, para não passar necessidade. Mas não é para te bastar nem para te calar. Não é para isso que tu é Ojuobá.

(TM: 97)

Para tornar possível sua missão, os deuses concedem dons especiais a Pedro Archanjo:

Uma versão circula entre o povo dos terreiros, corre nas ruas da cidade: teria sido o próprio orixá (Xangô) quem ordena a Pedro Archanjo tudo ver, tudo saber, tudo escrever. Para isso fizera-o Ojuobá, os olhos de Xangô. [.....] Moço de vinte e poucos anos[....]Pedro Archanjo deu na mania de anotar histórias, acontecidos, casos, nomes, datas, detalhes insignificantes, tudo quanto se referisse à vida popular. Para quê? Quem sabe lá. Pedro Archanjo era cheio de qui- 
zilas, de saberes e certamente não se devera ao acaso sua escolha, tão moderno ainda, para alto posto na casa de Xangô: levantado e consagrado Ojuobá, preferido entre tantos e tantos candidatos, velhos de respeito e sapiência. Coube-lhe, no entanto, o título, com os direitos e deveres; não completara ainda trinta anos quando o santo o escolheu e o declarou: não pudera haver maior acerto- Xangô sabe os porquês.

(sic) (TM: 70)

Maior entre os anjos, por isso, Archanjo, Pedro será assim visto por dois mundos diferentes com seus respectivos imaginários: de um lado, será apenas um 'pobre, pardo e paisano'; de outro, um iluminado, um herói com halos de luz divina que tem por missão derrubar preconceitos e dar visibilidade social à cultura do povo negro-mestiço, resgatando orgulho e dignidade. Portanto, a incumbência de Pedro Archanjo é inserir na moldura do retrato da nação outras figuras que, na visão amadiana, compondo a brasilidade, ficaram excluídas do retrato indenitário nacional que as elites tentavam forjar.

Observe-se que, praticamente, ignorado em sua própria terra, depois de "descoberto" pelo "sábio americano", 
Pedro Archanjo passará a ter seu nome veiculado pela mídia, recebendo elogios de quem até mesmo o menosprezava. Jorge Amado aproveita para brincar com o pensamento subalterno que caracteriza grande parte da intelectualidade dos chamados países do 'terceiro mundo' ou colonizados, onde os intelectuais, assim como os professores universitários, tornam-se orgulhosos comentadores, repetidores.

Exemplo dos mais significativos do trânsito de Pedro Archanjo entre os mundos é o episódio do Terreiro d’Ilé Ogunjá. De fato, agonizante, antes de morrer, Majé Bassan, a grande sacerdotisa "[...] Mistura as línguas, usa palavras e frases iorubás, [...]” para transmitir a Pedro Archanjo "[...] a última lição, o ensinamento derradeiro [...]” (p.167) que o consagrará como babalorixá. Desta forma, doravante será ele o grande sacerdote responsável pela tradição, o indivíduo capaz de conjurar os deuses, de fazer acontecer o axé, logo de fazer o enunciado concretizar-se, plasmar-se no plano do real.

Assim, quando o comissário Pedrito Gordo chega com a milícia para impedir as celebrações e destruir o terreiro, Pedro Archanjo perceberá que um resto de respeito e temor ainda brilhava no olhar do bandido mais perigoso, Zé Alma Grande, ao entrar no espaço sagrado do terreiro, em plena noite de festa dos Orixás.

Adiantou-se o negro maior do que um sobrado.Ojuobá percebeu com os olhos de Xangô um átimo de vacilação no passo do facínora ao pe- 
netrar no recinto sagrado do Terreiro. Samuel Cobra Coral e Zacarias da Goméia tomaram posição, prontos para impedir qualquer protesto. Procópio prosseguiu na dança, era Oxossi,o caçador, senhor da selva, rei de Ketu.

Contam que, nessa hora exata, Exu, de volta do horizonte penetrou na sala. Ojuobá disse :Larioê, Exu !Foi tudo muito rápido. Quando Zé Alma Grande deu mais um passo em direção a Oxossi, encontrou pela frente a Pedro Archanjo. Pedro Archanjo, Ojuobá ou o próprio Exu conforme opinião de muitos. A voz se abriu imperativa no anátema terrível, na objurgatória falta!

-Ogun kapê Dan meji, Dan pe lú oniban!

Do tamanho de um sobrado, os olhos de assassino, o braço de guindaste, as mãos de morte, estarrecido, o negro Zé Alma Grande parou ao ouvir o sortilégio. Zé de Ogun deu um salto e um berro, atirou longe os sapatos, rodopiou na sala, virou 
orixá, no santo sua força duplicava. Ogunhê! gritou, e todos os presentes responderam: Ogunhê, meu pai Ogun!

-Ogunkapêdanmeji, danpelúoniban !

- repetiu Pedro Archanjo:- Ogun chamou as duas cobras e elas se ergueram para os soldados!

Ergueram-se os braços do orixá, as mãos de tenazes eram duas cobras: Zé Alma Grande, Ogun em fúria, partiu para Pedrito [...]. (p.195-196).

Pedro Archanjo sabe que o mito, mesmo se adormecido no coração do homem, mesmo se esquecido na alma, é capaz de despertar ante sua evocação. Desta forma, o antigo Zé de Ogun, que abandonara os terreiros para tornar-se criminoso, que repudiava as tradições do povo de santo, em plena batalha, vindo para destruir, ele termina por ser convocado ao serviço das divindades, voltando a assumir sua antiga identidade, e assim evita a destruição do terreiro e põe em fuga o comissário arbitrário, que será demitido da polícia, diante dos novos tempos que surgem no cenário social da Bahia que Jorge Amado descreve.

Por isso, pode-se afirmar que Pedro Archanjo é uma das mais instigantes e singulares personagens amadianas, talvez por se constituir, de fato, numa espécie de alter ego do 
próprio escritor, numa projeção das idealizações do papel do escritor, enquanto intelectual, e do próprio homem. Na verdade, Pedro Archanjo é uma figura aparentemente paradoxal: irresistível sedutor, conquistador de mulheres, exatamente para provar o senso moral dos "negros, pardos e mestiços"dos quais as teorias raciais alegavam a degenerescência,- no entanto, colocará a honra acima do amor e se negará a trair seu amigo-irmão Lídio Corró, deixando de amar a mulher dos seus sonhos, o seu verdadeiro amor, a "mais bela das belas, Rosa de Oxalá".

É que Pedro Archanjo, o invejável macho criado por Amado, é, na verdade, um homem sensível, que não apenas gosta, mas também ama a mulher, diferente do mito do Don Juan e seu fastio pela vida e desprezo pela mulher. Longe do conquistador compulsivo que se compraz no ato da conquista, na posse da "presa", Pedro Archanjo é cobiçado, desejado, pelo seu jeito especial de ser, distanciando-se da figura tradicional do "macho predador". As mulheres o amam em completa liberdade. Poder-se-ia dizer que o desejo feminino vai ao encontro do desejo do homem que é Pedro Archanjo. Por ele suspiram mocinhas e mulheres maduras, inexperientes donzelas e feridas mulheres da vida para quem ele, com delicadeza e firmeza, irá oferecer-lhes, não importa a idade, ou o momento, o prazer de amar regado com delicadeza e erotismo, aliviando os sofrimentos do corpo e da alma.

[...] Pedro Archanjo, um retado na cama, e quanta delicadeza! [...] (p.30) 
[...] Ela adormecera a sorrir, no calor das doces palavras de ternura, tão boas de ouvir e tão desejadas. [...] Rosália praticou em Alagoinhas, [...] e Pedro Archanjo a encontrou no Terreiro de Jesus comprando laranjas. Só então Rosália soube com certeza que era um ser humano e não uma coisa, um trapo, uma puta tãosomente [...]. (p.153).

Lutando em favor do seu povo, como um guerreiro, e ao mesmo tempo como um intelectual 'orgânico', Pedro Archanjo profetizará as transformações sociais que a sociedade brasileira conhecerá, numa clara demonstração do poder visionário de seu criador, Jorge Amado, ao fazer seu herói narrativo afirmar que:

[...] Eu penso que os orixás são um bem do povo. A luta da capoeira, o sambade-roda, os afoxés, os atabaques, os berimbaus, são bens do povo. [...] Sou a mistura de raças e homens, sou um mulato, um brasileiro. [...] Amanhã [...] tudo já terá se misturado por completo e o que hoje é mistério e luta de gente pobre, roda de negros e mestiços, música proibida, dança ilegal, candomblé, 
samba, capoeira, tudo isso será festa do povo brasileiro, música, balé, nossa cor, nosso riso, compreende? (p.201).

\section{Considerações Finais}

A releitura de Tenda dos milagres torna-se mais eficaz quando podemos constatar que a ideia de um progressivo branqueamento da população brasileira, tão cara aos adeptos e difusores das antigas teorias raciais, ainda impregnada nas mentes e corações de gerações inteiras, esta ideia é cada vez mais desmentida pela realidade. De fato, basta ver a cidade de Salvador, capital do Estado da Bahia, ou as cidades do Recôncavo baiano, para constatar que, de maneira irreversível, a sociedade baiana é, em sua maioria, negro-mestiça ${ }^{12}$.

De fato, o que se pode ver na Bahia, sobretudo na zona litorânea, historicamente povoada pelos antigos escravos negros, é a consolidação de uma mestiçagem de raças e culturas, com uma surpreendente riqueza dos patrimônios africanos, europeus e ameríndios, mesmo se, de modo explícito, a depender do espaço social, da situação, e do interlocutor, a coexistência democrática, a inclusão social deva ainda constituir-se em objeto de negociação que pode ir da simples concorrência à luta, por vezes acirrada, pelo reconhecimento dos direitos, logo, indo do diálogo à confrontação.

12 Os dados compilados pelo IBGE indicam que mais de 85\% da população de Salvador se diz negra ou parda, logo mestiça. 
Esse povo negro e mestiço, mergulhado na maior pobreza, sem a assistência dos poderes públicos de modo brutal até o início dos anos noventa do século XX e, que, de modo lento, começa a ser integrado graças às políticas de ação afirmativa a partir de 2003, é um enorme contingente populacional que jamais teve acesso ao emprego regular, sendo-lhe reservado apenas as atividades braçais dada sua baixa escolaridade.

Enfim, a própria indústria cultural, tal como prevista por Amado em Tenda dos Milagres, aciona, promove, difunde, veicula e alimenta toda uma ideia de mestiçagem cultural e enfatiza o caráter mestiço do povo baiano. O Pelourinho, cenário magnífico onde se desenrola Tenda dos Milagres, serve como principal atração turística da Bahia e é, no plano real, majoritariamente povoado por uma população negra e mestiça.

Por isso, pode-se dizer que, de modo inaugural, Amado antevê o que viria a ser uma consolidação da mestiçagem da sociedade baiana e brasileira, por extensão. E, para ilustrar a riqueza de um patrimônio cultural e humano que o escritor entende ser uma contribuição valiosa para a humanidade, apontando para a possibilidade de uma convivência pacífica entre os povos de diferentes etnias ou raças, é que Amado esboça a figura de Pedro Archanjo-Ojuobá, visto por dois mundos diferentes, pertencendo a mundos considerados em oposição, transitando entre culturas e construindo uma nova cultura que não exclui as demais, mas as ultrapassa, seleciona o que cada uma tem de melhor, elimina intransigências e assim supera dicotomias, afasta os perigos de um essencialismo identitário. 
Longe das armadilhas das identidades fixas, Amado nos mostra que a diversidade não exclui a unicidade, que sob a aparente diferença encontra-se a mesma humanidade que é sentida, percebida e vivida além de toda fronteira de raça, classe, cor, religião, língua... em sua permanente multiplicidade do Um. Assim é que posso ler esta personagem carregada de generosidade e amorosidade, uma personagem que nos sinaliza para um modo de ser onde prevalece o cuidado. Por isso, posso considerar que esta personagem está no que se convenciona chamar de entre-lugar, ou entre dois, em sua celebração do Diverso.

Enfim, onde tudo era dividido, só Pedro Archanjo filho de um pai que não o conheceu e de uma mãe que o deixaria órfão ainda criança - esta personagem que se entregava nos terreiros às divindades, que lia tratados, que debatia com os intelectuais da tradição branco-europeia, que nascendo em 1868 já não mais conheceria a escravidão, vivendo num tempo onde tudo parecia excludente, bipolar, só Pedro Archanjo-Ojuobá foi inteiro :

Não se dividiu em dois, com hora marcada para um e para outro, o sábio e o homem. Recusou subir a pequena escada do sucesso e alcançar um degrau acima do chão onde nasceu, chão das ladeiras, das tendas, das oficinas, dos terreiros, do povo. Não quis subir, quis andar para a frente e andou. Foi mestre Archanjo Ojuobá, um só e inteiro .(sic) (p.141). 
Como só pode ser um homem com a consciência de si e do mundo, que traz em si mesmo o Sim e o Não, que transita entre mundos e está no entre-lugar, espaço dos que reelaboram as tradições e as atualizam em contínuas traduções.

\section{Referências}

AMADO, Jorge. Tenda dos milagres. São Paulo: Martins Fontes, 1969

AMADO, Jorge. La boutique aux miracles. Traduzido por Alice Raillard. Paris: Stock, 1976.

BASBAUM, Leôncio. História sincera da República: das origens a 1889. 4. ed. São Paulo: Alfa-Ômega, 1976.

BAUMAN, Zygmunt. Vida líquida. Tradução Carlos Alberto Medeiros. Rio de Janeiro: Zahar, 2007.

BERNABE, Jean, «De l'oralité à la littérature antillaise » in (dir.) TETU LABSADE, Françoise. Littérature et dialogue interculturel. Sainte-Foy : Presses de l' Université Laval, 1997. BERND, Zilá. Literatura e identidade nacional. 2.ed. Porto Alegre: UFRGS, 2003.

CAMUS, Albert. Bahia de Tous les Saints article d'Albert Camus (Alger Républicain, 9 avril 1939) http://authologies. free.fr/amado.htm . 
FANON, Frantz. Pele negra, máscaras brancas. Rio de Janeiro: Fator, 1983.

FANON, Frantz. «Racisme et culture», Présence Africaine, Comte Rendu du $1^{\text {er }}$ Congrès International des écrivains et artistes noirs. Paris: Sorbonne, octobre, 1956.

FANON, Frantz. Os condenados da Terra. Rio de Janeiro: Civilização Brasileira, 1979.

FREYRE, Gilberto. Casa Grande \& Senzala. 25. ed, Rio de Janeiro: 1987.

GLISSANT, Edouard. Le Discours antillais. Paris: Seuil, 1981.

GOBINEAU, Arthur de, GOBINEAU, Joseph-Arthur. L'inégalité des races humaines, in http://www.philo5. com/Les\%20philosophes\%20Textes/Gobineau_InegaliteDesRacesHumaines.htm

LÉVI-STRAUSS, Claude, Race et Histoire, Race et culture. Paris : Albin Michel, UNESCO, 2001.

LIMA DE OLIVEIRA, Humberto Luiz. La perception de l' “Autre" à travers Ashini (1960) d' Yves Thériaul au Canada, Tenda dos milagres (La Boutique aux miracles, 1969), de Jorge Amado au Brésil et L' espérance macadam (1995), 
de Gisèle Pineau, aux Antilles.Thèse de doctorat. Sous la direction d' Alain Vuillemin. Université d' Artois, France, 2009.

LOPES, Helena Teodoro; SIQUEIRA, José Jorge; NASCIMENTO, Maria Beatriz. Negro e cultura no Brasil. Rio de Janeiro: Ibrade-Unesco, 1987.

NINA RODRIGUES, Raimundo. Os africanos no Brasil. 7.ed. Brasília: UNB, 1988.

ORTIZ, Renato. Cultura brasileira e identidade nacional. 4. ed. São Paulo: Brasiliense, 1994.

QUEIROZ FILHO, Teófilo de. Preconceito de cor e a mulata na literatura brasileira. São Paulo: Ática, 1975 RAILLARD, Alice. Conversando com Jorge Amado. Rio de Janeiro: Record, 1999.

SANSONE, Lívio. A internacionalização da cultura negra. Novos Estudos CEBRAP, n. 56, p.111- 136, mar. 2000, São Paulo.

SCHWARCZ, Lília Moritz, O espetáculo das raças: cientistas, instituições e questão racial no Brasil. 1870-1930. São Paulo : Companhia das Letras, 1995. 


\title{
Do Modernismo Paulista ao Regionalismo do Nordeste
}

\author{
Cid Seixas FragaFilho
}

A partir de 1928, com a guinada telúrica dos modernistas de 22, o Nordeste, até então refratário às novidades europeizantes da Semana de Arte Moderna, encontra uma possível identidade entre as suas embrionárias vertentes de modernidade literária e as propostas "futuristas" e modernistas capitaneadas pela nova metrópole econômica do país.

Seguindo, inconscientemente, o exemplo pioneiro de Gilberto Freyre, em Pernambuco, Jorge Amado e outros jovens intelectuais da província inserem a Bahia no quadro do pensamento artístico e social do Século XX. Posturas contrárias aos gritos histriônicos da paulicéia desvairada eram vistas como forma de atraso cultural do Nordeste, enquanto os escritores dessa região brasileira perseveravam na gestação de uma nova consciência crítica que explodiria dois anos depois, com o chamado Romance de 30.

Enquanto a arte concebida pelos jovens do centro metropolitano construía sua identidade a partir do alimento antropofágico digerido na Europa, os jovens da "roça" tiravam da terra as raízes com que se alimentavam. Mesmo em São Paulo, um intelectual como Monteiro Lobato adotou, pioneiramente, postura similar a que viria a caracterizar a literatura nordestina, sendo de pronto execrado pela vaia juvenil 
e visto como um passadista. Tais fatos - que daqui a dez anos serão anciões centenários (quando a Semana de 22 completará um século) - exigem um reexame com olhos do hoje.

Em fevereiro de 2022 o Brasil estará celebrando a aventurosa eclosão da Semana de Arte Moderna, nome pomposo para os três dias de eventos realizados no Teatro Municipal de São Paulo. Artes plásticas, literatura e música foram os temas centrais das discussões e performances distribuídas na segunda-feira, dia 13, na quarta, dia 15, e na sexta-feira, dia 17 de fevereiro de 1922. Espera-se que, no bojo do centenário, sejam vistos e compreendidos os fatos que, ao longo do século XX, ganharam um estatuto mítico capaz de enublar tudo aquilo que não representasse uma aceitação passiva e contritamente religiosa dos feitos e fatos traquinados pelos seus corifeus.

O espírito de corpo dos chamados modernistas conduzia um rolo compressor capaz de esmagar, como uma camada de lama, a todos aqueles que não demonstrassem uma aceitação incondicional ao pensamento "novo". Todos conhecem o estigma imposto pelos "vanguardistas" ao "passadista" Monteiro Lobato. Como o furacão da botocúndia derrubou os cavaletes da exposição de Anita Malfatti, conjeturada por Lobato como paranóia ou mistificação, os pontasde-lança do modernismo conseguiram, por algum tempo e em vários contextos, esvanecer o esplendente vendaval com que Lobato enriqueceu a cultura brasileira, desenterrando os tesouros escondidos no mato e nas ruas obscuras. As idéias 
do Jeca Tatu, ironicamente esboçadas por Monteiro Lobato como proposta de construção da identidade nacional, não foram percebidas num momento em que o Brasil buscava uma fisionomia européia.

É verdade que a partir de 1928 o modernismo brasileiro passou a merecer este adjetivo brasileiro, mas o fosso estava cavado e dividia profundamente os territórios da arte. Convém lembrar que Oswald de Andrade, passados os embates da chamada fase destrutiva do modernismo, mostrou o significativo fato de Urupês ser anterior a Pau Brasil e à obra de Gilberto Freyre. Reconhecia, assim, o valor e a consistência do pensamento de Monteiro Lobato, aproximando a guinada de 28 do pioneirismo do velho amotinado de Taubaté, com a seguinte confissão: "nós também trazíamos nas nossas canções, por debaixo do futurismo, a dolência e a revolta da terra brasileira.” (ANDRADE, 1971, p.4).

O episódio constituído pela crítica de Lobato à pintora Anita Malfatti, publicada em dezembro de 1917, oito dias após a abertura da exposição, demorou para ser superado, especialmente pela declarada opção do autor pela arte clássica e pela crença na sua permanente e irretocável perfeição. Contraditoriamente ao que ele realizou como escritor e como intelectual sensível à cultura brasileira, no famigerado artigo cometeu um equívoco "passadista" ao pontificar: "Todas as artes são regidas por princípios imutáveis, leis fundamentais que não dependem da latitude nem do clima." (LOBATO, 1917/1967, p.60). 
Ao tempo em que argüia ferozmente a adesão de Anita às vanguardas européias, o escritor exaltava seu talento e suas qualidades. No pensamento crítico de Monteiro Lobato estava fortemente embutida a proposta de construção de uma estética brasileira independente, livre de qualquer herança colonial que represente perda de identidade. Daí a intolerância que causou ressentimentos.

O caso Monteiro Lobato é, para nós, paradigmático porque antecipa uma perspectiva artística similar que fez com que o modernismo do nordeste só eclodisse plenamente - ou só fosse percebido como tal - com o romance regionalista de 30. As manifestações anteriores, por terem sido confundidas como contrárias à modernidade "desvairada", não foram assimiladas pela historiografia literária brasileira.

O modernismo paulista figura na memória nacional como um inexcedível núcleo do pensamento de vanguarda, excluindo de modo maniqueísta toda e qualquer oposição aos seus trejeitos, sob a pecha de passadismo. Por isso, convém equilibrar a balança assinalando que ele corresponde a um momento da história do país dominado pela chamada "política café com leite". As oligarquias e as elites quatrocentonas produziram seu contraveneno, representado pelas manifestações de rebeldia estética da Semana de Arte Moderna. Criouse toda uma mitologia de apanágio ao Modernismo do centro econômico do país, anulando qualquer significado possível a ser atribuído à construção da modernidade artística em outras regiões do país. Na Bahia, por exemplo, nós, bem intencion- 
dos intelectuais de província, fomos responsáveis por interpretar os avanços e recuos do pensamento artístico da década de vinte como a mais enfadonha forma de conservadorismo.

Como se sabe, a própria dinâmica social produz, em qualquer parte, seus mecanismos de conservação das estruturas envelhecidas e de irrupção das novas formas. Tanto no Nordeste patriarcal quanto no Centro Sul capitalista os padrões estéticos europeus mais tradicionais constituíam moeda de grande valor. A substituição automática das formas emboloradas, anteriormente trazidas da Europa, por todo e qualquer grito de rebeldia que atravessasse o Atlântico era a grande tentação dos jovens artistas brasileiros. Tanto lá, no Centro Sul, quanto cá, no Nordeste, o atraso com relação à modernidade européia era um fato sensível. As duas regiões do país reagiram de modo diverso e de acordo com fatores culturais distintos. Ao contrário do que afirmou Lobato em 1917 - contrariando o que demonstra sua obra - as artes não são regidas por princípios imutáveis, nem por leis fundamentais que não dependem da latitude nem do clima. As artes são parcialmente condicionadas antes que possam obedecer a princípios imutáveis. A grande metrópole econômica do país é marcada, para o bem e para o mal, por uma realidade diversa daquela constituída em outras latitudes.

É desse modo que a obra de Jorge Amado desenvolve, de forma conseqüente e definida, uma vertente identitária da nacionalidade destinada a substituir a figura do índio, idealizada por Alencar, por outros atores, incluindo a mistura 
de sangues dos diversos cantos do mundo. Desde os árabes, que aqui chegaram para mercar suas quinquilharias, até os africanos trazidos em porões de aviltantes navios. Assim tem lugar de relevo na obra amadiana, o negro real e palpável que conseguiu afirmar a sua cultura, a despeito do aniquilamento do sujeito propiciado pela escravidão. Centrando a noção de valor de um povo mestiço para além da história oficial, Amado realiza desde Tenda dos Milagres (obra que explicita as questões levantadas com exemplar picardia desde quando despiu a camisa-de-força do Partido Comunista), até a madura construção de obras como Tocaia grande e O sumiço da santa.

Desconstruir a herança colonial européia e fortalecer a auto-estima da gente mestiça - ou do povo brasileiro - é o que Jorge Amado começou a fazer, a partir dos anos 70, por entre as frestas da história contada e por entre as festas dos sentidos incendiados na tempestade do texto. O apimentado, o gorduroso e o farto uso de frutos africanos, ao contrário de diminuir o valor da obra amadiana, como queria uma prestigiada vertente da crítica universitária, vieram a se impor como elementos definidores de um valor identitário já simbolizado nas coisas da cozinha por Gilberto Freire.

Quando o escritor traça seu próprio caminho, muitos estudiosos de formação socialista passam a ver Jorge Amado como uma espécie de desertor da causa do proletariado. Depois de aderir, com fervor juvenil e sem nenhuma crítica, aos princípios do realismo socialista, ele se deixa tomar pelo desencanto e do desencontro que se apoderaram da 
esquerda após a necrose do totalitarismo stalinista. Os crimes do autoritarismo foram expostos aos olhos do mundo e, nesse balanço de perdas e ganhos, houve quem descobrisse que os fins não justificam os meios.

Outros, no entanto, continuaram impermeáveis ao senso do lugar comum: os fins não justificam. Mas continuaram usando todos os meios para chegar aos fins sonhados.

Considerado este quadro, por que os anos sessenta trouxeram a negação do valor da obra amadiana? Até a metade do século, o arrebatamento pelo seu texto era quase unânime, vindo, em seguida, um gradativo obscurecimento crítico. Nos anos setenta, esta obra conheceu verdadeiro massacre, tanto do ponto de vista político quanto cultural. No Brasil, a exemplo do que ocorreu nos Estados Unidos, setores envolvidos com questões raciais apontaram a valorização da mestiçagem no universo de Jorge Amado como mistura impura, ou como apagamento da pureza racial negra. (ÊEpa, rei! Este filme já passou em algum lugar. E deu no que não deu.)

De um lado e do outro, o mito da pureza étnica gera segregações. Não é exagero afirmar que a obra de Jorge Amado chegou a ser rejeitada por duas razões contrárias: de um lado, os feitores da pureza africana desconfiavam da construção romanesca de uma civilização negro-mestiça (vendo na mestiçagem o embranquecimento); do outro lado, arianos e quase-brancos não toleravam a elevação do negro e do mestiço à categoria mítica de herói incondicional (vendo na exaltação da mestiçagem a apologia de raças até então ocupantes 
de espaços exclusivamente periféricos).

A valorização de uma mitologia crioula pela obra amadiana punha em pé de igualdade velhos mitos europeus e novos mitos afro-brasileiros. Valores, quer sejam politicamente corretos ou não, machistas, patriarcais, ou desconstrutores do estabelecido - valores integrantes dos costumes crioulos da Bahia - constituíram a isto que chamo de "mitologia crioula" da obra amadiana.

Sabemos que a cultura impõe preceitos e preconceitos, mutáveis em vários tempos. Se, hoje, a academia revaloriza a obra de Jorge Amado, convém lembrar que, há dez ou vinte anos atrás, os cursos de Literatura das universidades baianas, seu lugar de origem, não dedicavam nenhuma disciplina ao estudo dos livros do maior contador de histórias da raça brasileira.

Hoje, estudos de gênero admitem observar o lugar da mulher nos romances de Jorge Amado, estudos étnicos percorrem a construção do orgulho negro e mestiço, estudos culturais encontram importantes estratégias de descolonização do pensamento.

Mas por que a obra desse contador de histórias da civilização mestiça atravessou turbulências e calmarias, quedas e baixas na bolsa de valores da crítica da cultura?

Uma hipótese é que isso decorre do fato de Jorge Amado ter sido, de início, um fiel tradutor dos princípios e mandamentos do marxismo soviético, para em seguida abandoná-los em favor do flerte mais aberto com os festins da 
pequena burguesia. Se o romancista dos primeiros livros escrevia para comunista nenhum botar defeito, ao se desligar das imposições do Partido, ele experimentou a liberdade absoluta de criar, renunciando inclusive ao princípio segundo o qual a literatura deve pôr em primeiro plano a sua função de construtora e forma do conhecimento. Livre para criar, Amado procura a antítese da obra engajada: a literatura feita para divertir.

Por entre o riso solto e a narrativa de aparência meramente anedótica, o romancista produz o melhor da sua obra, ocultando e entremostrando, velando e revelando o compromisso social por entre as dobras de um tecido alegre. Do discurso marcado pelo cumprimento de tarefas partidárias, evoluiu para um discurso pleno de sentidos, armadilhas, sugestões e arremedilhos.

Ora, o leitor habituado ao romance de tese, onde a mensagem política sobrepujava o jogo do prazer, veria o novo figurino amadiano com a mesma suspeita dirigida à figura intelectual do ex-comunista. Deixar o Partido por discordar das suas práticas era um fato considerado equivalente à traição aos seus princípios. Daí a metralhadora giratória do patrulhamento ter varrido a obra de Jorge Amado, estimulando-o a aprofundar o distanciamento com as práticas ditadas pela estética marxista dos anos de ferro.

Voltando ao título aqui proposto, podemos concluir que as diferenças entre o modernismo paulista e a olvidada modernidade nordestina permitiram não só a fixação dos tra- 
ços mais nítidos do Romance de 30 quando de obras como a de Jorge Amado, cujos cem anos o Brasil e o mundo agora comemoram, em eventos como este.

Este trabalho surge pelo honroso convite da doutora Sudha Swarnakar para proferir a palestra de abertura do Colóquio JORGE INTERNACIONALMENTE AMADO, na Universidade Estadual da Paraíba. Embora conhecesse a professora Sudha através do seu trabalho desenvolvido no Brasil, foi através do doutor Humberto Oliveira que tive oportunidade de conhecer - lhe e vir a participar desse evento.

\section{Referências}

ALENCAR, José de. Como e porque sou romancista: autobiografia literária em forma de carta. Porto Alegre: Mercado Aberto, 1998.

ALVES, Ívia. Arco \& flexa: Contribuição para o estudo do modernismo. Salvador: Fundação Cultural do Estado da Bahia, 1978.

AMADO, Jorge. Tereza Batista cansada de guerra. Rio de Janeiro: Record, 1972.

AMADO, Jorge. Tocaia grande: a face obscura. Rio de Janeiro: Record, 1984. 
AMADO, Jorge. O sumiço da santa. Rio de Janeiro: Record, 1988.

AMADO, Jorge. Navegação de cabotagem: apontamentos para um livro de memórias que jamais escreverei. Rio de Janeiro: Record, 1992.

ANDRADE, Oswald de. Ponta de lança. 2. ed. Rio de Janeiro: Civilização Brasileira, 1971.

ARCO \& FLEXA: edição fac-similar. revista literária de 1928/1929, Salvador, Fundação Cultural do Estado da Bahia, 1978. (n 1, 66 p., n., 2/3, 70 p., n. 4/5. 90 p.).

CANDIDO, Antonio. Literatura e sociedade. 5. ed. São Paulo: Nacional, 1967.

DELLA VOLPE, Galvano. Sociologia. São Paulo: Ática, 1980.

FREYRE,Gilberto. Tempo morto e outros tempos. Rio de Janeiro: J. Olympio, 1975.

MONTEIRO LOBATO. Paranóia ou mistificação [Crítica originalmente publicada em dezembro de 1917]. Idéias de Jeca Tatu. São Paulo: Brasiliense, 12. ed. 1967, p.59-65. 
MOTA, Carlos Guilherme. Ideologia da Cultura brasileira. 3. ed. São Paulo: Ática, 1977.

SCHAFF, Adam. História e verdade. São Paulo: Marins Fontes, 1978.

SEIXAS, Cid. Jorge Amado: da guerra dos santos à demolição do eurocentrismo. Salvador: CEDAP, 1993.

SEIXAS, Cid. Modernismo e diversidade: impasses e confrontos de uma vertente regional. Légua $\&$ meia- Revista de literatura e diversidade cultural. Feira de Santana: UEFS, v. 3, n. 2, 2004, p. 52-61.

SEIXAS, Cid. Triste Bahia, oh! Quão dessemelhante. Notas sobre a literatura na Bahia. Salvador: EGBA / Secretaria da Cultura e Turismo, 1996. (Coleção As Letras da Bahia).

SERRA. Ordep. Jorge Amado, sincretismo e candomblé. In —: Águas do rei. Petrópolis: Vozes, 1995, p. 289-360. 


\section{Her tongue is tied not her eyes: Amado's experiment with non verbal language in Tereza Batista Cansada de Guerra}

Sudha Swarnakar

\section{Abstract}

Brazilian critics as well as the academics in general seem to show a sort of dislike for Amado's language. Often the ironical comment or negative tone does not suppress their disapproval of his use of language, ignoring the lyricality, simplicity and stylistic innovation in his novels for instance in Terras do sem fim, Gabriela, cravo e canela or in Tereza Batista Cansada de Guerra. Present paper focuses on female silencing and the use of non verbal language in Tereza Batista to show how this prolific Brazilian writer kills two birds with one stone. On one hand it shows Amado's command on language and on the other hand it shows how Amado offers a verbal meaning through a non verbal mean making, this otherwise "powerless woman" the victim of social and sexual abuse, an "intelligent" woman who learns to speak through her eyes. Her tongue is tied not her eyes, the most powerful tool her creator could offer her to speak.

Key Words: non verbal language, Jorge Amado, Tereza Batista's eyes. 


\section{Resumo}

Críticos brasileiros, bem como os acadêmicos, em geral, parecem apresentar uma espécie de antipatia para a linguagem de Amado. Muitas vezes, o comentário irônico ou tom negativo não suprime a sua desaprovação da sua língua, ignorando a simplicidade e inovação estilística em Terras do sem fim, Gabriela, Cravo e Canela ou em Tereza Batista Cansada de Guerra. Este ensaio centra-se em silêncio feminino eo uso de linguagem não verbal em Tereza Batista para mostrar como este escritor brasileiro prolífico mata dois coelhos com uma cajadada só. Por um lado, mostra o comando de Amado sobre a linguagem e, por outro lado, mostra como Amado oferece um significado verbal através de um meio não verbal transformando essa "mulher impotente" vítima de abuso sexual e social, numa mulher "inteligente" que aprende falar através de seus olhos. Sua língua está amarrada não seus olhos, a mais poderosa ferramenta que seu criador poderia lhe oferecer a ela para falar.

Palavras-chave: linguagem não verbal, olhos da Tereza Batista, Jorge Amado 
Most of Amado's novels are knitted around characters who present a certain class or group stigmatized by social and cultural elites. Hence, he uses the vocabulary normally considered inappropriate or obscene, but which is strongly marked by situational factors. A number of Brazilian critics as well as the academics in general have expressed their concern about Amado's language and there is a huge body of criticism about Amado's language. ${ }^{1}$ Often the ironical comment or negative tone does not suppress their disapproval of his language use, ignoring the simplicity and stylistic innovation in Terras do sem fim, Gabriela, cravo e canela or in Tereza Batista Cansada de Guerra. His language that appears with naturalness in the texts, appropriately presents the speech of the lower classes. My concern here, however, is not to discuss Amado's language but the lack of language, the absence of speech as I cast a glance at his central character Tereza Batista.

Comparing woman's situation with the colonized, Gayatri Spivack (1988) sees woman in more underprivileged condition and says "[...] the ideological construction of gender keeps the male dominant. If, in the context of colonial production, the subaltern has no history and cannot speak, the subaltern as female is even more deeply in shadow...." The discussion here will show how this subaltern

1 A wide discussion on Amado's language is offered by Paulo Tavares (1982), Álvaro Cardoso Gomes ( 1988) ABDALA Jr., Benjamin Abdala Jr. (1999) and others. 
woman comes out of shadow and makes herself audible and visible.

Amado depicts her in three different situations. First, through the master-slave relationship between Justiniano Duarte da Rosa and Tereza Batista. Secondly, during her life with Emiliano Guedes, she lives as a kept woman of the most powerful patriarch of the region. And finally, in her love relationship with Januário Gereba which offers her recognition and fulfillment. The love episode between two is short but sufficient to explore her situation in this love relationship. The text in this part shows that Tereza does not lack feminine qualities: she fights like a man but she listens like a woman. As the narrator says: "Ele falando, ela ouvindo" (AMADO, p 16). However, now she listens not by force, not because of her admiration, but lovingly "ouvindo as ondas do mar, o vento nas velas pandas, o marulho nos búzios" (AMADO,p. 16).

Contrary to Gabriela, in whom Amado creates an icon of Brazilian beauty and youth, Tereza is presented as a woman who is seen, used and abused as female body. First, she is presented as an adolescent girl and then as a woman but in both depictions she does not fit in the long line of sensual women of Amado's world. In the part of novel that presents her as a adolescent girl there is no reference to her beauty:

Pela janela da saleta pobre o capitão brechava o olho cúpido na menina 
[...]. Parecia um moleque, o corpo esguio, os peitos apenas despontando na chita da blusa, o saiote no meio das coxas longas. Magra e comprida, ainda tão sem jeito de mulher $[\ldots]$

(AMADO, p.60)

It is only the body, the female body of a girl or a young woman which remains as a haunting echo of the more subtle reduction of woman, reduced to body parts charted in the proceeding, not as a glorified image of femininity one sees in the later part. Chapter three of Part One "A Estreia de Tereza Batista no cabaré de Aracaju" presents her in a cabaret where Saraiva, the poet, exhibits her to his friends, “- Artista, admire o supremo modelo, digna de Rafael e Ticiano [...] a dama mais leve, de ouvido mais fino" (AMADO, p. 6).

The portrait of Tereza's extraordinarily lovely body described above does not provide a complete picture of her beauty. The description here is governed tellingly by the repeated use of word "dama" which constructs her as an alluring object of desire. As the story develops, other attributes are allotted; her face, her teeth, the skin color are presented as the mark of physical beauty but most importantly her tongue, which is necessary for speech, is absent.

In her first physical contact with a man it is her female body and not her beauty, her femininity or her speech 
that matters. Although Tereza occupies a prominent place in the plot, an acute sense of absence of her speech takes over the reader because her acts are described by multiple narrators more than by her own verbal expression or monologues. In Bakhtin's point of view such characters are made subordinate to the control of the author as the narrative voice leaves them powerless but I argue that in case of Tereza Batista, Amado does not snatch away her power of speech. Though in whole novel he presents her as someone who is silent but I argue she is not muted she speaks through her eyes.

Spivack (1988) observes "the relationship between woman and silence can be plotted by women themselves" in literary world we see it is plotted more by the authors than by the characters as it is the author who is troubled by their silence. In a number of examples of literary representation of woman the power she gains is through her speech or her action and often it is not she who speaks but the authorial narrator. In Tereza Batista Amado creates an icon of female power in a subaltern woman who does not need speech to express her feelings or to exercise her power. As further discussion will show life teaches her to be silent.

Justiniano Duarte da Rosa so overpowers and dominates her through his brutality that for ever she shuts her mouth. He conquers her body and takes his pleasure from her making her mute for ever. The lengthy descriptive passages, describing the rape of Tereza Batista in the novel, give the glimpse of brutality to which girls like Tereza were submitted. 
After going through such an experience can she get her voice, can the subaltern speak? Yes, she will speak, similar to Philomina in Ovid's Metamorphosis or the Hindi poetess Meera, Tereza acquires a different medium to speak out. ${ }^{2}$ Amado delineates a northeastern woman in Tereza who by social law is forced to keep her mouth shut but he does not present a mute woman as he skillfully gives her those expressive eyes to reveal her feelings. Through most of the novel she keeps quiet but her sentiments are revealed through her eyes. In a number of scenes the narrator calls attention to her eyes, exhibiting her feelings and reactions, transmitting messages more powerfully than the words could do.

The first time one meets her she appears to be a happy child 'suor brilha no rosto de cobre, a alegria nos olhos' (AMADO, p. 62). ${ }^{3}$ Soon this happiness is transformed into anger as the narrator says: '[e]la se debatia, tentava morder, os olhos em fogo' (p. 69). However, this fire is soon cooled down by the violence she goes through in Justiniano's

2 For a detailed discussion of Philomela and Meera see Swarnakar, Sudha "Female Silencing in Mythology and in Modern Literature: Ovid's Philomela and the Hindi Poetess Meera" em Sudha Swarnakar and Maria Marta dos Santos Silva Nobrega (org.) Cartografia da Violência: Ensaios Comparativos. João Pessoa: Idéia, 2008, pp. 29-43.

3 For emphasis, the part of text with specific reference to her eyes has been marked with bold letters. 
farm house. Once in Justiniano's house, her eyes assume a fixed expression as if the young and vibrant girl is frozen. The circumstances bring big change in her outlook. From a sweet, innocent girl she is transformed in person full of hatred. As the narrator says: '[n]os olhos de Tereza apenas ódio, mais nada' (p. 101). However, the strength to oppose and hatred in Tereza's eyes disappear as she sees Justiniano with an iron and burning coal. I will not repeat the scene (Part Two "A menina que sangrou o capitão com a faca de cortar carne seca", Chapter 18) here, as I have discussed in length in other articles, yet I will say that it is one of the most powerful examples of Amado's language. Similar to Edgar Allan Poe or Lawrence Amado's language flows with such power that the distance between verbal and visual almost disappear. The reader not only read the depiction of brutality but feels, senses and smells the burning of tender body part. This seems to be few occasion where Tereza is given voice to implore. But the speech is taken over again by her powerful eyes and the narrator does not let it pass unobserved as he says "Arregalaramse os olhos de Tereza" (AMADO, p.107).

Viewed from a feminist perspective, her silence during this period is a clear sign of her resistance against patriarchal power. For two months the force of brutality keeps her quiet and she endures his violence without uttering a single word. As Miécio Táti observes: “[...] mulherzinha persistente, sofrida não se discute." The "epistemic violence" she is submitted to in this sexual initiation has profound effect on 
young Tereza and she is snatched off of her speech for ever. At a very early stage in her life she learns to obey the social norms. She knows that her class, her race and her sex prohibit her to speak, to speak against the oppressors and the political power, against the injustice and the exploitation. She learns to speak herself out without uttering a single word.

During this period hatred and fear become the synonym for love and sex. It is Daniel with whom she learns the first lessons of love and suddenly 'dentro de seu peito alguma coisa explodiu e os olhos [...] umedeceram-se [...]' (AMADO, p.144). This pleasure has no verbal expression it has to be shown through her humid eyes. After her affair with Daniel when Justiniano takes her, he is taken by Tereza, the 'donzela', and is pleased by her 'new virginity'. He decides she deserves 'duas argolas' but he does not see her face and the 'lampejos de ódio nos olhos de medo, negros de carvão' (p.169). The hatred reaches its climax as she attacks Justiniano. The text is very well structured here as it shows the shift in power from male aggressor to subaltern woman. He turns to look at her and sees 'Tereza de pé, a mão erguida, um clarão nos olhos, a beleza deslumbrante e o ódio desmedido' (p.176). The verbal language has no space here as the hatred which makes her kill him could be expressed only through eyes.

During his first meeting with Tereza in police custody on charge of murder Emiliano Guedes, the powerful patriarch of society, does not see her as a beautiful young 
woman but as a victim and is taken by sympathy for her. It is her eyes that mark her presence more than her youthful body. He feels pity for her as he does not fail to note the "fulguração dos olhos negros [...]" (AMADO, p.123).

The life with Emiliano brings her happiness and makes her relax, as the narratorial comment shows: [...] agora o óleo do prazer banhara-lhe rosto e corpo, o gosto e a alegria do amor acenderam-lhe nos olhos aquele fogo do qual o doutor Emiliano Guedes percebera o fulgor meses atrás' (p.172). As the above passage shows that even the pleasure of being happy in love, being treated well and having a comfortable life with Emiliano Guides does not make her open her mouth, she only speaks through her eyes. She is depicted as a silent listener, rarely giving her opinion. However, in contrast to her relationship with Justiniano it is not because of force or brutality but because of her admiration for him. After her brutal possession by Justiniano she finds solace in this master-pupil relationship which develops between them and transforms her into his devotee. From a subjugated slave she is changed into the body of a woman who behaves with the delicacy and comprehension of a lady and as a lady, when she comes to know about the sexual scandals of Aparecida, Emiliano's daughter, she does not encourage the gossip and keeps the secret.

In an episode, in Chapter 19 in Part Four "A noite em que Tereza Batista dormiu com a morte", Amado constructs a scene where she ascends from womanhood to motherhood. 
After she comes to know that she is pregnant she becomes extremely happy but she does no express herself through words, her joy is expressed through her eyes 'os olhos negros de Tereza cismarentos, absortos' (p.264)

The second half of Tereza's portrayal at this point offers an altogether different image of her feelings. The use of verb 'quite' gives way to phrases dominated instead by 'olhar'. She keeps quiet but her sentiments are revealed through her eyes. As Juarez de Gama Batista observes, her whole personality is revealed "sempre através da iluminação dos olhos, do olhar $[\ldots] .^{34}$

The scene where Amado presents her after Emiliano's death she becomes the focus of both narrator and the characters. The doctor who comes to attend Emiliano Guedes seems to be more worried about social aspect then Tereza but Nina, the maid servant observes her carefully and expects to see her crying, her eyes full of tears. Tereza however, is perplexed; she cannot cry and leaves the house with 'olhos secos' (AMADO, p.316). Her pain at such an occasion could not have been expressed through her cry. It had to be expressed internally and silently as it makes the reader see the power

4 Batista seems to be the only critic who in his brief essay on Tereza Batista touches on a number of important issues which I explore in my thesis and also in my articles as he just mentions these points never goes in depth, makes no effort to analyze or discuss them. Most of his observations, though crucial to understand this novel, are made in a passing way in one or two sentences. 
of her dry eyes and how they speak more powerfully.

Tereza's silencing offers an opportunity to show Amado's command and skillful use of a language that is not verbal. As we see the novel is full of examples where he offers a verbal meaning through a non verbal form, the "eye language" that helps him to empower this otherwise "powerless woman" the victim of social and sexual abuse as a "tactful" woman who learns to speak in a way that is more effective. Her eyes are the most powerful tool her creator could offer her to speak. The beauty and skillful use of this non verbal form in Amado make it hard to ignore this silent but strong woman and also to disagree with critics who overlook this stylistic experiment in Amado's language.

\section{References}

ABDALA Jr., Benjamim. O romance social brasileiro Margens do texto. São Paulo: Scipione, 1999.

AMADO Jorge. Tereza Batista cansada de guerra. 29. ed. Rio de Janeiro: Record, [s/d].

GOMES, Álvaro Cardoso. Literatura Comentada. São Paulo: Nova Cultura, 1988.

BATISTA, Juarez de Gama. A contra prova de Tereza. p.178. 
SPIVACK, Gaytri C. Can subaltern speak? In Cary and Lawrence Grossberg (eds.), Marxism and the Interpretation of Culture. London: Macmillan, 1988.

SUASSUNA, Luciano. O Brasil sem Jorge Amado. Isto é Gente -13/ago/2001, p. 8.

SWARNAKAR, Sudha. Female Silencing in Mythology and in Modern Literature: Ovid's Philomela and the Hindi Poetess Meera. In Sudha Swarnakar and Maria Marta dos Santos Silva Nobrega (org.) Cartografia da Violência: Ensaios Comparativos. João Pessoa: Idéia, 2008.

TÁTI, Miécio. Teresa de guerra, uma nova mulher dos ricos desvãos Amadianos. In Journal do Brasil. Rio de Janeiro, 22 Jan 1973, p.3.

TAVARES, Paulo. O Baiano Jorge Amado e sua obra. Rio de Janeiro: Record, 1982. 


\section{Direito e literatura: Tereza Batista Cansada de Guerra e a atual legislação brasileira protetiva da mulher}

Lucira Freire Monteiro

\section{Resumo}

Considerando que a literatura como arte pode também ser objeto de reflexão do direito, na medida em que permite o dimensionamento da realidade segundo valores estéticos de equilíbrio e forma que o direito também assume, a relação entre Direito e Literatura pode ser considerada em três vertentes: Direito da Literatura, Direito como Literatura e Direito na Literatura. O que se propõe neste artigo é tomar essa terceira vertente, sem menosprezo às demais, traçando uma revisão legal da realidade esboçada no romance Tereza Batista, Cansada de Guerra, particularmente em torno do Estatuto da Criança e do Adolescente Brasileiro (Lei no 8069 de 13 de julho de 1990) e Lei Maria da Penha (Lei no 11.340 de 7 de agosto de 2006), considerando que a literatura seja um âmbito de referenciação da e para a juridicidade dos casos concretos. À luz de preceitos jurídicos válidos em nosso país o romance de 1972 é passível de reconhecimento de questões relacionadas ao gênero feminino mesmo na atualidade, em que a problemática do abandono material e intelectual repercute negativamente como afronta a direitos fundamentais e reafirma o caso concreto na ficção literária. A abordagem ao 
direito na literatura tem denotado interesse em ascensão tanto pela interdisciplinaridade no âmbito acadêmico quanto pelo caráter pedagógico de mobilização do cidadão comum em torno do direito e da justiça. A festejada obra de Jorge Amado prima pela veemência de uma realidade nordestina, pelo que Tereza Batista Cansada de Guerra é um caso exemplar.

Palavras-chave: Direito. Literatura. Ficção. Realidade. Jorge Amado. Tereza Batista.

\section{Introdução}

A consideração de que o direito figura como uma daquelas instituições que se realizam por meio da linguagem serviu como aproximação de estudiosos do fenômeno cultural e desencadeou um movimento interdisciplinar que abriu passagem na exclusividade dogmática do direito para a narrativa como forma jurídica. Esse movimento conhecido como Direito \& Literatura (Law as Literature) toma três principais tendências, considerando o direito da literatura, com abordagens em torno da responsabilidade dos autores, dos direitos de propriedade intelectual, da liberdade de expressão, da regulação dos meios de comunicação, principalmente; o direito como literatura, voltado para a semântica da lei, a estética discursiva dos tribunais, a linguagem policial e a lógica da argumentação jurídica; e, o direito na literatura, focando as representações que se fazem em torno do direito e da justiça na literatura especializada em seus diversos cam- 
pos de abrangência e realização, ou na literatura de cunho informacional (seja de entretenimento, de esclarecimento, de ideologização), incluindo-se também na literatura ficcional (de entretenimento, de ideologização).

$O$ vetor de aproximação entre os críticos da verdade jurídica está na importância que o significado e a interpretação têm para o direito, e na sua capacidade demiúrgica, capaz de fundar realidades cuja existência é eminentemente subjetiva. Tem-se por certo que esse poder de criar conceitos como "culpa", "responsabilidade", "propriedade", "crime", que são criações linguísticas do direito, faz o direito passar da abstração para uma existência real, permeando assim o cotidiano de todas as sociedades. É no cenário da sua efetiva prática que os indivíduos exercitam a capacidade argumentativa e fazem do direito um instrumento de justificativas das necessidades e de convencimento da sua relação com a justiça.

Nisto é preciso lembrar como fez Habermas (2004, p.253) ${ }^{1}$, referindo a mobilidade histórica das sociedades, que toda ordem jurídica é também expressão de uma particular forma de vida, e não apenas o espelhamento do teor universal nelas inscrito. Como ciência que reflete e interfere na realidade os conceitos e institutos jurídicos acompanham a realidade social, permitindo-se variar conforme as alterações

1 HABERMAS, Jurgen. A inclusão do outro. 2.ed. São Paulo: Edições Loyola, 2004. p. 253. 
culturais, antropológicas ou ambientais. Também nessa direção lembramos que o direito tem a sua renovação enquanto narrativa $^{2}$, não se configurando apenas como ordem, pois ao considerarmos a ordem como uma informação ela só existe até quando não tenha sido processada, racionalizada e assimilada. $\mathrm{Na}$ medida em que passa para o domínio do pensamento vivo, como fenômeno da sociedade, o direito se confunde com a própria sociedade, como pensa e age, constituindo tipo narrativo, que vivifica a ordem e alimenta a tradição jurídica.

Assim, o aguçamento da crítica na formação do jurista comprometido com as questões sociais surge, como chamou a atenção Santos (2005), não apenas de "situações ou condições que nos suscitem desconforto ou indignação e nos produzam inconformismos"3 sobre o imediato que nos rodeiam, pois o jurista atento às questões contemporâneas não pode furtar-se ao entendimento daquela conexão entre o pensamento de hoje e o seu nascedouro, pelo que qualquer

2 A informação reduz-se ao instante em que é nova. Vive apenas nesse instante, precisa entregar-se inteiramente a ele, e, sem perda de tempo, comprometer-se com ele. Com a narrativa é diferente: ela não se exaure. Conserva coesa a sua força e é capaz de desdobramento mesmo depois de passado muito tempo." Walter Benjamin. O narrador. In: Textos escolhidos. São Paulo: Câmara brasileira do livro, 1983, p.62.

3 SANTOS, Boaventura de Sousa. A crítica da razão indolente: contra o desperdício da experiência. 5. ed. São Paulo: Cortez, 2005, p.23. 
das formas de expressão social remete a um esclarecimento, um testemunho, uma prova. Importa ressaltar que em nome de uma tecnocracia jurídica não se pode limitar a expansão dos fundamentos culturais do direito sob pena de disseminar uma visão equivocada sobre ele. Muitas vezes em razão da cegueira e ignorância que o demasiado racionalismo científico foi/é capaz de provocar, como nos fez ver Saramago ${ }^{4}$, justifica-se uma objetividade para o direito como se ele não fosse afeto às questões concretas da sociedade.

Alias a realidade tem formas variadas de interferir nas mentes e na direção que os indivíduos dão à história da sociedade. Essas múltiplas formas de ver e contar sobre os fatos relevantes da existência humana são repassadas à posteridade através dos mitos, das lendas, das crenças, e criam valores, verdade descritivas do mundo. A tradição oral foi importante para a organização de todos os grupos humanos. A escrita, por sua vez formalizou o pensamento e a lógica de educar as gerações, criou canônes e estabeleceu regras. A literatura tornou-se com isto um repositório de experiências capazes de fornecer de várias maneiras os valores significativos de convivência humana.

Nisto a integração do direito com a literatura ficcional constitui uma valiosa ferramenta para analisar valores jurídicos segundo as representações e a imaginação

4 SARAMAGO, José. Ensaio sobre a cegueira. São Paulo: Companhia das Letras, 1995. 
legal ${ }^{5}$. Na esteira de François Ost as relações entre Direito e Literatura não se prestam a uma mera forma de explicação, mas a uma hipótese interpretativa, como tentativa de relançar o pensamento num jogo de remissões sempre recomeçando ${ }^{6} \mathrm{O}$ direito como um fenômeno social por excelência, às vezes "parece não estar organizado para ser socialmente inteligível... A linguagem da lei (e aqui me refiro, quer à linguagem legislativa, portanto, escrita, quer à linguagem legal aplicada oralmente na sala de audiências) é diferente da linguagem espontânea do dia-adia." Embora essa consideração privilegie na concepção de direito a presença da norma, sabemos que o direito tem uma abrangência e uma dinâmica que a norma por si só não possui. $\mathrm{O}$ direito perpassa a maioria das relações humanas, por isso está atrelado à cultura, às formas de entender e agir cotidianamente.

No universo acadêmico os estudos culturais e o pensamento jurídico crítico convocam variadas dimensões e

5 James Boyd White. The Legal Imagination: Studies in the nature of legal thought and expression. Chicago: University of Chicago, 1985.

6 OST, François. Contar a Lei. As fontes do imaginário jurídico. São Leopoldo: Unisinos, 2004, p.386.

7 RODRIGUES, Maria da Conceição Carapinha. Discurso judiciário, comunicação e confiança. In O discurso judiciário, a comunicação e a justiça. V Encontro anual do conselho superior da magistratura. Coimbra: Editora Coimbra, 2008, p. 33 -65. 
questões da vida social ${ }^{8}$, quais sejam questões éticas, ideológicas, sociológicas, existenciais, que mesmo relacionadas a uma compreensão do direito não são trazidas de modo conclusivo, justamente para permitir uma perspectiva de abertura do direito que o discurso tradicional se encarregou de dificultar, especialmente sob o argumento da universalidade, centralidade e antecedência. Exige-se cada vez mais na formação jurídica o trânsito por outros campos científicos que auxiliem na visão crítica da realidade e do sentido como o direito é experimentado socialmente. Isto inclui intercorrências com a geografia, a antropologia, a arte, para além da já sabida relação com a história, a política e a filosofia.

A estética do direito visando ao equilíbrio das relações sociais e da autocompreensão individual, muitas vezes é rechaçada pela sua forma. Formalismo e formalidade que o caracterizam de modo muito particular permite mesmo uma

8 Encontramos em Marta Nussbaum. Poetic justice: the literary imagination and public life. Boston: Boston Press, 1995, uma análise da contribuição da literatura no desenvolvimento de uma compreensão em torno do direito, especialmente entre estudantes e em favor da democracia, não como um movimento exclusivamente ideológico, mas como substrato para uma efetiva e salutar prática do direito. Para ela, a imaginação literária contribui para uma postura ética que inclui a preocupação com o outro, desconhecido e distante, sobretudo quando a mentalidade econômica tem concorrido para o individualismo e para a dificuldade de se viver humanamente com sentido. Sua abordagem à ética do direito na literatura considera que esta favoreça a abertura à alteridade e concorra para o conhecimento do outro como sendo o real sentido do direito. 
visão ampliada em torno da estética. Muitas vezes a linguagem da lei e a linguagem dos acadêmicos criam uma ojeriza intelectual à acolhida da sua estética. Há muitas palavras ocas de emoção na lei, mas não no direito. A palavra da lei é revestida de ordem, por isso não pode ser expressa nem por ódio nem por paixão. A palavra do jurista no trabalho judicial é voltada para o convencimento, a defesa, a contestação e o julgamento, atribuindo significados que vão para além do sentido empregado, sempre implicando na inclusão de valores.

Não obstante a concretude do direito seja alcançada nas relações humanas, sociais e políticas, o direito não pode ser equiparado nem à arte (de interpretar) e nem à matemática (de quantificar), mas como uma instância de civilidade em cuja pedagogia o afeto, a solidariedade e a autoridade devem se manter objetivamente. Por isso a linguagem jurídica precisa acolher a diversidade de testemunhos, seja para legislar ou julgar o caso concreto, seja para se manter fiel à história e à cultura. Tanto assim a experiência e a memória são fundamentos de todo o pensamento jurídico e nisto a literatura popular ou especializada são igualmente importantes à lógica da interpretação jurídica.

\section{Jorge Amado, um contexto em aberto para compreender o caráter pedagógico do direito}

Considerando que o direito não surge dos fatos propriamente ditos, mas das narrativas, posto que estas deem ao fato o sentido que lhes reveste ou não de juridicidade, 
e que "a interpretação artística sempre pretende identificar um pensamento consciente específico que coordena toda a orquestração na mente do autor quando este diz, escreve ou cria sua obra", tentaremos extrair pontos de interseção entre a 'realidade' vertida no cordel Tereza Batista Cansada de Guerra $^{10}$ e alguns princípios jurídicos, pressupostos na 'Lei Maria da Penha' e no ECA.

A forma como Jorge Amado busca em Tereza Batista envolver o leitor pela relação que faz entre a personagem e situações atemporais e locais, embora mencione localidades sergipanas e baianas, evoca o reconhecimento como elemento de possibilidade, leva a um entrosamento do leitor com a sua narrativa de modo a suscitar a ideia de veracidade de seu 'relato'. Nisto a hermenêutica filosófica de HansGeorg Gadamer ${ }^{11}$ faz ver que a compreensão engloba toda

9 DWORKIN, Ronald. O Império do Direito. São Paulo: Martins Fontes, 1999, p.67 e seguintes. Refere o autor: “ Quero dizer que uma interpretação é, por natureza, o relato de um propósito; ela propõe uma forma de ver o que é interpretado - uma prática social ou uma tradição, tanto quanto um texto ou uma pintura - como se este fosse o produto de uma decisão de perseguir um conjunto de temas, visões ou objetivos, uma direção em vez de outra. Essa estrutura é necessária a uma interpretação mesmo quando o material a ser interpretado é uma prática social, mesmo quando não existe nenhum ator real cuja mente possa ser investigada".

10 AMADO, Jorge. Tereza Batista cansada de guerra. E-book digitalizado por Argo3nauta. Baixado em 25 de junho de 2010.

11 GADAMER, Hans-Georg. Verdade e método I: traços fundamentais de uma hermenêutica filósofica. Petropólis: Vozes, 2004. 
experiência e autoconsciência que é capaz de assumir o existente humano. O testemunho que é invariavelmente produzido segundo representações constitui uma narrativa, como ponto de vista referenciado na experiência ou na tradição oral e material. O ‘testemunho' trazido pelo autor fomenta tanto a dubiedade quanto a possibilidade, daí servir de elemento complementar, corroborador na convicção sobre as experiências de vida dos personagens.

Talvez se destaque uma predisposição à parcialidade do testemunho do autor somente justificada na clareza da percepção, na certeza da presença e no empenho pelo convencimento. Jorge Amado é contador das aventuras populares, parece não se ater às reflexões filosóficas, ao discurso político ideológico, todavia o esboço de realidade que oferece é passível de valorações e ratificações. Não é à toa que enfatiza matizes de feminilidade, machismo, conservadorismo, coronelismo, enfim caracterizações que ele não relaciona explicitamente como problemáticas sociológicas, mas leva o leitor torcer em apoio a alguma causa e repúdio a outras. Nesse passo configura a abertura do contexto já que assim desestabiliza a finitude dos personagens consoante a última linha do folheto, uma vez que a forma como os descreve e as suas aventuras permite o reconhecimento da humanidade que o leitor pode reconhecer e até compartilhar.

Nessa direção Amado fala de um mundo de humanidades, tal como pede o direito. Assim é que tanto quanto a literatura é capaz de despertar para uma compreensão sobre 
o humano que há nos personagens, também o direito projeta essa mesma compreensão do humano, em sua forma de interpretação da realidade sob a sua própria lógica. O sentido do direito está em possibilitar a passagem da condição meramente antropológica para a condição de civilidade, nos dizeres de Castanheira $\mathrm{Neve}^{12}$. A literatura como ferramenta de compreensão de sentido para o direito não pode se firmar apenas na transposição de um contexto para as preocupações do presente, mas buscar nas experiências narrativas do passado um horizonte de sentidos. Uma "fusão de horizontes" que parte da hipótese segundo a qual um âmbito da realidade constitui um dado desde um ponto determinado da história como um passo no trabalho da compreensão, crucial para abrir-se um novo horizonte no presente.

Os recursos como visores desse horizonte não inviabilizam a interpretação, mas auxílio. Assim a edição que serviu de fonte para o presente ensaio apresenta não apenas relato, mas também imagens como descrições ou testemunhos, recursos complementares, elucidativos da narrativa. No direito, ambos são recursos de provas de legítima validade, tanto assim podemos lembrar o retrato falado, cuja construção corrobora com a descrição ou narrativa da testemunha, ou da vítima ou da parte processual interessada, e que Jorge Amado utiliza para orientar o juízo criativo do

12 NEVES, António Castanheira. O direito como alternativa humana. Digesta I. Coimbra: Coimbra, 1995. 
leitor como um julgador que coleta provas e tem ali subsídios que substanciem as suas conclusões.

Alias o cordel é revestido de elementos tão pedagógicos quanto sociológicos, utilizando de normas cultas na estrutura gramatical lançando mão da simploriedade das aventuras do povo. Em sua tradição literária dissemina valores jurídicos, políticos, crenças e modos de agir. Esta dimensão está presente em Teresa Batista (TB) como uma estratégia de ratificação dos fundamentos das suas experiências, isto é como uma decisão por 'contar' sobre um modo de vida que é facilmente reconhecido por qualquer pessoa. Nisto fornecendo todos os disparates possíveis nas relações humanas ${ }^{13}$ Caracteristicamente o formato xilogravura que é utilizado, na literatura de cordel suscita a subjetividade em seu aspecto mais criativo. As ilustrações de Calazans Neto constituem um aparato colado à imaginação do leitor, carimbando imagens cabíveis a qualquer tempo, ratificando a ideia de ficção, cevando-nos a afirmar que fotografias não calhariam à imaginação criativa da forma como o cordel remete.

Escolha deliberada que viabiliza a abertura do contexto, isto é a atemporalidade e a recorrência. Escrito há quarenta anos TB ainda chama a atenção sobre a referenciação da narrativa para a juridicidade de casos concretos.

13 Weisberg Richard chega a conceber a literatura e o direito em unidade, guardadas as devidas diferenças, quando afirma: "law and literature, for all their disparities, are one". 
Pode-se saber de 'Terezas batistas' por todos os cantos do Brasil ainda agora. O que justifica a pertinência da literatura, particularmente esta, no estudo dos princípios do direito brasileiro correspondentes ao problema da violência de gênero. Este cordel permite que se percorra da condição antropológica até a condição legal dos eventos contados. À luz de preceitos jurídicos válidos em nosso país o romance de 1972 é passível de um reconhecimento de afronta a direitos fundamentais reconhecidos na recente legislação protetiva das mulheres, crianças e adolescentes. Isto porque remete aos usos e costumes perpetuados e em cujo objetivo pedagógico da lei está a dissolução da violência persistentemente enraíza na justificativa cultural.

\section{Discriminação positiva e segurança jurídica: a condição de Tereza, de Maria, de Penha...}

Fundamentada na discriminação protetiva, ou discriminação positiva, a Lei 11. 340/2006, reproduz os preceitos constitucionais de defesa dos direitos fundamentais do indivíduo ${ }^{14}$, nomeando as mulheres, tanto quanto faz o estatuto da criança e do adolescente - Lei 8.069/1990, como

$14 \mathrm{O}$ pressuposto da lei é assegurar à mulher os "direitos à vida, à segurança, à saúde, à alimentação, à educação, à cultura, à moradia, ao acesso à justiça, ao esporte, ao lazer, ao trabalho, à cidadania, à liberdade, à dignidade, ao respeito e à convivência familiar e comunitária", seguindo os fundamentos do artigo $5^{\circ}$ da carta constitucional brasileira. 
estatutos de direitos humanos. A finalidade da lei popularizada como Lei Maria da Penha é promover a entrada do Estado nas relações particulares das mulheres, nomeadamente as suas relações domésticas e familiares, como garantia de proteção aos direitos fundamentais da pessoa. Nesse universo em que a mulher se constitui como pessoa, muitas vezes sendo também escrava, vítima ou algoz, o ambiente da vida privada é reconhecido pela hegemonia masculina, pelo poder determinado historicamente pela violência requerendo a intervenção de uma força ainda mais poderosa.

Jorge Amado privilegia na completude de sua obra o cotidiano do povo, caracterizado por peculiaridades culturais. A vida de Tereza, como a de muitas outras mulheres brasileiras, é marcada por muita violência, não como natureza e destino, mas pela ausência de proteção tanto da família quanto do Estado. O percurso por ela trilhado decerto tem o ímpeto da sobrevivência, e neste a contra hegemonia de "uma mulher boa de briga". Tereza ficou órfã muito cedo e viveu sua curta infância com os tios. Foi uma criança livre para correr e subir em árvores, mas instruída para lidar com as brutalidades do mundo assimilando um juízo de que um bom guerreiro não chora, como uma persistente na recusa em aprender a ter medo. Dimensão de um ambiente violento que tornaria a menina valente, mas subordinada a aceitação das condições impostas pelo mundo de prevalência da vontade masculina. Esse universo em que Tereza desenvolve sua personalidade é 
próspero para a análise da responsabilidade moral e material ${ }^{15}$ da família em relação à criança e adolescente.

Responsabilidade como um princípio de direito que é primordial para proteger a criança da violência dos adultos, para garantir que seja preparada para enfrentar o mundo com segurança, autoestima e competência. Tereza foi alfabetizada, mas sua formação moral foi transpassada pela ética individualista justificada na defesa do status quo (da tia, do tio, do coronel, do doutor, do marinheiro Janú), a resistência à qualquer tipo de mudança da tradição hierárquica teria que ser levada a cabo com idêntica reação, isto é com igual implemento de violência. Por isso torna-se estratégico uma naturalização do jogo subconsciente (exemplo disso é o movimento do 'balaio fechado') como artifício da vida política, permeada também pela irascibilidade. Sua postura frente aos desafios da vida social não deixaria de lado igual violência. Não à toa ela ganhou fama de "boa de briga", mas também de 'favo de mel', 'destemida', 'omolu', 'bexiga negra' e 'cansada de guerra', pois se a violência é o lastro de sua força, o reconhecimento de que

15 A responsabilidade civil tem raízes no direito penal, pelo que a culpa e o dolo agem subjetivamente e a sucumbência de regras estabelecidas pela moral é o que lhe dá sentido e juridicidade. Quando o indivíduo viola e ofende as convenções morais e causa dano a terceiro é imputado a reparação penal ou civil. Nos casos em que o ofendido tenha sido criança ou adolescente o Estado toma a sua defesa através do Ministério Público, considerando que a ofensa à criança é ofensa a toda à sociedade e as demais gerações, incidindo mesmo numa afronta aos direitos humanos. 
a vida é dura e difícil leva-a a perceber o valor da solidariedade, da bondade e de toda sensibilidade feminina.

Conquanto o princípio da prioridade absoluta figure como norma fundamental na atual constituição federal, a criança e o adolescente devem estar, obrigatoriamente, entre as prioridades das autoridades públicas e da família. O fato de ter sido vendida ao Coronel Justiniano, por uma quantia irrisória e um bracelete barato faz-nos ver o menosprezo pela integridade física como também reafirma a responsabilidade da família. Esse abandono à responsabilidade que é ampliado na medida em que o seu tio se mostra contrário à venda, não por um gesto altruísta, mas porque queria ser ele o consumador da sua virgindade. Limite para o cumprimento da responsabilidade da tia ao perceber as intenções libidinosas do marido e que fica entre escolher a manutenção de seu casamento e 'desfazer-se da menina'.

Jorge Amado por via indireta permite-nos ver uma realidade corriqueira, que permite refletir sobre a importância da intervenção estatal como elemento regulador dos interesses da menina Tereza frente aos interesses de seus familiares e da sociedade que a "acolhia".

Tanta omissão cumula na sua completa falta de alternativa e numa condição humana promovida pela perda da infância, da inocência e de caminhos civilizados, já que se não fosse o coronel a violentá-la qualquer outro a isto se prestaria. Mostra com isto que a família é o primordial espaço de desenvolvimento do adulto que produz a sociedade. Tereza 
encontrou como possibilidade de saída o meretrício para não ser escrava sexual do coronel, mas socialmente escravizou-se ainda mais na sua condição desprezível. Amado (2010) traz à tona a problemática da desestruturação familiar, das consequências do baixo poder aquisitivo das famílias, da proximidade com agentes da violência na comunidade e das estratégias de manipulação de que se utilizam. Como também da falta de perspectiva para o futuro como condutores de um ciclo prejudicial e que de fato precisa da corresponsabilidade entre o Estado e a família. Uma direção em que como caso concreto mobilizaria uma revisão da importância histórica do surgimento do estatuto da criança e adolescente brasileiro e da sua complementação pela Lei Maria da Penha.

Bem verdade que apesar da existência dessas leis não seja estranho similaridades com situações trazidas pela comunicação social, com a diferença de que cada vez menos se naturaliza essa destinação, pois tem sido elaborado maior discernimento em torno da responsabilidade da família e do estado para com os jovens, evocando inclusive a crítica à postura familiar e à falta de providências públicas. Tanto assim, o Código Penal brasileiro estabeleceu, em seus artigos 136, 244, 246 e 247, os crimes de maus-tratos, abandono material, intelectual e moral, com penas de detenção e multa, aos violadores dos direitos fundamentais de crianças e adolescentes. O artigo 249 do ECA é pertinaz à condição de responsabilidade de quem tendo obrigações familiais, que não é apenas dos pais, e na sua ausência os sucedem no poder familiar de 
cuidar, educar e proteger. A ausência de providências nessa direção constitui infração administrativa e tem como sanção o pagamento de multa. Neste caso considera-se a corresponsabilidade e não apenas a condição paterna/materna, e nisto a narrativa de Amado remete à atenção sobre a responsabilidade dos tios de Tereza Batista.

\section{Isonomia de gênero e discriminação positiva}

O domínio do coronelismo e do paternalismo no nordeste é trazido por Amado em questões que na atualidade constituem a pauta jurídica e legal não apenas em nosso país, mas no mundo todo. A presença da violência familiar na memória brasileira é clara, por isso não se pode falar em isonomia de gênero descolada de uma discriminação positiva. A lei Maria da Penha tem se caracterizado pela virtude pedagógica nas ações afirmativas muito mais do que na punição severa aos agressores. $\mathrm{Na}$ essência, quer viabilizar à mulher o exercício dos direitos fundamentais, a saber: vida, liberdade, igualdade, segurança, propriedade, enfim, a dignidade humana. A lei estabelece, portanto, dois critérios para determinar a sua aplicação: primeiro, a mulher como sujeito de direito; o segundo, a violência familiar e o abuso afetivo. A reação dos setores conservadores, tão vivamente descritos por Amado, compõe a reação à constitucionalidade da lei sugerindo afronta a isonomia legal e não assimilando o caráter emancipatório da lei enquanto ferramenta política. A Lei Maria da Penha pretende garantir direitos fundamentais às 
mulheres mediante uma ação afirmativa das mudanças históricas. O ECA, igualmente reafirma a prerrogativa das nossas crianças serem os cidadãos da sociedade futura.

À personagem fora isso o que faltou a vida toda e disso se ressentiria por toda a vida. "Sempre em busca de afeto verdadeiro, Tereza necessitava de calor humano". Segurança que como princípio de justiça está diretamente associado à dignidade humana ${ }^{16}$ visando proteger o ser humano contra tudo que lhe possa levar ao menosprezo, à subserviência, à sucumbência de sua personalidade moral e espiritual. A carência afetiva fazia com que visse em Janú não apenas "o ar de família, quem sabe a segurança, a alegria, a bondade do doutor, mas a inteireza de homem". Qualidades que são representadas na imagem de "um homem alto, forte, corado, honesto e valente", e que se consolidam como virtude na medida em que são qualidades acompanhadas de compaixão, solidariedade, afetuosidade, virilidade, etc. O imaginário feminino é cimentado nessas expectativas em relação à figura masculina, constituindo mesmo as representações em torno do que buscar neles para completar-se e reproduzir-se. Tereza preferiu o aborto a dar ao seu filho essa luz do seu mundo.

Mesmo assim, a realidade não escapa dos desvios

16 SARLET, Ingo Wolfgang. Dignidade da pessoa humana e direitos fundamentais na Constituição Federal de 1988. São Paulo: Livraria do Advogado, 2002. A dignidade relaciona-se tanto com a liberdade e valores do espírito como com as condições materiais de subsistência. Para mencionar um exemplo recente lembrar do caso Yoki. 
dessas expectativas e a ficção revela-os sem disfarces. $\mathrm{Na}$ abstração da lei aspectos velados da violência doméstica não foram despercebidos, concorrendo ainda mais para reasseverar o lugar das subjetivações e existencialidades no direito, e no projeto legal. Tanto assim que o legislador levou em consideração que para compreender a violência das relações íntimas não basta ater-se apenas ao seu aspecto social, patrimonial, mas também ao jogo de poder e à compensação de forças, tornando-o exclusivo evento para configurar nessa lei a violência psicológica. $\mathrm{O}$ artigo $7^{\circ}$ inciso II formula uma concepção da violência psicológica, entendida como qualquer conduta que seja capaz de causar dano emocional e diminuição da autoestima, prejudicando, perturbando ou impedindo o pleno desenvolvimento e nisto inclui aspectos degradantes de variados matizes, pelo controle das ações, comportamentos, crenças e decisões, mediante ameaça, constrangimento, humilhação, manipulação, isolamento, vigilância constante, perseguição contumaz, insulto, chantagem, ridicularização, exploração e limitação do direito de ir e vir ou qualquer outro meio que lhe cause prejuízo à saúde psicológica e à autodeterminação.

A questão da violência sexual ocorrida nos moldes da violência doméstica também é trazida à tona segundo o clássico dever de favor sexual. Jorge Amado exorbita em situações desse tipo de violência, tanto pela ambiência de prostíbulo onde a personagem vivencia parte de suas cruéis experiências, como também por transitar no universo masculino e desfiar todas as concepções de mundo que generalizam o 
homem como opositor natural da mulher. Todavia, ainda quando diz sobre a bravura com que a personagem revida, também descreve um tipo de violência muito peculiar às mulheres, e que é a vingança.

Se a prostituição e o adultério sucumbiram às modernidades legais, o prochenetismo tal como está esboçado nesse cordel resiste ao tempo e aos estratos sociais. Bem verdade que reelaborado e até celebrizado, a conduta exploratória e de dominação do homem sobre a mulher se mantém como perversão afetiva ou sexual, e como tal é a tônica de toda violência. Quando o autor nos apresenta uma distinção sócio econômica entre os prostíbulos, nos mais simples eram aceitos qualquer cliente, e nos mais sofisticados os clientes eram ricos e em sua maioria coronéis, estes com mulheres fixas, fornece um quadro semelhante ao fornecido pela mídia nacional ${ }^{17}$. Violência e revide, Relações íntimas escravizadoras, dominação econômica e exploração sexual, ambiente familiar desestruturado, são largamente retirados ora da ficção para a realidade, ora imprimem na ficção a cruel realidade.

Curiosamente o contexto que inspirou Amado ainda mantém traços fortes na realidade de hoje, quarenta anos depois porque ele mostra uma sociedade que está viva e tem realização nos seres humanos com todos os seus disparates. Apesar dos avanços legais e da disseminação das informações sobre os direitos por organismos estatais ou não estatais, a

17 Para mencionar um exemplo recente lembrar do caso Yoki. 
efetividade da obrigação do estado ainda é desoladora quando sabemos que situações como a de Tereza Batista permanecem fora da ação do estado. Não se pode, todavia, dizer que há ineficácia da lei, mas falar-se da disseminação de sentidos que a lei é capaz de produzir, como um âmbito de cidadania, sabendose que os resultados demandam tempo. A lei, como discurso transformador é digerido pela acidez da crítica, e se mantém somente quando encontra consonância com a estatura histórica da sociedade, quando acompanha o seu grau de maturidade política nas medidas que impõe, e em cujo fundamento está o próprio anseio da sociedade.

Mesmo que se considere superado o coronelismo em sua forma clássica, e que tenha sido retirado do elenco legal a prostituição, consequência da liberação sexual e autodeterminação da mulher sobre o corpo, mesmo quando tenha sido abolido o pátrio poder como figura jurídica, por ser eminente derivativo da sociedade machista em que a autoridade sobre os filhos era concernente ao pai e estabelecida a abrangência da responsabilidade familiar sobre os cuidados e educação das crianças, ainda assim a comunicação social regularmente dá nota de casos de abusos familiares, da exploração sexual, da mantença de prostíbulos. Problema de efetividade dos direitos que derivam de fortes emblemas culturais que dificultam o acesso à justiça, primeiro pela sofisticação do processo judicial, depois pela complexidade com que se elaboram os fenômenos sociais envolvendo tradicionais relações de poder. Mesmo assim, o embate entre a solidez cultural e as transformações culturais 
convoca esforços e instrumentos e o direito neste caso se lhes afigura muito bem como intermediário.

\section{Conclusão}

Os estudos culturais dirigem as atenções para a valorização da subjetividade na produção da ideia, da consciência e da realidade e como tendência chega ao universo jurídico considerando que o direito não se reduz à linguagem, mas como é por ela que se manifesta promove com rapidez e versatilidade a disseminação de sentidos para o valor justiça. A importância das micronarrativas como fundamentos culturais presentes no direito entra na correnteza desse retorno à linguagem, especialmente pela literatura evidenciando a profusão de mundos e de pontos de vista sobre a realidade que interfere diretamente na forma como lidamos com o direito, com o tempo, com a sociedade, e conosco próprios.

Jorge Amado denunciou poeticamente uma realidade dolorosa, cruel e persistente. Tereza Batista é a personagem que carregou em suas costas as experiências de meninas que se tornam mulheres condicionadas a um futuro de escolhas limitadas. Tereza pode representar o grito desesperado por respeito, segurança, liberdade, que em toda a sociedade ecoa. Como escritor cujas obras correm o mundo a leitura de Amado tem difundido um quadro sociocultural brasileiro dotado de sincera veracidade, apresentando o cotidiano que muitas vezes é subdimensionado e subestimado em suas consequências, e aproximando organismos políticos da socie- 
dade organizada mundial de uma realidade que mesmo tendo sido desenhada de modo estereotipado para atender a uma semântica da literatura ficcional, em que a mulher baiana é muito sensualizada, a menina pobre e bonita está predisposta à sujeição do próprio corpo para vencer na vida, as relações conjugais são pautadas num jogo insidioso de interesses e disfarces, mesmo assim sua obra possui e reflete a validade do fenômeno antropológico na formulação de um direito em abertura. Direito que se realiza não apenas pela aristocracia jurídica e política, mas pela sociedade organizada capaz de auscultar a coletividade e deliberar prevenções e resoluções.

O romance Tereza Batista Cansada de Guerra perfila a mulher forte e inteligente fruto de uma vida de tiranias físicas e psicológicas de uma sociedade machista, limitadora, patriarcal, injusta, desigual e muito violenta. Mas também elabora pitorescamente um libelo da realidade concreta de muitas brasileiras, fomentando o desafio para o estado de direito efetivar a segurança jurídica e a promessa de justiça. Amado fez Tereza perder o medo de apanhar, de sentir fome, de ser sozinha e querer enfrentar a sociedade, dotou-lhe de candura e de braveza para enfrentar a peste, a prisão, a autoridade, como sobrevivente que não perdeu a capacidade de amar a justiça. $\mathrm{O}$ direito, como discurso e como prática, está autorizado a fazer como Amado, uma transformação na realidade concreta. 


\section{Referências}

AMADO, Jorge. Tereza Batista Cansada de Guerra. [E-book digitalizado por Argo3nauta]. Baixado em 25 de junho de 2010.

BRASIL. Lei 11. 340, de 07 de agosto de 2006. Cria mecanismos para coibir e prevenir a violência doméstica e familiar contra a mulher, nos termos do $\ 8^{\circ}$ do art. 226 da Constituição Federal, da Convenção sobre a Eliminação de Todas as Formas de Violência contra a Mulher, da Convenção Interamericana para Prevenir, Punir e Erradicar a Violência contra a Mulher e de outros tratados internacionais ratificados pela República Federativa do Brasil; dispõe sobre a criação dos Juizados de Violência Doméstica e Familiar contra a Mulher; e estabelece medidas de assistência e proteção às mulheres em situação de violência doméstica e familiar.

BRASIL. Lei 8.069, de 13 de julho de1990. Dispõe sobre o estatuto da criança e adolescente e dá outras providências.

BRASIL. Constituição da República Federativa do Brasil. Promulgada em 05 de outubro de 1988.

CASTANHEIRA NEVES, António. O direito como alternativa humana. Digesta I. Coimbra: Coimbra, 1995.

DWORKIN, Ronald. O Império do Direito. São Paulo: Martins Fontes, 1999. 
GADAMER, Hans-Georg. Verdade e método I: traços fundamentais de uma hermenêutica filosófica. Petrópolis: Vozes, 2004.

HABERMAS Jurgen. A inclusão do outro. 2.ed. São Paulo: Edições Loyola, 2004.

NUSSBAUM, Marta. Poetic justice: the literary imagination and public life. Boston: Boston Press, 1995.

OST. François. Contar a Lei. As Fontes do Imaginário Jurídico. São Leopoldo: Unisinos, 2004. Página 386

Revista Veja. Fim do conto de fadas. Editora Abril: Edição 2273, 13 de junho de 2012.

RODRIGUES, Maria da Conceição Carapinha. Discurso judiciário, comunicação e confiança. In $\mathbf{O}$ discurso judiciário, a comunicação e a justiça. V Encontro anual do conselho superior da magistratura. Coimbra: Editora Coimbra, 2008.

SANTOS, Boaventura de Sousa. A crítica da razão indolente: contra o desperdício da experiência. 5. ed. São Paulo: Cortez, 2005.

SARAMAGO, José. Ensaio sobre a cegueira. São Paulo: Companhia das Letras, 1995. 
SARLET, Ingo Wolfgang. Dignidade da pessoa humana e direitos fundamentais na Constituição Federal de 1988. Sâo Paulo: Livraria do Advogado, 2002.

Walter Benjamin. O narrador. In: Textos escolhidos. São Paulo: Câmara Brasileira do livro, 1983.

WHITE, James Boyd. The Legal Imagination: studies in the nature of legal thought and expression. Boston : Little, Brown and company, 1973.

(Endnotes) 


\title{
Beecher Stowe e Jorge Amado: Uma Visão Jusliterária da Injustiça Social
}

\author{
Ediliane Lopes Leite de Figueiredo
}

\section{Resumo}

Este artigo apresenta um análise comparativa jusliterária da temática "segregação social” nas obras Uncle Tom's Cabin (1852) - a tradução portuguesa A Cabana do Pai Tomás é usada como referência - da autora americana Harriet Beecher Stowe e Capitães da Areia (1937), do escritor brasileiro Jorge Amado. A escolha das obras justifica-se pelo fato dessas narrativas, embora escritas em períodos, sociedades, culturas e línguas diferentes, aproximarem-se ao retratarem a segregação social, tema que suscita uma investigação jusliterária por abordar questões referentes à opressão, à marginalidade, ao preconceito, fatores desencadeadores da injustiça social e que remetem direita ou indiretamente para aspectos de ordem jurídica, por isso, desafiadores para um estudo comparativo dessa natureza. A análise revela a segregação social, visível pela divisão de raças e de classes nas sociedades americana e brasileira. Como aporte teórico para esta discussão, lançaremos mão da teoria da Literatura Comparada, aliada à teoria dos estudos Direito e literatura. Dentre as perspectivas de abordagem dos estudos jusliterários, destacamos o direito na literatura. Esta perspectiva abrange pesquisas sobre a representação do tratamento que o Direito e o Estado dispensam 
aos grupos socialmente excluídos. A literatura apresenta-se como uma narrativa alternativa para problematizar o direito e caracteriza-se como meio discursivo alternativo para dar visibilidade às minorias desfavorecidas.

Palavras Chave: Literatura. Direito. Beecher Stowe. Jorge Amado. Injustiça social.

"Nada, mais do que a literatura, pode nos dar uma ideia exata das verdadeiras condições de liberdade em um determinado tempo e em um determinado ambiente; lá onde a letra nua da lei é documento manco e incerto".

(F. Ruffini)

A Literatura Comparada se situa na área particularmente sensível da "fronteira" entre nações, línguas, discursos, práticas artísticas, problemas e conformações culturais e surge como espaço reflexivo privilegiado para a tomada de consciência do caráter histórico, teórico e cultural do fenômeno literário, quer insistindo em aproximações caracterizadas por fenômenos transtemporais e supranacionais, quer acentuando uma dimensão especificamente cultural. No dizer de Susan Bassnett (1993, p.1), "Most people do not start with comparative literature, they end up with it in some way or other [...]." "A maioria 
das pessoas não começam com literatura comparada, mas terminam com ela de uma maneira ou de outra [...]".

Machado e Pageaux (2001, p.134) afirmam que o conhecimento da Literatura Comparada leva à concepção do fenômeno literário como um fenômeno cultural. O texto literário é uma forma especial de comunicação e, consequentemente, de simbolização do mundo. Ainda segundo esses teóricos, literariedade e contexto cultural, mesmo social, não podem ser dissociados, visto que, pela própria existência do público leitor, das relações entre produção literária e realidades sociais, o fenômeno literário é também um processo de socialização.

Para explorar as relações textuais no estudo comparativo é necessário, segundo Guyard (1956, p.55) não apenas mergulhar na pura e simples comparação; é interessante ressaltar as diferenças individuais ou nacionais no tratamento de uma situação. Ressaltamos, também, Buescu (2001, p.93), quando declara que a Literatura Comparada lida com o "domínio cognitivo de cruzamento interdiscursivo, interdisciplinar e intersemiótico" para justificar a comparação pela via jusliterária das obras A Cabana do Pai Tomás da escritora americana Harriet Beecher Stowe e Capitães da Areia do escritor brasileiro Jorge Amado.

Dentre as várias perspectivas que o estudo comparativo oferece, evidenciamos o tema para destacarmos alguns aspectos nas obras. Em confluência com Carvalhal (2003, p.168-169), quando declara que a "identificação em textos 
distanciados no tempo e no espaço de uma mesma temática, de idênticos recursos de representação, de uma mesma tábua de valores (...)" ajuda "a compor a comunidade literária" constatamos que o tema, não só uniu as obras, tornando-as parte da mesma comunidade literária, mas também conduziu a investigação da estrutura da narração.

Nessa esteira, direito e literatura, como criações eminentemente humanas, constroem por meio da linguagem uma determinada visão da realidade e refletem, em maior ou menor escala, as instabilidades e idiossincrasias de seus sujeitos. Gaakeer (2010, p.16-17), assegura que muito embora a função do direito possa ser a de impor a ordem, sendo esta um mero privilégio para a literatura, ambos se assemelham no objeto de descobrir e retratar o homem, bem como no de dar forma e significado aos julgamentos e atribulações que lhe surgem ao longo da vida. Por esse diapasão, é possível uma interseção entre duas obras literárias distantes temporal e culturalmente, mas eivadas de reflexões sobre direitos e injustiças sociais. O direito e a literatura operam no domínio mágico e sempre transcendental da palavra e encontram-se intimamente relacionados ao texto, ao discurso, à narração, aos interditos, às lacunas, aos espaçamentos sublimados entre os significados e o inconsciente; enfim, à comunicação, através da linguagem. É através da linguagem - construção exclusivamente humana - que o homem se relaciona com o mundo exterior, com os outros, até consigo mesmo e é através dela que o homem pensa o mundo. Estabelecendo a relação entre a literatura e direito 
dentro de campo de Literatura Comparada consideramos a questão temática da segregação social como o primeiro aspecto semelhante que permeia as duas obras. $\mathrm{Na}$ obra abolicionista da literatura americana, A Cabana do Pai Tomás, a segregação é representada pela divisão de raças. Stowe imbuída de um propósito de repúdio e de indignação ao regime escravagista denuncia a iniquidade da escravatura naquele país. A obra apresenta o conflito vivido entre os escravos norte-americanos e os ricos donos dos escravos que são proprietários de terras do sul dos Estados Unidos, mostrando quão infame era a escravidão. A secção social, desencadeada pelo racismo é a tônica do romance, escrito como contundente manifesto ao Fugitive Slave Act (Lei do Escravo Fugitivo). Os indícios de que a obra foi escrita como uma resposta abolicionista aparecem durante o transcorrer da narrativa. O romance repudia a lei, o direito e, consequentemente, a instituição que o protege, o Estado.

Ouvi falar que uma lei nos proibindo de dar de comer e de beber aos escravos que vagueiam pelos campos foi votada, no entanto não acreditei que uma assembléia seguidora dos preceitos cristãos pudesse aprová-la. - A tal lei foi aprovada proibindo os habitantes desse Estado de dar auxílio aos escravos que fogem de Kentucky. As campanhas dos abolicionistas foram tantas, que os proprietários 
daquele Estado vivem em sobreaviso constante. E para acalmá-los e lhes dar algumas garantias, o Senado de Ohio aprovou essa lei.

(STOWE, 2004, p. 69)

A Cabana do Pai Tomás, surge na segunda metade do século XIX (1852), período pré-Guerra Civil Americana, como uma resposta abolicionista à disposição legislativa de 1850 (Act Slave Fugitive) que, entre outras proibições, determinava que os escravos que tinham escapado dos Estados do Norte deveriam ser devolvidos ao cativeiro; que era considerado ato criminoso prestar assistência a escravo fugido; que os negros americanos não tinham o direito de solicitar um julgamento com júri ou a testemunhar em seu próprio nome, mesmo que fossem legalmente livres.

A história se passa no Sul dos Estados Unidos e as personagens são usadas para acentuar como era a vida durante aquele período na cultura americana. Stowe, através da sua obra, motivou as pessoas a tomarem partido sobre a questão da escravidão. O tema é abordado sob o ponto de vista de uma cristã convicta, mas nem por isso, é suprimida a questão política e legal, bem como o papel da moralidade na sociedade da época.

Capitães da Areia, por sua vez, surge na primeira metade do século XX (1937), período conturbado na história política brasileira, às vésperas do surgimento do Estado Novo 
- instauração da Ditadura Vargas. A história se passa no Nordeste brasileiro e as personagens são usadas para representar a camada social infanto-juvenil, órfã, pobre e marginalizada, segregada pela sociedade, por um sistema capitalista opressor e excluída por uma legislação que atendia aos anseios de uma classe aristocrática dominante, o Código de Menores de 1927, mais conhecido como o Código Mello Matos. Este diploma legal adotava a doutrina da Situação Irregular, pressuposto que legitimava a intervenção estatal sobre menores que estivessem em qualquer situação das circunstâncias que a lei considerasse irregular. Em âmbito jurídico, a expressão “irregular” significa patologias sociais, previstas na ordem jurídica, definidas em oposição à normalidade. As hipóteses legais definidas como tal revelavam claramente o público alvo: a infância e adolescência pobres e marginalizadas (BRASIL, 1982, p.83).

$\mathrm{Na}$ obra amadiana, o tema da infância e da adolescência marginalizada é abordado sob o ponto de vista de um escritor engajado, que busca extravasar seus ideais sociais e políticos, através das posições que seus personagens ocupam no universo sociocultural. As façanhas cotidianas nada sociáveis das personagens para sobreviver em uma sociedade que os repelia, transforma-os em "meninos-heróis" e a saga de cada um deles transforma-se numa luta em favor da dignidade humana.

A Cabana do Pai Tomás simboliza a cultura e a história de um tempo mais distante na sociedade americana. Esta obra, considerada grande clássico da literatura daquele país, 
motivou as pessoas a tomarem parte em uma questão sociopolítica de grande complexidade; Capitães da Areia, por sua vez, simboliza a sociedade, a cultura e a história de um tempo mais próximo na sociedade brasileira. É um grande clássico da nossa literatura que traz à tona reflexões sobre as estruturas sociais, o incentivo à luta e à resistência ao poder que subjuga, marginaliza e humilha.

As palavras do crítico comparatista Remak (1961, p.3), “[... o estudo da literatura além dos confins de um país particular, é o estudo das relações entre a literatura, de um lado, e das outras áreas de conhecimento e da crença $[. .$.$] ",$ faz-nos ver como dois escritores de culturas e sociedades diferentes aproximam-se, ao demonstrarem preocupação com o marginalizado e usarem suas obras como meio para reivindicar direito para defendê-lo. É interessante ver como a "comparação de uma literatura com uma outra. É a comparação da literatura com outras esferas da expressão humana.”

Observamos, ao longo do percurso de produção, que os dois escritores reunidos neste trabalho, apesar da distância temporal e cultural que os separa, aproximam-se na forma como combinam literatura e direito e também na maneira como conceberam as sociedades em que viveram. Tanto Stowe quanto Amado permitem, em suas obras, uma travessia entre a literatura e o direito que possibilita uma análise comparativa em que aspectos semelhantes e divergentes podem ser ressaltados.

A literatura vai além da posição geográfica, temporal 
e histórica e como representação simbólica dos conflitos, dos anseios e das conquistas humanas, assume uma função social. Os aspectos histórico-legais relacionados nas obras mostram que os autores literalizaram questões de ordem social e legal de épocas e de culturas diferentes e, ao mesmo tempo, desenharam literariamente o assombro da injustiça social, traço inegavelmente comum entre as obras.

Capitães da Areia, obra considerada realista/socialista da literatura brasileira, também trata da segregação social, no entanto o tema é retratado sob o prisma da divisão de classes. Amado retira dos bastidores sociais a infância pobre, abandonada e delinquente para revelar o conflito entre pobres e ricos, fracos e fortes, órfãos marginais e sociedade oprimida e opressora. A obra apresenta o drama da infância ignorada e o débito de uma sociedade individualista e preconceituosa e de um Estado negligente em leis e em ações para solucionar problemas sociais, considerados primitivos, tais como a fome e a miséria, fatores desencadeantes da delinquência infanto-juvenil.

Logo depois transferiam para o trapiche o depósito dos objetos que o trabalho do dia thes proporcionava. Estranhas coisas entraram para o trapiche. Não mais estranhas, porém, que aqueles meninos, moleques de todas as cores e idades as mais variadas, desde os 9 aos 16 anos, que 
à noite se estendiam pelo assoalho e por debaixo da ponte e dormiam indiferentes ao vento que circundava o casarão uivando, indiferentes à chuva que muitas vezes os lavava [...]

(AMADO, 2008, p.28)

Em consonância com Brunel; Pichois e Rousseau (1995, p.110) quando afirmam que "numa obra, um tema não está jamais isolado; interfere em outros, e seria mais justo falar de complexos temáticos," observamos que a unidade temática análoga nas duas obras se põe à abertura de outros eixos que as irrigam: o preconceito, a marginalidade, a opressão complexos temáticos que subsidiam o tema central nas narrativas em estudo e constituem outro aspecto semelhante nas narrativas.

Em ambas as obras, esses elos temáticos não se situam no terreno de uma linguagem abstrata, subjetiva. As personagens que representam a esfera social dominante invocam as personagens que representam as camadas sociais minoritárias e excluídas, com arbítrio, ignorância e menosprezo. A repugnância e o desprezo do poderio estatal e social para com os espoliados e desvalidos se evidenciam através da linguagem envolta de endereçamentos pejorativos e de uma nítida aspereza na desqualificação.

$\mathrm{Na}$ obra de Stowe, as personagens negras são cativas das armadilhas da invisibilidade ou da visibilidade calcada 
em estereótipos. Não raro, durante o percurso narrativo, são observadas formas depreciativas de tratar o negro: "A prima entende que domar os negros sem muita severidade é impossível, pois são maus, preguiçosos e velhacos! [...] - No dia do juízo, que horríveis contas terão de prestar essas criaturas malditas por sua preguiça inigualável?" (STOWE, 2004, p.147, grifo nosso).

Assim como na Cabana do Pai Tomás, em Capitães da Areia também são usados termos e expressões de menosprezo para tratar as crianças e adolescentes pobres e desamparadas, que também são "invisíveis", quando é conveniente para a corporativa sociedade preconceituosa e para o poder público negligente. A marginalidade, o preconceito e a opressão se concretizam nos discursos das autoridades estatais, do representante do clero e dos segmentos socialmente privilegiados. Os espoliados na obra amadiana, assim como na obra de Stowe, são rechaçados e estereotipados: "Esse bando que vive da rapina se compõe, pelo que se sabe, de um número superior a cem crianças... [...] - Isso não são crianças, são ladrões. velhacos, ladrões. Isso não são crianças.” (AMADO, 2008, p.11-81, grifo nosso).

Como se pode constatar os estigmas da opressão, da marginalização e do preconceito se fazem presentes nas duas obras de forma categórica. Tanto os escravos, na obra de Stowe, quanto as crianças e adolescentes, na obra de Amado, são cativos de um sistema social opressor, amparado por um sistema legal que os excluía e os deixava à mercê de qualquer 
direito à cidadania. A Cabana de Stowe e o Trapiche de Amado representam espaços da segregação e de todos os malefícios discriminatórios que promovem a injustiça social.

Trazendo à tona a posição legal frente à injustiça social nas obras, observamos que as narrativas colocam questões éticas, morais e de ordem prática de forma problematizadora, com o propósito de ressaltar que mais importante do que dar respostas é formular questões fundamentais que possam levar a uma reflexão sobre os critérios do direito e da justiça. Na obra de Stowe, por meio da estrutura e do conteúdo da narrativa, as vozes discursivas convidam-nos a refletir sobre um ordenamento jurídico posto, estabelecido:

- Na verdade, George, espanta-me e inquieta-me o seu estado de espírito. Você pretende violar as leis do seu país? - Novamente o meu país! De fato, o senhor Wilson, possui uma pátria, porém, eu tenho alguma, por acaso, sendo filho de uma escrava? Quais são as leis para nós? Caso não as redefinirmos nem as retificarmos, não poderemos esperar nada delas, afinal servem somente dominarmos a fim de esmagar-nos.

(STOWE, 2004, p. 94).

$\mathrm{Na}$ narrativa amadiana, o discurso legal é proferido de 
forma mais subjetiva. A obra traz um recorte da situação social do menor pobre e abandonado, ambientado em Salvador, como representação desta fração etária em toda a sociedade brasileira. Embora não tenhamos na narrativa amadiana nenhuma referência linguística explícita à lei de menores, implicitamente é o Código de Menores de 1927, estatuto em vigor na época em que a obra foi escrita, o alvo da crítica legal de Amado.

O artigo $1^{\circ}$, do I capítulo, deste Diploma Legal preceitua: "O menor, de um ou outro sexo, abandonado ou delinquente, que tiver menos de 18 anos de idade, será submetido pela autoridade competente às medidas de assistência e proteção contidas neste código.” (CIESPI, s.d.). O narrador, ao se referir às crianças e aos adolescentes pobres e abandonadas, usa as mesmas expressões insertas no referido Código:

Não cabe ao juizado de menores capturar os pequenos delinquentes. Cabe velar pelo destino posterior. [...] Ainda nestes últimos meses que decorreram mandei para o reformatório de menores vários menores delinquentes e abandonados. (AMADO, 2008, p.16-17, grifo nosso)

Nas duas narrativas, em certo sentido, estamos face a não-cidadãos absolutos, mas esta condição a que os seres humanos estão alçados, dentro do contexto social em que os fatos acontecem, está em conformidade com a lei. $\mathrm{Na}$ 
Cabana do Pai Tomás, esta realidade está em consonância com a lei que divide pela cor da pele. Em observância a esta lei, que segrega pela raça, acontece a comercialização de seres humanos e, em decorrência disso, os maus-tratos, a opressão, o preconceito, a injustiça social.

Em Capitães da Areia a lei também secciona, mas pela condição etária, pela condição do abandono e da orfandade. A consequência desse sistema legal vigente, bem como do aparato social que o protege, pode ser interpretado como uma desconstrução do sentido de justiça, uma vez que opressão, marginalidade, escravidão e direito são contraditórios, excluem-se naturalmente. Em ambas as obras, os autores procuram exteriorizar, através dos narradores e das personagens, o processo de desajustes sociais, dentro de um contexto legal que desfavorece completamente as minorias retratadas (os negros, as crianças e adolescentes).

A partir da análise dos pontos que se assemelham, pela estreiteza do tema e dos complexos temáticos, surge o despertar para a percepção das diferenças que se estabelecem entre as narrativas. Em ambas as obras, os narradores são oniscientes, podem ser considerados como "agentes integrados" no percurso narrativo, quando, ou por meio da digressão ou pela "invasão" da consciência das personagens, assumem uma posição crítica diante da injustiça social, no entanto o estilo e a forma de conduzir essa crítica são bastante diferentes e esse é um dos pontos divergentes que as obras apresentam. 
$\mathrm{Na}$ obra americana, temos uma narradora que faz uso de uma estrutura gradual para esvaziar a defesa do leitor pró-escravidão. Em algumas passagens, através de uma linguagem "aparentemente inofensiva", de uma ironia disfarçada, a narradora tenta suavizar o sistema escravagista, para, em seguida, retratá-lo como um mal, sem nenhum lado benéfico. Em algumas digressões, embora a narradora deixe transparecer uma certa indignação em relação ao sistema e à lei que o protegia, esta mantém a tônica do discurso ameno, refreado por eufemismos e envolto por aura religiosa, como estratégias racionalmente elaboradas para revelar a crítica sociolegal. Ao longo da narrativa, deparamo-nos com outros posicionamentos da narradora que ratifica esta colocação:

Talvez, quando a raça negra deixar de ser desprezada e espezinhada, apresente-se nos com as revelações mais belas que se possam associar à natureza humana. Todas as qualidades que distinguem os negros frutificarão: a simplicidade, a inocência, a docilidade, o temperamento afetivo, a deferência que lhes merece a superioridade da inteligência e a facilidade com que perdoam as injúrias. Essas qualidades todas reunidas farão da raça negra uma das manifestações da vida cristã mais 
perfeitas, e é possível que Deus, que pune aqueles a quem ama, tenha imposto tantos sofrimentos à pobre África [...]

(STOWE, 2004, p.151)

Na narrativa de Stowe, o discurso abolicionista explícito, parcial e crítico, é transferido para personagens, que, pelo respaldo social, poderiam conduzir o leitor à causa abolicionista. No entanto, o grito mais agressivo em prol da liberdade e da justiça social é habilmente posto na boca daqueles que têm legitimidade para se manifestar: a minoria silenciada que sofre literalmente na pele e sente na alma o peso da opressão, da humilhação, da marginalização, decorrentes do sistema que segrega pela cor.

[...] $\mathrm{E}$ as leis lhe permitem praticar todo o tipo de desonras! Acima da honra, acima de Deus! Pense bem nisto, Sr. Wilson! Não existe uma sequer destas arbitrariedades que não sejam absolutamente permitidas por suas leis. Podem esmigalhar o coração de mãe, de esposa, de marido, de filho, e a ninguém é autorizado falar "Não"! E o senhor terá coragem de ainda afirmar que devo subjugar-me às leis de meu país? 
Não possuo pátria, assim como não tenho pai.

(STOWE, 2004, p.95)

Em sentido inverso, em Capitães da Areia, Jorge Amado incorpora o narrador que constrói a crítica sociolegal sem gradação, sem ressalvas linguísticas. Não há preocupação em sublimar a linguagem para amenizar o discurso revelador da desigualdade, da opressão e da marginalização contra os menores abandonados. Sempre que traz o discurso para si, o narrador se posiciona de forma racional para exteriorizar a condição de orfandade estatal e social da população infantojuvenil naquele contexto e naquela época, como observamos nestes trechos espalhados pela obra: "João José era o único que lia corretamente entre eles e, no entanto, só estivera na escola um ano e meio." (AMADO, 2008, p.32). "O Sem-Pernas pensa sem compreender. Lembra os dias da cadeia, a surra que lhe deram, os sonhos que nunca deixaram de persegui-lo." (AMADO, 2008, p.125). "Almiro foi primeiro dos Capitães da Areia que caiu com alastrim..." "Os meninos foram se levantando aos poucos e afastando-se receosos do lugar onde estava Almiro." (AMADO, 2008, p. 145). "Dora estava triste e pensava em voltar ao morro... Do morro sua mãe tinha saído num caixão, seu pai metido num saco... Aquelas casas bonitas não a quiseram.” (AMADO, 2008, p.172).

O narrador amadiano se mantém apático em relação à questão religiosa, não a utiliza como estratégia sensibili- 
zadora para mascarar a crítica que surge a cada capítulo de forma mais pungente. Através do uso do discurso indireto livre, invade e "usurpa", subversivamente, os pensamentos do padre José Pedro para despejar a sua indignação e transformase no porta-voz consciente e implacável em defesa da causa que abraça:

O padre José Pedro ia encostado à parede. O cônego dissera que ele não podia compreender os desígnios de Deus. Não tinha inteligência, estava falando igual a um comunista. Era aquela palavra que mais perseguia o padre... Ele estava errado, perdera aqueles dois anos de tanto trabalho. Pensara levar tantas crianças a Deus... Crianças extraviadas... Será que elas tinham culpa? [...] Os Capitães da Areia? Não eram crianças iguais às outras... Sabiam tudo, até os segredos do sexo. Eram como homens, se bem fossem crianças... Não era possível tratá-los como aos meninos que vão ao colégio dos jesuítas fazer a primeira comunhão. Aqueles têm mãe, pai, irmãs, padres confessores, e roupas e comida, têm tudo [...]

(AMADO, 2008, p.157-158) 
Percebe-se que enquanto Stowe, talvez movida por razões ideológicas, pela formação pessoal e profissão (professora e missionária), pela condição de mulher, na sociedade americana no século XIX, encarna a narradora consciente de que era necessário subliminar o discurso para relatar a escravidão, não só como um fator sociocultural e político, mas, sobretudo, como um mal que envergonhava a humanidade e que a tornava refém de um débito para com os irmãos africanos por longos anos.

Jorge Amado, por sua vez, movido por razões político-partidárias - era filiado ao Partido Comunista Brasileiro (PCB), bacharel em Direito e jornalista - incorpora o narrador que concentra todas essas funções, pois se posiciona de forma iconoclasta, irreverente e sagaz para construir a narrativa em que a situação dos menores órfãos e abandonados demanda agressivamente por justiça social como direito do indivíduo.

Os narradores, sob óticas diferentes, através de suas obras, metaforizam as condições de miséria, de opressão e de segregação humana, como símbolos de culturas, de nações e de épocas diferentes. Movidos por ideologias e manifestações sociais diferentes, cada um, ao seu modo, conseguiu construir uma representação simbólica da realidade em que viveram e do mundo social do qual fizeram parte.

Comparando as duas obras percebemos a grandeza dessas narrativas. Harriet Beecher Stowe e Jorge Amado uma mulher e um homem - de épocas, sociedades, culturas e línguas diferentes - conseguiram, através de suas criações 
literárias, filtrar um sistema legal perverso e segregador e levar o leitor para mundos tão distantes e tão próximos.

$\mathrm{Na}$ sociedade americana, em 1865, a lei pôs fim ao regime escravagista, mas não ao preconceito, à opressão, à marginalização dos negros que continuaram, por muitos anos, condenados ao confinamento social pela divisão da "linha de cor”. Nas décadas de 1950 e 1960, quase cem anos depois da promulgação da lei que aboliu a escravidão naquele país, líderes como Reverendo Martin Luther King, um dos pilares fundamentais do movimento em defesa dos direitos civis dos afro-americanos, lutava para resguardar as conquistas legais dos negros. Cinco anos antes de ser assassinado em Memphis - 04 de abril de 1968 - Martin Luther King assim se manifestava: "Eu tenho um sonho... de algum dia, qualquer negro deste país, qualquer homem de cor no mundo inteiro, ser julgado por seu valor pessoal e não pela cor de sua pele". Esta marcante personalidade americana parecia incorporar Stowe, em Uncle Tom's Cabin.

Realidade e ficção se misturam em defesa de minorias excluídas e silenciadas por tantos séculos. Embora inúmeras batalhas ainda precisem ser vencidas, as vozes da ficção e da realidade não ecoaram em vão. Mais de cento e cinquenta anos depois da publicação da obra de Stowe e quarenta anos depois do ideológico discurso de Luther King, Barack Obama, um homem de descendência negra, caminha livre pela Casa Branca e ocupa o mais alto e mais importante cargo político dos Estados Unidos, tornando-se assim o primeiro presidente 
'não branco' da longa carreira democrática daquele país, já em seu segundo mandato.

A sociedade brasileira, apesar de não mostrar uma mudança de consciência social tão significativa para equacionar o problema dos "meninos de rua", registra transformações legais importantes em prol da causa defendida por Amado, em Capitães da Areia, há mais de setenta anos. Em 1990, foi criado o Estatuto da Criança e da Adolescência (ECA), um novo Diploma Legal para proteger e salvaguardar os direitos da população infanto-juvenil. Este Certificado Legal não apresenta nenhum caráter delimitador ou excludente, (como o Código de Menores de 1927), está pautado, sobretudo, na doutrina da proteção integral e alicerçado em princípios constitucionais. Essa nova condição jurídica a que foram alçadas as crianças e os adolescentes coloca-os em posição de igualdade em relação aos adultos. Hoje, perante a lei, ambos são vistos como pessoa humana, possuindo direitos subjetivos que podem ser exigidos judicialmente.

\section{Considerações Finais}

A riqueza de ideias com que problematizam a segregação social nas obras nos fez concluir que a partir da literatura comparada é possível questionar o direito e sua função em uma sociedade e nos conduziu a reflexões e a questionamentos sobre o débito sociolegal que as sociedades americana e brasileira contraíram com essas frações populacionais, consideradas minoritárias e, por isso, excluídas e renegadas. 
Isso nos conduziu a um salto no tempo e a breves observações sobre o processo de mudanças legais e comportamentais ocorridas nas duas sociedades, após a publicação das referidas obras, em relação à causa alvo da crítica desses autores.

A análise comparativa das obras A Cabana do Pai Tomás e Capitães da Areia pela ótica jusliterária nos leva a considerar a literatura como autêntico observatório social e que através dela podemos entender os homens - princípio e fim do direito -, os interesses, os valores, as contradições, conflitos que legitimam ou reivindicam o direito. Resta-nos admirar a ousadia de Stowe e de Amado que, através de suas obras, fazem ecoar ainda hoje um melodioso canto de clemência e de ajuste social às frações sociais espoliadas, excluídas e ameaçadas, e ainda nos proporcionam a possibilidade de realizar estudos críticos dessa natureza, através dos quais são lançadas reflexões sobre valores universais como, justiça, igualdade, humanidade e alteridade, expressões tão em voga na atualidade.

\section{Referências}

AMADO, Jorge. Capitães da areia. Posfácio de Milton Hatoum. 6.ed.reimp. São Paulo: Companhia das Letras, 2008.

BASSNETT' Susan, Comparative literature: a critical introduction. Oxford: Blackwell, 1993. 
BRASIL. Código de menores. Lei nº. 6.697/79: comparações, anotações, histórico. Brasília: Senado Federal, 1982.

BRUNEL, P.; PICHOIS, CL. \& ROUSSEAU, A.M. Que é literatura

comparada? Traduçção de Célia Berretini. São Paulo: Editora Perspectiva, 1995.

BUESCU, Helena. Literatura comparada e teoria da literatura: relações e fronteiras. In: DUARTE, João Ferreira; GUSMÃO, Manuel. (Org.). Floresta Encantada: novos caminhos da literatura comparada. Lisboa: Dom Quixote, 2001.

CARVALHAL, Tânia Franco. O próprio e o alheio: ensaios da literatura comparada. São Leopoldo: Unisinos, 2003.

CIESPI. Código de Menores - Mello Mattos. Decreto n. 17.943 A - de 12 de outubro de 1927. Consolida as leis de assistência e proteção a menores. Disponível em: <http:// ciespi.org.br/media/decreto_17.943\%20A_12_out_1927. pdf>. Acesso em: 15 set. 2010.

GRAAKER, Jeanne. O Negócio da lei e da literatura: criar uma ordem imaginar um homem. In: TRABUCO, Cláudia; BUESCU, Helena; RIBEIRO, Sônia. (Coord.). Direito e literatura: mundos em diálogo. Coimbra: Almedina, 2010.

GUYARD, Marius François. A Literatura comparada. Tra- 
dução de Mary Amazonas Leite de Barros. São Paulo: Difusão Européia do Livro, 1956.

MACHADO, Álvaro Manuel; PAGEAUX, Daniel-Henri. Da literatura comparada à teoria da literatura. 2.ed. rev. ampl. Lisboa: Presença, 2001.

REMAK, Henry. Comparative Literature, its Definition and Function. In: Newton Stalknecht and Horst Frenz (eds). Comparative literature: Method and Perspective. Carbondale: Southern University Press, 1961.

SILVA, Joana Aguiar e. A prática judiciária entre Direito e Literatura. Coimbra: Almedina, 2001.

STOWE, Harriet Beecher. A cabana do Pai Tomás. Tradução de Caroline Ramos Furukawa. São Paulo: Madras Editora, 2004. 


\section{Fronteiras, Travessias e Passagens... O Entre-Iugar do Maravilhoso em "O Sumiço Da Santa" de Jorge Amado}

Patricia Gomes Germano

\section{Resumo}

"Lo maravilloso comienza a serlo de manera inequívoca cuando surge de uma inesperada alteración dela realidade (el milagro) [...]". Assim alerta Carpentier (1989) quando conceitualiza o real maravilhoso. Para o autor, no contexto literário, o maravilhoso acontece quando uma alteração da realidade, entrevista pela obra, projeta-se numa "consciência de fé", numa adesão particular daqueles que experimentam esse "desestabilizar" cosmogônico, não somente no aspecto literário, mas, sobretudo, em vivências inusitadas experimentadas por determinado grupo. Logo, cabe à literatura maravilhosa transformar-se numa espécie de "refratário" de experimentações vivificadas e não contraditórias em dada vivência. É notório no universo literário amadiano a constante presença de cosmogonias mítico-sacrais em convivência, sejam as sacralidades afro-brasileiras, com especial relevo para os rituais de matriz iorubá, seja a constante menção ao catolicismo e a seus dogmas e, principalmente, a hibridação orquestrada entre os dois códigos sacrais. Aqui o nosso olhar analisará a representação do maravilhoso, o reencenar dos mitos e das travessias, a quebra de fronteiras entre a realidade consolidada 
e o insólito sobrenatural alavancados na diegese de O sumiço da santa: uma história de feitiçaria (1988), cuja novidade, ao que parece, é por em cena as ações maravilhosas ocorridas num período quaresmal na cidade de Salvador, mescladas ao reviver mítico queto-nagô. Tais sacralidades aparecem imbricadas e compartilhadas entre personagens empenhados em naturalizar o insólito. Como esteio teórico, faremos uso dos estudos de Carpentier (1989); Chiampi (1980); Reis (2005); Prandi (2005); Capone (2004); Bastide (2000), os três últimos para solidificar as incursões na mitologia de matriz afro-iorubá.

Palavras-chave: Jorge Amado. Real maravilhoso. Sacralidade. Literatura.

\section{Para início da discussão}

Autor de várias obras e de fácil aceitação junto ao público leitor, Jorge Amado apresenta-se como um escritor que se reporta ao povo naquilo que produz, sendo agenda principal de sua temática as problemáticas do cotidiano, enriquecidas pela simplicidade artística de uma linguagem literária estruturalmente mestiça, consciente do potencial da mistura como escopo para uma literatura dinâmica, viva, uma performance quase barroca em convívio harmonioso com a singeleza de um mero contador de histórias.

No multifacetado romance, O sumiço da santa: uma história de feitiçaria (1988), escrito num intervalo de vinte anos, Jorge Amado mostra-se como um "bricoleur" capaz de 
unir várias técnicas narrativas empenhadas em arregimentar um texto problematizador da identidade religiosa. No universo maravilhoso vivificado na trama, há a inserção de uma realidade mágica, livre da hesitação leitor/personagem perante o sobrenatural que é típica da literatura maravilhosa.

"Lo maravilloso comienza a serlo de manera inequivoca cuando surge de uma inesperada alteración dela realidade (el milagro) [...]". Assim alerta Carpentier (1989) quando conceitualiza o real maravilhoso. Para o autor, no contexto literário, o maravilhoso acontece quando uma alteração da realidade, entrevista pela obra, projeta-se numa "consciência de fé", numa adesão particular daqueles que experimentam esse "desestabilizar" cosmogônico, não somente no aspecto literário, mas, sobretudo, em vivências inusitadas experimentadas por determinado grupo. Logo, cabe à literatura maravilhosa transformar-se numa espécie de "refratário" de experimentações vivificadas e não contraditórias em dada vivência.

É notório no universo literário amadiano a constante presença de cosmogonias mítico-sacrais em convivência, sejam as sacralidades afro-brasileiras, com especial relevo para os rituais de matriz iorubá, seja a constante menção ao catolicismo e a seus dogmas e, principalmente, a hibridação orquestrada entre os dois códigos sacrais.

O nosso olhar, nesse artigo analisará a construção do maravilhoso, o reencenar dos mitos e das travessias, a quebra de fronteiras entre a realidade consolidada e o insólito sobrenatural alavancados na diegese de $O$ sumiço da santa: uma 
história de feitiçaria (1988), cuja novidade, ao que parece, é por em cena as ações maravilhosas ocorridas num período quaresmal na cidade de Salvador, mescladas ao reviver mítico queto-nagô. Tais sacralidades aparecem imbricadas e compartilhadas entre personagens empenhados em naturalizar o insólito.

\section{O real maravilhoso transcultural no texto amadiano}

Comumente o trabalho de Amado é compreendido pela crítica como detentor de dois momentos principais: o primeiro concentrado numa demarcação político-filosófica dos ideais pertinentes ao Partido Comunista e a "propagandear", através do discurso literário, os fundamentos de um Estado-Nação bem enquadrado dos ditames eletivos "apropriados" a essa estrutura; o segundo, que tem Gabriela: cravo e canela como marco inicial, inaugura uma nova fase que deixa o tom panfletário, por vezes proselitista e doutrinário das obras anteriores, com ênfase na divulgação dos paradigmas marxista, para adotar uma expressão textual compromissada com um "mínimo de literatura" para um "máximo de realidade" (AMADO, 2001a) ${ }^{1}$. Assim, o autor amplia seus mecanismos estéticos graças à liberdade discursiva enfatizada quando o rigor do romance de tese é substituído por textos em que

1 Frase de abertura do romance Cacau (1933) exaustivamente usada pela crítica para condenar a "pouca" expressividade estética do autor. 
tanto a forma como o conteúdo apontam para o trânsito entre a prosa documental, naturalista e didática, e os acordes do lirismo poético, do subjetivismo e do ressurgimento de linhas temáticas antes relegadas ao esquecimento.

A crítica não entra em consenso quanto à natureza dessa mudança. Alguns a veem como radical, outros, como mera continuidade. Para Bosi (1970), são crônicas “amaneiradas" e costumes provincianos dissolvidos no pitoresco, no apimentado do regional. Para Albuquerque (1999), Jorge Amado continua preso às concepções de etnicidade, revalorizando a raça, do ponto de vista cultural e psicológico, na medida em que defende a mestiçagem como um ponto de partida para personalidades sincréticas sem se ater ao nível psicológico das personagens.

Por vieses díspares, estudiosos como Manzatto (1994) e Swarnakar (1998) entendem que não há descontinuidades ou pieguice nesse segundo momento. Manzatto salienta que "não existe ruptura entre as duas fases da literatura de Amado, entre o narrador social da primeira fase e o escritor sorridente da segunda. Mesmo porque, tanto em uma como em outra, o que transparece de sua literatura é o engajamento pela liberdade" (p.98) uma liberdade que nesse segundo momento esforça-se por desconsiderar o dualismo clássico assumido nos textos anteriores e passa a celebrar a riqueza do encontro, da hibridação, da lógica carnavalizada assumida por personagens decididos a viver no entre-lugar, na fronteira demonstrando, sobretudo, a fragilidade de toda ordem biná- 
ria. Na palavra de Swarnakar, a obra "does not appear to be a dividing line in his career." (p.171) e o Amado continua apresentando o que ela chama "social consciousness".

Para Da Matta,

Em termos literários, a originalidade desta fase de Jorge Amado é que, ao sério, ele responde com o carnavalesco; ao normativo e ao partidário ele contrapõe o pessoal, o singular e o milagroso; ao materialismo formalista e retórico, ele ataca com a informalidade e com a religiosidade; a vida definida como fórmula econômica, ele apresenta o mundo como uma complicada teia de relações pessoais que sustenta a esperança nas boas amizades e se celebra a relação pela relação

(DA MATTA, 1997, p 128)

Assim, podemos nos aproximar do romance em estudo como um dos representantes máximo dessa vertente amadiana em cujo cerne está balizada a noção dos vários hibridismos a que estão sujeitos à dinâmica das relações sociais, principalmente àquelas que tratam da demarcação entre o natural e o sobrenatural.

Nessa perspectiva, O sumiço da santa: uma história 
de feitiçaria protagoniza, num olhar primevo, ações que problematizam as hibridações próprias das fronteiras, em suas amplas possibilidades simbólicas, contexto que desnuda a precariedade da divisão, do sedentarismo e celebram a riqueza das possibilidades. Para Pesavento:

[...] as fronteiras não são apenas marcos divisórios construídos, que representam limites e que estabelecem divisões. Elas também induzem a pensar na passagem, na comunicação, no diálogo e no intercâmbio. Figurando um trânsito não apenas de lugar, mas também de situação ou época, esta dimensão da fronteira aponta para a instigante reflexão de que, pelo contato e permeabilidade, a fronteira possibilita o surgimento de algo novo, híbrido, diferente, mestiço, de um terceiro que se insinua nesta situação de passagem.

(PESAVENTO, 2001, p.8)

Nessa perspectiva, as ações cambiantes de $O$ sumiço da santa criam uma ideia do novo como ato insurgente de "tradução cultural" e articulam a criatividade inerente à fronteira, não mais geografia de separação, mas território da imprevisibilidade criativa que desorganiza velhas ordens num processo 
de contínuo devir.

A continuidade estabelecida pela fronteira entre mundos e entendimento de mundos, encontram aporte na visualização das cosmogonias excluídas e que agora são recuperadas por abordagens literárias. Para Bernd:

As primeiras tentativas de incorporar ao patrimônio letrado a visão mítica presente nas cosmogonias americanas só foram levadas a cabo pelos modernistas graças, sobretudo, ao ingente trabalho de pesquisa realizado por Mário de Andrade. Sua tentativa de abolir a distância e a hierarquização entre cultura de extração popular e cultura letrada foi realmente significativa, tendo sido determinante para que a Literatura Brasileira atingisse sua maioridade.

(BERND, 1998, p.141)

Para Rama (1982), a separação entre o lado mítico afro-ameríndio e a literatura, tida como espaço erudito, começa a ser realmente rompida com a proliferação de um novo contexto literário fronteiriço que surge no Brasil durante os anos 60. Essa proposta teve como aporte maior a reutilização das formas mítico-maravilhosas que haviam permanecido sob a égide de um isolamento excludente durante anos. 
A esse "viés" literário, que recupera as formas arcaicas de um cosmogonias obscurecidas pelo preconceito ocidental, dá-se o nome de "realismo maravilhoso"2 movimento que se consolidou num fenômeno universal, mas que conheceu enorme repercussão na América Latina, certamente porque o mundo americano conjuga o verbo interagir.

De acordo com Chiampi (1980), em 1948 Alejo Carpentier publica na Venezuela o ensaio Lo real maravilhoso, texto que mais tarde serviria de prólogo ao romance $\mathbf{E l}$ reino de este mundo. Centrado na apresentação de justificativas para as características de suas obras e para explicar ainda, o próprio entendimento do mundo latino-americano, o ensaio propõe o conceito de real maravilho, ou de realismo maravilhoso para exprimir a existência de uma suposta realidade maravilhosa, inerente à América Latina, oriunda da conjunção de uma natureza exuberante com uma cultura de natureza mestiça, em cujo locus ocorrem fatos que podem apresentar-se como insólitos, irracionais aos olhos do estrangeiro.

Conforme o autor, essa alteração da realidade deve projetar-se uma consciência de "fé", de crença no maravilhoso de modo que a visualização dele seja possível.

2 Neste estudo, não se entra em detalhes sobre a proliferação de termos que tentam dar conta da inclusão de aspectos míticos nas artes em geral. Dessa forma, elenca-se aqui apenas o conceito de realismo maravilhoso na perspectiva de Alejo Carpentier estudado por Chiampi (1980), por entender que ele melhor responde as propostas narrativas expressas no romance em análise. 
Os pressupostos de Carpentier distanciam-se da noção de fantástico propagada pelos contos de fadas e por textos de autores europeus, como os surrealistas, por exemplo. Para o autor, é preciso que a noção do maravilhoso extrapole puramente o literário, ou seja, não se apresente apenas como "artimaña literária", mas encontre referência nas situações sociais de um grupo e que se concretize em modos de explicação e conhecimento próprios de uma dada cosmogonia para, só então, se fazer presente no texto literário, inclusive interferindo na sua configuração.

De acordo com Esteves e Figueiredo (2005, p. 411), a acepção mais comum ao termo realismo maravilhoso, "referese a obras em que duas visões contrastantes de mundo, uma mágica e outra racional, apresentam-se como se não fossem contraditórias, usando para isso, elementos míticos e crenças de grupos étnico-culturais para quem tais contradições não se manifestam". Evidentemente, proporcionando ao texto, no que diz respeito ao conteúdo, um caráter fronteiriço.

Conforme exposto, a inserção de aspectos mítico-religiosos foi uma das pressuposições das narrativas transculturais estudadas por Rama (1982). Para o teórico, essa fusão constitui-se o terceiro mecanismo da transculturação que, no âmbito das cosmovisões, trabalha, justamente, os legados autóctones, as experiências mítico-religiosas relegadas ao silenciamento ou à discriminação pela cultura estrangeira, sem, para tanto, abrir mão da última, numa atitude de fusão não excludente.

Assim, o surgimento de realismo-maravilhoso e do 
ilogismo, que advêm das contestações vanguardistas, irá caminhar lado a lado, enfatizando às múltiplas associações e às relativizações das verdades absolutas tão caras ao realismo do romance social. Desse modo:

Acaba-se por reconhecer a existência de um universo disperso, de livres associações, de infinita inventividade, que relaciona ideias e coisas, com uma mobilidade e ambiguidades únicas. Um universo que, na verdade, sempre existiu, mas que permaneceu oculto pelos rígidos cânones do positivismo, e que, neste momento, se revigora através do movimento irracionalista europeu do século XX, permitindo o reaparecimento das culturas rurais latino-americanas, que agora podiam ser apreciadas sob novos prismas.

(REIS, 2005, p. 477)

A narrativa em análise traz uma representação dessa fronteira, de espaço movediço onde as tendências literárias canônicas do realismo sociológico misturam-se àquelas adquiridas das antigas representações mítico-religiosas de matriz africana, ou seja, conferindo ao texto a emblematização de realismo maravilhoso, contexto em que o "sobrenatural apre- 
senta-se de forma realista como se não contradissesse a razão" (REIS, 2005, p.412).

É por intermédio de várias passagens do texto de Amado que o leitor enverada pelo real maravilhoso de um mundo transcultural presentes no texto. Um possível ângulo para análise é observar a própria titulação da obra "O sumiço da santa: uma história de feitiçaria, romance baiano". A mistura condensada no próprio título, que comporta tanto a sacralidade católica, como os feitiços mágicos por ela condenados e a referência à localização "baiano" parecem justificar a ocorrência das feitiçarias "católicas" em um local especial, um território onde "são tantos os deuses e tamanhos os prodígios, que se perde a conta dos milagres e já não se atenta neles, comezinhos, corriqueiros" (AMADO, 1999, p.332). Por outro lado, o título inicialmente cogitado "A Guerra dos Santos", mostra-se de todo inadequado, já que a narrativa em si é uma celebração das possibilidades identitárias móveis e fluidas tantos dos seres numinosos quanto das personagens.

Assim, a perspectiva do real maravilhoso e da transculturação cosmogônica ganha espaço na voz de um narrador que enfatiza a naturalidade, a ausência da hesitação das personagens envolvidas perante um fato que contradiz a lógica natural. Não há dúvida, não há medo, inexiste a incoerência. O leitor e os habitantes desse universo mágico aceitam, de bom grado, as "maravilhas" ocorridas na espacialidade e na temporalidade da narrativa. 
No capítulo inicial, intitulado $A$ travessia ${ }^{3}$ (AMADO, 1999, p.03), mais precisamente, no subgrupo $O$ desembarque (p.10), o narrador dá continuidade ao processo de transculturação cosmogônica e ao relato real maravilhoso, quando narra a chegada da imagem de Santa Bárbara à cidade de Salvador e enfatiza a transformação mágica da imagem em orixá que, naturalmente, desce da embarcação e toma rumo desconhecido:

Antes que Mestre Manuel e Maria Clara, terminada a amarração do saveiro, fossem cuidar do transporte da imagem, a santa saiu do andor, deu um passo adiante, ajeitou as pregas do manto e se mandou. Num meneio de ancas, Santa Bárbara, a do Trovão, passou entre Mestre Manuel e Maria Clara e para eles sorriu, sorriso afetuoso cúmplice. A ebômin colocou as mãos abertas diante do peito no gesto ritual e disse: Eparrei Oyá! Ao cruzar com o padre e a freira, fez um aceno gentil, piscou o olho para o padre. Lá

3 Ao iniciar o romance com a imagem de uma travessia e de um desembarque, Jorge Amado retoma um argumento já desenvolvido em outras obras, como por exemplo, O país do carnaval (1931) e Terras do sem fim (1943). O uso de embarcações e a metáfora da viagem ainda estão presentes em grande parte de seus textos, como Gabriela, cravo e canela (1958), Tieta do Agreste (1967), A morte e a morte de Quincas Berro d’água, (2001). 
se foi Santa Bárbara, a do Trovão, subindo a Rampa do Mercado, andando para os lados do elevador Lacerda.

(AMADO, 1999, p.10-11)

Conforme exposto, para que o realismo maravilhoso não se transforme numa mera convencionalidade literária é necessário que a cosmogonia visualizada esteja presente no imaginário do grupo que é representado e, portanto, não venha a "agredir" a verossimilhança do universo retratado, porque ali é admissível esse tipo de situação.

Talvez resida nesse fato um dos motivos que justificam a preferência por Salvador, espaço consagrado à religiosidade em que o legado mítico de matriz africana convive com a racionalidade cosmopolita, conforme fica evidente no fragmento a seguir em que o narrador parafraseia os pensamentos de Dom Maximiniano sobre o lugar onde, em diáspora, reside:

Inclusive sobre essa terra da Bahia para onde o destino o conduzira para nela viver e trabalhar. Terra onde tudo se mistura e se confunde, ninguém é capaz de separar a virtude do pecado, de distinguir entre o certo e o absurdo, traçar limites entre a exatidão e o embuste, entre a realidade e o sonho. Nas terras da Bahia, santos e encantados abusam dos milagres e da feitiçaria, e 
etnólogos marxistas não se espantam ao ver imagem de altar católico virar mulata faceira na hora do entardecer.

(AMADO, 1999, p. 36)

E assim, é possível tanto para o padre como para freira e, mais do que tudo, à Maria Clara, a ebômin ${ }^{4}$, com anos de experiência, aceitar a transformação da imagem em um ser que pratica ações semelhante a dos humanos, mas que é uma divindade iorubá. É pertinente ainda, o posicionamento dos etnólogos que, mesmo a par das teorias marxistas, não duvidam dessas realidades míticas próprias do local.

Nesse aspecto, principalmente no que toca à retomada do discurso marxista, observa-se, no fragmento anterior, uma tendência autobiográfica do autor, já que ele, por muito tempo, orientou seus romances com base na citada teoria, mas não se furtou de tornar-se adepto das crenças e rituais candomblecistas. Aliás, o fluxo entre crenças e cosmovisões já havia sido abordado em Tenda dos Milagres (1969), quando o cientificismo de Pedro Archanjo não lhe exime das práxis religiosas.

Com intuito de melhor exemplificar a aceitação do maravilhoso na perspectiva de crença, de fé participativa por vivências coletivas que não excluem as cosmogonias representadas, (CARPENTIER, 1989), expõe-se, como exemplo, o

$4 \mathrm{O}$ termo Ebômin ou Ebome designa a filha-de-santo com sete anos de iniciação e que tenha se submetido às obrigações rituais de costume. É uma espécie de conselheira dos recém-iniciados. Cf. Pessoa de Castro (2001). 
fragmento a seguir cujo enfoque é, novamente, a transmutação do inanimado. Nele, a imagem de São Jorge salva Iansã, metaforizada em atraente negra, de ser estuprada pelo ladrão de obras de arte Pergentino Quarta-Série, quando esta descansava no ateliê do artista Carybé. Retirado do capítulo Giroflê, o excerto demonstra bem a mistura de perspectivas:

De pau duro, Pergentino Quarta-Série esqueceu a arca de Goa e o tesouro do oriente, abriu a braguilha da calça jeans preparando-se para agir: [...].

Não chegou a tocar sequer na dama, a sentir o calor e a blandícia da boca e do xibiu, pois no mesmo instante em que empunhou a vara, do alto da estante onde estava colocado, o São Jorge de granito, sem desmontar do cavalo branco, seguido pelo dragão de fogo, saltou sobre ele, investiu com a lança dirigida para os quibas e a estrovenga do galã das amas.

(AMADO, 1999, p. 104-106)

É assim que, no decorrer de variadas passagens, somam-se as evidências desse intercâmbio entre valores simbólicos e culturais, antes arraigados ao plano do mítico e do irreal, agora interconectados aos acontecimentos verossímeis. 
Relevante perceber que a obra se torna ainda mais atual em que pese à abordagem a respeito de furtos de obras de arte e de quadrilhas especializadas em fraudá-las. Como exemplo, o próprio bandido Pergentino Quarta-Série, perito em invadir ateliês de artistas plásticos famosos, mas que não estranha a intervenção mágico-anímica de um santo - banido da hagiografia católica - estátua-personificada.

Como outro recurso de valorização do sagrado iorubá vivificados nessa realidade mágica, o autor constrói um subgrupo intitulado: As águas de Oxalá (p.51) e, a partir de um relato mítico proferido pelas rememorações de uma filha de Oxalá tia Gildete -, a história de Iansã, Adalgisa, Manela e Dom Max; abre espaço para que o "Deus da criação" do panteão nagô possa ser descrito.

O fato de um relato mítico encontrar-se nas páginas iniciais do romance mostra a importância da divindade como criador, como se as ações presentes na mitologia servissem de parâmetro para quem dela toma conhecimento no presente:

- Contam os antigos, ouvi de minha avó, negra grunci, que Oxalá saiu um dia percorrendo as terras de seu reino e dos reinos de seus três filhos, Xangô, Oxóssi, Ogum, para saber como vivia o povo, na intenção de corrigir injustiças e castigar os maus. Para não ser reconhecido, cobriu o corpo com trapos de mendigo e partiu a perguntar. 
Não percorreu muito caminho: acusado de vadiagem, levaram-no preso e o espancaram. Por suspeito meteramno no xilindró, onde, ignorado, viveu anos inteiros, na solidão e na sujeira. Um dia, passando por acaso defronte da mísera cadeia, Oxóssi reconheceu o Pai desaparecido, dado por morto. Libertado às pressas, cercado de honrarias, antes de retornar ao palácio real foi lavado e perfumado. Cantando e dançando, as mulheres trouxeram água e bálsamo e o banharam; as mais belas aqueceram-lhe o leito, o coração e as partes.

(AMADO, 1999, p. 51-52)

Nas cosmogonias de matriz-africana, principalmente na dos povos iorubás, os mitos representam acontecimentos do passado que não obedecem a uma ordem linear, ou seja, cada mito não se liga a outros em ordem cronológica, conforme os parâmetros do pensamento ocidental, mas são utilizados, pela consulta ao Ifá, a fim de esclarecer as situações do presente.

Para Prandi (2005, p.31), "cada mito atende a uma necessidade de explicação tópica e justifica fatos e crenças que compõem a existência de quem o cultiva, [...], o mito fala do 
passado remoto que explica a vida no presente." Portanto, ele é narrado para estabelecer uma reflexão ou para "moldar" o comportamento dos filhos e filhas-de-santo ligados ao orixá mitificado.

A inserção do mito de Oxalá, narrado pela personagem Gildete, irmã de Adalgisa e fiel do candomblé, de certa forma, molda o comportamento da personagem, pois ela é apresentada como filha do orixá e como ele, encontra-se inconformada com o desconserto do mundo, em específico, com as injustiças sofridas pela sobrinha Manela, vítima da violência e da intolerância da tia Adalgisa.

Já na economia da própria narrativa, é interessante observar a semelhança entre o mito de Oxalá e a vida da personagem Manela que surge como um "reviver" mitológico, pois se Oxalá sofre o distanciamento da família, Manela sofre a perda dos pais. Se Oxalá é acusado de vagabundagem, Manela é taxada pela tia como libertina e mundana. Se Oxalá é preso e vítima de uma surra, Manela sofre os castigos corporais "pela taca do couro", além de ser confinada num convento. Por fim, se Oxalá encontra respeito e honrarias, Manela é redimida por Iansã que a salva do cativeiro.

Por esse olhar, entende-se que o realismo maravilhoso faz das cosmogonias de matriz africana e do relato mítico de Oxalá um "modelo" para a própria composição conteudística do romance. Nele uma espécie de ciclo correspondente à compreensão da religiosidade afro iorubá, para quem o futuro é o simples retorno ao passado, porque "para

\section{4}


os antigos sudaneses, nada é novidade, tudo o que acontece já teria acontecido antes. Identificar no passado mítico o acontecimento que ocorre no presente é a chave da decifração oracular”. (PRANDI, 2001, p.18).

Interessante ainda, a visualização de tempo cíclico no próprio espaço onde o mito é narrado: a festa da lavagem do Bonfim, pelas águas de Oxalá que representam o renascimento, a luta contra qualquer violência e ainda, o subtítulo: $O$ vôo da andorinha (AMADO, 1999, p. 56) onde são apresentadas as sensações de Manela em plena liberdade. "Sensação de alívio, de bem-estar, o desejo único e urgente de viver, insidiosa euforia, doce loucura: a andorinha liberta batia as asas, pronta para alçar vôo e descobrir o mundo: Manela ria à toa".

A associação da personagem Manela com um pássaro, em muito recupera os relatos míticos das Iyá mi, as mães ancestrais dos povos iorubás. Para Augras (2000, p. 18), "na simbologia iorubá, o pássaro representa o poder procriador da mãe. As penas do pássaro, como as escamas do peixe, aludem ao número infinito de descendentes, que estão, por assim dizer, implicitamente presentes no corpo materno."

Se Manela aparece como pássaro, como andorinha, uma ave conhecida pela independência da fêmea em relação ao macho, revive a essência das Iyá mi que eram livres e representadas pelo símbolo maior do feminino, das antigas mães ancestrais iorubás: as Elèyé (feiticeiras que se transformam em pássaros), identificando-se com Iyá mi Osóronga, a terrível mulher-pássaro, chefe das feiticeiras (MARTINS, 2001). 
No caso da cosmogonia católica, é interessante observar o episódio em que Santa Bárbara chega à Clausura das Arrependidas, a fim de libertar Manela, e é, imediatamente reconhecida pela irmã Eunice com quem viajara no dia anterior:

Ao dar com Santa Bárbara do lado de fora, postada no passeio, irmã Eunice sorriu, retirou o rosto do postigo, puxou o ferrolho, abriu a pequena porta embutida no portão. A santa retribuiu-lhe o sorriso:

- Boa noite, Eunice. Que a paz do Senhor seja contigo.

- A bênção, Santa Bárbara. Vosmecê por aqui? Veio passar a noite? Entre, a casa é sua.

Santa Bárbara pôs-lhe a bênção e, em seguida, estendeu-lhe o papel oficial com o carimbo, data, assinatura, os requisitos burocráticos.

(AMADO, 1999, p. 303)

A religiosa dialoga com a imagem personificada e a recebe com naturalidade, conversam animadamente e ambas dirigem-se para o quarto de Manela. Já na rua, em frente ao convento, após soltar a moça, a Santa desaparece e surge uma "negra, vestida com trapos cor de vinho, 
bonita como o quê" (p.306). Esta, "sorriu para Manela, lhe entregou o eiru feito de crina de cavalo e se desvaneceu" (AMADO, 1999, p. 306).

As personagens humanas envolvidas na cena não demonstram surpresa, espanto ou medo. Todas compreendem o que se passa e aceitam as ações do fantástico, porque convivem com tais acontecimentos mítico-sacrais que também são acionados como forma de conhecimento.

No que diz respeito à questão das fronteiras inseridas no texto, é importante observar um outro aspecto, aquele que une os antigos sedentarismos culturais, étnicos e religiosos.

Nas palavras de Bauman (2001, p. 20):

ao longo do estágio sólido da era moderna, os hábitos nômades foram mal vistos. A cidadania andava de mãos dadas com o assentamento, e a falta de "endereço fixo" e de "estado de origem" significava exclusão da comunidade obediente e protegida pelas leis, frequentemente tornando os nômades vítimas de discriminação legal, quando não, de perseguição ativa. [...]. No estágio fluido da modernidade, a maioria assentada é dominada pela elite nômade e extraterritorial.

Como metáfora dessa inerente mobilidade, como 
expressão de um espaço intersticial onde as binaridades mesclam-se, infiltram-se nas fissuras da concepção hierárquica criadas para erigir ordens e obediências, pode ser lida a narrativa amadiana.

Na situação inicial da obra, percebe-se um espaço para a metaforização e para ideia de trânsito adquirido pelos objetos, práticas, identidades e culturas na pós-modernidade. Ao utilizar o título $A$ travessia, Jorge Amado imprime ao texto a ideia de fronteira, de entre-lugar (SANTIAGO, 2000) e cria, aos olhos do leitor, a perspectiva de passagem, de trânsito, de transformação, haja vista esse percurso ocorrer no meio aquático. Desse modo, consegue representar a movência da fronteira não pelo entendimento da diferença, mas como possibilidade de novas aquisições e de amplas infiltrações.

Aos cuidados do casal de saveirista, a valiosa imagem sacra deixa Santo Amaro da Purificação a bordo do saveiro "Viajante sem porto", rumo à cidade de Salvador, sob as ratificações do vigário local Padre Teodoro: “- Velem por ela durante a travessia, sobretudo façam atenção na foz do rio, as águas são volúveis e o vento sopra forte. Deus que os acompanhe" (AMADO, 1999, p.4).

Duas alusões ao espaço fronteiriço e à imprevisibilidade a ele inerente são inferidas nesses diálogos em que a referência ao nome da embarcação "Viajante sem porto" e a volubilidade das águas, que conduzem à incerteza e ao inesperado, são dados marcantes para construir a idéia de fluidez e intercâmbio, sem, para tanto, desconsiderar as reviravoltas e 
tensões que essas hibridações podem desencadear.

Por sua vez, o caráter móvel da água pode ser lido enquanto similaridade a uma representação das instabilidades a que estão sujeitos os seres à era da modernidade tardia. Eliade (1991), ao estudar o simbolismo oriundo dos meios aquáticos, adverte que as águas são fons e origo, são reservatórios de todas as possibilidades de existência; elas precedem toda a forma e sustentam toda a criação. O contato com as águas supõe sempre uma regeneração e renascimento, porque dissolve o antigo e faz nascer algo novo. Desse olhar, compreende-se a travessia de Santa Bárbara pela água, a bordo de uma embarcação intitulada "Viajante sem porto" como representação das descontinuidades vividas na fronteira, um lugar de ambivalências do qual um novo pode emergir, conforme acontece.

Ainda, é relevante a associação feita pelo narrador da imagem da santa, de pé na popa da embarcação: "Ali, de pé, a majestosa efígie da santa católica semelhava carranca de barco, votiva figura de proa, entidade pagã e protetora" (Ibidem, p.4).

No lugar de fronteira, no espaço aquático, à frente da embarcação, a imagem desvela-se da simbologia tradicional e adquire a imprevisibilidade advinda do meio fronteiriço no qual se encontra e com quem estabelece uma negociação. Rio, água, carranca e imagem fundem-se na formação de um ícone não só associado à Santa Bárbara do catolicismo, mas também à reunião dela com elementos de cunho pagão relegados ao folclórico, ou popular.

Ao chegar à cidade, o inesperado acontece: a imagem 
transfigura-se em orixá, infiltra-se em direções desconhecidas e percorre caminhos inesperados, indo a lugares, e entre-lugares, negando-se a se dirigir aos espaços que a tradição lhes reservou, essencializando a condição sui generis do indivíduo na modernidade fluida em que, "ser moderno passou a significar, hoje em dia, ser incapaz de parar e ainda menos de ficar parado" (BAUMAN, 2001, p.37).

É nessa perspectiva de rearticulação ambígua que a imagem de Santa Bárbara, quando por ocasião do desembarque no cais da capital baiana, assume uma nova condição: a do orixá Iansã, sem, contudo, abandonar a identificação católica, vivenciando a condição híbrida, móvel, nômade. Desse modo, a própria identidade da imagem-santa-orixá é pautada no entre-lugar contingente e hífen que inova e interrompe as expectativas, que mais une do que separa.

\section{Referências}

AMADO, Jorge. O sumiço da santa: uma história de feitiçaria. 3. ed. Rio de Janeiro: Record, 1999.

AUGRAS, Monique. De Iyá Mi a Pomba-gira: transformações e símbolos da libido. In: MOURA, Carlos Eugênio Marcondes.Candomblé: religião do corpo e da alma. Rio de Janeiro: Pallas, 2002, p.17 a 44.

BASTIDE, Roger. O candomblé da Bahia: rito nagô. São 
Paulo: Companhia das Letras, 2006.

BERND, Zilá (org.). Escrituras híbridas: estudos em literatura comparada interamericana. Porto Alegre: Ed. Universidade/UFRGS, 1998.

BERND, Zilá; GRANDIS, Rita. Imprevisíveis Américas: questões de hibridação cultural nas Américas. Porto Alegre: Sagra: DC Luzzatto: ABECON, 1995.

BHABHA, Homi. K. O local da cultura. [Trad.]. Miriam Ávila, Eliana Lourenço de Lima Reis, Gláucia Renate Gonçalves. Belo Horizonte: Ed. UFMG, 1998. BAUMAN, Zigmund. Modernidade líquida. [Trad.] Plínio Centzien. Rio de Janeiro: Jorge Zahar, 2001.

CARPENTIER, Alejo. Prólogo. El reino de este mundo. La Habamas: letras Cubanas, 1989.

CHIAMPI, Irlemar. O realismo maravilhoso. São Paulo: Perspectiva, 1980.

ELIADE, Mircea. O Sagrado e o profano. São Paulo: Editora Martins Fontes, 2001.

ELIADE, Mircea. Tratado de história das religiões. 2.ed. São Paulo: Martins Fontes, 1998. 
ELIADE, Mircea. Imagens e símbolos: ensaios sobre o simbolismo mágico-religioso. São Paulo: Martins Fontes, 1991.

GRUZISNSKI, Serge. O pensamento mestiço. São Paulo: Companhia das Letras, 2001.

GUILHERMINO, Sebastião. Iansã do balé: senhora dos eguns. 6. ed. Rio de Janeiro: Pallas, 2004.

PESAVENTO, Sandra J. Fronteiras do milênio. Porto Alegre: Ed. Universidade/ UFRGS, 2001.

PRANDI, Reginaldo. Segredos guardados: orixás na alma brasileira. São Paulo: Companhia das Letras, 2005.

PRANDI, Reginaldo. Mitologia dos Orixás. São Paulo: companhia das Letras, 2001.

MARTINS, Cléo. Euá: senhora das possibilidades. Rio de Janeiro: Pallas, 2001.

MIGNOLO. Walter D. Histórias locais, projetos globais: colonialidade, saberes subalternos e pensamento liminar. [Trad.]. Solange Ribeiro de Oliveira. Belo Horizonte: Editora UFMG, 2003. 
TODOROV, Tzvetan. As estruturas narrativas. São Paulo: Perspectiva, 1979.

TODOROV, Tzvetan. Introdução à literatura fantástica. 4.ed. São Paulo: Perspectiva, 2010.

RAMA, Angel. La transculturación em la narrativa latinoamericana. In: la novela latinoamericana 1920-1980. Bogotá: Instituto Colombiano de Cultura, 1982.

REIS, Lívia Maria de Freitas. Transculturação e transculturação narrativa. In: FIGUEIREDO, Eurídice (org.). Conceitos de literatura e cultura. Juiz de Fora: UFJF, 2005, p.465- 488.

SANTIAGO, Silviano, $\mathbf{O}$ entre-lugar do discurso latino-americano. São Paulo: Rocco, 2000.

SWARNAKAR, Sudha. "The Fallen Woman in English and Brazilian Novels: A Comparative Analysis of D. H. Lawrence and Jorge Amado" University of Warwick, 1998. Tese de $\mathrm{Ph}$. D. não publicada. 


\title{
A Incidência do Fantástico em A Morte \\ e a Morte de Quincas Berro D'água e Dona Flor e Seus Dois IMaridos
}

\author{
Marilene Carlos do Vale Melo
}

\section{Resumo}

A narrativa fantástica constitui-se num gênero que, por lidar com o insólito, com uma realidade super-humana, com o sobrenatural ou com o inexplicável de qualquer tipo ou forma, remonta aos princípios da própria literatura. Assim, à luz de teorias sobre o Fantástico, defendidas por Todorov, Louis Vax dentre outros, nosso estudo se desenvolve destacando o clima do insólito ressaltado pelo discurso fantástico, circunstancialmente manifestado nas narrativas de Jorge Amado - a novela A morte e a morte de Quicas Berro d'Água o romance Dona Flor e seus dois maridos - . Nessas narrativas, o fantástico se opera ao nível das personagens que desafiam a morte e ultrapassam as leis da natureza. A ênfase do estudo recai sobre o jogo passado/presente, vida/morte (morte física e metafísica) das personagens Quincas Berro d’Água e Vadinho; o insubmisso Berro d’Água, cuja revolta vai além da rebeldia contra a sociedade e contra os limites da condição humana e as determinações do destino; e Vadinho, cuja morte em pleno carnaval, ajuda a definir seu caráter: como malandro, conhecia a ordem e a desordem e como espírito, volta à vida para realizar o desejo mais íntimo de Dona Flor.

Palavras-Chave: Fantástico. Insólito. Personagem. Morte. Vida. 164 


\section{Introdução}

A primeira ideia que se estabelece como conceito de Fantástico é que ele se define em relação aos conceitos de real e de imaginário; desenvolve-se partindo de um certo abandono da racionalidade. Porém, definir o que é Fantástico e que obras pertencem ao gênero, sempre foi uma tarefa difícil, considerando que o termo foi usado amplamente como sinônimo da literatura que se contrapõe ao realismo literário, ou mais especificamente que transgride as leis de causalidade. Louis Vax (1974, p.8) diz que "a narrativa fantástica gosta de nos apresentar, habitando o mundo real onde nos encontramos, homens como nós, postos de súbito em presença do inexplicável"; Cartex (Lê conte fantastique en france, p.8), afirma: "O Fantástico [...] se caracteriza [...] por uma introdução brutal do mistério no quadro da vida real". Todorov, fala que "na verdade o que distingue o fantástico narrativo é uma complexidade diante de um fato inacreditável, a hesitação entre uma explicação racional e realista e o acatamento do sobrenatural". Roger Caillois, em $A u$ Coeur du fantastique (p.161): "Todo o fantástico é ruptura da ordem estabelecida, irrupção do inadmissível no seio da inaceitável legalidade cotidiana".

Sendo assim, é possível observarmos a recorrência de termos como: Mistério, Mundo Irreal, Inexplicável, Vida Real, Inacreditável, Hesitação, Inusitado, Imaginário, Inadmissível, Absurdo, Sobrenatural, nos diversos conceitos, e que se manifestam nas narrativas fantásticas, constituídas como gênero, que, por lidarem com uma realidade super-humana, 
com o sobrenatural ou com o inexplicável de qualquer tipo ou forma, remontam aos princípios da própria literatura.

Quando, em uma narrativa, se dá um acontecimento inusitado que aparentemente não pode ser explicado pelas leis naturais, a hesitação experimentada pelas personagens ou pelos leitores, diante de um fato insólito, é que caracteriza o fantástico. O momento fantástico, segundo Louis Vax (1974, p.58), "aquele em que a imaginação se acha surdamente ocupada a minar o real [...]." Isto porque a narração fantástica caracteriza-se por manipular, sem entraves, o universo real, questionando a lógica racional dos acontecimentos absolutos e subvertendo a própria noção de realidade, de modo manifesto em seu discurso, passando a ser usado como recurso expressivo para evidenciar a ausência de fronteiras entre o real e o imaginário, o natural e o anormal. Logo, o fantástico se define como uma percepção particular de acontecimentos estranhos.

São alguns acontecimentos estranhos, inusitados, como a ruptura da realidade coesa e contínua, gerada pela desconstrução da realidade que conhecemos como verdadeira, que destacamos no estudo da incidência do fantástico em Jorge Amado.

Vale lembrar que o fantástico em Jorge Amado não é uma constante. $\mathrm{O}$ autor, circunstancialmente, usa esse recurso em algumas narrativas, como, por exemplo, $A$ morte e a morte de Quincas Berro d'Água e Dona Flor e seus dois marido, Nessas narrativas, o fantástico se opera ao nível das personagens que 
desafiam a morte e ultrapassam as leis da natureza. A ênfase do estudo recai sobre o jogo passado/presente, vida/ (morte física e metafísica) das personagens Quincas Berro d'Água e Vadinho. Nas duas narrativas, há o jogo de opostos manifestado na questão da dualidade da morte: a morte física $\mathrm{X}$ a morte metafísica. A primeira se contrasta com a morte metafísica e é entendida como ponto final da existência

Em A morte e a morte de Quicas Berro d'Água, Amado conta-nos, em tom lírico e divertido, a história de Joaquim Soares da Cunha, exemplar funcionário público, honesto pai de familia, massacrado pela mulher e pela sogra, que abandonou a vida respeitável familiar pela vida boêmia de Salvador, unindo-se a prostitutas e vagabundos, transformando-se no bêbado Quicas Berro d'Água. Instaura-se, assim, o conflito entre a ordem instituída pela sociedade dita burguesa e a liberdade da boemia.

Nessa narrativa, o clima do insólito já se manifesta no título, contrariando a expectativa convencional de uma narrativa do tipo biográfico - como Vida e morte de... - ao mesmo tempo, subverte a ideia do morrer como fato único, definitivo, não repetido. Observando rigorosamente o código do discurso fantástico, os acontecimentos são, desde as primeiras linhas, dados como problemáticos, a partir da referência à última frase de Quincas quando se joga no mar.. "Até hoje permanece certa confusão em torno da morte de Quincas Berro d’Água. Dúvidas para explicar detalhes absurdos, contradições no depoimento das testemunhas, lacunas diversas. Não há clareza sobre 
a hora, local e frase derradeira". (AMADO, 1976a, p.7).

O trecho acima remete à preocupação em buscar a verdade dos fatos, definindo o narrador como confiável e competente para narrar tais fatos. Porém, feitas as investigações necessárias, esse narrador confessa a irresolução do problema. Assim, duas versões permanecem: a da família, apoiada por vizinhos e conhecidos e a dos amigos de Quincas, da vida boêmia dos seus últimos anos de vida.

As versões remetem à dualidade: morte física $\mathrm{X}$ morte metafísica. A primeira: a tranquila morte matinal, numa pocilga miserável da Ladeira do Tubarão, sem testemunhas, sem aparato, sem palavras; a segunda, a morte metafísica, no mar, comentada e propalada na noite, presenciada por testemunhas idôneas que viram Quincas se jogar no mar, enquanto ouviam sua última frase, repetida, mais tarde, de boca em boca. "Segundo um trovador do mercado, passou-se assim":

No meio da confusão

Ouvia-se Quincas dizer:

“- Me enterro como entender

na hora que resolver. Podem

guardar seu caixão pra melhor ocasião.

Não vou deixar me prender em cova rasa no chão."

E foi impossível saber o resto de sua oração.

(AMADO, 1976, p.39, grifos do autor).

A linha do tempo desenvolve-se em três momentos importantes: a $1^{a}$ morte - moral (quando deixa a família para viver 
a vida boêmia): a $2^{\mathrm{a}}$ morte-física (no quarto da Ladeira do Tubarão) e a $3^{\mathrm{a}}$ morte - metafísica (no mar, como desejou). A ordem dos três momentos está marcada pela linha do tempo lógico, cronológico.

Assim, avisada da morte de Quincas, a família, preocupada em recuperar o nome e a imagem do homem digno que fora, tenta enterrá-lo segundo as normas burguesas. Entregue a uma funerária, o corpo de Quincas, livre dos trapos que usava na nova vida boêmia, transfigurou-se: "Penteado, barbeado, vestido de negro, camisa alva e gravata, sapatos lustrosos [..]. (p. 18)", voltou a ser Joaquim Soares da Cunha. Durante o velório, se evidencia o primeiro momento do Fantástico, que acontece somente para a filha de Quincas, enquanto velava o corpo do pai, no quarto imundo da ladeira do Tubarão:

Fisionomia melancólica, fitou o cadáver [...] Pousou os olhos no rosto barbeado. E levou um choque, o primeiro. Viu o sorriso. Sorriso cínico, imoral, de quem se divertia [...] um riso que ia se ampliando, alargando-se, que aos poucos ressoava na pocilga imunda. Ria com os lábios e com os olhos, olhos a fitarem o monte de roupa suja e remendada, esquecida num canto pelos homens da funerária. O sorriso de Quincas Berro d’Água. E Vanda ouviu as sílabas destacadas com nitidez insultante, no silêncio fúnebre: 
- Jararaca!

Assustou-se Vanda [...] Nem agora morto e esticado no caixão [...] ele se entregava. Ria além da boca e com os olhos, não era de admirar-se começasse a assobiar. E além do mais, um dos polegares [...] não estava devidamente cruzado sobre outro, elevando-se no ar, anárquico e debochativo.

- Jararaca! - disse de novo, e assobiou gaiatamente.

(AMADO, 1976a, p.18-19)

A surpresa e a hesitação tomam conta de Vanda, pensou: "Será que estou enlouquecendo? Sentiu faltar-lhe o ar... sua cabeça rodava." (p. 19).

A chegada de outra personagem, a irmã do morto, tia Marocas, não alterou a situação. Entrando no quarto, "Viu a sobrinha decomposta na cadeira, lívida, os olhos pregados na boca do morto." Quincas continuou com o sorriso cínico e debochado, além de falar insultos.

Ampliou-se o sorriso canalha de Quincas ao enxergar o vulto monumental da irmã. Vanda quis tapar os ouvidos, sabia, por experiência anterior, com que palavras ele amava definir Marocas, mas que adiantam mão sobre as orelhas para 
conter voz de morto? Ouviu:

- Saco de peidos! (p.19).

Até este momento, o fantástico se apresenta apenas para a filha, Vanda.

O segundo momento da narrativa criou o máximo efeito do fantástico e orientou para a segunda morte de Quincas. Tudo começou com a chegada dos amigos vagabundos e companheiros de farra de Quincas: Curió, Negro Pastinha, Cabo Martinho e Pé-de-Vento, que, de certa forma, constituem o elemento desarticulador da ordem moral e possibilitam a manifestação do fantástico.

Quando surgiram na porta do quarto, Pé-deVento adiantou a mão em cuja palma estava pousada a jia de olhos saltados. Ficaram parados na porta, uns por trás dos outros. Negro Pastinha avançava a cabeçorra para ver. Péde-Vento, envergonhado, guardou o animal no bolso. A família suspendeu a animada conversa, quatro pares de olhos hostis fitaram o grupo escabroso. Só faltava aquilo, pensou Vanda. Cabo Martim, que em matéria de educação só perdia para o próprio Quincas. Retirou da cabeça o surrado chapéu, cumprimentou os presentes. (p.26). 
Incomodados com a presença deles, todos da família combinaram voltar no dia seguinte para realizarem o enterro. Deixaram o "defunto" à responsabilidade dos quatro amigos de Quincas. Juntos, começaram a bebedeira, até decidirem ir à festa de mestre Manuel e buscar as mulheres. Agora, morto Quincas e com a cachaça enfraquecendo a força da censura, surgiu a disputa para saber quem seria o substituto de Quincas no coração de Quitéria do Olho Arregalado.

Ele adora ouvir uma cantiga. Cantavam os quatro... Quincas não perdia nem um só gole, nem um som, gostava de cantigas. Quando já estavam fartos de cantar, Curió perguntou:

- Não era hoje de noite a moqueca de mestre Manuel?

- Hoje mesmo...

Quincas estalou a língua. Já estavam atrasados, pois ainda tinham de ir buscar as mulheres, Curió expôs suas dúvidas:

- Tu quer ir?

- Tou por acaso aleijado para ficar aqui? Puseram Quincas em pé. Negro Pastinha comentou:

- Tá tão bêbado que não se aguenta... Vambora, Paizinho.

Quicas satisfeito da vida, num passo de 
dança, ia entre o Negro Pastinha e o Cabo Martim, de braços dados...

(AMADO, 1976a, p. 33)

O fantástico da situação utilizou-se desse momento para tirar os melhores efeitos. Enquanto Quincas levantou-se do caixão e acompanhou os amigos pelas ruas de Salvador, em última peregrinação, buscou realizar seu desejo, de escolher o seu próprio destino, o de morrer no mar. Assim, cumprindo o último ritual de brigas e bebedeiras, num misto de ficção e realidade, com lances fantásticos de mistério, sobrenatural e inesperado, o herói morreu pela segunda vez, no mar, como um velho marinheiro, livre das convenções sociais.

No meio do ruído, do mar em fúria, do saveiro em perigo, à luz dos raios, viram Quincas atirar-se às ondas e ouviram sua frase derradeira. Penetrava o saveiro nas águas calmas do quebra-mar, mas Quincas ficara na tempestade, envolto num lençol de ondas e espuma, por sua própria vontade. (p.38). 
Comparando os dois textos em estudo, constatamos que a morte física de Quincas e a de Vadinho aconteceram em circunstâncias semelhantes. Como Quincas Berro d'Água, Vadinho, o homem da noite, do jogo, da vadiagem, da rua e da alegria, amigo de jogadores, marginais e sem lugar na estrutura social, morreu na rua, em pleno domingo de carnaval. Esse é o ponto inicial da narrativa, um momento associado ao tempo carnavalesco, tempo de alegria obrigatória e planejada, com o inesperado da morte do maior folião baiano de todos os tempos: Vadinho.

A história de Dona Flor pode ser apresentada em quatro momentos distintos. O primeiro momento é o da viuvez de Flor, quando morreu seu marido, em pleno Carnaval, numa situação que ajudou a definir o caráter de Vadinho. Daí, a narrativa volta ao passado e o narrador nos apresenta a relação Vadinho/Flor.

Falando sobre a viuvez de Flor, Jorge Amado define a personalidade de Vadinho como malandro, caloteiro, jogador, mulherengo, amigo da noite, capaz de trazer à sua honrada e leal esposa os maiores sofrimentos. Há aqui muitos relacionamentos importantes. Por um lado, a visão exterior de Vadinho como malandro e rufião e irresponsável, é complementada por uma visão interna feita pelas recordações de Dona Flor e motivada pelo seu amor por esse homem tão seu oposto e, ao mesmo tempo, tão complementar a ela e ao seu estilo de vida.

Ocorreu, então, o jogo de contraste: a descrição do 
Vadinho feito pelas comadres e amigas de Flor (um Vadinho exterior), e a do Vadinho da memória de dona Flor, capaz de fazê-la ver todo um outro lado da vida e do relacionamento humano que a existência burguesa não deixava perceber. $\mathrm{Na}$ memória de Flor, Vadinho surgia como malandro e como ser do movimento e da própria vida. Como homem que fez com que ela pudesse se transformar plenamente em mulher capaz de transcender as convenções sociais da hierarquia, do poder, do dinheiro e, até mesmo, das propostas monogâmicas da religião e da sociedade, significando, para dona Flor, um modelo de liberdade.

Vale lembrar que durante todo o período de viuvez de Dona Flor, ficou evidente o esforço das amigas no sentido de fazer com que ela se relacionasse novamente com o mundo exterior, saindo do luto. Dona Flor resolveu abandonar seu estado de individualização dado pela viuvez e luto fechado e voltou ao reino dos amigos e do mundo. A perda de Vadinho, com sua morte, significou, para Flor, a falta do homem, o que logo foi superada com o segundo casamento, em condições opostas e bem mais satisfatórias. Este é o segundo momento da narrativa, quando Flor entrou em outra relação conjugal, casando com o farmacêutico, Teodoro.

O casamento com Teodoro transcorreu com tamanha tranquilidade que dona Flor escreve em carta a sua irmã Rosália: "O tempo passa e o doutor não muda. A mesma palidez, o mesmo sistema, o mesmo tato, sempre igual, um dia atrás do outro. Posso dizer o que vai acontecer a cada instante, 
no passar das horas, e sei cada palavra, porque hoje é igual a ontem" (AMADO, 1976b, p.255).

Comparado ao segundo marido, Teodoro, Vadinho é o sem-vergonha debochado, amoral, diferente de Teodoro. Disso Flor tinha consciência. Porém ela começou a pensar em Vadinho e a desejá-lo, como se sua vida estivesse incompleta, sem o outro lado que Vadinho representava e exprimia. Se estava satisfeita com o segundo casamento (é assim que o texto nos permite observar), por que aceitar "aquela" vida de antes, cheia de dúvidas, insatisfação e tormento, ao lado de Vadinho?

Assim, no quarto e último momento da narrativa, o fantástico se evidencia com a presença de Vadinho na alcova de Dona Flor.

No leito de ferro, nu [...] estava Vadinho deitado, a la godaça, e sorrindo lhe acenou com a mão. Sorriu-lhe em resposta, dona Flor. Quem pode resistir à graça do pedido, àquela face de moceneta e de cinismo...? Nem uma santa da igreja, quanto mais ela, dona Flor, simples criatura.

- Meu bem... - aquela voz querida, de preguiça lenta.

- Por que veio logo hoje? - perguntou Flor.

- Porque você me chamou. E hoje me 
chamou tanto que eu vim... - como se dissesse ter sido o seu apelo insistente e intenso, a ponto de fundir os limites do possível e do impossível Pois estou eu aqui, um bem, cheguei indagorinha...

(AMADO, 1976b, p. 293)

É o momento fantástico, o acontecimento inusitado, inacreditável, marcado pelo sobrenatural, onde se destaca a mistura do mundo material com o sobrenatural e apresentação de uma personagem, que, em vez de lutar para resolver contradições e dilemas íntimos, aceita os paradoxos e as incoerências que definem bem o humano. E, justamente porque se recusa a fazer escolhas e aceitar a vida como experiência múltipla, incoerente, se fortalece como ser humano.

O Fantástico aqui se opera ao nível das personagens: Flor e Vadinho. Diferente de Vanda que se surpreendeu com as reações de Quincas, morto, não há hesitação nem surpresa por parte de Flor. Assim, sem hesitação nem surpresa, a volta de Vadinho representa a realização de um grande desejo de Flor.

A insistência de "posse" de Flor se antepõe à resistência dela. É preciso lembrar que desde o início da narrativa, o autor deixa passar para o leitor o caráter íntegro e pudico, além do sentido de moralidade que caracteriza a personagem Flor. Isto cria um certo antagonismo entre o caráter de Flor e o de 
Vadinho. Flor nunca aceitou a amoralidade de Vadinho. Porem, o pudor e a moralidade de Flor não foram suficientemente fortes para reprimir seus desejos. Daí porque ela aceitou a volta de Vadinho, porque no fundo ela precisava de um homem como ele. Sendo pudica e moralista, como se explica a "aceitação" passiva da volta de Vadinho? Mas não era a vida tranquila ao lado de Teodoro que a satisfazia. Assim, se tinha a oportunidade de realizar e materializar (pelo menos essa era a sua ótica) seu grande desejo, Flor não deixou escapar. Isso fica evidente no jogo de sedução articulado por Vadinho, repetindo momentos da vida dos dois, como quando ele estava vivo:

Por duas ou três vezes naquele fim de tarde, Vadinho lhe repetira com vOz matreira, num sorriso de motejo: - Vamos ver quem pode mais, minha santa... Tu com teu doutor e teu orgulho e eu...

- Tu com o quê?

- Eu com meu amor... (p. 303).

Daí, Flor se dividiu entre a existência calma e pacífica com o segundo marido e a relação atribulada inconstante com Vadinho "morto" para as outras personagens, porém "muito vivo" na sua vida íntima. Por isso, se questiona, "aquele era um problema novo, nele não pensara Flor e nem soube contestar". Preocupada com a volta de Teodoro, manda Vadinho embora e diz: 
Lá vem ele, Vadinho, vai-te embora... Fiquei contente, muito contente, nem sabes, de te ver... Foi bom demais...

- Por que hei de ir, me diga?

- Ele chega e vai te ver aqui, que é que eu vou dizer?

- Tola, ele não me vê, só quem me vê és tu, minha flor de perdição.

(AMADO, 1976b, p 294)

Após saber que somente ela, Flor, pode "ver" Vadinho, teve a sensação de alívio. Mas essa sensação remeteu ao sentido de perda do marido, pela segunda vez, porque Vadinho voltou à vida boêmia de antes. Nesse sentido, percebemos um tom de dor e tristeza que se manifesta no texto mascarando esse sentimento, se confirma com a afirmativa de Flor: "Antes assim [...]", porque ela tinha consciência, naquele momento, que Vadinho não significava a mudança de seu comportamento, mas sim, a simples realização de seu desejo mais íntimo. É uma situação crítica porque fez com que ela se decidisse por tê-lo a seu lado não importando as implicações morais de seu desejo.

- Encornou... - disse Vadinho aplicando o termo justo. - Agora, nós, meu bem $[\ldots]$

- Aqui, não... - Pediu dona Flor, gastando os últimos resquícios de pudor 
e de respeito ao segundo esposo. Vamos pra sala...

Na sala, as portas do céu se abriram, irrompeu o canto de alegria. Onde já se viu vadiar de camisola? Dona Flor tão despida quanto ele, um da nudez do outro se vestindo e completando. Lança de fogo a traspassou, pela segunda vez Vadinho the comeu a honra, primeiro a de donzela, agora a de casada [...] Lá se foram pelos prados da noite até a fímbria da manhã. Nunca se dera assim, tão solta e tão fogosa, tão de gula acesa, tão em delírio. Ah! Vadinho, se sentias fome e sede, quer dizer de mim, mantida em regime magro e insosso, sem sal e sem açúcar, casta esposa de marido respeitador e sóbrio? Que me importa meu conceito na rua e na cidade, meu nome digno? Minha honra de casada, que me importa? Toma de tudo isso em tua boca ardida... queima em teu fogo a minha decência inata, rasga com tuas esporas meu pudor antigo, sou tua cadela, tua égua, tua puta.

(AMADO, 1976b, p. 35) 
Como espírito, Vadinho conhecia a vida e a morte e como malandro conhecia a ordem e a desordem, o mundo das relações pessoais e o mundo das leis e dos regulamentos impessoais. Comparando a vida de casada com Teodoro, os bens materiais que ganhou no segundo casamento, com relação dos dois antes de sua morte, ele falou a Dona Flor:

A casa própria, a fidelidade conjugal, o respeito, a ordem, a consideração e a segurança. Quem te dá é ele, pois o seu amor é feito dessas coisas nobres (e cacetes) e delas todas necessitas para ser feliz. Também do meu amor precisas para ser feliz, desse amor de impurezas, errado ou torto, devasso e ardente, que te faz sofrer. Amor tão grande que resiste à minha vida desastrada, tão grande que depois de não ser voltei a ser e aqui estou.

E completa Vadinho, sabiamente: "Quando era só eu, tinhas meu amor e te faltava tudo, como sofrias! Quando foi só ele, tinhas de um tudo, nada te faltava, sofrias ainda mais. Agora, sim, és Dona Flor inteira como deves ser".

(AMADO, 1976b, p.366) 
$\mathrm{Na}$ condição de morto que voltou ao mundo dos vivos, Vadinho não mudou, em nada difere daquele homem quando vivo. Continua o mesmo malandro de antes. De certa forma, o autor nos mostrou que a possibilidade do seu "retorno" ao mundo dos vivos, pela utilização de elemento fantástico, não modificou seu comportamento. Era de se supor, que na condição de morto atingisse a redenção e a purgação das culpas. Porém, a consciência que está morto e, portanto, isento das censuras dos vivos, tendo sua "volta" percebida apenas por Flor, sentia-se livre para pensar e agir como antes, tanto que se considerava, também, marido de Flor. Assim, decidiu ficar e participar ativamente do cotidiano de Flor, dando-se o direito de ironizar e fazer gozação ao referir-se a Teodoro, reafirmando que os dois (ele e Flor) estão casados.

- Me deixa dormir, cheguei faz pouco.

- Tu não pode dormir na sala

- O que é que tu tem?

- Já te disse, fico sem jeito.

$[\ldots]$

- Tá bom, tola. Vou para o quarto. O meu colega já saiu?

- Colega?

- O teu doutor... Não somos os dois casados contigo, meu bem [...] (p.301). 
Livre da "visão" das outras personagens e das sensações que poderiam ser atribuídas a seus atos, volta à vida boêmia, ao convívio dos amigos malandros e, principalmente a assediar as alunas de Flor. Como fazia antes da morte. Assim, por exemplo, quis se certificar da originalidade dos seios "[...] da abundante Zulmira Simões Fagundes, crioula augusta, [..]. quadris soltos independentes, seios de bronze (ao menos pareciam) [...] (AMADO, 1976b, p. 302).

Vadinho quis tirar a limpo de uma vez por todas o enigma dos seus seios: seriam mesmo de bronze ou apenas de extraordinariamente rigidez. Para tanto, elevou-se no ar e pondo-se com os pés para cima e a cabeça para baixo, expiou pelo decote do vestido da primorosa da nação nagô. (p.302).

O que aconteceu, no caso de Dona Flor, não foi a recusa do ambíguo, mas a busca e a aceitação plenamente consciente de dois homens diferentes e, com eles, formar um triângulo amoroso perfeito. Até o final da narrativa, Flor passou a conviver com os "dois maridos" nesse nível de existência ficcional fantástica. 


\section{Considerações Finais}

No mundo real que é exatamente o nosso, a produção de um acontecimento que não pode ser explicado pelas leis deste mesmo mundo familiar, ou se trata de uma ilusão, ou então o acontecimento realmente ocorreu. O fantástico ocorre nesta incerteza; ao escolher uma ou outra resposta, deixa-se o fantástico para entrar num gênero vizinho, como o estranho, por exemplo.

O que há no final da narrativa de Quincas Berro d'Água é a história de um homem que abandonou a vida de cidadão passou a viver na boemia. Quincas Berro d'Água é uma personagem que desafiou a morte. Ele não é um insubmisso, mas sua revolta foi muito além da rebeldia contra as mazelas sociais e se expande para uma revolta contra os limites da condição humana e as determinações do destino.

A sua morte em alto-mar significa um grito de liberdade, porque, irmanado ao povo, aos vagabundos e desqualificados, e ao deixar de ser o pobre Joaquim Soares da Cunha, explorado pela família, ganhou uma grandeza que não possuía antes, a de escolher o seu próprio destino, ter a morte desejada e escolhida: morrer no mar, com todas as honras de velho marinheiro.

Há ainda diversas interpretações da sociedade sobre a morte nas condições da morte do herói, Quincas. A morte de um homem, por mais testemunhada que seja por autoridades competentes e objetivas sempre deixa portas abertas para o mistério, para as condições próprias do ser humano. Além 
disso, quanto mais duvidosa for a morte, mais o espírito da morte sobrevive social e psicologicamente.

Por outro lado, predomina na narrativa de Dona Flor e seus dois maridos a luta psíquica da personagem Flor, na tentativa de superar os preconceitos impostos pela sociedade. Sem se render a esses preconceitos, se entregou aos desejos e instintos e, enfim, se dá o direito de amar dois homens. Jorge Amado põe em cena uma heroína que não precisou mais escolher entre o bem e o mal, isto porque, dividida entre o falecido e sensual Vadinho e a nova paixão pelo metódico Teodoro, ela ficou com os dois.

Contrariando o que afirma Todorov que, no fim de uma história, o leitor, quando não a personagem toma, contudo, uma decisão, opta por um, ou outra solução, saindo desse modo do fantástico, o final das duas narrativas estudadas, o fantástico permanece e possibilita a realização dos desejos intensos das personagens: a segunda morte de Quincas Berro d'Água no mar como velho marinheiro e em Dona Flor e seus dois maridos é a volta e aceitação de Vadinho e decisão de Flor de ficar com os dois maridos.

\section{Referências}

AMADO, Jorge. A morte e a morte de Quincas Berro d'Água. In Os velhos marinheiros. Rio de Janeiro: Livraria Martins Editora, 1976a. 
. Dona Flor e seus dois maridos. Rio de Janeiro:

Livraria Martins Editora, 1976b.

RODRIGUES, Selma C. O fantástico. São Paulo: Ática, 1988.

TODOROV, T. As estruturas narrativas. São Paulo: Ed. Perspectiva, 1979.

TODOROV, Tzvetan. Introdução à literatura fantástica. Trad. De Maria Clara Corra Castello. São Paulo: Perspectiva, 1975.

VAX, Louis. A arte e a literatura fantástica. Lisboa: Arcádia, 1974. 


\title{
Anarquia e Humor: a representação do povo em sua subversão dos valores dominantes
}

\author{
Luiz Felipe de Queiroga Aguiar Leite
}

\section{Resumo}

O presente artigo analisa a representação do povo na obra de Jorge Amado com enfoque em seu papel de subversão dos valores dominantes partindo de três tópicos: anarquia, à luz de José Maurício Gomes de ALMEIDA, para quem os personagens de Jorge Amado possuem uma liberdade romântica de raiz fundamental; o humor, analisado a partir da teoria da carnavalização de BAKHTIN e a mestiçagem, trabalhada em diálogo com a antropologia por Ilana Seltzer GOLDSTEIN.

Palavras-chave: Anarquia. Humor. Mestiçagem. Jorge Amado.

\section{Abstract}

This article examines the representation of people/ characters in Jorge Amado's novels, focusing on its role in subverting the dominant values from three topics: anarchy, following the critical view presented by José Maurício Gomes de ALMEIDA, for whom Jorge Amado's characters have a fundamental liberty romantic root; humor, parting from the theory of carnivalization of BAKHTIN and mestizaje, char- 
ted in dialogue by anthropologist Ilana Seltzer GOLDSTEIN.

Key words: Anarchy. Humor. Mestizaje. Jorge Amado.

\section{Introdução}

No âmbito da crítica que oscila entre uma defesa da criação imaginária do autor, da representação popular de seus personagens, da construção de um modelo social sincrético e mestiço há uma certa controvérsia que "define" a obra de Jorge Amado. Um tipo de condenação que vê suas obras como tipificadora, pitoresca, simplória linguagem de costumes; principalmente as obras da segunda fase iniciada com Gabriela, Cravo e canela (1958). Essa primeira observação é fundamental para o desenvolvimento de nossa proposta. As obras do autor se dividem em dois momentos distintos: antes e depois de Gabriela, cravo e canela. Um primeiro momento de obra dita engajada, tendo em vista seu vínculo com o partido comunista, e um segundo momento em que esse vínculo já não mais orientava sua produção artística, mas, de acordo com o autor, não o impediu de fazer uma literatura comprometida com as questões sociais. Dizia Jorge Amado que descobriu uma forma mais revolucionária de fazer literatura: o humor.

A crítica de postura mais tradicional considera a primeira fase do autor e a encaixa nos padrões da literatura regional. O romance Terras do sem fim (1943) representaria sua forma mais bem acabada. Já a sua segunda fase é conside- 
rada de simples narrativas pitorescas, crítica de costumes de tensão mínima, como diz Bosi (2006, p.405-407) utilizando o esquema teórico de Goldmann; uma literatura comandada pelo gosto do mercado, ou seja, claramente, uma literatura feita para apenas para vender, como diz Walnice Galvão (1976, p.13); ou mesmo narrativas descuidadas e desleixadas, sem valor estético.

É justamente esta segunda fase que mais interessa ao presente trabalho. Não pretendemos realizar um confronto teórico com essas posições. Outros trabalhos já começaram a estabelecer essas relações (ALVES, 2001). O que nos interessa nesta segunda fase é apresentá-la como a mais bem orientada de sua obra, mas orientada sob outros valores que não o engajamento partidário e corroborar com a opinião do autor sobre o comprometimento social de sua literatura, utilizando para tal o estudo que a aqui se apresenta: a anarquia e o humor como elementos estéticos e ideológicos que trabalham a representação do povo em sua subversão dos valores dominantes.

Antes de entrar especificamente nos tópicos propostos, anarquia e humor, esclarecemos o conceito de povo utilizado no trabalho.

\section{Povo:}

Diz José Maurício Gomes de Almeida (1986):

[...] o povo em Jorge Amado não aparece quase nunca sobre a forma de uma classe, retratado no impulso 
de movimentos coletivos, mas através do esforço de resistência de alguns indivíduos que compõem este "povo" à opressão, à injustiça, à desumanização da vida de cada dia.

(ALMEIDA, p.73)

O povo de Jorge Amado não é, sem dúvida, a massa totalizante que compõem o país chamado Brasil, mas também não são apenas os miseráveis, os em condição de pobreza absoluta. O povo é, principalmente, aqueles grupos que através da resistência, seja à opressão, à injustiça ou à desumanização cotidiana, como nos diz Almeida, criam alguma autonomização, se inscrevem socialmente, politicamente ou culturalmente.

Portanto, lemos a representação do povo na obra de Jorge Amado como trabalho estético que visa, através da subversão dos valores dominantes, à incorporação do elemento popular nos regimes políticos e sociais, elemento estético que construiu e constrói o imaginário baiano e brasileiro.

Anarquismo segundo José Maurício Gomes de Almeida:

[...] a visão de mundo subjacente à obra amadiana tende muito mais para um certo anarquismo instintivo, de raiz acentuadamente românti$\mathrm{ca}$, do que qualquer outra forma de 
marxismo. Como afirmamos, o valor máximo no universo do escritor é a liberdade concebida em termos de liberdade individual: possibilidade para cada indivíduo que compõe o corpo social de realizar plenamente suas potencialidades humanas. A opressão do forte, as desigualdades econômicas são evidentemente combatidas como entraves a esta aspiração ideal, mas igualmente o são todas as formas de comportamento institucionalizado dominantes na sociedade moderna, com seu potencial castrador, com sua mal disfarçada aspiração a padrões impositivos e massificados do viver. É este "fundamental anarquismo" que se encontra no centro do universo ficcional do criador de Quincas Berro d'água

(ALMEIDA, p.75).

Uma constante dos personagens de Jorge Amado é a negação das formas institucionalizadas da vida, representada pela caracterização da classe burguesa, quase sempre rígida, moralizadora, tacanha e redutora.

Dessa negação, advém a proposta de Almeida: os personagens de Jorge Amado têm um anarquismo funda- 
mental de raiz romântica. Lembremos que o romantismo nos seus primórdios era revolucionário ${ }^{1}$ Sob o lema da Revolução Francesa o Romantismo fez ascender os valores do povo em sua ânsia de liberdade. Uma mudança estrutural fundamental para a nova sociedade burguesa que surge desenvolvendo os valores do capital. Lembremos com Marx (2010, p.27) que antes de se tornar hegemônica, "a burguesia desempenhou na história um papel revolucionário decisivo”. Antes grupo oprimido sob o julgo dos senhores feudais, tomam o poder. Se sobre a, por vezes pejorativamente chamada, classe burguesa de hoje não se pode mais reconhecer os traços populares que a caracterizava, a sua ânsia de autonomia, de oposição ao julgo

1 A estética romântica em seu início se vinculava ao povo, aos seus costumes, a suas crenças, dando-lhes voz na "praça pública”. Tomemos Shakespeare como caso salutar, ele é redescoberto pelos românticos e só começa a ser visto como grande autor a partir da leitura destes. Em defesa do povo, a estética romântica também se punha contra a guerra, como vemos nas telas do pintor espanhol Francisco de Goya ou em poemas como de Coleridge (apud THOMPSON, p.54) sobre a morte de um soldado comum:

"De nome sem registro/Morreu o homem insignificante,/Mas ele deixou pra trás alguém que nunca rezou suas orações diárias/Sem dele esquecer, que a cada história/Da guerra distante prestando total atenção,/Ficava pálida e trêmula. Na porta de seu chalé/A infeliz sentará, e com o olhar triste/Olhará para a planície, onde sobre os passos dele, que se afastavam,/ Caiu seu último olhar. Nunca mais ela verá/Seu marido morto, mas torturada de vã esperança/Continuará olhando...”. Um homem simples, do povo, não era tema para arte de motivos clássicos com seu ideal de beleza que visava à clareza, à simetria e perfeição dos traços, ao Belo enfim. 
aristocrático e, portanto, dominante, permanece ainda nas camadas populares que um dia, ela, a burguesia, foi. Ânsia que ideologicamente, como sabemos, foi traduzida nas palavras liberdade, igualdade e fraternidade da revolução.

Liberdade, então, torna-se uma palavra chave para caracterizar esse sentimento popular fraterno, igualitário e livre que se opõe aos valores dominantes. É neste sentido que é utilizado neste artigo o termo anarquia. Do grego anarkhos, sem governo, ou seja, não caos e desordem, mas oposição ao poder coercitivo que subjuga e limita o florescimento das potencialidades individuais.

Os heróis de Jorge Amado são sempre os vagabundos, as putas, os malandros, os bêbados, mulheres, etc...; figuras que vivem à margem da engrenagem social. Pedro Bala, de Capitães da areia (1937), é um menino de rua, capoeirista, ladrão e chefe de bando. Lívia, em Mar morto (1936), após a morte do marido assume o leme do Paquete voador, o barco de Guma, negando o caminho, à época, destinado às mulheres: o operariado ou a prostituição. Vadinho, de Dona flor e seus dois maridos (1966), é o malandro por excelência. Sedutor, atraente, vadio. Pedro Arcanjo representa o povo de santo: temática recorrente e fundamental na construção estética do autor. Arcanjo, com sua pesquisa e experiência direta, representa o conhecimento do povo em oposição ao conhecimento acadêmico. É o Ojuobá, os olhos do rei Xangô, título recebido no candomblé que lhe dá direito a tudo ver e tudo saber da lei do santo. Quincas berro d'água nega a vida bur- 
guesa antes e depois de morto. Rejeita o velório tradicional que sua familia lhe quer dar.

Não é uma perspectiva de classe que motiva os personagens, mas este anarquismo de que nos fala Almeida. E aí se impõe uma diferença que torna substancial as divisões de fase na obra de Jorge Amado. Por mais que esse anarquismo esteja presente ao longo das duas fases de sua obra, alguns "finais infelizes" da primeira fase reduzem as possibilidades estéticas e ideológicas na representação dos personagens rendendo-se aos padrões da literatura partidária. Pedro Bala, e outros capitães da areia, acabam "encaminhados na vida", assumindo profissões instituídas e seguindo seus valores. Baldo, de Jubiabá (1935), tem destino semelhante ao se tornar sindicalista e seguir à risca as regras do sindicato. É o que não acontece com os personagens da segunda fase. Gabriela é um de seus principais representantes. Ela não é simplesmente ingênua ${ }^{2}$, mas sua ingenuidade é representa2 É possível falar-se de uma confusão entre a ingenuidade do povo e infantilidade. Possivelmente, a mesma que confundiu a literatura infantil nos seus primórdios com a suposta ingenuidade do povo, como nos diz Lígia Cademartori (2006, p.39) nas adaptações de Charles Perrault dos contos populares: "Na base do trabalho de adaptação, está o conceito que a ingenuidade da mentalidade popular identifica-se com a ingenuidade da mentalidade infantil. A vocação pedagógica de Perrault é secundária e confusa. [...] Talvez nesse momento tenha sido inaugurada a confusão que fortaleceu os laços entre literatura popular e literatura infantil e que tem por base a aproximação de duas ignorâncias: a do povo, devido a sua condição social, e a da infância, devido à idade". 
ção estética do povo que nega o patriarcalismo dominante da cidade de Ilhéus. A ingenuidade em Gabriela não é sinal de inferiorização e infantilização, mas caracterização que a torna agente transformador, não mero objeto, como diz Goldstein (2003, p.162). Ela aparece no romance em justa oposição ao personagem sofrido de Sinhazinha assassinada pelo marido e que representa o auge do patriarcalismo burguês tacanho e violento da cidade e dos coronéis. Nos diz Swarnakar (1998, p.205) que Gabriela introduz mudanças nas normas sociais. É nesse sentido que ela é um agente: "Gabriela onwards his attention is drawn towards the exploitation of women by men, and he thus assumes the position of a social critic, now seeing even sex as a form of exploitation in a patriarchal society" (Ibidem, p. 174).

Gabriela também usa o sexo, outra forma de subversão das mais utilizadas dos valores dominantes. No caso específico da personagem, dos valores patriarcais burgueses da província de Ilhéus. Ela divaga:

Coisa mais tola, sem explicação: por que os homens tanto sofriam quando uma mulher com quem deitavam deitava com outro? Ela não compreendia. Se Seu Nacib tivesse vontade, bem que podia ir com outra deitar, nos seus braços dormir. Ela sabia que Tonico dormia com outras, Dona Arminda contava que ele tinha um 
horror de mulheres. Mas, se era bom deitar-se com ele, brincar com ele na cama, por que exigir que fosse só ela? Entendia não. Gostava de dormir nos braços de um homem. Não de qualquer. De moço bonito, como Clemente, como Tonico, como seu Nilo, como Bebinho, ah! Como Nacib. Se o moço também queria, se a olhava pedindo, se sorria para ela, se a beliscava, por que recusar, por que dizer não? [...] Havia uma lei, não era permitido. Só o homem tinha direito, não o tinha a mulher?

(AMADO, p. 313).

$\mathrm{Na}$ visão romântica e subversiva de Gabriela, as relações entre homens e mulheres não dão direito a posses ou a limitação do número de parceiros. Tanto que mesmo gostando de deitar com seu Nacib, manteve relações com outros homens. Deitar só por deitar, diz a personagem, sem as restrições impostas da sociedade, sem as regras restritivas do matrimônio e as exigências do convívio social burguês e patriarcal.

Para Gabriela não há final que a institucionalize, como Pedro Bala ou Baldo. Ela mantém seu instinto de liberdade, só maculado porém não vencido pelo casamento que por um tempo aceita e depois volta a negar. Anárquica, 
ela é agente transformador das normais sociais de conduta imprimindo o valor da liberdade em oposição aos valores dominantes.

\section{Humor}

Não se empreendeu um estudo sério do riso popular, diz Bakhtin nos idos de 1965 quando escreveu A cultura popular na idade média e no Renascimento. De lá pra cá os estudos sobre o humor, o riso, apesar de terem se desenvolvido, ainda mantiveram uma marca da inferiorização que a temporalidade lhes legou. No âmbito das letras, a divisão aristotélica entre arte de imitação de homens superiores e arte de imitação de homens inferiores contribuiu para a manutenção desse caráter marginal, desfavorecendo o humor. Sem o intuito de abarcar todas as suas facetas e sua historicidade, nosso objetivo é discorrer sobre o humor na obra de Jorge Amado, considerando-o, como se disse, meio de atuação política.

Tomemos algumas comparações que Bakhtin (2010, p.2) estabelece entre Rabelais e o humor. Resumidamente, diz Bakhtin sobre Rabelais: 1. é ligado profundamente às fontes populares; 2. é também o popular que explica o caráter não literário de Rabelais, isto é, sua resistência a ajustar-se aos cânones e regras da arte literária vigente no século XVI até nossos dias; e que 3. a única maneira de decifrar seu enigma é empreender em profundidade um estudo das fontes populares.

Jorge Amado também foi ligado profundamente às 
fontes populares. Sabemos que a elaboração estética não exige vivência por parte do autor. Mas no caso de Jorge Amado a vivência existiu e foi constante com o povo, principalmente a partir de sua ligação com o candomblé, tornando-se Oga a antes dos 18 anos e posteriormente Obá ${ }^{4}$ no terreiro de Ilê Opô Afonjá em Salvador. A leitura de alguns críticos, como a própria Goldstein, desconsidera essa aproximação com o povo como fundamental em sua obra. A grosso modo, a conclusão é que Jorge Amado se apropria dos elementos populares para compor suas tramas, mais por eles é influenciado. Não pretendemos dar resposta à questão neste curto espaço. Mas sugerir que sua aproximação do candomblé como participante efetivo, e das fontes populares em geral, foi tal que enformaram sua produção artística ${ }^{5}$. Tomemos a palavra do autor:

3 Título de título hierárquico no sistema do candomblé. O Ogã já é chamado de pai. Ela não recebe orixá, ou seja, não entra em transe. Possui atribuições que vão desde a música à organização do terreiro em dias de festas. Pode ser também um protetor do candomblé, uma pessoa bem relacionada que estabelece ligações políticas que favoreçam a casa de culto. E ainda pode ter cargos de importância dentro da casa como o Ogã de faca, aquele que corta, faz os sacrifícios para o orixá.

4 É uma corte de 12 ministros do orixá Xangô, que existia em Oyó, terra do orixá, e foi reinstituída no terreiro do Ilê Opô Afonjá em Salvador. São amigos e protetores do terreiro que recebem esse título honorífico. Foi instituído pela Iyalorixá Aninha em 1936. São seis Obás da direita e seis Obás da esquerda. Cada um tem seus suplentes da direita e da esquerda, o Otun e o Ossi, respectivamente.

5 É o viés que orienta a Dissertação de Mestrado do africano Komoe Gas- 
Pálida seria a descrição de uma festa de candomblé se o conhecimento do artista fosse só de observação, mesmo que de larga e aguda observação, se não houvesse entre o criador e a criação um anel de sangue, aliança de noivado e casamento, esse bater de coração em uníssono [...] se posso falar de tudo isso sem mentir, nem degradar, é porque tudo isso é parte da minha vida, de meu ser, de minha própria verdade. (SANTOS, 1993, p.86)

Mas o fato é que não se podem negar as fontes populares presentes na obra de Jorge Amado e são justamente elas, como em Rabelais, que explicam o caráter não literário da sua obra. A obra de Jorge Amado é acusada sucintamente falando- de não ter trabalho estético, literariedade ${ }^{6}$. Nos idos ton Yao (1996), ao perceber relações da literatura de Jorge Amado com os fundamentos da religiosidade africana. É o que parece sugerir Antonio Candido: "À maneira dos primitivos, o Sr. Jorge Amado é concreto. Seus personagens se apoiam sempre no dado externo e fazem um só coro com as coisas" (apud Goldstein, 2003, p.242). Ainda falta essa pesquisa, mas é provável que um estudo de sua obra a partir da teoria autobiográfica confirmasse sua ligação estreita com o candomblé e as fontes populares em geral.

$6 \mathrm{O}$ momento histórico cultural em que estão inseridas as histórias literárias dos anos sessenta/setenta, últimos momentos da modernidade, segundo Silviano Santiago, privilegia os aspectos estéticos do texto sobre 
de 40, Roger Bastide já desenvolvia estudos sobre a obra do autor que enveredaram para a seguinte conclusão: a obra de Jorge Amado não pode ser julgada pelos valores da dita literatura canônica que se pautam pela elaboração estética de base intrínseca, pois a base da literatura amadiana é a literatura oral, a literatura popular e através de seus valores e estética deve ser criticada. É nesse sentido que podemos entender a obra de Jorge Amado como "não-literária” e, como em Rabelais, resistente aos cânones vigentes. Daí sua análise, como fez Bastide, pela compreensão das fontes populares. O humor é uma das características mais importantes das fontes populares. Tratemos então, especificamente, sobre o humor em sua subversão dos valores dominantes.

\section{Diz Bakhtin (2010):}

[...] todas as formas e símbolos da linguagem carnavalesca estão impregnados do lirismo da alternância e da renovação, da consciência da

todos os outros. É o momento de exacerbamento das teorias formais, que tomam como categoria de análise e de avaliação a literariedade. $\mathrm{O}$ valor, o julgamento positivo estabelece-se pelo refinamento dos materiais - a linguagem, a reflexão sobre a mesma, a metalinguagem, a paródia. $\mathrm{O}$ fazer literário e sua representação tomam como vetor a maior ou menor aproximação com o tripé europeu Joyce-Proust-Kafka. O paradigma do literário, tomado como universal para a produção do Ocidente, deixa de lado o quadro de referências que pudesse identificar a literatura com seu momento histórico-cultural (ALVES, 2001). 
alegre relatividade das verdades e das autoridades no poder. Ela caracteriza-se, principalmente, pela lógica original das coisas "ao avesso", "ao contrário", das permutações constantes do alto e do baixo, da face e do traseiro, e pelas diversas formas de paródias, travestis, degradações, profanações, coroamentos, e destronamentos bufões).

(BAKHTIN, p. 9-10)

A carnavalização dá atenção às formas que se opõem aos valores dominantes e que, ao se oporem, provocam uma inversão dos valores estabelecidos. Esta inversão e renovação, em sua ambiguidade, está nos primórdios do carnaval já nos tempos gregos, como nos informa Macedo (1997, p.93) citando Pierre Grimal:

De fato, em sua própria etimologia, "comédia" significa "canto do kômos", isto é, o cortejo barulhento, cujos participantes, sobretudo na estação das vindimas, percorriam as aldeias cantando e dirigindo a todos os que fossem encontrados pela frente gracejos licenciosos. $\mathrm{Na}$ festa dionisíaca, os participantes disfar- 
çavam-se de animais ou desfilavam sobre os mesmos, num ritual festivo importante para o estabelecimento dos primórdios do carnaval. Por isso, nos festivais dramáticos gregos, os autores das comédias eram também autores de cantos fálicos, e a comédia, segundo Pierre Grimal, guardava em si os vestígios de uma festa do caos e o prelúdio de uma reposição da ordem.

Se o carnaval é a época da liberdade, a segunda vida do povo; o riso, sua mais representativa manifestação, é poder contra toda forma de autoridade (BAKHTIN, 2010, p.7). Ele inverte as relações hierárquicas e, portanto, investe no confronto com os mecanismos do poder. Se, como dissemos no início, a arte (neste caso, a arte que utiliza humor) não cria um novo poder que se sobrepõe ao já existente, ele, no entanto, o indaga, por vezes o rebaixa ridicularizando-o e forçando-o a uma revisão. A ordem estabelecida não pode ter continuidade sem esse constante ato revisionista que se quer amoral justamente como forma de manutenção de sua liberdade de atuar. Ainda Bakhtin:

O riso e a visão carnavalesca do mundo, que estão na base do grotesco, destroem a seriedade unilateral e 
as pretensões de significado incondicional e intemporal e liberam a consciência, o pensamento e a imaginação humana, que ficam assim disponíveis para o desenvolvimento de novas possibilidades (Ibidem, p.43).

A destruição da seriedade unilateral e as pretensões de significado intemporal são alguns dos assuntos que são tratados em O nome da rosa (1980) de Umberto Eco. O riso impediria o julgo da autoridade religiosa. Como nos informa Góes (2009, p.216), Jorge de Burgos, personagem do romance, acentua o perigo do riso. Ele, o personagem, defende que o riso não deve ser livremente permitido visto poder ser usado para desacreditar a própria Igreja, ou seja, "o riso mata o temor e isso, por sua vez, impede a fé".

Assim, a escrita carnavalizada de Jorge Amado, o riso com sua força subversiva, depõe contra os valores dominantes. É o que ocorre na narrativa de Gabriela, cravo e canela, cujo tom é satírico, mordaz e principalmente irônico. Utilizase constantemente dois elementos carnavalizantes estudados por Bakhtin: as grosserias e o baixo corporal. É através dos xingamentos, da utilização de palavras de baixo calão, que as grosserias assumem a função de degradar e regenerar, portanto, possuem um caráter ambivalente. A atenção ao baixo corporal tem a mesma função. O princípio é o rebaixamento, isto é, "a transferência ao plano material e corporal, o da terra 
e do corpo em sua indissolúvel unidade, de tudo que é elevado, espiritual, ideal e abstrato" (BAKHTIN, 2010, p.17).

Tiêta do agreste (1977), Gabriela, cravo e canela, Dona flor e seus dois maridos, Tenda dos milagres (1969), são narrativas cheias de grosserias e erotismo, voltando-se ao baixo corporal. Lembremos que o erotismo, o sexo, é um dos elementos do baixo corporal mais utilizado como forma de oposição aos valores dominantes, como citamos acima. Almeida (1986, p.80) relaciona o erotismo com a ânsia de liberdade anárquica de que já falamos. Para o autor: “[...] o erotismo adquire um saudável sentido de libertação. Tanto mais que, na sociedade burguesa, a repressão sempre se voltou com particular ferocidade contra o sexo e o instinto". E mais adiante diz: "uma verdadeira bandeira de insubmissão do indivíduo ao meio" (Ibidem, p.83).

O baixo corporal se manifesta no corpo. O corpo é que recebe os afluxos dos xingamentos. Lembremos que o corpo é demonizado na Idade Média junto com o paganismo dos povos não cristãos. Jaques Legoff (BREMMER; ROODENBURG, p. 73) nos informa que na Idade Média Gregório, o Grande, define o corpo como a "abominável vestimenta da alma". Havia, em suma, uma tendência a vê-lo como pernicioso, instrumento do demônio.

Daí o riso e o corpo serem elementos renovadores em personagens como Gabriela, Tiêta, Dona Flor, Vadinho: "O corpo representa e encarna todo universo material e corporal, concebido como inferior absoluto, como princípio que 
absorve e dá a luz, como um sepulcro e um seio corporais, como um campo semeado que começa a brotar" (BAKHTIN, 2010, p.24).

Grosserias, erotismo, corpo, liberdade, carnaval, compõem a segunda vida do povo. Só o povo, na leitura de Bakhtin (Ibidem, p.17), poderia ser veículo dessa inversão proposta pela carnavalização.

O porta-voz do princípio materialcorporal (princípio da festa, do banquete, da alegria, da festança) não é nem o ser biológico isolado, nem o egoísta indivíduo burguês, mas o povo, que na sua evolução cresce e se renova constantemente.

Os mantenedores da ordem se condenam a uma vida sem riso, ou de um riso controlado pelos limites da boa apresentação pública como o riso do político. Os poderes dominantes jogam com os valores e padrões que mantém uma sociedade sob força da coercitividade. Este poder visa à intemporalidade, ou dela se veste. Como se veste da seriedade, da imponência, da defesa dos "princípios tradicionais da moralidade e bons costumes". O embate se dá na praça pública, no lugar onde os jogos se dão e onde os valores são disputados. As classes dominadas são o veículo dessa inversão carnavalesca. 


\section{Considerações Finais}

O efeito carnavalizador irrompe com a ordem estabelecida tendo o elemento popular como principal canalizador dessa reversão que a carnavalização produz. Uma fatura desse povo se sobressai em meio às condições adversas. É a fatura que se autonomiza, que se inscreve no meio social com sua força anárquica e satírica. Esse povo é, principalmente, o povo representado por Jorge Amado. Fruto de uma atitude anárquica fundamental de base romântica, pois que revolucionária, e de uma veia humorística subversiva, utilizando seus próprios elementos culturais populares em uma complexa e ambivalente inversão carnavalizante dos valores dominantes.

\section{Referências}

ALMEIDA, José Maurício Gomes de. Algumas considerações sobre a ideologia nos romances de Jorge Amado. In: Estudos de Literatura Brasileira, Faculdade de Letras / UFRJ, v.2, n.1, p.71-87, 1986.

ALVES, Ivia. De paradigmas, cânones e avaliações - ou dos valores negativos da produção literária de Jorge Amado. Letras de Hoje. Porto Alegre, v. 37, n. 2, p.197-208, jun., 2001.

AMADO, Jorge. Gabriela cravo e canela: crônica de uma cidade do interior. São Paulo: Martins Editora, s/d. 
. Tenda dos milagres. São Paulo: Martins Editora, s/d.

BAKHTIN, Mikhail. A cultura popular na Idade Média: o contexto de François Rabelais. Trad. De Yara Frateschi Vieira. São Paulo: Hucitec, 2010.

BOSI, Alfredo. História concisa da literatura brasileira. São Paulo: Cultrix, 2006.

GALVÃO, Walnice Nogueira. Saco de gatos: ensaios críticos. São Paulo: Livraria Duas Cidades, 1976.

GÓES, Paulo de. O problema do riso em O nome da rosa, de Umberto Eco. Revista Filosofia. Curitiba: Aurora, v.21, n. 28, p.213-240, 2009.

GOLDSTEIN, ILana Seltzer. O Brasil best seller de Jorge Amado: literatura e identidade nacional. São Paulo: SENAC Editora, 2003.

LE GOFF, J. O riso na Idade Média. In: BREMMER, J.; ROODENBURG, H. (Org.). Uma história cultural do humor. Rio de Janeiro: Record, 2000, p.64-82. MACEDO, José Rivair. Riso ritual, cultos pagãos e moral cristã na alta Idade Média. Boletim do CPA, Campinas, n.4, p. 87-111, 1997. 
MARX, K; ENGELS, F. Manifesto do partido comunista. Trad. Sueli Tomazine Barros Cassal. Porto Alegre: L\&PM, 2010.

SANTOS, Itazil Benício dos. Jorge Amado: Retrato incompleto. Rio de Janeiro: Record, 1993.

SWARNAKAR, Sudha. The fallen woman in twentiethcentury English and Brazilian novels: a comparative analyses of D. H. Lawrence and Jorge Amado. 1998. 371f. Thesis (Doctor of Philosophy) - Centre for British and Comparative Cultural Studies. UNIVERSITY OF WARWICK.

THOMPSON, E. P. Os românticos: a Inglaterra na era revolucionária.Trad. Sérgio Moares Rêgo Reis. Rio de Janeiro: Civilização Brasileira, 2002.

YAO, Komoe Gastón. Brasil e África em textos de Jorge Amado: convergências reais ou simbólicas de valores negro-africanos e afro-brasileiros. 1996. 134f. Dissertação (Mestrado em Letras) - Faculdade de Filosofia, Letras e Ciências Humanas da Universidade de São Paulo, São Paulo. (Mimeo). 


\section{Será um romance proletário?}

Geralda Medeiros Nóbrega

\section{Resumo}

Este artigo se apresenta como um recurso para destacar a trajetória de Jorge Amado enquanto escritor, voltado para narrar a vida dos que estão à margem, excluídos do progresso e das condições de vida digna, como está em Cacau, romance publicado em 1933. Em nota do escritor, ele explicita: "Tentei contar neste livro, com um mínimo de literatura para um máximo de honestidade, a vida dos trabalhadores das fazendas de cacau do sul da Bahia". O romance, espécie de autobiografia ficcionalizada, apresenta um narrador consciente de sua função na trama da história, qual seja, a sua fidelidade aos companheiros que vivenciam a miséria e os mais variados tipos de carência, inclusive de cidadania. A vida daquelas pessoas, delineada ao longo da narrativa, dá consistência ao romance, em que a denúncia das injustiças é o percurso trilhado pelo autor-narrador, que apresenta o desfecho: "Eu partia para a luta de coração limpo e feliz".

Palavras-chave: Consciência de classe. Escrita de si. Proletariado. 


\section{Introdução}

A obra Cacau, publicada em 1933, é apresentada pelo próprio autor, Jorge Amado, que no início do seu texto, informa: "Tentei contar neste livro, com um mínimo de literatura para uma máximo de honestidade, a vida dos trabalhadores das fazendas de cacau do sul da Bahia" (p.8).

O autor ainda pergunta: "Será um romance proletário"? Esta pergunta que o autor faz sugeriu-me o título deste artigo, que procurarei, ao longo de minha narrativa, responder a esta pergunta, ao mesmo tempo que me deterei na visão de mundo do autor e tentarei fazer uma apreciação crítica da realidade por ele trabalhada. A exemplo de Ianni (1992) me empenho em compreender o presente em suas raízes próximas e distantes porque, em diferentes épocas o pensamento social debruça-se também sobre o passado, na tentativa de compreender o presente. E vemos que nunca vamos debelar as injustiças praticadas contra os que estão à margem do progresso, contra os pobres, contra os oprimidos e contra aqueles que não tiveram condições de atingir os parâmetros de uma vida digna. É isto que, de princípio, detectamos no romance Cacau. Procurarei trabalhar numa perspectiva de uma sociologia da literatura, quando me deterei na análise da visão de mundo do autor, a partir da qual se torna possível a interpretação dos diferentes elementos da narrativa, alicerçada na ideia segundo a qual podemos chegar a uma interpretação mais ampla, ideia que terá por base o alicerce semiótico que possibilitará apreender os sentidos que organizam o texto 
desdobrável em semioses diversificadas. Seguindo os passos de Goldmann (1972, p.20) acreditamos que "uma obra literária não tem sentido que não seja fundamentado, numa montagem específica do campo dos possíveis [...]". Goldmann associa este campo a uma opção antropológica, que esclarece o texto literário, abrindo novas perspectivas ao estudo sociológico da obra.

Daí se chegar a um consenso quando dizemos que o sociologicamente significativo exprime uma certa realidade de uma determinada época. Encontra-se no romance Cacau a estrutura mental da classe dominada. O escritor testemunha a sua fascinação pela cultura popular e manipula personagens do meio popular, produtos de sua imaginação, das quais o mundo real, de princípio, não poderá comportar, uma vez que o universo romanesco não abre espaço para a continuidade de suas vivências.

Quero situar este romance no âmbito de uma cultura de resistência, em que o autor modela o seu narrador, aqui visto e trabalhado como um ser de linguagem, que eu vejo como "imagem de vida". É um narrador de primeira pessoa, que é forjado para estabelecer a visão crítica da realidade, ao mesmo tempo que denuncia todas as situações de antivida, a começar pela reificação do ser humano. O protagonista está preparado para desenvolver a ideologia do autor que se instala através de um viés dialético, que se enquadra no pensamento de Jameson (1985, p.315), quando assegura que: "cabe pois à crítica literária continuar comparando o interior e o exterior, a 
existência e a história, persistir em passar julgamento sobre a qualidade abstrata da vida no presente e manter viva a ideia de um futuro concreto. Possa ela mostrar-se à altura da tarefa".

A obra Cacau se adequa a esta visão, quando a relacionamos com a função crítica literária, pela interação do contexto que acopla a forma e conteúdo, de que posteriormente falarei. O protagonista, que é conhecido como Sergipano, vive os fatos organizados, num romance memorialista, que aqui caracterizo como memória ficcionalizada. Com base em Antonio Candido (1987) destaco personagens outras, pois quando pensamos nelas, pensamos na vida que viveram, nos problemas em que se enredaram, na linha de suas vivências, traçada conforme uma certa duração temporal, referida a determinadas condições de ambiente.

O sergipano começa narrando a sua vida em Ilhéus, na Fazenda Fraternidade, do coronel Manuel Misael de Sousa Teles, que os trabalhadores apelidaram de Mané Frajelo e Mané Miserável Saqueia Tudo. Este é, pois, o tema desenvolvido no primeiro capítulo.

No segundo capítulo, que o narrador denomina de Infância, ele explicita:

Pouco me recordo de meu pai. Ficamos muito crianças eu e minha irmã, ela com três, eu com cinco anos, quando ele morreu. Lembrome apenas que minha mãe soluçava, os cabelos caídos sobre o rosto páli- 
do, e que meu tio, vestido de preto, abraçava os presentes com uma cara hipócrita de tristeza. [...] Papai, quando vinha da fábrica me fazia sentar sobre os seus joelhos e me ensinava o ABC com sua bela voz. Era delicado e incapaz, como diziam, de fazer mal a uma formiga. Brincava com mamãe como se ainda fossem namorados. Mamãe muito alta e muito pálida, as mãos muito finas e muito longas, era de uma beleza esquisita, quase uma figura de romance.

(AMADO, 1980, p.14)

As lembranças, armazenadas pela memória, vêm à tona através da percepção sensitiva, transmitida através de sensações auditiva, visual e tátil, o que, segundo o pensamento de Agostinho (1986, p.258): “A memória armazena tudo isso nos seus amplos recessos e em seus esconderijos secretos e inacessíveis, para ser reencontrado e chamado no momento oportuno", o que será trabalhado pelo narrador em toda a obra.

A persona destaca que o seu tio, que era sócio de seu pai, rouba-lhes tudo e ele vai trabalhar na fábrica como operário até que, há um desentendimento entre eles que o obriga a procurar trabalho fora, indo parar numa fazenda de cacau 
em Ilhéus. Na sequência da narrativa, o narrador se detém em sua nova vida e registra tudo que ouve ou observa. Associa a descrição à narrativa e a linguagem, ora visual, ora auditiva, moldava o seu pensamento, destacando os companheiros com quem tinha maior afinidade.

O narrador é treinado para desenvolver uma visão crítica que, de princípio, não ultrapassa a fase embrionária. É o herói, classificado por Lukács de herói problemático, porque não consegue superar os entraves que o mundo apresenta em relação a si mesmo e em relação aos outros. Passa o romance a ser "a forma representativa da época, na medida em que as categorias estruturais do romance coincidem constitutivamente com a situação do mundo" (LUKÁCS, 2000, p.96).

Este romance que se apresenta como denúncia de situações de antivida, vivenciadas pelos trabalhadores das fazendas de Cacau, tem, em Jorge Amado, um arauto na defesa dos interesses da classe trabalhadora, explorada e vilipendiada. $\mathrm{O}$ autor, fazendo uso de um imaginário cultural, associado a um imaginário linguístico, apresenta-nos um imaginário agrário que serve de esteio para conectar as variadas situações de desrespeito ao ser humano, na exploração do homem pelo homem:

"Ninguém reclamava. Tudo estava certo. A gente vivia quase fora do mundo e a nossa miséria não interessava a ninguém. A gente ia vivendo por viver. Só muito de longe surgia a ideia de que um dia aquilo poderia mudar. Como, não sabíamos." (AMADO, 1980, p.47). 
O herói, gradativamente, vai adquirindo consciência de que existe uma relação entre o mundo e as pessoas que nele estão, esta consciência é explicitada em nome de todos: "Mais animais do que homens [...]. Eu, naquele tempo, como os outros trabalhadores, nada sabia das lutas de classe. Mas adivinhávamos qualquer coisa" (AMADO, p.48). Goldmann (1976) discute o herói problemático e lembra que o romance de herói problemático está ligado estética e artisticamente às novas formas de consciência coletiva. Assim, para este estudioso, "o homem só seria autêntico na medida em que se considere ou sinta como parte de um conjunto em devir, e se situe numa dimensão transindividual histórica ou transcendente" (GOLDMANN, 1976, p.26).

Bosi (1999), seguindo as pegadas de Lukács (2000) e Goldmann (1976), faz uma adaptação da posição destes dois estudiosos e apresenta uma hipótese de trabalho, aplicada ao romance brasileiro de 1930 para cá e fala da tensão que se apresenta como relacionamento do autor com o mundo objetivo de que depende e com o mundo estético que lhe é dado construir (BOSI, 1999, p 390-395). Distribuindo o grau de tensão entre o herói e o seu mundo, Bosi apresenta quatro níveis de tensão, assim distribuídos: a) romance de tensão mínima; b) romance de tensão crítica; c) romance de tensão interiorizada e d) romance de tensão transfigurada. Bosi coloca os romances de Jorge Amado na categoria de tensão mínima, mas neste romance Cacau eu discordo, e o situo em nível do romance de tensão crítica, uma vez que Jorge 
Amado recoloca o homem na sua posição do grupo social e diante de si mesmo bem nos moldes de Goldmann (1976). Este romance Cacau (1980) é multifacetado: em sendo uma obra de memória, há nele ainda uma atuação em torno da escrita de si. Romance em que predomina uma visão crítica da realidade, que resulta numa literatura de resistência em que coloca Amado como um escritor progressista que enfoca o povo, (visto aqui como a não elite), em situação privilegiada em busca dos "valores autênticos", de que fala Lukács (2000) reforçado por Goldmann (1976). É também um romance de contestação e de denúncia e ainda aponta caminhos que salvaguardam os valores que devem ser cultuados e "É nesse sentido que se pode dizer que a narrativa descobre a vida verdadeira, e que esta abraça e transcende a vida real. A literatura, com ser ficção, resiste à mentira. É nesse horizonte considerado em geral como o lugar da fantasia, pode ser o lugar da verdade mais exigente." (BOSI, 2002, p. 135).

Logo, a linha do imaginário aponta para uma literatura, que consegue ser comprometida com os efeitos de vários imaginários, como o imaginário nacional, o que segundo Brandão (2005) se manifesta como indagação, preservando a sua natureza difusa que se esbate num imaginário tradicional (representativo de forma de exploração institucionalizada), imaginário histórico (representativo da época), imaginário teórico (que remete para a reação provocada em termos de análise), imaginário linguístico (forma socialmente agregadora) e imaginário literário (saber gerado pela literatura). É 
o que Brandão (2005, p.12) afirma em relação a outros autores: "a ficção irrealiza a realidade nacional e, simultaneamente, realiza o imaginário nacional".

O imaginário nacional atua, nesta obra de Jorge Amado, como representação da realidade social, em que as pessoas e, principalmente, os pobres não tinham direito a nada, mormente os trabalhadores rurais. Eis como o narrador registra a miséria:

- Você veio do Ceará logo agora que foi uma dinheirama pra lá... Os jornais deram. Eu li: $O$ governo garantia que não havia de morrer fragelado.

- Só Deus sabe. Ele come o dinheiro. Minha muié morreu pelo caminho e minha fia ficou na rua dos "Sete pecados mortais".

- Que rua é essa?

- É a rua destas... - e apontava a rameira.

(AMADO, p. 38)

E, diante do imaginário linguístico, recorrente na linguagem do povo, que remete para uma forma que agregava na década de trinta a grande massa da população brasileira, nos deparamos com a coerência do escritor, na representação de suas personagens.

O narrador elege a memória como mentora de 
suas lembranças e apresenta os companheiros com quem vai conviver mais intimamente: "Morávamos quatro na casinha. Honório, gigantesco, os dentes brancos sempre a rirem na boca negra; Colodino, carpina, que estava construindo barcacas para o coronel, e João Grilo, mulato magro, que sabia anedotas". (AMADO, p. 42).

Às vezes, reunidos, os amigos questionavam a situação de miséria em que viviam e pensavam em como sair dela. «Mais animais do que homens, tínhamos um vocabulário reduzidíssimo onde os palavrões imperavam.” (AMADO, p.48).

Acredito, seguindo a orientação de Jameson (1985) que a obra e o contexto interagem dialeticamente e isso é uma constante nas obras de Jorge Amado. Sei também, seguindo a orientação de Goldmann (1973) que a personagem não tem existência fora do texto, uma vez que é um ser criado pela linguagem. É preciso, pois, compreender a obra, para ressaltar a sua significação e situá-la no contexto sociopolítico e cultural para poder explicar a amplitude e cultural para poder explicar a sua amplitude no que concerne aos motivos que a fizeram vigir, pois trata-se com efeito da significação literária que a obra assume. Em Cacau, as personagens não tomam consciência da situação, é o narrador (neste contexto, o sergipano) que assume a consciência coletiva. $\mathrm{O}$ autor encaminha o seu narrador para atingir o seu objetivo, no sentido do desenvolvimento de uma literatura comprometida com a vida, comprovando que "o fatalismo não é senão a maneira pela qual os fracos se revestem de uma vontade ativa e real." (GRAMSCI, 1978, p. 24). 
É necessário, pois, ter conhecimento do que seja consciência de classe, para depois encetar o processo de luta de classe, que é um processo lento. No romance Cacau, esta consciência vai se delineando de modo lento, e o narrador vai descrevendo gradativamente as situações e pessoas, envolvidas no contexto, como já referenciei antes: " $\mathrm{Eu}$, naquele tempo, como os outros trabalhadores, nada sabia das lutas de classes. Mas adivinhávamos qualquer coisa" (AMADO, p. 48).

Há todo um processo de solidariedade em curso que vai dando consistência à consciência de classe, como o posicionamento do narrador em relação às prostitutas:

Pobres mulheres, que choravam, rezavam e se embriagavam na Rua da Lama. Pobres operárias do sexo. Quando chegará o dia da vossa libertação? O narrador continua: Eu fico pensando no dia em que a Rua da Lama se levantar, despedaçar as imagens dos santos, tomar conta das cozinhas ricas. Neste dia, até filhos elas poderão ter.

(AMADO, p.65)

Quando a família do coronel vem para a fazenda, é costume escolher um dos trabalhadores para acompanhar Mária, a filha do fazendeiro. A escolha recaiu sobre o sergipano, que se sente humilhado. Um dia foi chamado de ama- 
seca, por um dos companheiros e negou-se a denunciá-lo, o que provoca em Mária o comentário: “- Não trai os outros, não é? Vocês todos não valem o que comem.” (AMADO, p.94).

O filho do coronel chega à fazenda e começa a assediar Magnólia, a namorada de Colodino, que é pega traindo o namorado. A cara de Osório, o coronelzinho, foi cortada, com um grande talho. "Colodino surrava-o com o facão. $\mathrm{O}$ sangue corria. [...] Magnólia, de camisa, num canto, era Maria Madalena toda debulhada em lágrimas. Colodino cuspiu: Puta" (AMADO, p. 117).

O sergipano é escalado para ir buscar um médico para Osório e Honório foi contratado para matar Colodino. Observa-se, aí, o gérmen da consciência de classe, pois Honório fica ao lado do companheiro, perdendo "quinhentão". Colodino abraça a todos e promete ao sergipano que escreverá para ele, do Rio. "Honório partiu com a repetição para a tocaia. Colodino apertou-o nos braços longamente." (AMADO, p.120).

Honório diz aos amigos que gostava de Colodino, mas não o matou porque ele era alugado como eles. "Matá coroné é bom, mas trabaiadô não mato. Não sou traído." (AMADO, p.121). O narrador posteriormente conclui que o gesto de Honório não era generosidade, mas tinha um nome bonito: "Consciência de Classe".

A família do coronel volta para Ilhéus. Osório restabelecera-se e antes de viajarem houve festas em que Mária recitou Castro Alves e o poeta, amigo de Osório, fez um dis- 
curso sobre analfabetismo, o que deu a ideia ao narrador de reunir cartas de trabalhadores e rameiras para publicar um dia. Assim nasceu Cacau. As cartas eu caracterizo como escritas de si, no sentido trabalhado por Gomes (2004, p.19) em que:

[...] a escrita de si é uma forma de produção de memória que merece ser guardada e lembrada, no caso de correspondência, o encarregado dos procedimentos de manutenção e arquivamento dos documentos é o "outro", é o outro a quem se destina a carta e que passa a ser seu proprietário. [...] Escrever cartas exige tempo, disciplina, reflexão e confiança. Há sempre uma razão ou razões para fazê-lo: informar, pedir, agradecer, desabafar, rememorar, consolar, estimular, comemorar etc. A escrita de si e também a escrita epistolar podem ser (e são com frequência) entendidas como um ato terapêutico, catártico, para quem escreve e para quem lê. (Grifo do autor).

$\mathrm{E}$ as cartas que o narrador tem em mãos apresentam este teor. Acrescente-se a estas características o caráter utilitário que as cartas representaram para o narrador, o que resul- 
tou na publicação do livro Cacau. Esta técnica utilizada por Jorge Amado é o mérito de um escritor que, utilizando várias formas de imaginário a que fiz referência alhures, nos brinda com uma literatura representativa de um compromisso com os injustiçados ao mesmo tempo que aponta caminhos para a resistência e a efetiva responsabilidade que o fazer literário pode desenvolver.

O narrador lembra que o livro está sem seguimento, o que quer dizer que o romance não possui uma linearidade. O Sergipano tornou-se amigo de Mária que queria torná-lo capataz. Quando o cacau começou a cair, baixaram os salários para três mil-réis, em que Sergipano chefiou uma revolta, decidindo que não voltariam às roças, mas o plano não vigorou, pois João Grilo informou:

- Nem pense... Chegou trezentos e tantos flagelados que trabalha por qualquer dinheiro... e a gente morre de fome.

- Estamos vencidos antes de começarmos a luta.

- Nós já nasce vencido... - sentenciou Valentim.

(AMADO, p.131)

A família do coronel retorna à fazenda e Mária volta noiva do amigo de seu irmão. Ela quis falar com Sergipano para declarar o seu amor, certificando-se de que também é amada e afirma categórica: 
- Faremos o irremediável. Papai subirá às nuvens mas, não tem jeito. Se conformará. Lhe dará uma roça, você será patrão.

- [...] Não, Mária, continuo trabalhando. Se você quiser ser mulher de alugado... Fez um muxoxo e levantouse. Eu fiquei sentado.

(AMADO, p.135)

Por coincidência, neste mesmo dia chegou outra carta de Colodino, que tornava a falar em luta de classe. Sergipano é chamado para ir para o Rio. Acertou suas contas e retirou cento e oitenta mil-réis, saldo de dois anos e decide ir embora.

Jorge Amado encaminha tudo para um desfecho já esperado. O herói resiste a tudo, renuncia a tudo para ser fiel a um projeto pré-estabelecido pelo autor. A luta de classe, decorrente da consciência de classe comprova que o autor é socialista, por isto defende a consciência de classe.

Jameson (2002, p.326) destaca:

Do meu ponto de vista, o método através do qual uma sociologização saudável do cultural e do conceitual pode escapar de se desintegrar nos mais obscenos pluralismos consumistas do capitalismo tardio passa pela mesma estratégia filosófica adotada 
por Lukács para o desenvolvimento de uma análise ideológica de classe a saber: generalizar suas análises das ligações construtivas entre o pensamento e o ponto de vista de classe ou do grupo, respectivamente, e projetar uma teoria filosófica totalmente desenvolvida do ponto de vista em que a produção gerativa ou ponto de transferência entre conceituação e experiência coletiva é posta em destaque.

Cacau, nos diz o narrador:

Não é um livro bonito, de fraseado, sem repetição de palavras. É verdade que eu hoje sou operário, tipógrafo, leio muito, aprendi alguma coisa. Mas, assim mesmo, o meu vocabulário continua reduzido e os meus camaradas de serviço me chamam de Sergipano, apesar de eu me chamar de José Cordeiro.

(AMADO, p. 123-124)

Entre o amor por Mária e o amor pela sua classe, o herói assim se expressa: "O amor pela minha classe, pelos trabalhadores e operários, amor humano e grande, mataria 
o amor mesquinho pela filha do patrão. Eu pensava assim e com razão.” (AMADO, p.137).

O narrador encerra afirmando que partia para a luta de coração limpo e feliz e eu encerro esta narrativa dizendo que estamos de fato diante de um romance proletário em que o tema central é a luta de classe e, assim, Jorge Amado cumpre a função precípua de um escritor socialista.

\section{Referências}

AGOSTINHO, S. Confissões. São Paulo: Paulinas, 1984.

AMADO, J. Cacau. 34. ed. Rio de Janeiro: Record, 1980.

BOSI, A. História concisa da literatura brasileira. 3. ed. São Paulo: Cultrix, 1999.

. Literatura e resistência. São Paulo: Companhia das Letras, 2002.

BRANDÃO, L. A. Grafias da identidade: literatura contemporânea e imaginário nacional. Rio de Janeiro/Belo Horizonte: Luparina/Fale, 2005.

CANDIDO, A. et al. A personagem de ficção. São Paulo: Perspectiva, 1987. 
GOLDMANN, L. A sociologia do romance. Rio de Janeiro: Paz e Terra, 1976.

- Crítica e dogmatismo na cultura moderna. Rio de Janeiro: Paz e Terra, 1973.

GOLDMANN, L.; BONHÔTE, N.; LEENHARDT, J.; ELSBERG, J. Sociologia da literatura. Lisboa: Estampa, 1972.

GOMES, A. C. Escrita de si, escrita da história. Rio de Janeiro: FGV, 2004.

GRAMSCI, A. Concepção dialética da história. 2. ed. Rio de Janeiro: Civilização Brasileira, 1978.

IANNI, O. A ideia de Brasil moderno. São Paulo: Brasiliense, 1992.

JAMESON, F. Marxismo e forma: teorias dialéticas da literatura do século XX. São Paulo: HUCITEC, 1985.

Pós-modernismo: a lógica cultural do capitalismo tardio. 2. ed. São Paulo: Ática, 2002.

LUKÁCS, G. A teoria do romance. São Paulo: Duas Cidades: Ed. 34, 2000. 


\section{Fntre Bahias e IMusseques: \\ O Diálogo Além IMar de Jorge Amado \\ e Luandino Vieira}

Lilian Barbosa

Sueli Meira Liebig

\section{Resumo}

Os escritores Jorge Amado e José Luandino Vieira possuem, em comum, além de uma escrita que promove a visualização da realidade social de sua cultura e região, uma estreita relação de escrita, sendo o segundo apreciador do primeiro e tendo-o como uma espécie de protótipo. Entretanto, o conceito prototípico aqui não quer significar cópia ou imitação, mas antes um estilo de escrita que vincula os dois escritores dentro de um modelo produtor literário que visa ao esclarecimento e, ao mesmo tempo, ao deleite do leitor; um realismo formal proporcionador de um espaço de resistência via escritura. Dentro desta perspectiva, nosso intuito será o de aproximar os dois escritores em questão demonstrando como que a escrita de Amado e Luandino, respectivamente em Capitães de Areia e A Cidade e a Infância, dialogam e convergem entre si. O recorte analítico será feito entre o último conto do livro do escritor angolano e algumas passagens do romance do escritor brasileiro para demonstrar como, à luz da literatura comparada, o texto angolano nasce da leitura do brasileiro. Tendo como escopo a questão do dialogismo bakh- 
tiniano, proporemos a filiação temática, engajada e literária dos dois escritores em questão e demonstraremos, por meio de nossas análises em que medida tais semelhanças (e as possíveis divergências) servem para a compreensão do todo do livro tanto de Jorge Amado quanto de Luandino Vieira.

Palavras-Chave: Literatura comparada. Capitães de Areia. A cidade e a infância. Literatura engajada.

\section{Introdução}

O baiano Jorge Amado foi, por muito tempo, o escritor brasileiro mais lido e publicado no mundo. Sintonizado com os ideais implementados pela intelligentsia soviética, Jorge Amado cumpre o papel de fazer de sua arte um agente transformador da realidade. Assim, ele expressa a escolha dos temas e formas como algo mais que mero processo literário, mas também opção actancial política. Os livros produzidos pelo escritor baiano, tal como o romance brasileiro de 1930 e o romance americano do entre guerras, reflete a crise social do período em questão sob uma perspectiva marxista, reavivando a atividade literária de ênfase social e gerando seguidores. Dessa forma, é fato que nos países de língua oficial portuguesa, a figura de Jorge Amado é extremamente relevante em relação à questão de influência e diálogos supranacionais. Tal afirmação, mais que lugar comum, é um fato a ser evidenciado, posto que as relações literárias entre os países oficiais de língua portuguesa ainda são pouco exploradas em relação à literatura se comparada aos 
trabalhos de economia, história, sociologia e antropologia.

Jorge Amado foi figura proeminente para a produção da geração portuguesa dos Neorrealistas e essencial para a Literatura Africana de língua portuguesa que surge a partir da década de cinquenta. Autores de tais países afirmam, categoricamente, terem lido e aludem constantemente ao papel seminal da ficção do autor baiano na consolidação das literaturas engajadas de Angola, Cabo Verde e Moçambique.

Eu venho de muito longe e trago aquilo que eu acredito ser uma mensagem partilhada pelos meus colegas escritores de Angola, Moçambique, Cabo Verde, Guiné Bissau e São Tomé e Príncipe. A mensagem é a seguinte: Jorge Amado foi o escritor que maior influência teve na gênese da literatura dos países africanos que falam português.

(COUTO, 2011)

Como demonstra Mia Couto, o papel de Jorge Amado é indiscutível na constituição de um sistema literário autônomo para os países africanos de língua portuguesa. Um sistema que não se erige à sombra da metrópole, mas que se constrói em diálogos além-mar com uma literatura que já foi pós-colonial e que afastou-se de seu par lusitano para alçar novas descobertas literárias. Ou seja, por uma perspectiva 
social, quando os países africanos negam a maternidade portuguesa e se aproximam do Brasil - reconhecido pelos africanos como "pai” literário - produzem uma negação que, tomadas as devidas proporções, se assemelha a um Complexo de Édipo às avessas. A visada edipiana se torna possível pela figura de Jorge Amado, expoente máximo dessa paternidade literária entre as ex-colônias.

Ao passarmos para o contexto específico de Angola, temos que grande parte da história da guerra colonial se confunde com a literatura local, sendo esta uma espécie de arma de combate para aquela. A literatura deste período é marcada por sua forte relação com a brasileira. Escritores que atualmente possuem reconhecimento oficial foram, nos idos anos do conflito, guerrilheiros e/ou prisioneiros políticos por conta de produzirem propaganda política a favor da independência provinciana e encontraram seu modelo literário e/ou leitura de ânimo nos livros saídos do Brasil.

Um exemplo de figura atualmente reconhecida na cena literária angolana e que sofreu por conta da propaganda nacionalista é Luandino Vieira. Nascido em Portugal, sua identificação com o espaço africano é tão grande que ao se tornar combatente ativo de Angola - mesmo que longe dos campos -, escolhe para si o nome de Luandino, que assinala sua identificação com a capital do país. O exame da obra de Luandino permite entrever a história da luta em prol da libertação colonial de Angola frente aos portugueses e nos fornece elementos que comprovam o relacionamento amistoso entre as letras angolanas e brasileiras. Luandino, assim como Jorge Amado, era marxista e sua relação com a litera- 
tura engajada é marca de seu projeto estético.

Em carta enviada da prisão a seu amigo Carlos Everdosa, Luandino expressa seu sentimento político e sua influência literária. Em Luanda, antes de ser transferido para o campo de concentração do Tarrafal, em Cabo Verde, escreve:

31-7-64

Meu caro:

Faltam poucas horas para embarcar no "Cuanza" rumo a cabo Verde - ou assim dizem. [...] É muito difícil nesta altura dizer qualquer coisa; mas podes afirmar aos amigos e companheiros que procurarei sempre ser digno da confiança que têm em mim; que, nas minhas possibilidades e dentro do meu particular campo de acção - o estético - ... tudo farei para que a felicidade, a paz e o progresso sejam usufruídos por todos. [...]

O meu livro, o livro da Linda afinal, chegar-te-á talvez com mais trabalhos selecionados para a $2^{\mathrm{a}}$ edição. Se a conseguirem aí em edição de bolso era óptimo para ir a concurso da Sociedade Portuguesa de Escritores. Depois enviem ao Jorge Amado (Brasil) para ver se conseguem uma edição lá. Não 
é pelo livro, claro, é pelo que ele pode representar como "arma" para a nossa libertação $[. .$.

(EVERDOSA, 1980, p.90).

Podemos notar, pelo processo de escrita, que o discurso forjado por Luandino é marcado pela utopia transgressiva. Sua atuação enquanto escritor é alicerçada em um conceito político que visa a autonomia de seu país. Esta possibilidade está marcada textualmente na carta de Luandino por meio das reticências utilizadas depois do termo "estético", ou seja, a possibilidade de transcendência de significado expressa pelas reticências pode indicar que a atuação do escritor não se limita ao signo, mas sugere que exista um envolvimento direto entre arte e ação revolucionária.

A referência de Luandino Vieira a Jorge Amado - que apresentava posições políticas progressistas muito próximas às suas - revela a importância atribuída por ele a uma edição brasileira do livro naquele momento e reforça o caráter militante e engajado assumido pela literatura, que se torna arma de combate contra o salazarismo; também importa que o retrato da crueldade imposta pela ditadura fascista sairia de seu âmbito local e atingiria o universal, promovendo, quem sabe, uma espécie de comoção ou atitude por parte de outros países; por fim, serviria ainda como mostra da resistência progressista africana frente aos ideais ditatoriais existentes. Assim, ao enviar seu livro a Jorge Amado, mais que divulgar sua literatura, Luandino pretendia

\section{2}


expandir seu campo de atuação do literário para o engajado.

A leitura dos livros do autor angolano nos mostra que, até compor Luuanda (sua obra prima), o escritor passa por um processo formativo que se inicia pelo convívio com a obra de Jorge Amado. Tal nuance pode ser vista claramente ao aproximarmo-nos da primeira publicação de Luandino Vieira, o livro de contos $A$ cidade e a Infância, editado em 1960. O livro reúne dez contos produzidos pelo escritor e que têm, como marca maior, a figura dos angolanos como personagens principais.

Dentre os dez contos, o que mais chama-nos a atenção é aquele que encerra o livro, intitulado Companheiros. Nele temos um trio de meninos angolanos e pobres que vivem nas ruas de Huambo (Nova Lisboa à época), sendo este espaço o quarto elemento da narrativa. Como já se prefigura no título do livro a questão do espaço, assim como a infância, é altamente significativo para a compreensão das narrativas. Em relação ao segundo elemento (a infância), temos três personagens que transitam entre a infância e a juventude. São meninos que, com o conhecimento aprendido nas ruas de Nova Lisboa, tornam-se adultos antes do tempo. Sujeitos que aprendem por meio da vivência com a cidade, já que "(...) a terra estava no seu corpo. As anharas extensas. A lavra do milho, da mandioca. A tentação da cidade também o tocara: não resistira ao chamado das bugingangas, dos panos coloridos da loja do sô Pinto." (VIEIRA, 2007, p.94). Aprendemos, junto com as personagens, que viver à margem em África é fundamental 
para forjar uma consciência política. Ou seja, as personagens aprendem politicamente com seus estados e, principalmente por meio do espaço em que vivem e no qual são obrigados a sobreviver.

Interessa notar que eles amadurecem juntamente com a cidade, sendo esta que direciona a vida daqueles, pois ao experienciarem as derrotas do dia-a-dia, ao invés de desistir, seguem aprendendo "[...] na noite clara da cidade jovem" (VIEIRA, 2007, p. 98). É este espaço quem, na verdade, se torna a personagem principal das pequenas narrativas. Assim, Luandino nos apresenta uma Angola menos colonial e mais humana: "ao longo do texto somos introduzidos assim num espaço social e humano angolano, específico, inserido num espaço geográfico concreto e bem determinado: Luanda e, ocasionalmente, Huambo [...]" (FERREIRA, 2007, p.119).

A cidade, como uma personagem que desponta e se torna um elo entre os diversos contos, permite que as personagens de Companheiros sejam vistas com características urbanas: malandros e espertos. Elas não são simples crianças, mas seres construídos por um espaço de câmbio, oscilante, em que o perigo e o medo acompanham a alegria, a possibilidade e a liberdade. Lugar em que as personagens são "prisioneiras do acanhado espaço que lhes foi reservado". O espaço da miséria, da fome, da exploração e da repressão, o espaço do medo do negro pela polícia" (FERREIRA, 2007, p.123). Porquanto, a descrição de Huambo possui um aspecto político. É mestiço por excelência. É este espaço que acolhe indistintamente a

\section{4}


todos e no qual as personagens do conto atuarão.

Quanto ao outro elemento (infância), temos três rapazes, Negro João, “de olhos jovens”, Armindo Mulato, de olhos "malandros" e Calumango, de "olhos receosos, espantados" (VIEIRA, 2007, p.93-94). A questão do olhar permeia a narrativa e transmite ao leitor um novo grau de personalidade da mesma. O olhar desvela os meandros da narrativa e permite-nos entrever as mudanças psicológicas ocorridas no texto. Assim, sabemos que Negro João, apesar de ter sido apresentado em primeiro na narrativa, ainda é jovem, menos malandro. Calumango é ainda um menino espantado, que acha tudo que vê novidade; um ente perdido com sua infância no meio de um espaço dissoluto. Já Armindo Mulato é o sujeito esperto, aquele que nota antes mesmo que aconteça - o mais experiente se analisado pela perspectiva visual.

As três personagens encontram-se nas ruas de Huambo e seguem junto a realizar trabalhos que os sustentam nas ruas. Assim, enquanto Negro João vende jornais, Calumango e Armindo Mulato engraxam sapatos. Aparentemente, não há nada de atrativo na narrativa que possa chamar a atenção dos leitores, mas, como bem esclarece Ferreira, "é no subtexto que reside a real intenção significativa do autornarrador" (2007, p.124). É sempre metaforicamente que a narrativa se revela. Isso porque são construídas dentro de uma realidade social de dominação, ou seja,

[...] se trata de uma sociedade colonizada, a presença do colono, direc- 
ta ou indirectamente, adquire uma constante significativa. Assim o universo que se vai desenhando a nossos olhos é marcado pela existência de uma disponibilidade real e intensa para a sobrevivência, torneando a barreira da humilhação. Daí que o enunciado se transforme em denúncia, é a palavra. [...] Libelo que se dimensiona quando o registro é essencialmente feito da fome, da injustiça nos comportamentos dos que dominam, seja a que nível for, de repressão ou desse diabólico interveniente que é o veneno racial.

(FERREIRA, 2007, p.121-122)

Sendo assim, o subtexto propõe um jogo entre revelar e ocultar, como demonstra o narrador logo no início do conto: "Palavras que ele queria explicar bem para João e Calumango, mas não podia. Palavras que faziam de todos os portos do mundo, portos de todo o mundo" (VIEIRA, 2007, p.94). O narrador dispõe a seu leitor que há algo a ser narrado, algo em segredo, que transformará os portos do mundo em portos de todos. Dessa forma, o subtexto desmascara, subliminarmente, a intenção social da narrativa. A utopia presente no excerto permite ao leitor entrever que o jogo proposto pelo 
narrador é a troca do aprisionamento colonial por uma vida em liberdade, compartilhada. Ou seja, o anseio das personagens é o de trocar a prisão do sufocamento e da exploração de Huambo pela “(...) vida livre de Luanda. O mar, sobretudo o mar" (VIEIRA, 2007, p. 95).

O narrador recorre ao mar - metáfora de liberdade - para aproximar o anseio de Armindo Mulato ao de seus amigos Negro João e Calumango. Tal anseio é tão forte que Armindo chega a ver o mar, sente sua presença. É em favor dessa liberdade sentida que Armindo Mulato convida seus companheiros a "fazer como em Luanda".

Entretanto, neste espaço em que a liberdade é vigiada, Armindo é capturado pela guarda. Os amigos correm para ajudá-lo, mas Armindo rejeita a ajuda deles assumindo toda a culpa. É neste ponto que temos o maior grau de tensão da narrativa, momento em que o alumbramento toma conta de todas as personagens. Armindo aceita seu destino enquanto o policial, num ato visual, percebe que está só. Afasta-se então arrastando Mulato Armindo, com medo de Negro João e Calumango. Temos a força colonial posta em xeque, demonstrando seu medo perante o povo e, principalmente frente à juventude. O narrador, com tal ação, consegue ficcionalizar os desafios vividos pelos marginalizados que habitam a periferia de Huambo/Angola e sublinhar o potencial de resistência dos habitantes dessa periferia mestiça. Assim, notamos que são tais subterfúgios que permitem ao narrador elaborar um discurso em função de um projeto político. 
A luta entre Armindo Mulato, representante do povo angolano, e o polícia, representante da PIDE e, mais profundamente, da opressão colonial, deixa em aberto novas possibilidades de configuração social. É por conta dessa abertura que Calumango transita da inocência infantil para a sapiência malandra: "Sentiu qualquer coisa dentro de si partir-se. Os punhos cerraram-se. Não era mais Calumango, rato do mato! Não era mais" (VIEIRA, 2007, p. 97). O representante do medo, da escuridão e da mansidão se descobre outro, sua transitoriedade permite entrever que o olhar ensinado por Armindo permanecerá. Assim, o narrador evoca novamente a questão visual para encerar seu conto, demonstrando que é o mesmo que permite a transformação social:

Negro João, Calumango, rato do mato, lá ficavam na vida!

Olharam-se ambos. O olhar dizia as mesmas palavras do amigo que ensinava a ler, que ensinava a não ter medo. As palavras que ele tinha ouvido, desenhadas nos lábios do primo marinheiro de muitos portos e muitas águas, cresciam dentro deles. Palavras que faziam de todos os portos do mundo, portos de todo o mundo . (VIEIRA, 2007, p.98)

A esperança de Armindo é transmitida, via olhar, 
para Negro João e Calumango, e estes assumem a perspectiva socialista utópica expressa pelos portos de todo o mundo e creem que a situação de opressão será apenas transitória. A sugestão revolucionária inscrita na linguagem de Vieira, como o mesmo já havia revelado ${ }^{1}$, demonstra que esta também pode ser literária, assim sua narrativa faz com que o leitor conheça de perto a realidade dos oprimidos e que se posicione em relação à luta por sua libertação. Fazer com que este leitor conheça esta realidade não o obriga a adotar uma ação em favor dos angolanos, antes, imprime um caráter optativo, já que a narrativa não impõe, mas sugestiona seu leitor e lhe lança o desafio de optar ou não por ter portos de todo o mundo. O engajamento literário aqui ultrapassa a normatividade do socialismo/comunismo e equaciona a realidade ambivalente de toda sociedade.

E é aqui que reside uma das grandes qualidades do literário no texto de Vieira: a clara possibilidade de participação direta do interlocutor. Isto é, o princípio bakbtiniano de dialogismo se aplica a textos nos quais as vozes que se entrelaçam no desenvolver da narrativa discutem entre si e com o

$1[\ldots]$ mas depois, quando entramos na luta política pela independência do país, que foi feita em nome das camadas que não tinham voz - e se tivessem não podiam falar, e se falassem não falariam muito tempo... - foi aí que os escritores angolanos resolveram dar voz àqueles que não tinham voz e, portanto, escrever para que se soubesse o que era o nosso país, se soubesse qual era a situação do país e, desse modo, interferirem de maneira a modificarem essa situação [..] (VIEIRA, 1989, p.10). 
interlocutor, de maneira a levá-lo a refletir e a se identificar sem imposições. Além dessa interação autor-texto-interlocutor possibilitada pelo elemento dialógico, há uma postura menos centrada na defesa de uma causa por meio do maniqueísmo barato, antes uma apresentação ficcional próxima ao factual de forma engajada e militante.

Em Luandino Vieira, a literatura age criticamente, revelando situações e vivências dos dominados, silenciadas pelos dominadores e, mais que isso, dá voz e esperança aos primeiros. Dessa forma, sua escrita possui uma forte preocupação com o Outro, um olhar que não se desvia dos problemas, ao contrário, revela-os. Esta preocupação pode ser vista também nos romances de Jorge Amado, nos quais a expressão literária é juntamente com seus temas e formas, uma opção política. Assim, tanto o livro quanto o conto de Luandino Vieira revelam grande proximidade com Capitães de Areia, escrito em 1937 por Jorge Amado. O tema de meninos pobres e abandonados ao léu do espaço urbano de uma metrópole que os esmaga, a perseguição policial e a intenção de atingir seu leitor presentes no escritor angolano são muito similares no livro em questão de Jorge Amado. Temos que este romance serviu de mote para a preparação daquele conto, erigindo o diálogo, dentro dos moldes bakhtinianos, enquanto proposta estética e política.

O livro de Jorge Amado inicia-se com uma série de cartas escritas à redação do Jornal da Tarde, nas quais há o relato de várias histórias sobre os meninos de rua, conhecidos 
popularmente como capitães da areia, e sobre o reformatório da cidade. Tal expediente demonstra que o livro trará um relato de deflagração sobre o tratamento destes meninos tanto na Bahia quanto, por contiguidade, no Brasil. Tal forma de narrar, que questiona a realidade nacional de forma polêmica encontra nos contos do escritor angolano uma identificação, como que uma resposta de Vieira à situação dos meninos de rua do espaço de Huambo, metonímia de Angola.

Assim, não é de se estranhar que tanto os meninos de Amado quanto os de Vieira expressem conceitos socialistas de vida: Pedro Bala, protagonista de Capitães de Areia e menor abandonado. Após vivenciar uma estadia com os menores de rua da Bahia, toma consciência de sua posição social e, utopicamente, busca transpor os obstáculos sociais por meio de um senso de coletividade, impingindo a si mesmo uma presença de valores e ideais de luta em favor dos trabalhadores e oprimidos de toda ordem. Sua voz representa a voz dos marginalizados vendidos ao trabalho capitalista e, por sua luta, tenta convencer e trazer consigo o leitor, em favor de uma vida mais justa a estes homens sem voz e vez. Tal atitude coloca Pedro Bala exatamente ao lado de Armindo Mulato, a personagem chave de Companheiros que expressa, por sua vez, a figura chave que leva os companheiros de rua a terem uma atitude utópica de crença na mudança social por meio da coletividade. É por isso que as personagens encerram o conto abraçadas em busca de um porto de todos.

Tanto no brasileiro quanto no angolano, há uma 
espécie de diminuição da voz narrativa em favor de uma outra voz, uma voz autoral que se infiltra nos interstícios da narrativa e dialoga, intratextualmente com o leitor. Um autor implícito no dizer de Booth (1980). Essa voz que mistura elementos do ficcional e do factual seduz seu visado leitor usando efeitos estéticos que mobilizam o mesmo através da linguagem para conservar sua atenção, emocioná-lo, mover seu ânimo. Ao ceder voz aos marginalizados, os autores em questão condenam os malefícios do capitalismo e propõem a viabilização de um projeto de sociedade renovada.

$\mathrm{O}$ apelo social, representado por crianças que passam fome e não têm roupas transforma a narrativa de Amado em uma espécie de epopeia social, que retrata a vida do pobre em busca de possibilidades de vitória. Por outro lado, temos um Bildungsroman, já que está exposto, de forma pormenorizada, o processo de desenvolvimento físico, moral, psicológico, estético, social e político de Pedro Bala. Vemos sua passagem da infância para um estado de maturidade, no qual o social transmite um sentido moral, uma mensagem política. Assim, é João de Adão quem vai propiciar a Pedro Bala o início dessa aprendizagem por meio das histórias referentes ao pai do protagonista. Esta conversão, por meio das narrativas de João de Adão, serve de apoio ao narrador para direcionar seu leitor a verificar que é a ação em favor do coletivo levada a cabo por Loiro - pai de Pedro Bala - que leva seu filho à maturação. O despertar de Pedro Bala acontece pela descoberta de que seu pai foi um homem respeitado e que lutava pelos direitos de todos. Loiro 
torna-se um herói para seu filho. As greves e manifestações organizadas pelo pai do protagonista fazem com que seu filho tenha em quem se espelhar. O narrador, conduzindo habilmente seu leitor, faz com que o mesmo sinta o desejo do protagonista: O navio apitava nas manobras de atracação. De todos os cantos surgiam estivadores que se iam dirigindo para o grande armazém. Pedro Bala os olhou com carinho. Seu pai fora um deles, morrera por defesa deles. Ali iam passando homens brancos, mulatos, negros, muitos negros. Iam encher os porões de um navio de sacos de cacau, fardos de fumo, açúcar, todos os produtos do estado que iam para pátrias longínquas, onde outros homens como aqueles, talvez altos e loiros, descarregariam o navio, deixariam vazios os seus porões. Seu pai fora um deles. Somente agora o sabia. E por eles fizera discursos trepado em um caixão, brigara, recebera uma bala no dia em que a cavalaria enfrentou os grevistas. Talver. ali mesmo, onde ele sentava, tivesse caído o sangue de seu pai. Pedro Bala mirou o chão agora asfaltado. Por baixo daquele asfalto devia estar o sangue que correra do 
corpo de seu pai. Por isso, no dia em que quisesse, teria um lugar nas docas, entre aqueles homens, o lugar que fora de seu pai. E teria também que carregar fardos... Vida dura aquela, com fardos de sessenta quilos nas costas. Mas também poderia fazer uma greve assim como seu pai e João de Adão, brigar com polícias, morrer pelo direito deles. Assim vingaria seu pai, ajudaria aqueles homens a lutar pelo seu direito (vagamente Pedro Bala sabia o que era isso). Imaginava-se numa greve, lutando. E sorriam os seus olhos como sorriam os seus lábios.

(AMADO, 2008, p. 87, grifos nossos)

É justamente a fé e a imagem positiva que tem de seu pai que transformam a atitude de Pedro Bala. O narrador direciona o leitor a notar que foi por conta dos direitos dos trabalhadores que Pedro Bala sonhara lutar e, quem sabe, até morrer. A marca do sangue paterno, mesmo coberto pelo asfalto, faz com que o protagonista do romance assuma uma postura de continuidade, de perseverança no sonho do pai, e, por contiguidade, com que sua esperança contagie o leitor.

Há, neste processo narrativo, uma espécie de confronto entre duas posições actanciais: a utopia e o pessimismo. Se por um lado Pedro Bala encontra motivos para crer que sua 
vida pode mudar, que há alguém em quem se espelhar e de que é possível que a sociedade mude, por outro lado temos as diversas personagens da narrativa afirmando que isso é deveras impossível. Esse processo de despertar em forma de amadurecimento via embate, presente nos bildungsromane, também aparece na narrativa de Vieira, mas de uma forma diferenciada. Se em Amado temos um despertar que acontece aos poucos, em Companheiros há uma espécie de alumbramento habilmente manipulado no texto, de forma a fazer com que as personagens não passem por todo um processo de amadurecimento, mas que se transformem rapidamente, já que a narrativa de Vieira prima pela condensação. As personagens Negro João e Calumango despertam para a maturidade por meio de um ato simples de seu companheiro, uma ação que os faz despertar para uma visão otimista, fundamentada na fé revolucionária e na convicção do poder humanizador do socialismo. A aura da estória de Vieira está na restituição do marginalizado à condição de herói. Dessa forma, os autores se encontram novamente por meio de seus processos de revitalização da figura do desclassificado social.

Há, no livro de Jorge Amado, um capítulo central que, por dialogar perfeitamente com o conto Luandino Vieira, tomaremos como central em nossa análise. Este capítulo é intitulado pelo escritor baiano, interessantemente, como Companheiros. Além da identificação dos títulos, os motes narrativos são parecidos, demonstrando a proximidade dos dois escritores. Na narrativa de Amado, o enredo resume-se à vontade de um grupo em fazer greve e, para isso, chamam os capitães da 
areia para ajudar, pedindo para que os mesmos impeçam que haja furos na greve. Após alguns incidentes, os meninos realizam sua missão e conseguem fazer com que a greve aconteça. Ora, o capítulo demonstra, de forma espetacular, como a força das massas se sobrepõe ao poder oficial. Os meninos, apesar de estarem a margem da sociedade, conseguem transformar a mesma por meio de sua união. Essa transformação também é expressa no texto de Vieira quando as personagens Negro João e Calumango decidem ajudar Armindo Mulato. Mesmo sendo representante do poder e tendo a lei ao seu lado, o policial recua por medo das duas personagens. Ele é salvo por sua própria cobaia, que pede aos amigos que o deixem ir em paz em favor da liberdade dos dois que seria cerceada. Este medo expresso pelo policial demonstra o respeito que a marginalidade possui. Assim, ao fugir das personagens soltas, o representante do cerceamento reconhece a autoridade dos mesmos, respeitando-os. O mesmo acontece com Pedro Bala e seus companheiros; quando estes chegam a um bar, são desrespeitados pelos presentes e tentam se impor por meio do dinheiro. Mas o respeito só advém quando os presentes ouvem da boca de João de Adão que Pedro Bala é filho de Loiro. Ou seja, o respeito alcançado por aquele que lutou pelo povo se ressignifica na figura de seu filho e dos companheiros do mesmo.

O cotejo aqui realizado nos permite, por fim, elencar alguns parâmetros necessários. É notável, inicialmente, que a literatura de ênfase social em língua portuguesa apresenta parâmetros estético-ideológicos que se identificam supranacional- 
mente, ou seja, os escritores, para além de sua militância, se leem e dialogam entre si, seja presencial ou literariamente, estabelecendo linhas de desenvolvimento da escrita de cunho social engajada no contexto de língua portuguesa. As transformações, distribuições e desenvolvimento das formas literárias são reciprocas e intercambiam, tendo a figura do baiano Jorge Amado como grande gerenciador destes elementos. Assim, é possível notar que existe uma problemática no seio das nações de língua portuguesa, mas que estas, no quesito do trabalho literário, trilham um caminho de “(...) construção de um texto como resultado de outros textos, através de um trabalho poético de absorção e transformação, dentro das produções de cada um dos ficcionistas (...)" (ABDALA JR., 1981, p.35).

Luandino Vieira é uma referência obrigatória no processo de afirmação e consolidação da literatura angolana, já que imprime à sua obra uma perspectiva questionadora da realidade nacional. Jorge Amado, por sua vez, contrapõe a sociedade ideal a modelos sociais mais humanos, denunciando a segregação social e racial através de um tratamento estilístico da linguagem literária que polemiza a herança canônica. Tais escritores, mais que irmãos de escrita, são exemplos vivos de que a literatura pode - e deve - ser elemento de transformação social.

\section{Referências}

\footnotetext{
ABDALA JR., Benjamin. A escrita neo-realista. São Paulo: Ática, 1981.
} 
AMADO, Jorge. Capitães da areia. São Paulo: Companhia das Letras, 2008.

BOOTH, Wayne C. A retórica da ficção. Trad. Maria Teresa H. Guerreiro, Lisboa: Arcádia, 1980.

CHAVES, Rita. O Brasil na cena literária dos países africanos de língua portuguesa. In: http://bibliotecavirtual. clacso.org.ar/ar/libros/aladaa/chaves.rtf. Acessado em 28 out $/ 2012$.

COUTO, Mia. E se Obama fosse africano? São Paulo: Companhia das Letras, 2011.

EVERDOSA, Carlos. Cartas do Tarrafal. In: LABAN, Michel. Luandino. José Luandino Vieira e a sua obra. Lisboa: Edições 70, 1980.

FERREIRA, Manuel. A libertação do espaço agredido através da linguagem. Prefácio à 2. ed. (1977). In: VIEIRA, Luandino. A cidade e a Infância. São Paulo: Companhia das Letras, 2007.

VIEIRA, Luandino. A cidade e a Infância. São Paulo: Companhia das Letras, 2007.

.Um escritor confessa-se... Entrevista de Luandino Vieira. In: Jornal de Letras, Artes e Idéias. Lisboa, 09/05/1989, p. 10. 


\title{
O Querer-dizer de Jorge Amado no viés popular
}

\author{
Maria Divanira de Lima Arcoverde
}

\section{Introdução}

Jorge, mais do que Amado, se insurge neste colóquio, como "o ícone da literatura baiana" que ultrapassa os limites dos interstícios discursivos. Considerado um escritor atemporal, suas obras foram publicadas em cinquenta e cinco países e quarenta e nove idiomas e adaptada para outras mídias como televisão, cinema e teatro. Assim, seus personagens são transformados em parte indissociável da vida brasileira. Amante de expressões populares, o discurso de Jorge Amado torna-se inconfundível em suas obras literárias. Considerado um escritor coloquial por excelência, embora dominasse a variante culta, ele poderia dizer: "Meta a mão na cabaça quem quiser, não eu" (CASTILHO, 2008).

$\mathrm{Na}$ visão de Citoaian (2012), não se conhece na literatura brasileira obra social e vida mais densas do que teve Jorge Amado. Lutou a boa luta, não se omitiu, não tremeu, não foi o "coelho assustado" em que muitos intelectuais se transformaram diante da força. Despertou ódios. Teve livros apreendidos e queimados. Foi preso, perseguido, exilado, expulso da França e proibido (ele e seus livros) de entrar nos Estados Unidos. Mas, tudo isso, é um passado heroico que não pode ser anulado na base do "esqueçam o que escrevi”. 
Dentre os "perigos da literatura", no dizer de Todorov, está a permanência.

Suas obras relançadas a partir de 2008, pela Companhia das Letras, é um atestado de que mesmo tendo sido vítima de "um curto desdém da crítica", ele se manteve firme em seu projeto de cultura popular, pois "Quem engorda o gado é o olho do dono". Em seus propósitos de incorporação da linguagem popular, não dispensa as frases feitas, os provérbios, as gírias e os palavrões. Nas palavras do Prof. Eduardo de Assis Duarte - da Universidade Federal de Minas Gerais (UFMG), o coloquialismo em Jorge Amado é uma característica marcante das marcas literárias da opção militante do escritor baiano. Amado queria "escrever para o povo", seguindo o exemplo de escritores que, mundo afora, abraçaram a utopia socialista. Era um contador compulsivo de histórias e se a literatura para ele era vida, o seu "querer-dizer" também significava vida. Nesse processo de elaboração, Jorge Amado, na reflexão glissantina, "traça um 'rizoma com o mundo', irrigando a escrita na delicada busca de deciframento do real, tanto em campo estético, quanto nos campos histórico, político e ideológico" (GLISSANT, 2005, p.13).

Neste sentido, a dinamicidade da criação linguajeira de Amado, situada no universo da cultura, se dimensiona como um grande diálogo, cuja teia discursiva se desenvolve sob a base da materialidade linguística de discursos já-ditos. Isto provoca uma produção literária múltipla, levando em conta que a literatura é parte inalienável da cultura. 
Assim, o trabalho que ora apresentamos, se inscreve no Querer-dizer de Jorge Amado no viés popular, volvendo o nosso olhar para recortes de retomadas de discursos populares, especificamente, enunciados de curta extensão, introjetados como redes de significação na obra $A$ morte e a morte de Quincas Berro D’Água (2008).

\section{Os enunciados de curta extensão}

Refletir sobre a linguagem como objeto social, nos faz pensar sobre as formações da vida no cotidiano e nas interações verbais que se instauram entre interlocutores, sejam por meio de construções complexas ou as mais simples, como os provérbios, ou ditos populares, como são popularmente conhecidos, slogans, aforismos e tantas outras. Mergulhar nesses entrelaçados, cujos fios se sobrepõem e se enredam, como a fluir enunciativamente ou a se desalinhar no processo de nosso conhecimento, faz com que nos aproximemos dos vários sentidos que essas produções evocam.

$\mathrm{Na}$ concepção bakhtiniana, o enunciado concreto sempre une os participantes da situação comum como co-participantes que conhecem, entendem e avaliam a situação de maneira igual. O enunciado, consequentemente, depende de seu complemento real, material para um e o mesmo segmento da existência e dá a este material expressão ideológica e posterior desenvolvimento ideológicos comuns. (BAKHTIN; VOLOCHINOV, 1999, p.06).

Em Discurso na vida e na arte, Bakhtin afirma que 
um enunciado concreto como um todo significativo compreende duas partes: a) a parte percebida e realizada em palavras e b) a parte presumida. Nesse sentido, o enunciado pode ser comparado ao entimema, isto é, uma forma de silogismo em que uma das premissas não é expressa, mas presumida. No entanto, um enunciado concreto é um tipo especial de entimema, pois nas atividades da vida é um entimema social, objetivo. Ele é como uma "senha" conhecida apenas por aqueles que pertencem ao mesmo campo social. A característica distintiva do enunciado concreto consiste precisamente no fato de que eles estabelecem uma "miríade" de conexões com o contexto extraverbal da vida e, uma vez separados deste contexto, perdem quase toda sua significação.

Nestas esferas de realidade se intercalam os enunciados de curta extensão. Os enunciados de curta extensão são também maneira de usar a língua de modo conciso e pitoresco, cujo funcionamento atesta uma vertente processual que pode ser chamada de formações sociais discursivas. Essa relação dos acontecimentos discursivos teria como base mecanismos sócio-enunciativos e, mais amplamente, a abordagem da interação verbal, tendo em vista que o discurso verbal é um evento social. Ele não está autoencenado no sentido de alguma coisa, ou quantidade linguística abstrata, nem pode ser derivado psicologicamente da consciência subjetiva do falante tomada em isolamento. É a "alma social" do discurso que o torna belo ou feio e que lhe dá significado artístico. O enunciado concreto, como afirma Bakhtin, (e não a abstração linguística) nasce, 
vive e morre no processo da interação verbal/social entre os participantes da enunciação.

Os enunciados de curta extensão por serem considerados, como um elemento familiar, ao mesmo tempo, apresentam novidades e estranhamento porque rompem com o fio do discurso. Assim, são considerados como patrimônio comum, de um dizer conhecido por todos, não necessita, de comentários metalinguísticos ou mesmo de entoação especial para serem percebidos como um discurso diferenciado. Eles são também uma modalidade privilegiada de discurso do Outro, configurando o processo da alteridade.

Neste sentido, ao reenunciar o discurso do outro, o sujeito não está assumindo uma atitude passiva, mas interagindo no processo discursivo. Ouvir a voz do outro é caminhar para a constituição de uma subjetividade. A função das vozes narrativas amplia-se por meio de enunciados populares, estabelecendo um diálogo entre o "outrora e o agora". A alteridade então se vincula pela emergência do discurso do outro, aquele discurso que já foi dito, mas que se evidencia ao ser reeditado na reversibilidade do tempo e caracterizado por recorrências e analogias.

São essas recorrências que funcionam como dispositivos de uma memória discursiva. Os fatos do discurso, enquanto inscrição material em uma memória discursiva vêm restabelecer os implícitos (os pré-construídos, elementos citados e relatados, discursos transversos etc). $\mathrm{Na}$ visão de Pechêux (1999), a questão se dá em saber onde estão esses 
famosos implícitos, que estão "ausentes por sua presença". Eles estão disponíveis na memória discursiva como em fundo de gaveta, um registro do oculto? Esse efeito de opacidade que marca o momento em que os implícitos não são mais reconstruíveis é, provavelmente, o que compele a análise do discurso a se distanciar das evidências da proposição.

Dessa forma, a memória como interdiscurso é o saber discursivo que faz com que ao falarmos, nossas palavras façam sentido. Ela se constitui pelo já-dito que possibilita todo querer-dizer. Assim, Jorge Amado, como "sujeito assujeitado" é historicamente determinado pelo interdiscurso, pela memória do dizer, afetado pela língua e por algo que falou antes, em outro lugar. Palavras já-ditas, às vezes, esquecidas, ao longo do tempo e de nossas experiências de linguagem.

Os enunciados de curta extensão são considerados um interdiscurso, um tipo de expressão que, por representarem um valor social, podem funcionar em espaços discursivos distintos, ressaltando um traço relevante pelo fato de romperem na cadeia do significante, da qual o falante seria a principal fonte, o reconhecimento de que existe uma voz que falou antes dele. Ou seja, a voz de uma sabedoria anônima e popular, o que estabelece a ruptura, pois como sabemos, o usuário desses enunciados julga-se "o dono" desse dizer.

Dentre outras produções do cotidiano, os enunciados de curta extensão se inserem como caracterizados por uma constituição discursiva, marcada por um número reduzido de palavras que são mobilizadas na sua organização frasal,

\section{4}


mas com propriedades linguístico-discursivas próprias. Cada um desses pequenos enunciados mobiliza recursos estilísticos, temáticos e composicionais bastante específicos. Estes enunciados, na visão de Baronas (2011), se por um lado, precisam de um gênero discursivo que os aninhe, que lhes dê guarida, por outro, extrapolam todo e qualquer gênero. Eles acabam por adquirir autonomia discursiva em relação ao texto primeiro, organizando-se com sentido próprio. Estas expressões pertencem geralmente a um alhures discursivo, ou seja, ditos em outro lugar por um "sujeito universal" em que nem o contexto situacional nem o cotexto original são recuperáveis linguisticamente. Porém, como afirma Baronas (2011), sabemos que eles pertencem à sabedoria de uma certa comunidade.

Assim, esta linguagem cotidiana, usada nos mais diversificados horizontes sociais, em contextos e gêneros textuais variados, vai tecendo as inúmeras tramas que possibilitam o diálogo na abertura de fios que se entrelaçam na configuração dos discursos. Sem nome próprio, todas as espécies de linguagens dão origem a essas festas efêmeras que surgem, desaparecem e retornam. Por isto, a criação popular não tem nome; é coletiva; não tem autoria.

É nessa perspectiva que esses enunciados se constituem, fazendo parte de uma pluralidade cultural, que não pode ser hierarquicamente ordenada ou privilegiada, mas respeitada pela sua inviolável diversidade de modo de ser, de se manifestar culturalmente. A cultura passa a ser, então, uma força politicamente relevante, caracterizada por uma tendên- 
cia que tudo permeia, estreitamente aliada à vida social, cujo complexo de valores, costumes, práticas de vida e produções discursivas constituem um hibridismo geopolítico, cultural e étnico. Essas características sinalizam o entendimento da cultura popular como um saber coletivo, produzido por processos cognitivos e heterogêneos, em função dos quais os indivíduos definem as suas esferas de realidade.

Esses hibridismos consistem em intersecções entre culturas, e estabelece como propósito das ciências sociais situar-se entre as culturas nos lugares de cruzamento, fusões, conflitos e contradições. Jorge Amado insere em suas obras um intercâmbio cultural, ao conceber seus personagens, seus dizeres, tão verdadeiros quanto o querer-dizer do autor. No entanto, segundo Amorim (2001), na realidade, o autor não tem uma verdade acabada sobre seu personagem e ele entra em diálogo e se deixa alterar pela palavra do personagem. Para esta autora, é esta a condição primeira para o fenômeno do dialogismo bakbtiniano em relação à palavra do personagem, para que não se funda com o autor, "não lhe sirva de portavoz". A palavra de um personagem nunca é plena, acabada; ela se busca na palavra dos outros, que é quando faz sentido.

\section{0 querer-dizer e o já-dito}

Os discursos literários dialogizam socialmente a linguagem e são produzidos por fios ideológicos que os tecem por meio de relações dialógicas. Sabendo-se que a linguagem é dinâmica e que retoma os dispositivos teóricos, na perspectiva 
bakbtiniana, verificamos que a linguagem "é um produto da vida social que não é de nenhum modo congelado ou petrificado: ela está em perpétuo vir a ser e, em seu desenvolvimento, ela segue a evolução da vida social" (BAKHTIN, 1999, p. 55).

Sendo assim, os discursos são produzidos pelas filiações de sentidos constituídos em outros dizeres. O quererdizer não é propriedade particular. As palavras não são nossas. Elas significam pela História e pela língua. Para Orlandi (1999), há um "já-dito" que sustenta a possibilidade de todo dizer, na funcionalidade do discurso e suas relações com os sujeitos e a ideologia.

Bakhtin, como "fundador da discursividade", nos dá a certeza de que não há nenhuma escrita que não se coloque a palavra do Outro. Há sempre um sujeito que fala do outro lado (AMORIM, 2001, p.15). Derrida, citado por Amorim, também nos ensina que qualquer um pode declarar, sob juramento, que só tem uma língua e essa língua não é sua própria. É a língua do outro.

Desta forma, na esteira destes constructos, situamos o discurso de Jorge Amado como um fenômeno em que se entrecruzam todos os falares das linguagens sociais. Sua construção literária congrega uma linguagem socialmente típica e, em cada momento, histórica, assegurando um diálogo vivo que se constitui pelo "querer-dizer", pelo que "já foi dito" e pelo que tem a dizer.

É neste viés popular que o narrador de $A$ morte $e$ a morte de Quincas Berro D'Água (2008) vai tecendo os fios “da 
prosa inebriante de Jorge Amado" com todas as confusões que permanecem até hoje, "sem que se consiga distinguir o que é fato e o que é delírio etílico".

Assim é o mundo, povoado de céticos e negativistas, amarrados, como bois na canga, (grifo nosso) à ordem e à lei, aos procedimentos habituais, ao papel selado. [...] tentam apagar as horas intensamente vividas por Quincas Berro D’Dágua até sua partida, como declarou, em alto e bom som, (grifo nosso) aos amigos e outras pessoas presentes.

(AMADO, 2008, p.14)

Podemos observar que os enunciados em destaque são materialidades linguísticas de curta extensão, enquadrados como os provérbios, os aforismos, as máximas, dado o número reduzido de léxicos que mobilizam a sua organização. $\mathrm{Na}$ perspectiva discursiva possuem características próprias e são reconhecidos como o “já-dito” tendo em vista os aspectos composicionais que os especificam, constituindo um gênero textual distinto, facilmente reconhecível por fazerem parte do "Thesaurus" Cultural de um determinado grupo social.

Em outro fragmento da narrativa, destacamos as seguintes expressões:

Não tem cara de quem engana mari- 
do... Em compensação, devia ser um osso duro de roer... Santa mulher? Não acredito... (p.22). Não poderia mandá-lo plantar batatas... (p.26). E Vanda, com o rabo do olho, espiou o morto (p.28). Já Tio Eduardo explicava: Caro mesmo é o caixão. E os automóveis, se for acompanhamento grande. Uma fortuna. Não se pode nem morrer.

(AMADO, 2008, p. 22-31, grifo nosso)

Como vemos, Jorge Amado insere expressões populares de curta extensão em seu tecido literário, na certeza de que "o discurso do EU supõe uma dupla caricatura". Isto dá a entender que caracterizar o Outro é poder diferenciarse dele, mas ao não ter êxito nessa empreitada, representa, ao mesmo tempo, a "caricatura de si mesmo e de suas esperanças" (PONZIO, 2008, p.23). É, pois, no texto literário, como sistema simbólico de maior tradição, que encontramos a linguagem popular, assumindo um "entre-lugar", reinando como elemento híbrido (SANTIAGO, 2000). Para este autor, "a maior contribuição da América Latina para a cultura ocidental vem da destruição sistemática dos conceitos de unidade e de pureza" ( $p$ 16). Os conceitos de "pureza e unidade" perdem o contorno exato de seu significado; perdem seu peso esmagador, seu sinal de superioridade cultural, à medida que 
o trabalho dos latino-americanos se afirma e se mostra mais eficaz.

Amado situa-se, assim, neste "lugar aparentemente vazio", cumprindo um ritual que instaura o interdiscurso no campo literário, onde teríamos todos os dizeres “já-ditos” em uma estratificação de enunciados que representam o dizível.

Então Quincas Berro D’Água fazia seu solene juramento: reservara ao mar a honra de sua hora derradeira, (grifo nosso) de seu momento final. Não haviam de prendê-lo em sete palmos de terra (grifo nosso). Ah! Isso não!'(p. 49). (...) seus gritos cruzavam a ladeira de São Miguel, morriam no largo do Pelourinho, eram de cortar o coração. (AMADO, 2008, p.51, grifo nosso)

O saber discursivo de Amado foi se organizando ao longo da sua narrativa e produzindo dizeres que representam o eixo de sua constituição, ou seja, o interdiscurso. $\mathrm{Na}$ ótica de Orlandi (1999), as formulações feitas determinam o que dizemos. É preciso que o que foi dito por um sujeito específico e em horizonte social particular se apague na memória para que o "anonimato" possa fazer sentido em "minhas palavras".

Mostramos outro fragmento em que um enunciado de curta extensão muito conhecido é usado: "Tinha corrido 
a notícia de que Berro D’Água bateu as botas (grifo nosso). Tava tudo de luto. Quincas e os amigos riram"... (p.83).

Verificamos que o discurso dialogizado busca na memória discursiva um repertório humorístico por meio da linguagem conhecida por todos (BAKHTIN, 1999). A linguagem que provoca o riso nega o discurso de autoridade $\mathrm{e}$ afirma a relatividade das coisas. O discurso humorístico pertence à esfera particular da vida cotidiana e tem caráter lúdico e libertário. $\mathrm{O}$ enunciado bateu as botas, como unidade dialógica da língua foi aninhado no querer-dizer de Amado como um "já-dito", pertencendo a um alhures discursivo produzido originalmente por um sujeito universal. Este linguajar criado pela dinamicidade linguística é sociológico, dialógico e realizado pelo processo da interação verbal. É necessário esclarecer o que Baronas nos assegura:

Especificamente, as formas linguísticas de curta extensão congregam um conjunto de outros pequenos enunciados que, embora possuam características linguísticas semelhantes às dos provérbios, não se enquadram nesta categoria de formas linguístico-discursivas sobreasseveradas que se apresentam como elementos: a) relativamente breves, de estrutura pregnante no plano do significado e/ou do significante; b) em posição 
relevante no texto ou em uma passagem do texto de modo a lhe atribuir um estatuto de um condensado semântico, o produto de uma espécie de sedimentação da realização do discurso; c) (...) sua temática deve estar em relação com o intuito do gênero de discurso, do texto em questão; d) implica um tipo de "amplificação" da figura do enunciador, manifestada por um ethos apropriado.

(BARONAS, 2011, p.62)

\section{À Guisa de Conclusão}

Ao intentarmos analisar a linguagem popular na obra de Jorge Amado, era nosso interesse detectar a transposição de enunciados proverbiais no texto amadiano, tendo em vista os provérbios serem objeto de pesquisa em nossos estudos. No entanto, para nossa surpresa, a obra escolhida não propiciou este recorte. Direcionamos, então, nossa atenção para outros enunciados de curta extensão que, a exemplo dos provérbios, compõem um número significativo e inumerável de expressões populares, que povoam parte do repertório cultural das pessoas, usadas comumente no cotidiano. Ao registrar a incidência destes enunciados de curta extensão na obra A morte e a morte de Quincas Berro D'Água, poderíamos afirmar que Jorge Amado tinha o que Maingueneau (2001) chama de 
"vocação enunciativa", ou seja, o processo por meio do qual um sujeito se sente chamado a produzir literatura. Prova disso é o que Jorge Amado conta em seu livro autobiográfico $O$ Menino Grapiuna. Relata Amado que foi um professor de Língua Portuguesa, o Padre Luiz Gonzaga Cabral, o primeiro a dizer que ele seria escritor.

A linguagem de Amado, especificamente, o seu léxico precisa ser mais estudado. Esta linguagem chega a ser "erótica”, tátil... É mais que envolvente. Chega a ser sedutora. Para Castilho (2008), foi ao fundar sua linguagem no imaginário popular que Amado alcançou o seu projeto de literatura engajada.

Affonso Romano de Sant'Anna, no Posfácio da obra analisada, nos diz que Amado, fiel à oralidade como fonte de sabedoria popular, é um típico contador de histórias. Para ele, Jorge Amado constrói um "jogo de espelhos", um estilo "carnavalizador" como rito de inversão dos costumes, quando o avesso ocupa o lugar do certo. É a ficção virando realidade e o cotidiano e a fantasia se acoplando tanto quanto a vida e a morte. Acrescenta, ainda, que é "o êxito do arlequim sobre o pierrô, onde grotesco e sublime dialogam gostosamente. É a emergência do lado dionisíaco da existência" (p.101).

Vimos, assim, que Jorge Amado, mais que um romancista, mais que um escritor é aquele que encontrou "o entre-lugar" do discurso latino-americano, no dizer de Santiago (2000), para ancorar o seu querer-dizer, exercendo a potencialidade discursiva presente em todas as camadas 
sociais, em uso plural e dialógico. Interdiscursivamente, ele intercala em outro gênero as expressões de curta extensão, de autoria anônima e fortemente ligadas à tradição cultural, marcando desta forma, a alteridade que remete sempre a um Outro social.

O querer-dizer de Amado, marcado por um discurso de fácil reconhecimento, é vivificado pelo pragmatismo de seu uso no horizonte social, o que faz jus ao reconhecimento de suas obras estarem incluídas numa rede social que o destaca no cenário cultural e enunciativo do Brasil e do exterior.

\section{Referências}

AMADO, Jorge. A morte e a morte de Quincas Berro D’Água. São Paulo: Companhia das Letras, 2008.

AMORIM, Marília. O pesquisador e seu outro: Bakhtin nas ciências humanas. São Paulo: Musa Editora, 2001.

BAKHTIN, Michael; VOLOCHINOV, V. N. Marxismo e filosofia da linguagem. São Paulo: Hucitec, 1999.

BAKHTIN, Michael. A cultura popular na Idade Média e no renascimento. O Contexto de Francois Rabelais. São Paulo: Martins Fontes, 1997.

BARONAS, Roberto Leiser. Enunciados de curta extensão: 
gênero de discurso, aforização, Mídia e Política. In: Linguagem em (Dis)curso. Tubarão, SC: v.11, n. 1, p. 59-70, jan./ abr. 2011.

CASTILHO, Alceu Luis. O amante da expressão popular. In: Revista da Língua Portuguesa. Ano III. n.33. Jul/2008, p.23-32.

CITOAIAN, Ousarme. Jorge Amado. In: Universo paralelo. Ago/2012.

GLISSANT, Édouard. Introdução a uma poética da diversidade. Tradução de Enilce do Carmo A. Rocha. Juiz de Fora: Editora UFJF, 2005.

MAINGUENEAU, Dominique. O contexto da obra literária. São Paulo: Martins Fontes, 2001.

ORLANDI, Eni. Análise do discurso: princípios e procedimentos. São Paulo: Pontes, 2009.

PONZIO, Augusto. A Revolução Bakhtiniana. São Paulo: Contexto, 2008.

PECHÊUX, Michel. O papel da memória. In: ACHARD, Pierre.et al. Papel da memória. Tradução e Introdução de José Horta Nunes. Campinas, SP: Pontes, 1999. 
SANT'ANNA, Affonso Romano. Posfácio. In: AMADO, Jorge. A morte e a morte de Quincas Berro D’Água. São Paulo: Companhia das Letras, 2008.

SANTIAGO, Silviano. Uma literatura nos Trópicos: ensaios sobre dependência cultural. Rio de Janeiro: Rocco, 2000. 


\section{A Morte e a Morte de Quincas Berro D'áǵua: Carnavalização e Processos Estilísticos}

Nefatalin Gonçalves Neto

\section{Resumo}

O escritor baiano Jorge Amado possui uma vastíssima obra, divulgadora da cultura brasileira e composta em uma escrita bem peculiar, na qual a visualização da realidade social é uma constante enquanto elemento literário. Seus romances, traduzidos pelo mundo inteiro e com adaptações fílmicas, novelísticas ou para séries televisivas refletem a popularidade da escrita amadiana e sua forte característica ideológica, que erige a bandeira socialista e denuncia os desmandos do capitalismo. Entretanto, dentro deste seu complexo rol de romances e novelas, em que o social parece emergir enquanto elemento precípuo da narrativa há um pequeno texto em que a questão política parece ceder lugar a uma espécie de brincadeira literária de alta classe, sendo o espaço do bar e da aldrabice o locus de observação do narrador. A morte e a morte de Quincas berro d'água, novela que ganhou uma adaptação fílmica representa um espaço de diferença na obra de Jorge Amado, que merece ser levado em conta e analisado com o mesmo rigor que seus romances politizados. Dentro desta proposta de voltarmos nosso olhar para esta novela menos valorada do escritor baiano e, partindo dos estudos de Bakhtin que ava- 
liam os processos de construção do romance, nossa proposta é a de resgatar esta obra para o harém dos escritos qualitativos de Jorge Amado por meio da análise de seu viés carnavalizado. Nosso intuito será o de demonstrar sua qualidade literária, revelando a performance estilística da narrativa e um jogo de alta qualidade em relação ao foco narrativo.

Palavras-Chave: A morte e a morte de Quincas Berro d'água. Carnavalização. Estilística. Jorge Amado.

\section{Introdução}

Conhecido por seu cariz social, o escritor baiano Jorge Amado possui, no rol de sua obra, um romance que, aparentemente, foge ao pendor de tratamento literário por ele usado. Trata-se de seu A morte e a morte de Quincas Berro D'água, livro escrito e publicado em 1959. Considerado um dos clássicos amadianos, o livro relata as aventuras de um respeitável cidadão, funcionário público, que um dia muda seu destino e abandona sua família para viver como vagabundo.

A primeira vista, notamos que a questão da realidade social não é um elemento que se sobressai no texto, o que poderia levar o crítico mais desavisado a dizer que não há nele a característica da ideologia socialista de Amado, e que a denúncia e os desmandos do capitalismo são deixados de lado em favor de um texto cômico e, aparentemente, apolítico.

Se levarmos em conta que o autor parece ceder lugar, em seu escrito, a uma espécie de brincadeira literária de alta 
classe, sendo o espaço do bar e da aldrabice o locus de observação do narrador, notaremos então que não é tão sem ideologias o livro em questão. Representando um espaço de diferença, A morte e a morte de Quincas Berro D'água se filia a um espécie de narrativa que provém de fontes populares. Segundo Bakhtin (2008), há uma concepção literária com modo e estrutura particular que está "ligado mais profunda e estritamente que os outros às fontes populares [...]; essas fontes determinaram o conjunto de seu sistema de imagens, assim como sua concepção artística” (BAKHTIN, 2008, p.2). Este caráter popular explica sua promissão e seu aspecto "não literário", ou seja, sua resistência ao cânone e às regras de arte vigentes. Esse caráter "não oficial" é hostil à concepção de mundo estabelecido e, por seu anti-dogmatismo, impede a harmonização entre as imagens populares e à cosmovisão estabelecida pelos princípios canônicos e aceitos como corretos. Assim, se olharmos para $A$ morte e a morte de Quincas Berro D'água, notaremos que o mesmo possui uma resistência em ser canônico, o que nos possibilita a perscrutação de mais elementos do mesmo junto às fontes populares. A ausência de uma boa análise em relação ao livro de Amado decorre da falta de um olhar crítico, que interprete o mesmo sem moldes vinculados ao pensamento ideológico eurocêntrico e dominante. Um meio de decifrá-lo fora deste percurso dominante é "empreender um estudo em profundidade das suas fontes populares" (BAKHTIN, 2008, p.2)

Assim, o "riso popular e suas formas constituem o campo menos estudado da criação popular” (BAKHTIN, 
2008, p.3) e, quando examinado, é relevado a escanteio, ocupando apenas um lugar modesto. Entretanto, sua amplitude e importância são básicas, pois opõe o mundo com suas infinitas formas à cultura oficial, séria e religiosa. Expressa de diversas formas, - as festas públicas carnavalescas, os ritos e cultos cômicos, os bufões e tolos, os gigantes, anões e monstros, os palhaços, a literatura paródica, etc. - o riso popular possui "uma unidade de estilo e constituem partes e parcelas da cultura cômica popular, principalmente da cultura carnavalesca, una e indivisível" (BAKHTIN, 2008, p.4).

Entretanto, esse riso, carnavalesco por excelência, não é um fenômeno literário; é uma forma sincrética de espetáculo e de caráter ritual. Essa forma criou uma linguagem toda própria que exprime uma cosmovisão carnavalesca una e complexa, de diversas matizes e que tem a capacidade de penetrar todas as formas. Uma das linguagens suscetíveis de ser penetrada pela carnavalização é a literatura. A essa transposição "chamamos carnavalização da literatura.” (BAKHTIN, 1981, p.122). É este processo de passagem do carnaval para a literatura que se presentifica nos textos tanto de Rabelais quanto de Amado.

Tal riso, contido na cultura carnavalesca será o patrimônio do povo, que encontra sua forma de expressão via carnaval. Este é geral (de todos), universal (atinge a todos) e ambivalente (nega e afirma simultaneamente). Ele escarnece dos próprios burladores e expressa uma opinião do mundo centrada no diferente e tendo na literatura um espaço de expressão. Em literatura, esse espetáculo permite a quebra das hierarquias 
humanas, gerando o livre contato entre os homens, fato que a muito se encontra na literatura prosaica.

Os festejos cômicos - parte do processo de carnavalização - possuíam uma diferença de princípios. Tais diferenças ofereciam uma outra visão do mundo e das suas relações humanas, permitindo visualizar a dualidade do mesmo. Com o estabelecimento do regime de classes e de Estado, essas formas cômicas adquirem um caráter não oficial e, com o passar do tempo, transformam-se em "formas fundamentais de expressão da [...] cultura popular." (BAKHTIN, 2008, p. 5). Esses festejos possuem princípio próprio desprovido de exigências, além de se relacionarem ao espetáculo teatral por seu elemento de ludismo. Localizado entre a arte e a vida, o carnaval ignora a separação, fazendo seus espectadores viverem-no. Rompe as fronteiras da espacialidade e da liberdade, possuindo um caráter universal. No carnaval, "é a própria vida que representa e interpreta [...] uma outra forma livre de sua realização" (BAKHTIN, 2008, p.7). Dessa maneira, é este movimento cultural que penetra os meandros da narrativa e dá-lhe novo pendor artístico. Há ainda, segundo Bakhtin, as leis, proibições e restrições do sistema de ordem comum. Tais ações são revogadas no carnaval. Nele, "um novo modus de relações mútuas do homem com o homem" é forjado (BAKHTIN, 1981, p.123). Esse espetáculo permite a quebra das hierarquias humanas, gerando o livre contato entre os homens Assim, entram nos contatos e combinações carnavalescas todos os elementos antes fechados, separados ou distanciados pela visão hierárquica. O carna- 
val aproxima, reúne celebra os esponsais e combina sagrado e profano, elevado e baixo, grande e insignificante, sábio e tolo, dentre outros.

Insurgindo-se ao comum e às formas corriqueiras, a literatura carnavalizada - "literatura que direta ou indiretamente [...] sofreu de diferentes modalidades do folclore carnavalesco" (BAKHTIN, 1981, p.92) - apresenta aquelas formas de vida excluídas pela sociedade e que só são reveladas em momentos do extravasamento carnavalesco. O romance de Amado, à luz desse processo de desvelamento da exclusão via relações humanas diferenciadas, apresenta a vida de uma personagem altamente carnavalizada. Se o carnaval não consagrava a estabilidade por meio de um elo formal, era, por outro lado, a "abolição provisória de todas as relações hierárquicas, privilégios, regras e tabus" (BAKHTIN, 2008, p.8); se a literatura carnavalesca se opõe ao perpetuado, a personagem principal da novela que visamos a ler, numa encarnação humana deste princípio, "representa e interpreta" perfeitamente esta abolição da hierarquia, das regras e do tabu. A personagem, ao abandonar sua pacata vida de funcionário público e entregar-se aos chamados vícios mundanos, especialmente a bebida, insere-se no rol das personagens carnavalizadas, realizando a vida social de forma avessa à esperada:

Como pode um homem, aos cinquenta anos, abandonar a familia, a casa, os hábitos de toda uma vida, os conhecidos antigos, para vagabundear pelas ruas, beber nos botequins baratos, 
frequentar o meretrício, viver sujo e barbado, morar em infame pocilga, dormir em um catre miserável?

(AMADO, 2008, p.24)

Joaquim sai de seu mundo, do universo do bom pai, do bom marido, do homem respeitado e incorpora sua personagem carnavalesca, Quincas Berro D'água. Ao despir-se do terno e vestir-se de sua louca fantasia de homem do mar, Joaquim carnavaliza-se. A personagem assume a vida daqueles que não se integram ao pensamento ideológico da sociedade burguesa. Assim, essa assunção do escondido, caricato possibilita a libertação, uma vida nova e sem regras que só poderia ser aceita em dias de carnaval. Para a família, libertação é a primeira morte da personagem - aquela que apaga a figura de Joaquim e faz erigir a de Quincas. Entretanto, se para estes a libertação é uma morte, para o protagonista este é o início de sua verdadeira vida:

A verdade é que Joaquim só começara a contar em suas vidas quando, naquele dia absurdo, depois de ter tachado Leonardo de bestalhão, fitou a ela e a Otacília e soltou-lhes na cara, inesperadamente:

- Jararacas!

E, com a maior tranquilidade desse mundo, como se estivesse a realizar 
o menor e mais banal dos atos, foise embora e não voltou.

(AMADO, 2008, p.42)

Ao chamar a filha e sua esposa de Jararacas, a passagem em questão revela um princípio material da literatura carnavalizada, o chamado Realismo Grotesco. Para Bakhtin, este tipo de realismo carrega consigo imagens que são herança da cultura popular e de uma concepção estética de vida prática. Esse princípio aparece "sob a forma universal, festiva e utópica" (BAKHTIN, 2008, p. 17), e é profundamente positivo opõe-se a

toda separação de raízes materiais em si mesmo, a todo caráter ideal abstrato, a toda pretensão de significaşão destacada e independente da terra e do corpo. O corpo e a vida corporal adquirem simultaneamente um caráter cósmico e universal, não se trata do corpo e da fisiologia no sentido restrito e determinado que têm em nossa época; ainda não estão completamente singularizados nem separados do resto do mundo.

(BAKHTIN, 2008, p.17)

Seu centro capital são as imagens da fertilidade, do crescimento e da superabundância. $\mathrm{O}$ traço marcante do rea- 
lismo grotesco é o rebaixamento, a "transferência ao plano material e corporal, o da terra e do corpo na sua indissolúvel unidade de tudo que é elevado, espiritual, ideal e abstrato" (BAKHTIN, 2008, p.17).

O termo grotesco provém de uma pintura ornamental até então desconhecida que foi descoberta em Roma, nos subterrâneos das termas de Tito. Essa pintura, por possuir uma forma de arte diferente recebeu o nome de grottesca, que deriva de grotta (gruta). As características dessa forma de pintura era a do "jogo insólito, fantástico e livre das formas vegetais, animais e humanas que se confundiam e transformavam entre si" (BAKHTIN, 2008, p.28). Não havia fronteira entre esses reinos, elas são superadas pelo grotesco, que, apesar da junção de diferentes realidades possui uma liberdade e leveza na fantasia artística. Ao perder laços com a cultura popular, o grotesco degenera, se formaliza. Ele ressuscita, mas dotado de um novo sentido. Perde seu caráter pejorativo e alimenta diálogos com o fantástico e o maravilhoso, instaurando assim, uma nova visão de mundo, alicerçada no princípio carnavalesco de expressividade.

No realismo grotesco, a degradação do sublime tem um sentido "absoluta e rigorosamente topográfico" (BAKHTIN, 2008, p.18). O alto é o céu, mas também a cabeça (o rosto) e o baixo a terra e os órgãos genitais, ventre e traseiro. Seu valor é, ao mesmo tempo, negação e afirmação. O baixo no realismo grotesco é sempre a terra que dá vida, é o seio corporal, é sempre o começo. Assim, não é de se estranhar que 
a família, que ocupa um lugar social topograficamente alto, se insurja com a mudança de um de seus adeptos para o baixo. Ao assumir sua vontade, Quincas retorna ao seio corporal, ao começo de sua vida, agora não mais enquanto homem socialmente aceito, mas sim como sujeito carnavalizado. Essa caracterização de nascimento é afirmada pela narrativa quando se dá o novo batismo da personagem:

Não que seja fato memorável ou excitante história. Mas vale a pena contar o caso pois foi a partir desse distante dia que a alcunha de berro dágua incorporou-se definitivamente ao nome de Quincas. Entrara ele na venda de Lopez, simpático espanhol, na parte externa do Mercado. Freguês habitual, conquistara o direito de servir-se sem auxílio do empregado. Sobre o balcão viu uma garrafa, transbordando de límpida cachaça, transparente, perfeita. Encheu um copo, cuspiu para limpar a boca, virou-o de uma vez. E um berro inumano cortou a placidez da manhã no Mercado, abalando o próprio Elevador Lacerda em seus profundos alicerces. O grito de um animal ferido de morte, de um homem traído e desgraçado: 
- Águuuuua!

(AMADO, 2008, p.50-51)

Esse trânsito da ordem à desordem - visto pelos olhos do padrão estabelecido - só é completo quando, carnavalescamente, a personagem é batizada. Este batismo às avessas também é uma forma carnavalizada. Ao criar um tipo particular de comunicação, o batismo de Berro D'água caracteriza-o enquanto uma 'lógica original das coisas ao 'avesso', ao contrário, das permutações constantes do alto e do baixo (da roda), da face e do traseiro, e pelas diversas formas de paródia, travestis, degradação, profanações [...]” (BAKHTIN, 2008, p.10).

Uma das tendências das imagens grotescas do corpo é exibir dois corpos em um: um doador de vida que desaparece e outro que está para nascer. O corpo sempre está o quanto possível ao lado da vida e da morte: ventre e túmulo, seio que alimenta e que sepulta, e nessa tendência "os dois corpos se reúnem em um só” (BAKHTIN, 2008, p.23). O pensamento grotesco interpreta a luta entre vida e morte dentro do corpo como luta da vida velha e recalcitrante contra a nova vida nascente. Esse corpo, que é aberto e incompleto não está delimitado no mundo; o corpo é cósmico e representa o material e o corporal em todos os seus elementos. Dessa forma, a figura do protagonista carrega consigo essa imagem grotesca ao representar em si a morte de um sujeito aceito socialmente e o nascimento de um sujeito burlesco, carnavalizado. Essa ima- 
gem dos dois corpos em um é urdidamente trabalhada pelo narrador na cena em que os amigos Curió, Negro Pastinha, cabo Martim e Pé-de-Vento resolvem despir Quincas de suas roupas de Joaquim e colocar no mesmo as antigas vestes de malandro:

Negro Pastinha reclamou:

- Vocês não têm vergonha de disputar a mulher dele na vista dele? Ele ainda quente e vocês que nem urubu em carniça?

- Ele é que pode decidir.. - disse Pé-de-Vento. Tỉnha esperanças de ser escolhido por Quincas para herdar Quitéria, seu único bem. Não lhe trouxera uma jia verde, a mais bela de quantas já caçara?

- Hum! - fez o defunto.

- Tá vendo? Ele não está gostando dessa conversa - zangou-se o negro. - Vamos dar um gole a ele também... - propôs o Cabo, desejoso das boas graças do morto.

Abriram-lhe a boca, derramaram a cachaça. Espalhou-se um pouco pela gola do paletó e o peito da camisa.

- Também nunca vi ninguém beber deitado... [...]. 
- Bom paletó... - cabo Martim examinou a fazenda. - Besteira botar roupa nova em defunto. Morreu, acabou, vai pra baixo da terra. Roupa nova pra verme comer, e tanta gente por aí precisando...

Palavras cheias de verdade, pensaram. Deram mais um gole a Quincas, o morto balançou a cabeça, era homem capaz de dar razão a quem a possuía, estava evidentemente de acordo com as considerações de Martim. [...] Sentiam-se alegres. Quincas parecia também mais contente, desembaraçado daquelas vestimentas incômodas. Particularmente grato a Curió, pois os sapatos apertavam-lhe os pés. [...] Pé-de-Vento terminava de vestir as calças novas, cabo Martim ficara com o paletó. A camisa Negro Pastinha trocaria, num botequim conhecido, por uma garrafa de cachaça. Lastimavam a falta de cuecas. Com muito jeito, cabo Martim disse a Quincas:

- Não é para falar mal, mas essa sua família é um tanto quanto econômica. 
Acho que o genro abafou as cuecas... - Unhas-de-fome... - precisou Quincas. - Já que você mesmo diz, é verdade. A gente não queria ofender eles, afinal são seus parentes. Mas que pãodurismo, que somiticaria... Bebida por conta da gente, onde já se viu sentinela desse jeito?

(AMADO, 2008, p.75-78)

Apesar de grande, a citação é necessária, já que a realocação do homem em sua condição social realizada no excerto acima faz com que, novamente morra a figura de Joaquim, desta vez social e fisicamente e, por outro lado, renasça a figura de Quincas Berro D'água, seu oposto. Entretanto, mesmo com a morte de um e o nascimento do outro, temos como que uma ação duplicitária, de duas faces, afinal não há a existência de Quincas sem Joaquim e vice-versa. Desta maneira, o narrador incorpora a essência carnavalesca dos dois corpos em um por meio de uma manipulação discursiva plena ao erigir a figura de Jano como proeminente em sua narrativa.

No grotesco popular, mundo e homem se aproximam. O ser humano é corporificado e reintegrado por meio do corpo à vida corporal. Nesse esquema, a máscara possui grande importância, ela "traduz a alegria das alternâncias e das reencarnações" (BAKHTIN, 2008, p.35). Ela expressa as 
metamorfoses do ser e encarna o principio de jogo da vida, numa inter-relação da realidade e da imagem. Este esquema é fielmente "reproduzido" pelo livro de Amado, já que, mais que um ser completo, Quincas e Joaquim são máscaras de um indivíduo que viveu parte de sua vida enquanto sujeito de expressão da ideologia dominante e, posteriormente, se torna um sujeito que enfrenta esta postura, mudando sua posição.

A cosmovisão carnavalesca, para além do grotesco e da inversão topográfica, possui uma policromia exterior que demonstra ter sofrido "influência de diferentes modalidades do folclore carnavalesco" (BAKHTIN, 1981, p.107). Ou seja, o gênero carnavalesco se insere, deste ponto de vista, no estilo joco-sério. Sendo assim, o tratamento dado à realidade será diferencial em relação aos gêneros tradicionais ${ }^{1}$; esse tratamento causará, nos escritos que se filiam a este tipo de gênero, três grandes peculiaridades: a primeira será seu ponto de partida: a realidade viva e diária. E por ela que pela primeira vez o objeto de representação sério (e cômico) é dado sem nenhuma distância épica ou trágica, mas na zona de imediatez e de familiaridade. A segunda é que esses gêneros se baseiam conscientemente na experiência e na fantasia livre. E a terceira é "a pluralidade de estilos e a variedade de vozes de todos esses gêneros" (BAKHTIN, 1981, p.108). Ou seja, eles

1 Em termos poéticos, pode-se dizer que o gênero romanesco tem três raízes: a épica, a retórica e a carnavalesca. O romance, conforme a sua raiz, dá predomínio a um desses estilos, sendo que o carnavalesco encontra-se no campo do sério-cômico ou joco-sérios. 
renunciam a uma unidade estilística em favor dos elementos da cosmovisão carnavalesca.

Podemos notar estas três particularidades na novela amadiana. Primeiro porque ela parte não de uma pressuposição, mas da realidade de vida de diversas pessoas que habitam a sociedade baiana e, consequentemente, brasileira. O objeto representado - a vida de um bêbado e sua conturbada morte e velório - carrega, em sua expressão, uma exata contraposição em relação à épica ou trágica, ou seja, sua zona de familiaridade insere o leitor em contato direto com o ocorrido. A ação que se realiza no instante da narração é o princípio de condução da narrativa. Não sabemos da vida de Quincas aos poucos ao por meio de longos discursos e retomadas, mas de imediato e em contato direto, sem mediações. Por outro lado, como nos informa Sant'Anna (2008, p.95-98), a novela de Amado é baseada em fatos reais, tendo a realidade como elemento precípuo de construção da narrativa. Como diz o próprio crítico, o texto amadiano tem um sabor de cotidianidade, pois "[...] Jorge Amado tinha um ouvido danado de bom para converter fatos particulares em narrativas de utilidade público" (SANT'ANNA, 2008, p.97).

A segunda peculiaridade se apresenta por meio do jogo entre realidade e fantasia que a narrativa carrega a partir do momento em que o morto passa a viver e a beber com seus amigos. Essa hesitação faz do leitor um participante mais assíduo, comprometido com a leitura e sua significação, assim como o desenvolvimento da narrativa. Essa postura se dá 
porque, conforme Bakhtin, no carnaval não há divisão entre atores e expectadores; não se contempla o carnaval, mas vivese nele, e vive-se uma vida carnavalesca, ou seja, uma vida desviada da ordem habitual, uma vida às avessas, um mundo invertido (monde à l'envers) em que o arlequim alcança êxito sobre o pierrô, momento em que o dionisíaco se emergência em relação ao apolíneo.

Por fim, a terceira particularidade se apresenta na questão da verdade dos fatos. As vozes sociais da família, por um lado, e dos amigos de bar, por outro, se degladiam na arena da novela, mas não são jamais veridificadas pelo narrador. Este apenas apresenta as diversas vozes, dando a elas oportunidade de manifestação e de posição e expressando um momento particular de Jorge Amado em que "a comédia e a farsa substituem o drama e a tragédia” (SANT'ANNA, 2008, p.101). Nesta novela, ecos da picaresca, da malandragem, do realismo mágico e da sátira menipeia ${ }^{2}$ se imbricam para pro-

2 Por não caberem dentro dos limites deste ensaio, deixamos apenas apontadas as relações da novela que estamos a analisar com os gêneros citados: os ecos da picaresca se manifestam por conta da trajetória de vida da personagem principal, sua "pequena subida na vida" o aproxima de Lazarillo de Tormes, primeira personagem picaresca de que temos conhecimento. A malandragem aproxima Quincas Berro D’Água a Leonardo Pataca, personagem do romance Memórias de um Sargento de Milícias, do brasileiro Manuel Antonio de Almeida, já que os dois são tipos de certa personalidade brasileira, bem analisada por Antonio Candido em seu artigo Dialética da Malandragem. O realismo mágico, como afirma Sant'Anna (2008, p. 101) foi como que antecipada por Jorge Amado, já que a semelhança 
duzir uma narrativa plurivocal, em que as possibilidades convivem de forma aberta.

Dentro destas características elencadas até agora, somam-se quatro categorias que se inter-relacionam e que, em conjunto, constroem dão maior força à carnavalização. São elas a inversão, a excentricidade, a familiarização e a profanação. Tais categorias existem por conta de que as restrições, as leis e proibições, que sustentam o sistema e a ordem da vida comum revogam-se durante o carnaval: "revogam-se, antes de tudo, o sistema hierárquico de todas as formas conexas de medo, reverência, devoção, etiqueta etc.” (BAKHTIN, 1981, p.123). Assim, é por elas que o carnaval se sustém.

A inversão é marcada, principalmente, pela paródia. Esta é, por natureza, organicamente própria dos gêneros carnavalizados. Estranha aos gêneros puros, ela aciona a criação do "duplo destronante, do mesmo 'mundo às avessas'. Por isso a paródia é ambivalente.” (BAKHTIN, 1981, p. 127). Em Bakhtin, o conceito de paródia está agregado ao de carnavalização, posto que considera a festa do carnaval como o grau máximo de inversão em um processo cultural. Para ele, um

entre o brasileiro e o caribenho Gabriel Garcia Marques - maior nome do realismo mágico - é grande e visível. Por fim, a sátira menipeia, um dos gêneros carnavalescos, traz como tópico principal o chamado diálogo dos mortos. Além deste tópico, presente de forma magnifica na novela de Jorge Amado, a menipeia é um gênero flexível e mutável, capaz de penetrar outros gêneros e é um dos principais veículos e portadores da cosmovisão carnavalesca na literatura até nossos dias.

\section{4}


dos problemas mais complexos e interessantes da história da cultura é o problema do carnaval (no sentido de conjunto e todas as variadas festividades, ritos e formas de tipo carnavalesco), da sua essência, das suas raízes profundas na sociedade primitiva e no pensamento primitivo do homem, do seu desenvolvimento na sociedade de classes, de sua excepcional força vital e seu perene fascínio. Em sua ação principal, a coroação-destronamento, há um triunfo do "carnaval sobre a mudança” (BAKHTIN, 1981, p.107). É neste contexto que a paródia encontra-se com a cosmovisão carnavalesca e permite a configuração do mundo às avessas.

Em Amado, a paródia não acontece em nível narrativo, mas discursivo. No velório, os amigos Curió, Cabo Martim, Pé-de-Vento e Negro Pastinha assumem o lugar da família, sendo que Negro Pastinha chamada ao defunto de paizinho. Os amigos dão bebida para o morto, trocam suas roupas (apoderando-se do terno novo, sapatos e camisa, comprados pela família para honrar o falecido), e levam o corpo para comer moqueca. Esse processo de inversão faz com que a trama se desenvolva e dá a direção à narrativa. É por conta dele que a mesma se desenvolve.

A excentricidade está presente em cada linha da novela. A segunda morte desvela, por meio do riso e do deboche, que apesar de estar vestido como Joaquim, ele era Quincas já havia aderido a sua personalidade e Joaquim passou a ser sua triste fantasia. Para além desta excentricidade, o cômico é mesclado com a seriedade, já que para os amigos o 
velório é mais uma festa que um momento de luto. Por fim, a morte acontece no mar, local excêntrico, contrário aos objetivos da família. Estes queriam ver "Joaquim" enterrado num belo caixão, mas Quincas se joga ao mar e deixa o caixão a espera do corpo, demonstrando sua forma diferente de morrer e afirmando sua contrariedade à opinião da família.

As categorias carnavalescas de livre familiarização do ser humano foram transportadas para a literatura e contribuíram na destruição das distâncias épica e trágica, introduzindo assim no ramo literário a lógica das descidas profanadoras. A principal ação carnavalesca "é a coroação bufa e o posterior destronamento do rei do carnaval" (BAKHTIN, 1981, p.124), e é nessa ação ritual que reside a o núcleo da cosmovisão carnavalesca, a ênfase das mudanças e transformações, da morte e renovação. Tempo que tudo destrói e renova, expressa a alegre relatividade de qualquer regime ou ordem social. $\mathrm{Na}$ coroação, instaura-se a ideia de futuro destronamento. Em sua ação principal, este processo realiza um triunfo do carnaval sobre a mudança. Assim, a familiarização acontece com a figura de Joaquim, que é substituída por Quincas.

Por fim, a profanação se dá ao nível do discurso, no qual o narrador se posiciona positivamente e favor de Quincas e prefere sua posição à de Joaquim.

O palco das ações carnavalescas era a praça pública, pois sua ideia de público e universal permite que todos participem do contato que acaba por se tornar familiar. Esse carnaval público deixa de ser fonte imediata de carnavalização 
a partir do século XVII, cedendo lugar à influência da literatura carnavalizada; assim, "a carnavalização se torna tradição genuinamente literária." (BAKHTIN, 1981, p. 131). Assim, apesar de Quincas ser velado, ao inicio da narrativa, em seu quarto, a narrativa se desenvolverá pelas ruas de Salvador, ou, como prefere o narrador, da Bahia. O espaço destronante da rua dá voz ao subjugado Quincas e permite que este escolha sua morte e seu caixão, impedindo a imposição de imperar.

Assim, podemos dizer que o carnaval, no romance de Jorge Amado, é funcional. Ele não absolutiza nada, mas proclama a alegre relatividade de tudo; focaliza a ambivalência de cada imagem revelando sua biunivocalidade. $\mathrm{O}$ carnaval é uma grandiosa cosmovisão universalmente popular dos milênios passados. Ele opõe-se ao dogmatismo e à seriedade oficial unilateral e sombria, gerada pelo medo e hostil aos processos de mudança, tendente a absolutizar um dado estado da existência e do sistema social. Dessa forma, ao se valer de um discurso carnavalizado, Jorge Amado não abandona seu viés político, mas focaliza as mesmas questões por meio de pontos de vista diferentes. Assim, é possível a posição de Bakhtin ao afirmar que "quanto mais for o conhecimento das relações de gênero em um artista, tanto mais a fundo poderemos penetrar nas particularidades de sua forma de gênero e compreender mais corretamente a relação de reciprocidade entre a tradição e a novidade nessa forma" (1981, p. 159). Porquanto, além de perceber como se desloca o movimento de um determinado artista, percebemos que o mundo, quando visto pelo 
viés carnavalizado, vive em plena fronteira com seu contrário, permitindo assim uma forma nova e consciente de perceber a realidade.

\section{Referências}

AMADO, Jorge. A morte e a morte de Quincas berro D'água. São Paulo: Companhia das Letras, 2008.

BAKHTIN, Mikhail. A cultura popular na Idade média e no Renascimento. Trad. Yara Frateschi Vieira. 6. ed. Brasília/São Paulo: Ed. UNB/Hucitec, 2008.

- Problemas da poética de Dostoiévski. Trad. Paulo Bezerra. Rio de Janeiro: Forense-Universitária, 1981.

BOOTH, Wayne C. A retórica da ficção. Trad. Maria Teresa H. Guerreiro, Lisboa: Arcádia, 1980.

SANT'ANNA, Afonso Romano de. A vida e as vidas de Quincas Berro D’Água. Posfácio. In: AMADO, Jorge. A morte e a morte de Quincas berro D'água. São Paulo: Companhia das Letras, 2008, p.95-104. 


\section{(Re)Descobertas e Indefinições - entre a representação, a sub-representação, faroeste e orixás: uma breve leitura de Terras do sem fim, de Jorge Amado}

Auricélio Ferreira de Souza

\section{Resumo}

Este ensaio propõe uma leitura da obra Terras do sem fim, de Jorge Amado com o intuito de problematizar a questão da representação e da sub-representação social em seus personagens. Intenta-se, a partir de reflexões sobre a Teoria da Representação Social (TRS) sistematizada por Serge Moscovici, associada à crítica de Antônio Candido no que tange a relação literatura e sociedade, discutir o conjunto de implicações que a supervalorização da ideologia do autor traz para a sua escrita, repercutindo em uma compreensão peculiar da história sul baiana, do homem ali subalternizado e do próprio espaço que suporta todos esses.

Palavras-chave: Jorge Amado. Personagem. Representação. Sub-representação. Romance de 30. 


\section{Violência, jagunçagem, amores e sincretismos nas Terras do sem fim}

No fluxo de (re)descobertas e indefinições acerca da própria dimensão de regional propõe-se neste texto um exercício de leitura do romance Terras do Sem-Fim (1942) por acreditar que o mesmo reúne elementos convergentes para a ideia da diversidade representativa que se fortalece na literatura brasileira a partir da década de 30 , inclusive com toda a problemática inerente a esse conceito de diversidade.

Ambientada no Sul da Bahia, a história ocorre no início do século XX e em linhas gerais, trata da luta dos coronéis do cacau pela posse das terras devolutas daquela região. Contudo, os limites da obra se dilatam para muito além disso: o percurso utilizado para contar tal fato passa pela épica nos relatos da chegada dos trabalhadores no desbravamento da Mata de Sequeiro Grande, a colorida tipificação das prostitutas e aventureiros, pela truculência e austeridade dos coronéis, representantes de um interior selvagem e sustentado pela violência da força bruta, chegando a poeticidade de linguagem no trato dos dramas humanos dos explorados e violentados. Sobre essa obra o autor assim se posicionava no prefácio:

Há dez anos passados escrevi um romance, pequeno e violento; sobre o mesmo tema do cacau, ao qual volto hoje. Tinha eu então dezenove anos e iniciava minha vida de romancista. Nesses dez anos escrevi sete roman- 
ces, duas biografias, alguns poemas, centenas de artigos, dezenas de conferências.

Nesses dez anos lutei duramente, viajei, fiz discursos, vivi com meu povo a sua vida. Constato com imensa alegria que uma linha de unidade jamais quebrada liga não só toda a minha obra realizada nesses dez anos como a vida que durante eles vivi: a esperança - mais que esperança, certeza, de que o dia de amanhã será melhor e mais belo.

Em função desse amanhã, cuja madrugada já se levanta sobre a noite da guerra nos campos do este europeu, tenho vivido e escrito.

(AMADO, 1992)

O romance divide-se em seis partes: O Navio é a primeira, e trás o percurso de uma embarcação que parte da cidade da Bahia (atual Salvador), dirigindo-se para o sul, especificamente para Ilhéus, lócus do desbravamento da mata para a expansão do cacau. Nessa parte segue-se um quadro de descrições tanto da paisagem que ladeia o trajeto, de alguns dos protagonistas, bem como de suas expectativas. Comentários dão conta ainda das impressões acerca de outros habitantes 
das terras do sem-fim. Tem-se assim uma espécie de pré-anuncio do diverso painel que se desenvolverá adiante.

A segunda parte intitula-se $A$ Mata e a partir da descrição do temporal em uma mata de contornos assombrosos e gigantescos, principia a narração dos desbravadores avançando palmo a palmo na escuridão da noite na direção do "progresso". A ambientação parece objetivar a criação de efeitos fantasmagóricos que delineiem o impacto da aproximação do mítico, do desconhecido universo ancestral ali existente. Medo e violência marcam esses passos: a força do revólver em punho dá a Juca Badaró o poder de condutor desse empreendimento, que termina por obrigar os capangas supersticiosos a por a ordem na frente do medo. Lançando mão de uma movimentação típica da novela, divide espaço nesta parte, lances narrativos da casa do Coronel Horácio, suas posses, casos notórios vividos na tomada das terras, bem como martírios de sua esposa. Esse painel introdutório das duas famílias rivais - Horácio e Badarós - projeta a mata de Sequeiro Grande como a morada do sincrético: é o espaço onde habitam tanto os valores imemoriais (a natureza bravia e seus recursos quase ilimitados), a ancestralidade negra e cabocla, suas crenças e matrizes culturais, materializada na figura do feiticeiro Jeremias. Mas é também o marco possibilitador da expansão das terras que garantirão a riqueza através de cada nova muda de cacau plantada, ainda que regada por muito sangue.

Gestação de Cidades é a terceira parte, na qual ao longo de dez capítulos é narrado o processo de formação dos 
povoados no entorno da zona cacaueira de Ilhéus. Assim, do incipiente povoado de Tabocas, espécie de depósito de cacau seco, a narrativa conduz a um verdadeiro emaranhado, no qual progressivamente vão se entretocando dramas e histórias envolvendo rameiras, meia dúzia de advogados, dois médicos, escola, hospital, ruas enlameadas e o "fuxico" como demarcação de um modo de sociabilidade provinciano e atrasado. É digno de nota também o tom de extrema oralidade que se fortalece a partir desse ponto. Veja, por exemplo, o próprio início dessa parte quando a repetição da sentença: "Era uma vez três irmãs..." remete as estórias e "causos" do povo, passadas de boca em boca. As sentenças seguintes, num exercício cíclico, dão conta da sina de cada uma dessas três irmãs (Maria, Lúcia, Violeta) possível de ser resignificada em inocência, ascensão, e decadência.

Trapaça, manutenção das aparências, o desenho que começa a se fazer para a traição de Ester, subserviência da igreja, a negativa da escola enquanto espaço de civilidade e outras problemáticas da conturbada vida local, são lentamente tecidas no interior dessa terceira parte que, como a rítmica de um tambor, anuncia a insustentabilidade do clima trágico que se aproxima.

Em O Mar, quarta parte, ganha destaque a figura de capitão João Magalhães, que como único engenheiro (ainda que falso!) passa a ter papel relevante no conflito estabelecido naquela Ihéus: fazer a medição das terras. Essa função é desempenhada não por competência ou consciência do que 
ela implica, mas exclusivamente por ganância, tendo em vista os lucros que a mesma lhe aufeririam. É, portanto, um agente "indireto" ou inconsciente do momento alto do conflito. Acirram-se os relacionamentos: são narradas os rompimentos (Virgílio abandona Margot) as traições (Ester cede a atracão por Virgílio), e até os ainda possíveis "encantamentos líricos " (João Magalhães encanta-se com Don'Ana, que desperta para a primeira paixão). Os clãs rivais atacam-se ainda mais frequentemente. Encaminha-se o clímax do conflito.

Momento em que se constitui de fato o enfrentamento, a quinta parte, $A$ Luta, é o relato de como somam-se brutalidades e tocaias às artimanhas jurídicas nada ortodoxas de Badarós e Horácios na intrincada batalha pela terra. Essa questão, inclusive, repercute por todo o sul da Bahia, dando vulto a uma violência agora irrefreável. Cada lado do conflito se fortalece cada vez mais com jagunços, rifles papa-amarelo, facões e desejo de sangue. O relato segue e culmina com a supremacia de Horácio, que carregará junto com a vitória, um tanto de infelicidade como resultante. O preço do triunfo se incrustará nas memórias, posteriormente relatadas ao narrador.

Espécie de pós-relato, a sexta e última parte, O Progresso, traz o arremate do conflito: quem se assenta no poder após redesenhada a cena. Tabocas cresce, emancipando-se, o que permite a realização de um antigo pleito: mudar o nome para Itabuna. Ilhéus, na esteira das transformações, torna-se bispado. Về-se um Coronel Horácio às voltas com a formação de uma possivel oligarquia: elege, com o poder que tomara para si, deputado

\section{4}


federal (Doutor Jessé) e prefeito (Azevedo), apontando para um novo quadro no cenário político, que na verdade não se apresentam tão novo quanto se possa supor. Mortes à tocaia e a peleja pela terra, são agora lembranças de um passado rememorado. A mata tombara com sua ancestralidade, assim como o feiticeiro Jeremias. Os cacaueiros de agora, multiplicando-se e produzem "frutos estupendos", confirmando a fertilidade daquela terra, adubada com sangue.

Grotesco ou exagerado, como se vê nessas partes, o percurso se operacionaliza é pela tentativa do diverso e do amplo, tanto dos tipos quanto dos ambientes e tônicas que nele se desenrolam.

Isso posto, é possível perceber que esta obra pretende, seguindo o fluxo dos ideais libertários que influenciou a literatura de 30, "ir ao povo", mostrar o homem do interior, seus dilemas, misérias, virtudes e afetos. Era a ideia de um realismo literário como forma viável de não apenas retratar o regional, como nele construir plataforma de denúncia e transformação social:

Não nos pretendíamos modernistas, mas sim modernos: lutávamos por uma literatura brasileira que, sendo brasileira, tivesse um caráter universal; uma literatura inserida no momento histórico em que vivíamos e que se inspirava em nossa realidade, a fim de transformá-la.

(AMADO In RAILLARD, 1992, p. 36) 
Nesse romance, portanto, a mata de Sequeiro Grande, que é desbravada pelos conquistadores, torna-se mais que alvo das disputas entre os coronéis, ela é palco para uma diversidade na representação do homem, do lócus interior e do tempo que Amado tenta compor em seu texto. Assim, também, a família Badaró, cujo patriarca é Sinhô Badaró e a família de Horácio Silveira e sua esposa Éster, são índices possíveis a essa proposta de leitura. Cada uma dessas facções vai agregando ao seu torno outros coronéis, advogados e jagunços que mais do que aliados na guerra por terras, se apresentam como peças nesse vasto painel de diversidade representativa ou sub-representativa. A violência, talvez o principal fio condutor da trama, encontra vastas formas de representação. Ela é factual (tocaias, traições, espancamentos, mortes, expulsões, etc.), veja-se o caso de Firmo, que os Badarós decidem matar em tocaia por ter se negado a vender as terras pelo preço imposto, terras estas que garantiriam acesso natural a Sequeiro Grande e, consequentemente, garantiriam a expansão dos domínios. Mas é também violência simbólica, pois se por um lado os coronéis são postos com contornos bárbaros, de linguagem seca e objetiva, por outro a recorrência a lei ou ao abuso desta - estabelece uma dinâmica nova: o uso da palavra (ainda que sustentado em documentos falsos) num contexto expropriado de civilidade, com o intuito de subalternizar e silenciar o pobre, na figura dos pequenos proprietários. Aliás, a busca de representação do subalternizado é também uma constante nessa obra. Negro Damião, Negro 
Jeremias, Antonio Vitor, Raimunda, a prostituta Margot e até, Ester, que por seu percurso de órfã, romântica, sonhadora, casada à força com Coronel Horácio, é uma sem-voz. Em maior ou menor grau, eles apontam para aqueles que, vivendo numa cena social eminentemente violenta, não têm as condições para seguirem outro percurso senão aquele que as forças hegemônicas lhes apontam dentro deste contexto. Veja-se, por exemplo, o Negro Damião, jagunço do Sinhô Badaró, que, ao tempo em que é um assassino frio, é também um sujeito ingênuo, de gestos tolhidos, sociabilidade ou afetos abafados, não tendo um grande entendimento da extensão de seus atos criminosos e de sua subalternidade no jogo do poder.

Mais do que em outras obras igualmente ligadas a terra e conflitos, como Jubiabá (1935) ou Seara Vermelha (1946), Terras do sem fim agrupa personagens que trazem, a pesar de si e para além de si, uma vocalidade mais aberta - mas não necessariamente polifônica - ou seja, não parecem ser marionetes de forças mais poderosas que eles, como ocorre em Seara Vermetha. Ainda que pressionados ou subalternizados pela violência do contexto, mesmo sucumbindo à "lei do lugar", lei feita na base do fuzil papo-amarelo, o qual garante as terras e avia a morte no mítico interior baiano, nesse romance as personagens são mais "sincréticas" que nos outros, na medida em que possibilitam olhar em vários ângulos a dinâmica daquele conflito.

Mesmo apontando - segundo a crítica - flancos de fragilidade na composição psicológica das personagens, nesta obra é diverso o modo pelo qual tais personas experienciam 
aquilo que o jogo social vai progressivamente lhes impondo. Se não, vejamos: Ester, mulher fina, inteligente e culta, que falava francês, admirava e entendia música, não amando seu marido, Coronel Horácio (ex-tropeiro, que outrora vivenciara a subalternidade, empregado de roça no Rio-do-Braço, enriquecera plantando cacau e se embrutecendo na defesa das posses) vive em sofrimento e nos fornece uma visão de tédio, repulsa e desejo de distanciamento do conflito e de todo seu universo contextual. Ela não é um indivíduo talhado para aquele lócus, fato pelo qual se inquieta e anseia por outro modelo de vida. Doutor Virgílio, Margot e Capitão João Magalhães trazem para a trama a astúcia e perspicácia de um olhar de fora que, lançado sob o embate de forças ali instaurado, busca a possibilidade de lucro sem ceder a qualquer sensibilidade que se possa formar no que diz respeito aos inferiorizados, humilhados e massacrados à margem desse processo. A malandragem por eles enunciada (Virgílio vende "caxixes", documentos falsos; Margot usa o corpo como moeda de ascensão e Capitão João Magalhães vale-se da falsa condição de engenheiro, por meio de um anel de formatura (ganho no jogo de pôquer) não lhes insere, contudo, no grupo hegemônico do poder. $\mathrm{Na}$ verdade, servem a esse grupo e tentam se equilibrar individualmente nessa cena brutalizada. O feiticeiro Jeremias, como ícone organicamente ligado a mata do Sequeiro Grande, ativa uma memória ancestral do negro que vai chocar-se frontalmente com o anúncio do progresso que sub-julga o valor do natural, do anímico, manifesto em sua ação altruísta de ajudar 
aos que estão ao seu redor, curando e aconselhando-os. Diferente de Damião, Jeremias não se deixa subalternizar, mantém resquícios da memória coletiva negra, defende a mata, condena a ação predatória ali estabelecida e morre por conta desse conflito.

Citando apenas estes personagens dentre os vários que compõem a trama, é possível perceber como em termos de disposição das "peças" a estrutura é fortemente voltada para a composição de uma diversidade.

Esse aspecto é exemplificado já no início da obra na construção da cena em que um navio que transporta trabalhadores e coronéis à região cacaueira, fornecendo uma espécie de panorama antecipador dos tipos que atuarão, como protagonistas ou como meras peças, no intrincado jogo pelo poder. No navio estão dispostos os chefes locais na primeira classe, os caixeiros-viajantes, jogadores e prostitutas na segunda, e por fim, trabalhadores migrantes, socialmente silenciados, mas animados pelos sonhos de enriquecimento, amontoados na terceira classe. Essa busca por arquitetar diversidades por vezes não é considerada pelos críticos que, vêm nela mais um painel de colorido exagerado do que uma base de fato polifônica. Para tanto argumentam que, não apenas no romance em questão, mas em grande parte de sua obra, Jorge Amado [...] adotou uma fórmula populista, criando uma imagem de Brasil mulato onde as relações se resolvem por meio da ginga, mas que no fun- 
do mascara todas as contradições da realidade, diz o crítico Alcir Pécora. (PÉCORA)

[...] Mário de Andrade o criticava por ser caudaloso, mas pouco esforçado em seu texto. De uma forma geral, os modernistas entendiam sua obra como um retrocesso, já que não promovia inovações de linguagem e não se abria a várias interpretações.

(ANDRADE)

Ou ainda que Ele retomou o folhetim romântico do século 19. "Mas conseguiu arrastar multidões com isso e criou público para o romance brasileiro", diz Eduardo de Assis Duarte. (BORTOLOTI, 2011, p. 9).

Na obra em questão, se o desejo de Amado foi pelo viés da ficção propor um panorama do que o mandonismo e violência do coronelismo cacaueiro criou no sul baiano, muito disso parece escapar à crítica, para a qual tanto São Jorge dos Ilhéus (1944) quanto Terra dos sem fim (1942) se valem de uma concepção de história claramente "etapista", além de mostrar um efeito de desencaixe entre os personagens e sua função histórica. Mas porque em tão longo período a crítica literária parece estar empenhada em apontar nos romances desse autor mecanismos que desautorizem sua inclusão na categoria de obras relevantes na construção da nova literatura 
brasileira? Estaríamos diante apenas de uma situação de má vontade? De uma interpretação contextual que supervaloriza apenas o fato de sua ampla penetração popular?

Alguns dos pontos apresentados como negativa a essa literatura merecem ser considerados amiúde para que possamos compreender melhor essa recusa. A tentativa de dar ao homem regional contornos universais, é, na visão da crítica, operação que compromete a profundidade psicológica das personagens, posto que a ideologia política de Amado é, ela própria, já comprometida com uma ideia de "universal" fortemente ligada aos preceitos socialistas/comunistas. A dedicatória à Dmitri Shostakovich, compositor e soldado de Leningrado em Terra dos sem fim, seria um claro indicador dessa ligação.

A frase inicial: $O$ apito do navio era como um lamento $e$ corton o crepúsculo que cobria a cidade e o trecho que a segue, no qual é descrito a chegada do navio (símbolo do progresso e da transformação) na cidade interiorana - de "casario de construção antiga" com seus "telhados negros, ruas calçadas de pedras enormes" por onde não passava ninguém - (portanto, símbolo do atraso e de um modelo de sociabilidade opressor e asfixiante) igualmente pode ser utilizado para argumentar quanto ao endereçamento da ideia de interior oprimido e metrópole opressora.

Em oposição a essa interpretação da crítica, escritores, artistas e intelectuais que defendem a obra de Amado afirmam que sua grande criatividade na composição do vasto 
elenco de tipos, muitos incorporados ao imaginário brasileiro, sobretudo baiano, resulta da sua capacidade de escuta do repertório das estórias orais desse povo, conferindo-lhe vasta penetração popular e que tal fenômeno, portanto, "libera" sua obra da profundidade psicológica que a crítica espera no romance de 30. O livro pode ter densidade psicológica e ser um péssimo romance. Jorge Amado permitiu que muitos leitores gostassem de literatura e se reconciliassem com os temas nacionais, diz o escritor João Ubaldo Ribeiro (In BORTOLOTI, op.cit., p.9). O argumento seria, portanto, o de que o apelo popular ocorre porque há identificação com o povo, que não apenas se vê representado nessa obra, como aprova tal representação, fator que se reflete na alta e constante vendagem dos títulos do autor, amplamente reeditado e traduzido.

Contudo, para confrontar tal argumento é preciso lembrar que tratar recorrentemente o povo e suas temáticas, não necessariamente significa representar esse povo no que tange a não apenas "pintá-lo", mas fazer com que sua voz (antes conflituosa que uníssona) encontre mecanismos de fluxo no eixo da literatura proposta, afinal as teorizações acerca da representação via arte, apontam para uma problemática mais profunda do que a mera expressão sucitadora do interesse "turístico" pelo pitoresco do(no) regional.

Arruda (2002), pensado as bases da Teoria das Representações a partir da obra fundante $A$ Psicanálise, sua imagem e seu público, de 1961 na qual Serge Moscovici busca, por meio das contribuições da sociologia de Durkheim, sistemati- 
zar na psicologia social uma teorização sobre a representação social, nos ajuda a perceber o peso que o representar ou o sub-representar exerce na obra artística. Certamente tal peso é que se constituirá como elemento diferenciador em termos de diversidade na literatura feita no Brasil antes e depois de 30, como já vimos, década esta extremamente convulsiva no cenário nacional.

Sobre as contribuições dessa teoria, assim se posiciona Arruda (2002, p.129):

A Teoria das Representações Sociais (TRS) operacionalizava um conceito para trabalhar com o pensamento social em sua dinâmica e em sua diversidade. Partia da premissa de que existem formas diferentes de conhecer e de se comunicar, guiadas por objetivos diferentes, formas que são móveis, e define duas delas, pregnantes nas nossas sociedades: a consensual e a científica, cada uma gerando seu próprio universo. A diferença, no caso, não significa hierarquia nem isolamento entre elas, apenas propósitos diversos. O universo consensual seria aquele que se constitui principalmente na conversação informal, na 
vida cotidiana, enquanto o universo reificado se cristaliza no espaço científico, com seus cânones de linguagem e sua hierarquia interna. Ambas, portanto, apesar de terem propósitos diferentes, são eficazes e indispensáveis para a vida humana. As representações sociais constroem-se mais freqüentemente na esfera consensual, embora as duas esferas não sejam totalmente estanques. (grifos do autor).

Desse quadro depreende-se que

[...] no universo consensual aparentemente não há fronteiras, todos podem falar de tudo, enquanto no retificado só falam os especialistas. De acordo com ele, seríamos todos "sábios amadores", capazes de opinar sobre qualquer assunto numa mesa de bar, diferentemente do que ocorre nos meios científicos, nos quais a especialidade determina quem pode falar sobre o quê. Arruda.

(ARRUDA, p.130) 
Isso posto, pensando o romance em questão, podemos dizer que tanto há a representação consensual, na medida em que o canônico cede ao popular (o homem interiorano, sua geografia, história, linguagem, costumes e agruras) quanto, dentro desse, um certo exagero que tende a sub-representação, entendendo esse termo como o fenômeno pelo qual um elemento é posto na representação, mas não operacionaliza a função que dele se espera. Seria um ícone impotente de sua mais primordial condição: possibilitar uma fixação ideológica. As razões para a incidência deste fato na obra em questão, devese, talvez, como já afirmara Candido (op.cit. 2006, p.131), por certa "preponderância do problema sobre o personagem." A necessidade de trazer um fato esquecido ou perdido - no caso, a história do sul baiano - por meio de uma mnemônica ficcional parece, nesse caso, ser posto em maior valorização em detrimento aos personagens que operacionalizarão tal ação, o que lhes confere uma rasa psicologia e, como consequência disso, um silenciamento de sua potência icônica.

Numa perspectiva semelhante, Moscovici (2007, p.58) nos lembra que:

As representações que nós fabricamos duma teoria científica, de uma nação, de um objeto, etc. - são sempre o resultado de um esforço constante de tornar real algo que é incomum (não-familiar), ou que nos dá um sentimento de não-familiaridade. E através delas nós superamos o problema e o inte- 
gramos em nosso mundo mental e físico, que é, com isso, enriquecido e transformado. Depois de uma série de ajustamentos, o que estava longe, parece ao alcance de nossa mão; o que era abstrato torna-se concreto e quase normal $[\ldots]$ as imagens e ideias com as quais nós compreendemos o não-usual apenas trazem-nos de volta ao que nós já conhecíamos e com o qual já estávamos familiarizados.

(MOSCOVICI, 2007, p.58)

Diante disso, em Amado, e em particular no romance em questão, é possível que a nítida influência que os ideais comunistas de luta contra as injustiças, garantia coletiva de direitos, dentre esses a questão da terra e de modelos produtivos sustentáveis nela empreendidos, tenham sido transpostos para o romance, alterando consideravelmente as principais matizes do contexto cacaueiro, a saber: o homem, o lócus de sua vivência e, consequentemente, os mecanismos pelos quais ambos se entre - tocam e se transformam. O desejo, pois, de um homem universal, imerso numa contextualidade igualmente universal: a da exploração que precisa ser combatida a todo custo, como "[...] madrugada que já se levanta sobre a noite da guerra nos campos do este europeu [...]" para usar as próprias palavras do autor, contidas no prefácio da obra em tela, termina por, inversamente, resultar num homem, numa 
terra e num embate, muito mais alinhado com o ideário que o autor esperava, do que com a densidade efetivamente representante da sociedade que suporta a trama.

Sobre esse aspecto, em oportunidade na qual se referia a problemática na literatura de Jorge Amado, Antonio Cândido afirma: "nesses romances há um intuito ideológico ostensivo demais, que, por não ser incorporado como elemento necessário à composição, parece com frequência superposição indigerida" $"$.

\section{O feiticeiro Jeremias, a catarse da raça}

Já vai adiantada certa vertente da análise e da crítica literária que tem procurado voltar-se para personagens ditas "secundárias" defendendo que, perquiridas com o instrumental adequado, revelam novas e profundas dimensões do texto. Ocupando geralmente uma posição de subalternidade, essas personagens ao passo que silenciadas e negligenciadas pelo plano da ação central, podem, por isso mesmo, estar impregnadas de possibilidades em aberto, no que tange a pontos de vista plurivalentes tanto dessa ação quanto, e, inclusive, do plano de sua criação. Funcionam como testemunhas comportadas, mas potentes em linguagem, posto que, não tendo lugar de destaque na cena (o centro do palco), lhes sobra a tangente

1 In Enciclopédia On-Line de Literatura Brasileira do Itaú Cultural. Verbete Amado, Jorge (1912 - 2001). Disponível em: http:/ / www.itaucultural. org.br/aplicexternas/enciclopedia_lit/index.cfm?fuseaction=biografias_ texto\&cd_verbete=12265\&cd_item=226 Acesso: 09/10/2012. 
de todos os outros ângulos.

Considerando essa perspectiva, a partir desse ponto do texto propõe-se um exercício de leitura sobre a personagem Jeremias, de Terra do sem fim. O intuito é investigar como pesando sobre ele caracteres como a negritude, a velhice, o isolamento e o resguardo da tradição ancestral, este compreende o jogo de poder que se estreita no entorno de Sequeiro Grande e, como se posiciona a partir de tal compreensão.

Se formos contabilizar veremos que o feiticeiro Jeremias não tem uma numerosa aparição na obra, e que, somado ao fato de ser negro, pobre e velho, não tendo, portanto voz de mando no conflito, tão pouco interessando aos coronéis como força de combate, o torna "secundário" na trama. Contudo, a ideia central que resume o conflito entre Badarós e Horácios: a terra adubada com sangue é plenamente compreendida por ele no seu momento clímax, mesmo em face da precariedade de seu modus operandi.

Jeremias se ergue. Desta vez não precisou de bordão para sustentar em pé seu corpo centenário. Deu dois passos para a porta da cabana. Agora seus olhos quase cegos viam perfeitamente vista a mata em todo seu esplendor. E a via desde os dias mais longínquos do passado até esta noite que marcava o seu fim.

(AMADO, 1970, p.123) 
Mais que isso, a cena em que se dá a "praga ardente" por ele lançada sobre os invasores da mata, evidencia que o mesmo, ainda que silenciado, tem uma ativa consciência do processo predatório que se anuncia como irreversível.

[...] Sabia que os homens a iam penetrar, iam derrubar a floresta, matar os animais, plantar cacau na terra onde havia sido a mata de Sequeiro Grande. Enxergou o fogo das queimadas se estorcendo nos cipós, lambendo os troncos, ouviu o miado das onças acossadas, o guincho dos macacos, o silvo das cobras se queimando. Viu os homens de machado e facões acabando com o resto que o fogo deixara, pelando tudo, pondo a terra nua, arrancando até as raízes mais profundas dos troncos.

(Ibid., p.123-124)

Talvez essa consciência seja a mais acessa de todos os envolvidos, ao ponto de que, justamente por isso, se converta numa verbalização tão arrebatadora, impossível de ser vertida por outra personagem. A palavra de Jeremias queima antes que o fogo factual chegue à mata.

As palavras de Jeremias eram para os 
seus deuses, os deuses que tinham vindo das florestas da África, Ogum, Oxossi, Iansã, Oxolufã, Omolu, e também a Exu, que é o diabo. Clamava por eles para que desencadeassem a sua cólera sobre aqueles que iam perturbar a paz da sua moradia.

(Ibid., p.124)

É ele, Jeremias, a ancestralidade até então amordaçada e posta fora do ângulo central, que vocifera agora a memória acesa em palavra contra os que, já avançando naquele anímico espaço, sedentos pelo poder, conhecerão a fatídica sina dos gananciosos: ser soterrados pelos escombros de sua própria barbárie. E, por fim, sua cólera verte-se em um fluxo:

- O olho da piedade secou e eles tá olhando pra mata com o olho da ruindade.[...] Agora eles vai entrar na mata mas antes vai morrer homem e mulher, os menino e até os bicho de pena. Vai morrer até não ter mais buraco onde enterrar, até os urubu não dar mais abasto de tanta carniça, até a terra tá vermelha de sangue que vire rio nas estrada e nele se afogue os parente, os vizinho e as amizade deles, sem faltar nenhum. Vão entrar 
na mata mas é pisando carne de gente, pisando defunto. Cada pé de pau que eles derrube vai ser um homem derrubado, e os urubu vai ser tanto que vai esconder o sol. Carne vai ser estrume de pé de cacau, cada muda vai ser regada com sangue deles, deles tudo, tudo, sem faltar nenhum.

(Ibid., p.124)

O cacau é o começo, mas também é anunciado pelo feiticeiro como sendo o fim: - Cada filho vai plantar seu cacaneiro em riba do sangue do pai (...)

Jeremias, tendo consciência de que seu fim antecipa o da mata, e de que a organicidade com a aquela natureza rompera-se, leva a exaustão o seu fluxo como se a palavra esvaziasse de seu corpo longevo e gasto, o último sopro anímico. "[...] Seu corpo foi cedendo, tinha sido imenso o esforço. Foi cedendo, seus olhos cegaram de todo, as pernas se dobraram e ele caiu sobre a terra, os pés tocaram no negro Damião transido de medo." (AMADO, 1970, p.124).

Esse rompimento já não deixa dúvida: o feiticeiro cumprira sua potência de linguagem, dissera-se, literalmente, até o auto-aniquilamento, compreendendo que seu sentido prendia-se organicamente ao sentido da mata de Sequeiro Grande. Se quanto ao futuro nada pode fazer, posto que velho e inapto ao combate, quanto ao presente ele se cumpre: realiza a catarse 
possível ao negro criado nos limites da obra em questão.

\section{Conclusão}

Corroborando a tese de Lukács de que "a vida faz-se criação literária", e pelo que o romance agregou ao curso de seu desenvolvimento, espera-se que este possibilite, por meio de exercício da leitura, "[...] descobrir e construir, pela forma, a totalidade oculta da vida" (LUKÁCS 2009, p.60). Totalidade esta, que em face das novas demandas e configurações da experiência humana, necessita obrigatoriamente promover o caráter aberto, polifônico desse homem e de seus modus de experienciar, seja a construção ou a destruição, o amor ou a dor, os afetos e suas diferentes matizes, já que se esclerosara a epopéia e sua totalidade fechada. De tal modo, essa compreensão só pode advir da proficiente arregimantação de certos ativadores da tessitura vida x criação literária, em especial entre estes, acreditamos estar o processo de representação do lócus, do evento e, principalmente, das personas criadas para dar sustento às ações que edificarão a obra pretendida.

Assim, acreditamos que só há de fato obra se a proposta lançada alude, ou mais: ativa, uma experiência identificável no plano da vida sócio-históricamente reconhecível pelos receptores de tal proposta. Equivale dizer que a "totalidade oculta da vida” de que nos fala Lukács, não pode ocorrer se não por esta representação, posto que segundo o pensamento lukácsiano “[...] o homem torna-se ao mesmo tempo o escritor de sua própria vida e o observador dessa vida como uma obra de arte criada". 
Nessa duplicidade em que se coloca em relação à obra literária, tanto autor, quanto receptores, sabem que a personagem não é ícone de si, imagem "turística" autoreferenciada, mas eco de muitos sentidos possíveis, ou ainda em vias de tessitura na obra e para além dela, pois convertem-se em perpétua busca, conforme nos lembra Lukács:

[...] a busca é apenas a expressão, da perspectiva do sujeito, de que tanto a totalidade objetiva da vida quanto sua relação com os sujeitos nada têm em si de espontanemente harmonioso - aponta para a intenção da configuração: todos os abismos e fissuras inerentes à situação histórica têm de ser incorporados à configuração e não podem nem devem ser encobertos por meios composicionais. Assim, a intenção fundamental determinante da forma do romance objetiva-se como psicologia dos heróis romanescos: eles buscam algo. (os grifos são meus)

(LUKÁCS 2009, p.60)

Nesse trabalho, em que propusemos um breve exercício de leitura sobre o romance de Jorge Amado, pensamos que essa problematização quanto a certos procedimentos ou meios 
composicionais largamente utilizados pelo autor, como a "alegorização" — no sentido carnavalesco do termo — , das personagens em detrimento ao processo de representação social, gera profícuos pontos de reflexão sobre o já acalorado debate em torno do conjunto da obra de Amado. Tais pontos, contudo, a nosso ver, não devem ser encaminhados na direção de auferir ou subtrair qualidade artística ao texto, mas sim na de fortalecer a instrumentalização das análises e da crítica acerca do que esses processos têm a nos revelar sobre o romance brasileiro de 30 e, em especial, sobre as formas de subalternização que o mesmo pioneiramente discutiu e que podem ser (re) descobertas ou (re) definidas a partir de um olhar mais atencioso para as chamadas personagens secundárias.

\section{Referências}

AMADO. Terras do sem fim. 27. ed. São Paulo: Martins, 1970.

In RAILLARD, Alice. Conversando com

Jorge Amado. Rio de Janeiro: Record, 1992, p.36.

ARRUDA, Ângela. Teoria das representações sociais e Teorias de gênero In Cadernos de Pesquisa, n. 117, p 127-147 nov. 2002. Universidade Federal do Rio de Janeiro.

BORTOLOTI, Marcelo. Primeira obra de Jorge Amado 
completa 80 anos. São Paulo: Folha de São Paulo, 9 abr. 2011.

BOSI, Alfredo. História concisa da literatura brasileira. 39. ed. São Paulo: Cultrix, 1994.

CANDIDO, Antônio. Literatura e Sociedade. Rio de Janeiro: Ouro sobre azul, 2006.

LUKÁCS, G. A teoria do romance: um ensaio histórico-filosófico sobre as formas da grande épica. 2.ed. São Paulo: Duas Cidades; Editora 34, 2009.

MOSCOVICI, S. Representações sociais: investigações em psicologia social. Rio de Janeiro: Vozes, 2003. 


\section{Os Autores}

Auricélio Ferreira de Souza Mestrando em Literatura e Inerculturalidade pelo Programa de Pós-Graduação - PPGLI da Universidade Estadual da Paraíba - UEPB. Atualmente é professor no Dept ${ }^{\circ}$ de Línguas e Literatura da Universidade Regional do Cariri (URCA).

Cid Seixas Fraga Filho Doutor em Letras (Literatura Portuguesa) pela Universidade de São Paulo. Foi professor Titular do curso de Letras da Universidade Federal da Bahia- UFBA. É ainda coordenador dos cursos de pós-graduação lato sensu do CEDAP em parceria com a Faculdade São Luís de França. Pesquisador e autor de renome que pessoalmente conheceu Jorge Amado.

Ediliane Letite de Figueredo Mestre em Literatura e Interculturalidade e doutoranda em Literatura e Interculturalidade pelo PPGLI - UEPB. Atualmente é professora de Hermenêutica Jurídica e Direitos Humanos na Faculdade Maurício de Nassau.

Geralda Medeiros Nóbrega doutorado em Letras pela Universidade Federal da Paraíba e pós-doutorado pela Universidade Federal de Pernambuco. Foi professora do curso de Letras da Universidade Federal da Paraíba (UFPB), e da Universidade Estadual da Paraíba. Hoje atua na pós-gradu- 
ação, colaborando como professora voluntaria do mestrado e doutorado em Literatura e Interculturalidade da UEPB. Pesquisadora e autora de renome com livros e artigos publicados sobre Literatura Brasileira.

Humberto Luiz Lima de Oliveira Doutor em Literatura Comparada, é pesquisador, tradutor e Professor Adjunto da Universidade Estadual de Feira de Santana. Trabalha na área da Literatura Comparada e francófona. Pesquisador e autor dos livros e artigos publicados em português e francês.

Lilian Barbosa Mestre em Letras. É professora de língua espanhola na Universidade Estadual da Paraíba. Atua nas áreas de Língua e Literatura Espanhola, Literatura Comparada e Literatura Hispano-americana.

Lucira Freire Monteiro Doutora em Direito, Justiça e Cidadania pela Universidade de Coimbra - Portugal. Professora do Departamento de Direito Privado do Centro de Ciências Jurídicas da Universidade Estadual da Paraíba.

Luis Felipe de Q. A. Leite Doutorando em Literatura e Interculturalidade da Universidade Estadual da Paraíba. Mestre em Ciências Sociais pela Universidade Federal da Bahia. Bacharel em Crítica Literária pela Universidade Federal de Pernambuco. Professor de Literatura do curso de Licen- 
ciatura em Letras da Faculdade São Miguel em Recife e do Colégio Divino Mestre em Jaboatão dos Guararapes.

Maria Divanira de Lima Arcoverde é doutoranda do Programa de Pós-Graduação em Literatura e Interculturalidade da Universidade Estadual da Paraíba - PPGLI/UEPB. Mestra em Ciências da Sociedade, na área de concentração "Linguagens e Cultura" - PPG/UEPB. Coordena o Curso de Letras/EAD/UAB/UEPB com publicação em conteúdo de Leitura e Produção Textual.

Marilene do Carlos Vale Melo Mestra e doutora em Letras pela Universidade Federal da Paraíba. Atualmente é professor da Universidade Estadual da Paraíba. Tem experiência na área de Letras, com ênfase em Literatura Brasileira, literatura infanto-juvenil e Filologia Românica.

Nefatalin Gonçalves Neto Mestra em Literatura Portuguesa pela USP com formação em latim. Atualmente é professor de latim e de língua portuguesa UFRPE, unidade acadêmica de Serra Talhada, realiza pesquisas na área de literatura, duplicidade e fragmentação do sujeito narrativo.

Patrícia Gomes Germano Mestra em Literatura e Interculturalidade e doutoranda PPGLI - UEPB - CAPES/ CNPQ, com pesquisa na área de tradução intersemiótica dos textos amadianos, é professora da Rede Pública Esta- 
dual da Paraíba. No âmbito profissional, atuou como Secretária Adjunta de Educação do município de Aroeiras, como professora na FURNE/UNIPÊ, além de professora da rede pública municipal e estadual de ensino.

Sueli Meira Liebig Doutora em Letras pela Universidade Federal de Minas Gerais/Universidade da Georgia, EUA (2002), na área de Literatura Comparada; Mestra em Literatura Anglo-americana pela UFPB (1992). Atualmente é professora do graduação e do mestrado em Literatura e Interculturalidade da Universidade Estadual da Paraíba. Tem publicado artigos em diversos periódicos nacionais e internacionais.

Sudha Swarnakar Ph. D. em Comparative Theory pela Warwick University, Inglaterra (1998). Mestra em Lingua e Literatura Hindi pela Indore University (1967), Índia e Mestra em Lingua Inglesa pela UFPB (1985). Atualmente é professora da graduação e do mestrado e doutorado em Literatura e Interculturalidade da UEPB. Tem publicado livros e artigos em diversos periódicos nacionais e internacionais. E poliglota e trabalha com literaturas de diversas línguas. 
Esta coletânea de ensaios críticos apresenta nova fortuna crítica deste grande escritor que discute temas ainda inexplorados. Estes artigos são escritos tanto pelos estudiosos amadianos de renome quanto pelos jovens que estreiam suas carreiras de críticos, críticos emergentes que sentiram a necessidade de oferecer uma nova leitura deste escritor controverso nesta ocasião de centenário. Cobrindo um vasto campo: literatura, linguística, história, memória e direito. Esses escritores estão apresentando suas críticas das obras amadianas para chamar a atenção, para desmistificar o mito em torno de Amado e também para provocar o leitor a reler obras de Amado no novo século com uma nova perspectiva.

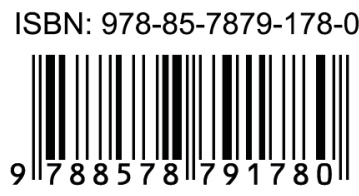

\section{\&eduepb}

